Uniwersytet Przyrodniczy w Lublinie

\title{
Zagrożenia środowiska i bezpieczeństwo żywności
}

Tom 1

Środowisko - Roślina - Zwierzę - Produkt 
Zagrożenia środowiska

i bezpieczeństwo żywności

Tom 1 
Środowisko - Roślina - Zwierzę - Produkt 


\section{Zagrożenia środowiska i bezpieczeństwo żywności}

Tom 1

pod redakcją

Bożeny Nowakowicz-Dębek

Witolda Chabuza

Lublin 2020 
Recenzenci

prof. dr hab. Robert Kupczyński

dr hab. inż. Beata Seremak, prof. ZUT

Opracowanie redakcyjne

Ewa Zawadzka-Mazurek

Projekt okładki

Jacek Pałyszka

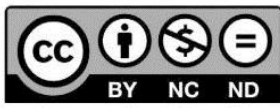

Ten utwór jest dostępny na licencji Creative Commons Uznanie autorstwa Użycie niekomercyjne - Bez utworów zależnych 4.0 Międzynarodowe.

\title{
ISBN 978-83-7259-329-0 on-line
}

DOI: $10.24326 /$ mon. 2020.8

\author{
IVIOTR \\ Wydawnictwo Uniwersytetu Przyrodniczego w Lublinie \\ ul. Akademicka 15, 20-950 Lublin \\ www.wydawnictwo.up.lublin.pl \\ 8,7 ark. wyd.
}




\section{Spis treści}

Artur Niedzielski, Monika Szymczuk, Jakub Kalinowski, Lukasz Kozian,

Amelia Kowal, Kinga Kropiwiec-Domańska, Anna Kasprzyk, Marek Babicz

Czynniki wyboru przez konsumentów mięsa wieprzowego oraz wędlin podrobowych ......

Factors of choice of pork and offal sausages by consumers

Joanna Jędrusyna, Aleksandra Krochmal, Anna Teter,

Monika Kędzierska-Matysek

Jakość mlecznych produktów fermentowanych wyróżnionych znakiem

„Jakość Tradycja”

Quality of fermented milk products with the "Quality Tradition" label

Joanna Jędrusyna, Karolina Król, Magdalena Stobiecka, Aleksandra Krochmal,

Barbara Topyla

Zmiany jakości mleka spożywczego podczas przechowywania

Changes in the quality of drinking milk during storage

Aleksandra Krochmal, Joanna Jędrusyna, Patrycja Dopieralska,

Magdalena Stobiecka, Anna Teter, Monika Kędzierska-Matysek

Jakość serów twarogowych o zróżnicowanej zawartości tłuszczu

Quality of tvarog cheeses with different fat content

Lukasz Kozian, Paulina Kochanek, Jakub Kalinowski, Monika Szymczuk, Damian Zarajczyk, Marian Flis, Kinga Kropiwiec-Domańska, Marek Babicz

Wpływ upraw rolnych na biologię dzików

The influence of agricultural crops on the biology of wild boars

Jan Zdulski, Witold Chabuz, Wioletta Sawicka-Zugaj, Aneta Krawiec,

Karol Szulc, Magdalena Stobiecka

Wypas pastwiskowy jako czynna forma ochrony przyrody

Pasture grazing as an active form of nature protection

Wojciech Ospalek, Wiktoria Polit, Nina Mickiewicz, Agata Satowska,

Agata Domagała, Lukasz Wlazło, Bożena Nowakowicz-Dębek

Wpływ długości fal świetlnych na rozwój mikroorganizmów

The impact of wavelengths of light on the growth of microorganisms

Martyna Kasela, Agnieszka Grzegorczyk, Mateusz Ossowski,

Bożena Nowakowicz-Dębek, Anna Malm

Personel domu pomocy społecznej jako rezerwuar metycylinoopornych szczepów Staphylococcus sureus

Nursing home personnel as a reservoir of methicillin-resistant strains

of Staphylococcus aureus

Katarzyna Karpińska, Damian Jaguszewski, Mateusz Ossowski, Martyna Kasela,

Bożena Nowakowicz-Dębek

Skuteczność dezynfekcji telefonów komórkowych z wykorzystaniem

komercyjnych chusteczek antybakteryjnych

The effectiveness of disinfecting mobile phones with the use of commercial

antibacterial wipes 


\section{Anita Gorczyca, Antonina Krawczyk}

Charakterystyka SARS-COV-2 na tle pozostałych koronawirusów

Characteristics of SARS-CoV-2 compared to other coronaviruses

Damian Jaguszewski, Katarzyna Karpińska, Mateusz Ossowski, Martyna Kasela, Lukasz Wlazlo

Natężenie owietlenia w środowisku pracy nauczyciela zatrudnionego w szkole podstawowej

Illumination intensity in the work environment of a teacher employed in a primary school

Damian Zarębski, Szymon Chmielewski, Adam Gawryluk, Ilona Woźniak-Kostecka

Projekt lokalizacji ogniw fotowoltaicznych

na wybranych budynkach miasta Lubartów

Project of the location photovoltaic cells on selected buildings in the Lubartów city 
Artur Niedzielski ${ }^{1,3}$, Monika Szymczuk ${ }^{1}$, Jakub Kalinowski, Łukasz Kozian ${ }^{1}$, Amelia Kowal ${ }^{1}$, Kinga Kropiwiec-Domańska ${ }^{2}$, Anna Kasprzyk ${ }^{2}$, Marek Babicz ${ }^{2}$

\section{Czynniki wyboru przez konsumentów mięsa wieprzowego oraz wędlin podrobowych}

Factors of choice of pork and offal sausages by consumers

Mięso i podroby wieprzowe w Polsce są bardzo ważnym elementem jadłospisu ze względu na tradycje i zwyczaje żywieniowe. W 2018 r. ilość spożywanej wieprzowiny wyniosła 40,0 kg na mieszkańca, tj. o $10,39 \%$ więcej niż w 2017 r. [KOWR 2019]. Natomiast konsumpcja podrobów kształtowała się na poziomie 4,5 kg [GUS 2018]. Przypuszcza się, iż jest to spowodowane większą siłą nabywczą konsumentów, jak też traktowaniem wieprzowiny jako stosunkowo taniego źródła białka. Nie bez znaczenia są też walory kulinarne i sensoryczne mięsa $\mathrm{i}$ jego przetworów.

Trzoda chlewna jest użytkowana jednostronnie, będąc źródłem surowca rzeźnego. $Z$ tuszy wieprzowej pozyskiwane są elementy zasadnicze, spośród których najcenniejsze to: schab, szynka, łopatka, karkówka i boczek. Oprócz nich uzyskuje się jadalne uboczne surowce rzeźne, w tym podroby. Do podrobów wieprzowych zalicza się: nerki, śledzionę, mózg oraz ośrodek, tzw. zespół naturalnie ze sobą połączonych lub rozdzielonych elementów, w którego skład wchodzą: język, serce, wątroba, płuca z przełykiem, krtanią i tchawicą oraz ścięgnami przepony brzusznej [PN-65/A-82000, PN-86/A-82004].

Aktualnie w Polsce hodowanych jest 8 ras świń: wielka biała polska (wbp), polska biała zwisłoucha (pbz), puławska, złotnicka biała, złotnicka pstra, duroc, hampshire oraz pietrain. Każda z nich charakteryzuje się określonym poziomem cech rzeźnych, bardziej lub mniej preferowanych przez konsumentów [Tyra 2013]. Jak wynika z danych uzyskanych z oceny przyżyciowej (tab. 1) rasa świń wpływa na zawartość mięsa i tłuszczu w tuszy, co z kolei decyduje o możliwości jej wykorzystania w produkcji mięsa kulinarnego i wędlin.

\footnotetext{
${ }^{1}$ Studenckie Koło Naukowe Nauk o Zwierzętach i Bioekonomii Sekcja Hodowli i Biotechnologii Świń, Uniwersytet Przyrodniczy w Lublinie

${ }^{2}$ Instytut Hodowli Zwierząt i Ochrony Bioróżnorodności, Zakład Hodowli i Biotechnologii Świń, Wydział Nauk o Zwierzętach i Biogospodarki, Uniwersytet Przyrodniczy w Lublinie

3 e-mail: niedzielskiartek@gmail.com
} 
Tabela 1. Wyniki oceny przyżyciowej knurków i loszek hodowlanych poszczególnych ras świń utrzymywanych w Polsce (według danych Polskiego Związku Hodowców i Producentów Trzody Chlewnej „POLSUS”)

\begin{tabular}{|c|c|c|c|c|c|c|c|}
\hline \multirow[t]{2}{*}{ Rasa } & \multirow{2}{*}{$\begin{array}{c}\text { Rok, } \\
\text { w którym } \\
\text { wykonano } \\
\text { ocenę }\end{array}$} & \multicolumn{2}{|c|}{$\begin{array}{c}\text { Średnia grubość } \\
\text { słoniny standaryzo- } \\
\text { wana }(\mathrm{mm})\end{array}$} & \multicolumn{2}{|c|}{$\begin{array}{l}\text { Wysokość „oka” } \\
\text { polędwicy standary- } \\
\text { zowana (mm) }\end{array}$} & \multicolumn{2}{|c|}{$\begin{array}{c}\text { Zawartość mięsa } \\
\text { w tuszy standary- } \\
\text { zowana }(\%)\end{array}$} \\
\hline & & knurki & loszki & knurki & loszki & knurki & loszki \\
\hline \multirow{2}{*}{$\mathrm{Pbz}$} & 2008 & 9,3 & 10,3 & 55 & 54 & 59,3 & 57,8 \\
\hline & 2018 & 9,4 & 10,2 & 59 & 57 & 60,4 & 59,2 \\
\hline \multirow{2}{*}{ Wbp } & 2008 & 8,9 & 10,1 & 55 & 54 & 59,6 & 58,1 \\
\hline & 2018 & 8,9 & 10,1 & 61 & 58 & 60,8 & 59,6 \\
\hline \multirow{2}{*}{ Puławska } & 2008 & 12,4 & 13,6 & 54 & 54 & 55,7 & 54,8 \\
\hline & 2018 & 12,9 & 12,8 & 52 & 53 & 55,7 & 55,9 \\
\hline \multirow{2}{*}{ Duroc } & 2008 & 8,5 & 8,9 & 55 & 54 & 60,3 & 59,4 \\
\hline & 2018 & 8,9 & 9,5 & 64 & 60 & 61,9 & 60,0 \\
\hline \multirow{2}{*}{ Pietrain } & 2008 & 7,6 & 8,5 & 60 & 59 & 63,0 & 62,6 \\
\hline & 2018 & 7,7 & 8,0 & 65 & 64 & 63,6 & 63,4 \\
\hline \multirow{2}{*}{ Hampshire } & 2008 & 8,0 & 8,1 & 57 & 56 & 61,1 & 60,1 \\
\hline & 2018 & 8,8 & 9,5 & 65 & 67 & 61,5 & 62,0 \\
\hline
\end{tabular}

Celem pracy była analiza czynników, jakimi kierują się konsumenci przy wyborze wieprzowiny oraz wędlin podrobowych.

Aby uzyskać odpowiednie informacje, przeprowadzono badania ankietowe, w których wzięło udział 100 studentów Uniwersytetu Przyrodniczego w Lublinie w wieku od 18 do 26 lat, z czego 78\% stanowiły kobiety, a 22\% mężczyźni.

Wybór mięsa i jego przetworów przez konsumentów jest uwarunkowany wieloma aspektami o charakterze społecznym i ekonomicznym. Według informacji podanych przez respondentów najchętniej spożywane było mięso drobiowe $(58 \%)$, kolejno wieprzowina $(36 \%)$, oraz inne, tj. wołowina, cielęcina, baranina, dziczyzna (6\%) (ryc. 1).

Jednym z głównych czynników wyboru przez konsumentów mięsa drobiowego jest przede wszystkim jego stosunkowo niska cena, dostępność, łatwość przygotowania potrawy, różnorodność oferowanych gotowych dań do spożycia z tego gatunku mięsa oraz powszechne mniemanie o wysokiej jakości dietetycznej. Należy podkreślić, że studenci kierują się przede wszystkim możliwością szybkiego przygotowania posiłków, a każdy rodzaj wieprzowiny podczas obróbki musi być traktowany indywidualnie, co mogło mieć wpływ na wyniki ankiety [Rakowska 2013]. Niewątpliwie istotny wpływ na wybór pozostałych gatunków mięsa miał czynnik ekonomiczny, gdyż wołowina, cielęcina, baranina i dziczyzna należą do mięs drogich. Ponadto ważna jest również dostępność określonego mięsa w najczęściej preferowanych przez konsumentów miejscach jego zakupu, co w tym przypadku jest czynnikiem trudnym do spełnienia [Kwiecińska $\mathrm{i}$ in. 2018]. 


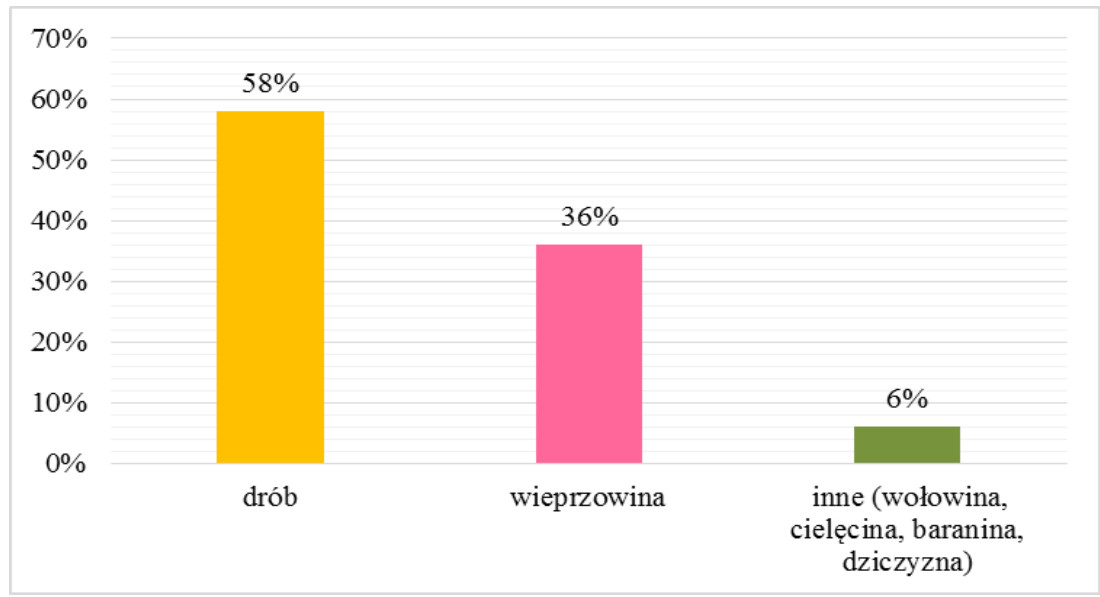

Ryc. 1. Procentowy rozkład odpowiedzi na pytanie „Jakie mięso najchętniej Pani/Pan spożywa?” Źródło: Opracowanie własne, podstawa - badania ankietowe

Zarówno spożycie, jak i nabywanie mięsa i podrobów wieprzowych przez konsumentów w głównej mierze zależy od czynników o charakterze społecznym i ekonomicznym, takich jak: kultura, religia, cena, jakość, pochodzenit i aktualna sytuacja epizootyczna dotycząca trzody chlewnej [Babicz-Zielińska 2015]. Należy jednak podkreślić, że polskie tradycje żywieniowe są oparte na wieprzowinie. Badania przeprowadzone przez Połom i Baryłko-Piekielną [2004] z zakresu preferencji żywieniowych dowiodły, że 89\% konsumentów ceni mięso wieprzowe jako surowiec kulinarny i przerobowy, a za główny argument uznano walory sensoryczne oraz wartość odżywczą.

Wieprzowina stanowi element zróżnicowanej diety, gdyż jest doskonałym źródłem składników odżywczych, które mają istotny wpływ na organizm człowieka. Najważniejszym składnikiem odżywczym mięsa i podrobów wieprzowych jest białko, którego udział w mięsie i podrobach waha się na poziomie $18-25 \%$ [Babicz i in. 2018, Brzóska 2001, Grześkowiak i in. 2009, Migdał i in. 2006]. Jest ono bardzo ważne dla organizmu człowieka, bowiem uczestniczy niemal we wszystkich procesach metabolicznych [Olszewski 2007]. Wartość biologiczna białka zawartego w mięsie świń wynosi $80 \%$ i jest najwyższa spośród białek innych gatunków mięsa zwierząt rzeźnych [Pikul i in. 2003].

Do ważnych składników wieprzowiny należą witaminy, których obecność $\mathrm{w}$ mięsie jest istotna $\mathrm{w}$ aspekcie jego wartości dietetycznej. Wieprzowina zawiera stosunkowo niską ilość sodu, tj. około $0,46 \mathrm{~g} / \mathrm{kg}$, co pozwala na umieszczenie jej w diecie osób chorych na nadciśnienie tętnicze. Ponadto jest cennym źródłem witaminy $\mathrm{E}$ oraz witamin $\mathrm{z}$ grupy $\mathrm{B}$. Najwięcej witaminy $\mathrm{B}_{6}$ występuje w karkówce, a wyższa mięsność tuszy zapewnia większy udział witaminy $\mathrm{B}_{1}$ [Blicharski i in. 2013]. Ponadto surowiec wieprzowy zawiera znaczną ilość żelaza, bardzo dobrze przyswajalnego przez organizm ludzki. Jak podają Blicharski i in. [2013], spośród elementów zasadniczych tuszy najwięcej żelaza znajduje się 
w karkówce, tj. 6,25 mg/100 g. Wartość ta jest wyższa średnio o 2,5 mg/100 g $\mathrm{w}$ porównaniu z zalecanym przez dietetyków szpinakiem. Ponadto żelazo z mięsa wchłania się kilkakrotnie lepiej niż z produktów roślinnych, co wynika $\mathrm{z}$ formy niehemowej żelaza zawartego $\mathrm{w}$ roślinach oraz obecności $\mathrm{w}$ nich substancji, które tworzą z żelazem nierozpuszczalne związki.

Wieprzowina zawiera również bioaktywne peptydy, takie jak tauryna i karnozyna. Działanie tauryny objawia się poprawą funkcjonowania mózgu, redukuje napięcie mięśniowe oraz wykazuje działanie przeciwmiażdżycowe [Szymański i in. 2008]. Karnozyna natomiast ma właściwości antyoksydacyjne, hamuje toksyczność jonów metali, opisywana jest także jako związek o charakterze przeciwstarzeniowym [Kiliśs-Pstrusińska 2012].

Jednym z budzących kontrowersje składników wieprzowiny jest cholesterol. Występuje on praktycznie w większości artykułów spożywczych pochodzenia zwierzęcego, jednakże to wieprzowina jest postrzegana jako jego główne źródło [Ciborowska $\mathrm{i}$ in. 2010]. Należy podkreślić, że związek ten jest niezbędny do prawidłowego funkcjonowania organizmu, między innymi bierze udział w syntezie witaminy $\mathrm{D}_{3}$ i hormonów, takich jak testosteron, estrogen, progesteron, kortyzol [Użarowska i in. 2018].

Dobrym źródłem składników odżywczych są również podroby wieprzowe. Są one jednak rzadziej wybierane przez konsumentów ze względu na walory sensoryczne czy tradycje żywieniowe. Faktem jest, że podroby jako artykuł spożywczy wywołują u części konsumentów skrajne odczucia, co może być związane z funkcjami, jakie pełniły jako narządy w organizmie zwierzęcia, a jednocześnie $\mathrm{z}$ walorami sensorycznymi, które są specyficzne a zarazem oryginalne.

Do podrobów najchętniej wykorzystywanych kulinarnie zalicza się nerki, wątrobę, serce, płuca i ozór. Elementy te cechują się stosunkowo wysokim udziałem pełnowartościowego białka, ponadto stanowią cenne źródło makroi mikroelementów [Babicz i in. 2018]. Przykładem jest wątroba szczególnie bogata w żelazo, której spożycie jest często zalecane przez dietetyków osobom z niedokrwistością [Szabłowska i in. 2018]. Z kolei mózg, oprócz oryginalnych walorów sensorycznych, może dostarczyć selenu i miedzi, tj. ważnych elementów w układzie odpornościowym.

W Polsce największą popularnością wyroby podrobowe cieszyły się w latach 70. i 80. XX w., stanowiąc tańszy, ale wartościowy zamiennik mięsa. Obecnie ich popularność rośnie z uwagi na walory smakowe oraz stosunkowo niską cenę [GUS 2018]. W wielu krajach europejskich podroby i wędliny podrobowe są uznawane za wyjątkowe produkty spożywcze i serwowane w najlepszych restauracjach [Nollet $i$ in. 2011].

Badanie przeprowadzone $\mathrm{z}$ udziałem ankietowanych na temat spożycia gotowych produktów podrobowych wykazało, że najczęściej konsumowany był pasztet (ryc. 2). Produkt ten wybierało podczas zakupów 54\% respondentów. Z kolei $22 \%$ osób preferowało pasztetową, a 16\% kaszankę. Najrzadziej spożywaną wędliną podrobową ( $8 \%$ ) był salceson. Taki rozkład wyników może być spowo- 
dowany cechami organoleptycznymi tych artykułów spożywczych, w tym głównie wyglądem, teksturą i smakiem.

Przedstawione wyżej zagadnienia odnośnie do wartości odżywczej mięsa i podrobów wieprzowych nie zawsze są brane pod uwagę przez konsumentów przy zakupie wieprzowiny. Stąd jedno z pytań ankiety brzmiało: „Na co zwraca Pani/Pan uwagę przy zakupie mięsa wieprzowego?”. Największa ilość ankietowanych (52\%) przy wyborze wieprzowiny kierowało się ceną (ryc. 3). Powodem może być to, że studenci, ze względu na zasobność swojego portfela, zwracają większą uwagę na cenę produktu niż na jakość. Cena surowca lub produktu zależy od dużej liczby czynników, takich jak: warunki ekonomiczne w kraju, koszt produkcji tuczników, rodzaj i jakość mięsa lub wyrobów. Obecnie w Polsce do najdroższych należy wieprzowina ekologiczna, wyprodukowana zgodnie z zasadami „bez GMO i antybiotyków”, pochodząca z rodzimych ras świń: puławskiej, złotnickiej białej, złotnickiej pstrej. Natomiast do najdroższych produktów mięsnych i podrobowych należą te wytworzone jako tradycyjne lub regionalne [Kropiwiec $\mathrm{i}$ in. 2016].

Jak wynika z przeprowadzonych badań, $30 \%$ ankietowanych przy zakupie mięsa i podrobów wieprzowych zwracało uwagę na ich barwę. Pozostała zaś część respondentów (18\%) przy wyborze kierowała się wcześniejszymi doświadczeniami kulinarnymi i smakowymi, nie zwracając uwagi na wartość odżywczą. Przedstawione wyniki mogą być konsekwencją braku wystarczającej wiedzy konsumentów na temat wartości odżywczej mięsa wieprzowego i zalet lub wad jego spożywania.

Bezpośrednio podczas zakupu mięsa i wędlin konsumenci kierują się głównie oceną wzrokową w zakresie określenia barwy jako wyznacznika świeżości. Nie bez znaczenia jest również stopień przetłuszczenia oraz konsystencja produktów. W tym aspekcie istotne znaczenie mają działania marketingowe, gdyż

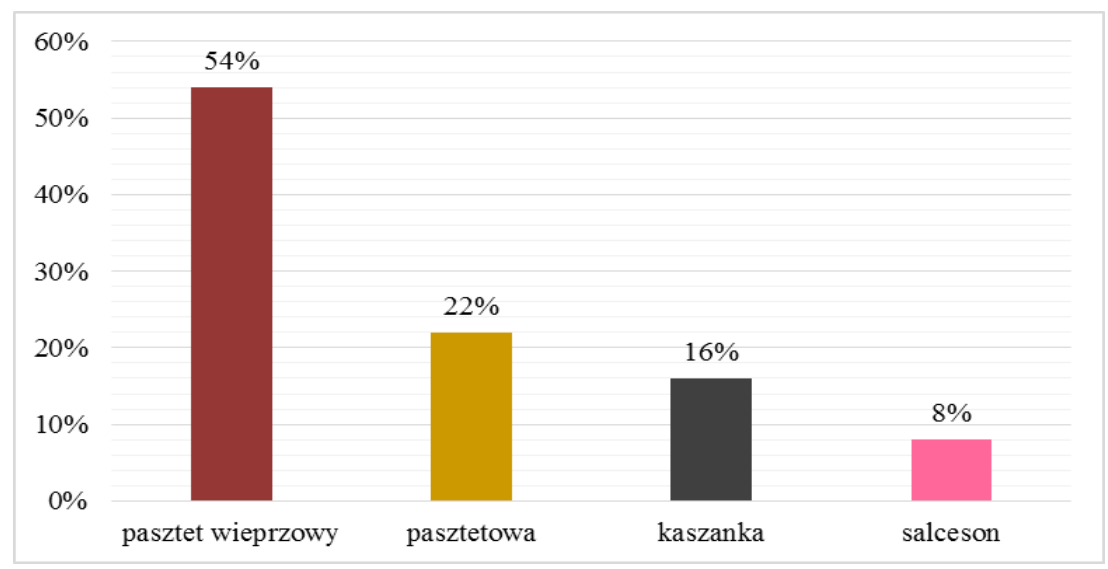

Ryc. 2. Procentowy rozkład odpowiedzi na pytanie ,Jakie wyroby podrobowe spożywa Pani/Pan najczęściej?"

Źródło: Opracowanie własne, podstawa - badania ankietowe 


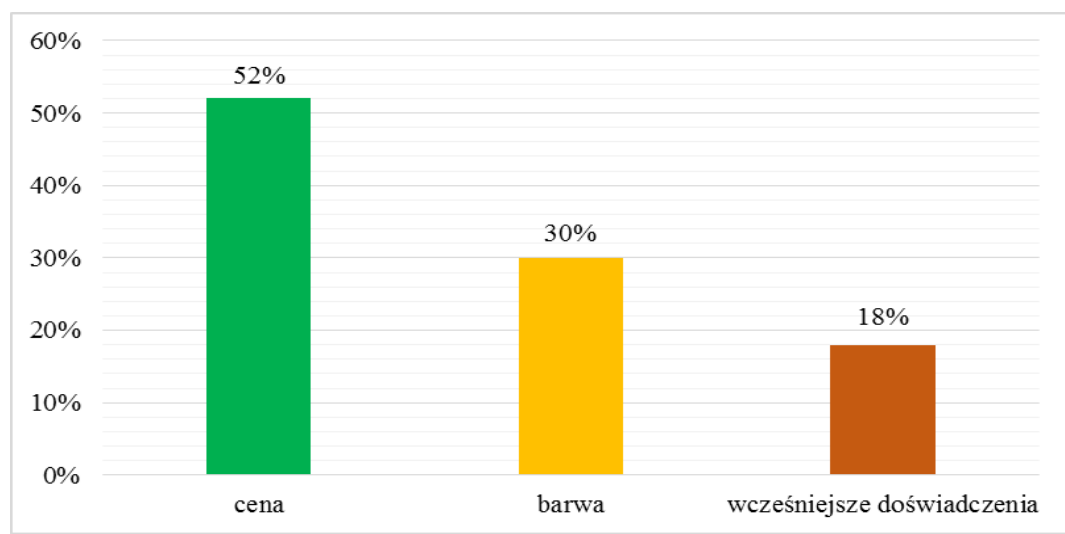

Ryc. 3. Procentowy rozkład odpowiedzi na pytanie „Na co zwraca Pani/Pan uwagę przy zakupie mięsa i podrobów wieprzowych?"

Źródło: Opracowanie własne, podstawa - badania ankietowe

ekspozycja, oświetlenie czy wygląd opakowania, również wpływa na ostateczny wybór [Malinowska in. 2014]. Część konsumentów przy wyborze produktu kieruje się oznaczeniami jakościowymi, które można znaleźć na opakowaniach, np.: PQS (Pork Quality System), QAFP (Quality Assurance for Food Products). Jednakże dla wielu klientów oznaczenia te nie są znane.

Jak wynika $\mathrm{z}$ badań własnych, najważniejszym kryterium wyboru mięsa była jego świeżość, na którą wskazało 58\% ankietowanych (ryc. 4). Natomiast 22\% respondentów kierowało się datą przydatności do spożycia danego produktu. Ważnym bodźcem dla ankietowanych $(20 \%)$ była również marka. Coraz częściej można się spotkać z tendencją do nabywania przez konsumentów wędlin wysokogatunkowych, np. tradycyjnych, co jest spowodowane sentymentem do produktów domowych o wysokiej jakości.

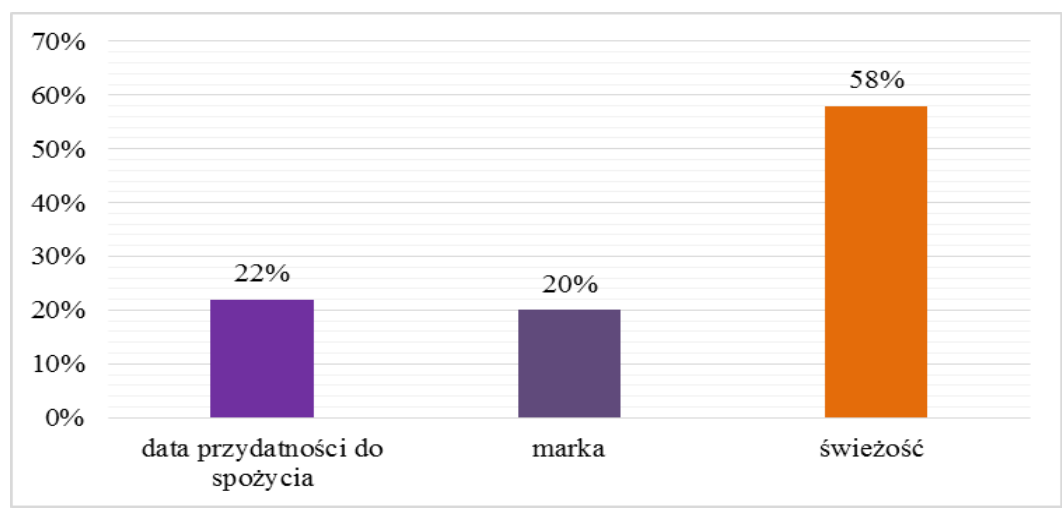

Ryc. 4. Procentowy rozkład odpowiedzi na pytanie ,Jakie jest dla Pani/Pana kryterium jakościowe podczas zakupu mięsa?"

Źródło: Opracowanie własne, podstawa - badania ankietowe 
Jakość to bardzo ważne kryterium, którym kierują się kupujący przy wyborze mięsa. Każdy nabywca inaczej charakteryzuje jakość surowca. Obecnie w masowej produkcji wieprzowiny uwzględnia się jedynie mięsność surowca, gdyż przeciętny konsument poszukuje mięsa wybitnie chudego, a tym samym o wysokiej zawartości białka. Jednocześnie należy podkreślić, że istotnym wyróżnikiem jakości jest zawartość tłuszczu, ponieważ wpływa na kruchość, soczystość oraz na odczucia smaku i zapachu [Orzechowska $i$ in. 2012]. Dlatego coraz częściej produkowany jest surowiec rzeźny i wędliny wysokogatunkowe, zwłaszcza z wykorzystaniem rodzimych ras świń [Babicz i in. 2010, Cebulska 2015].

Jak wykazano, ważnym czynnikiem wyboru było również miejsce zakupu mięsa i wędlin podrobowych (ryc. 5). W badaniu ankietowym $52 \%$ respondentów uważało, iż najlepsze jakościowo mięso wieprzowe i wędliny podrobowe są dostępne w sklepie mięsnym. Z kolei 38\% respondentów było zdania, że należy dokonać takiego zakupu bezpośrednio od producenta. Jedynie $10 \%$ ankietowanych twierdziło, że mięso wysokiej jakości znajduje się w hipermarketach i sklepach osiedlowych.

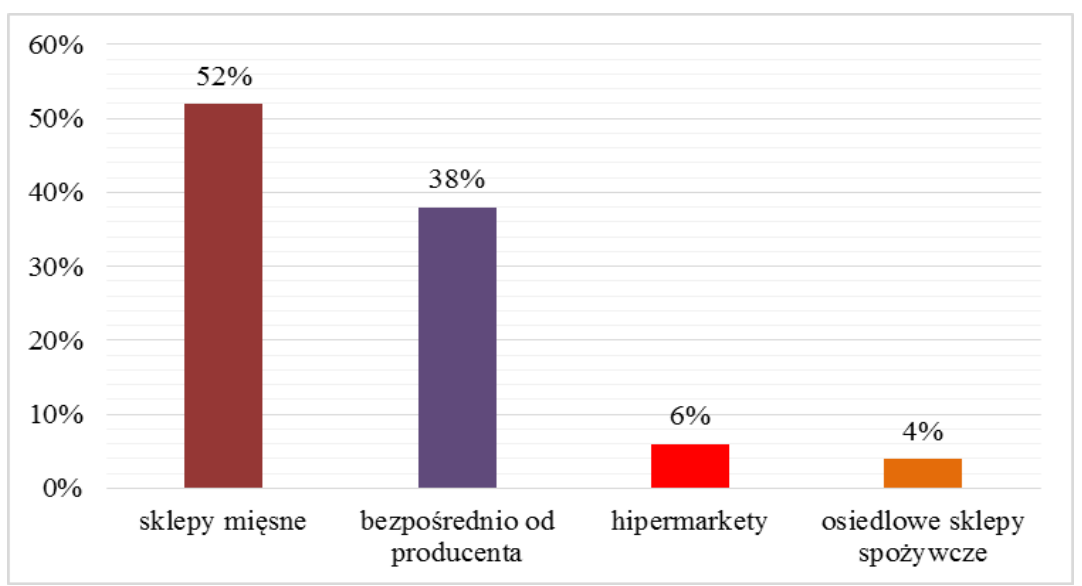

Ryc. 5. Procentowy rozkład odpowiedzi na pytanie „Gdzie Pani/Pana zdaniem można kupić mięso i podroby wieprzowe najwyższej jakości?"

Źródło: Opracowanie własne, podstawa - badania ankietowe

Elementem, który również wpływa na akceptowalność społeczną wieprzowiny i podrobów, jest religia. W Polsce według spisu powszechnego z $2011 \mathrm{r}$. [GUS 2012] ponad 5000 osób to wyznawcy islamu. Religia tej populacji nie pozwala na spożycie mięsa wieprzowego, podrobów ani żadnych produktów $\mathrm{z}$ nich wytworzonych. Również $\mathrm{w}$ religii chrześcijańskiej istnieją ograniczenia, np. zakaz spożywania mięsa w piątki oraz w czasie postów określonych terminarzem świąt. Jak stwierdzono, spośród ankietowanych $48 \%$ osób podczas wyboru mięsa wieprzowego kierowało się aspektem religii. Natomiast duża część, bo 30\% spośród badanych, brała pod uwagę obecną sytuacją społeczno-ekonomiczną. Pozostali ankietowani (22\%) podczas zakupu mięsa wieprzowego i podrobów uwzględ- 
niali obecną sytuację epidemiologiczną związaną z afrykańskim pomorem świń (African Swine Fever). ASF jest to zakaźna choroba wirusowa dotycząca świń domowych i dzików. Wirus ten jest śmiertelny dla świń, jednakże zagraża ludziom, to istnieje zakaz spożywania mięsa pozyskanego z tuczników, które miały kontakt z zarażonym zwierzęciem. Głównym tego powodem jest możliwość rozprzestrzeniania się wirusa ASFV (African Swine Fever Virus) poprzez resztki jedzenia i odpadki mięsne [Pejsak i in. 2017]. W przypadku występowania ASF i spożycia wieprzowiny istnieje ujemna zależność, przejawiająca się obawą przed spożyciem tego gatunku mięsa, podrobów i ich przetworów.

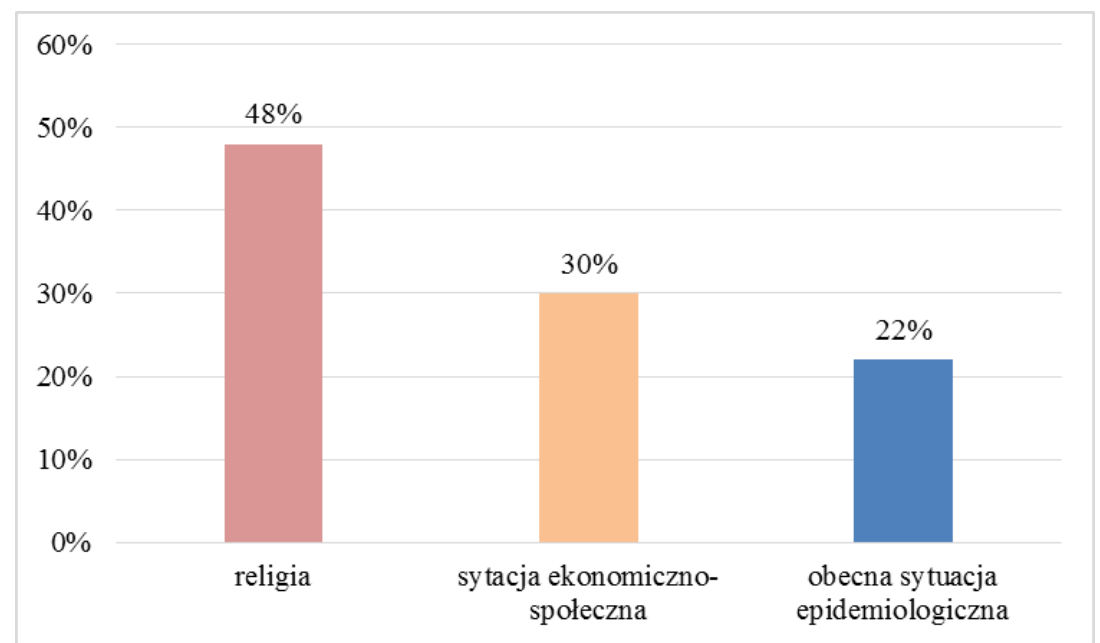

Ryc. 6. Procentowy rozkład odpowiedzi na pytanie „Czym kieruje się Pani/Pan podczas wyboru mięsa wieprzowego?"

Źródło: Opracowanie własne, podstawa - badania ankietowe

Podsumowując, należy stwierdzić, że mięso wieprzowe i wędliny podrobowe są obecnie znaczącym składnikiem diety konsumentów w Polsce. Czynniki wyboru tych artykułów spożywczych przez konsumentów są dość zróżnicowane. Jednym z ważniejszych jest cena (52\% ankietowanych). Inne to świeżość oferowanego produktu (58\% ankietowanych) i miejsce jego zakupu (sklepy mięsne $52 \%$ ankietowanych). Ważnymi elementami okazały się także aspekt religii (48\% ankietowanych) i sytuacja ekonomiczno-społeczna (30\% ankietowanych).

\section{Bibliografia}

Babicz M., Kamyk P., Rejduch B., Kozubska-Sobocińska A., Stasiak A., Lechowski J., 2010. Wykorzystanie świń rasy puławskiej do produkcji wieprzowiny o specyficznej jakości. Med. Wet. 66(8), 555-558. 
Babicz M., Kropiwiec K., Szyndler-Nędza M., Skrzypczak E., 2018. The physicochemical properties of offal from puławska gilts in relation to carcass meatiness. Ann. Anim. Sci. 18(1), 239-249, https://10.1515/aoas-2017-0018.

Babicz-Zielińska E., Jeżewska-Zychowicz M., 2015. Wpływ czynników środowiskowych na wybór i spożycie żywności. Hand. Wew. 2(355), 5-18.

Blicharski T., Książek P., Pospiech E., Migdał W., Jóźwik A., Poławska E., Lisiak D., 2013. Aktualna wartość dietetyczna wieprzowiny, jej znaczenie w diecie i wpływ na zdrowie konsumentów. PZHiPFCh „POLSUS”, Warszawa.

Brzóska F., 2001. Parametry oceny jakości mięsa wieprzowego. Biuletyn Inf. IZ PiB. 39(4), 63-71.

Cebulska A., 2015. Jakość mięsa świń polskich ras rodzimych i mieszańców wysokoprodukcyjnych oraz jego przydatność do pozyskiwania żywności o właściwościach funkcjonalnych. Rozprawa dokt. Wyd. UTP w Bydgoszczy, Bydgoszcz.

Ciborowska H., Rudnicka A., 2010. Dietetyka żywienia zdrowego i chorego człowieka, PZWL, Warszawa.

Grześkowiak E., Borys A., Borzuta K., Buczyński J.T., Lisiak D., 2009. Slaughter value, meat quality and backfat fatty acid profile in Zlotnicka White and Zlotnicka Spotted fatteners. Anim. Sci. Pap. Rep. 27(2), 115-125.

GUS - Główny Urząd Statystyczny, 2018. Rocznik Statystyczny Rolnictwa, Warszawa.

GUS - Główny Urząd Statystyczny, 2012. Narodowy Spis Powszechny Ludności i Mieszkań, Warszawa.

Kiliś-Pstrusińska K., 2012. Carnosine, carnosinase and kidney diseases Post. Hig. Med. Dośw. 66, 215-221, https://10.5604/17322693.991600.

KOWR - Krajowy Ośrodek Wsparcia Rolnictwa. 2019. Sytuacja podażowo-popytowa i cenowa na podstawowych rynkach rolnych, Biuro Analiz i Strategii, Warszawa.

Kropiwiec K., Bany M., Babicz M., 2016. Wieprzowe produkty regionalne szansą rozwoju gospodarstw rodzinnych na Lubelszczyźnie. W: M. Szala. K. Kropiwiec (red.), Przegląd wybranych zagadnień z zakresu przemysłu spożywczego. Wyd. Nauk. TYGIEL, Lublin, 235-244.

Kwiecinska K., Kosicka-Gębska M., Gębski J., 2018. Dostępność dziczyzny na polskim rynku w kontekście potrzeb konsumentów. Zesz. Nauk. SGGW. Ekonomika i Organizacja Gospodarki Żywnościowej 121, 83-91. https://10.22630/EIOGZ.2018.121.6.

Malinowska E., Wiśniewska M.Z., Szymańska-Brałkowska M., 2014. Ocena sensoryczna jakości produktów żywnościowych, Zakł. Zarządzania Jakością i Środowiskiem, Wydz. Zarządzania Uniw. Gdański, Sopot.

Migdał W., Orzechowska B., Różycki M., Tyra M., Wojtysiak D., Duda I. 2006. Chemical composition and texture parameters of loin from polish landrace, polish large white and pietrain fatteners. Ann. Anim. Sci. Supl. 2(2), 375-378.

Nollet L.M.L., Toldrá F., 2011. Introduction of offal meat: Definitions, regions, cultures, generalities. W: L.M.L. Nollet, F. Toldrá (red.), Handbook of Analysis of Edible Animal By-Products. CRC Press, Floryda, 3-11.

Olszewski A., 2007. Technologia przetwórstwa mięsa, WNT, Warszawa.

Orzechowska B., Tyra M., Mucha A., Żak G., 2012. Jakość tusz świń ras wbp i pbz ze szczególnym uwzględnieniem zawartości tłuszczu śródmięśniowego [IMF] w zależności od poziomu mięsności. Rocz. Nauk. Zoot. 39(1), 77-85.

Pejsak Z., Woźniakowski G., Śmietanka K., Ziętek-Barszcz A., Bocian Ł., Frant M., Niemczuk K., 2017. Przewidywany rozwój sytuacji epizootycznej w zakresie afrykańskiego pomoru świń w Polsce. Życie Weter. 92(4), 255-260.

Pikul J., Pospiech E., Oziemkowski P., 2003. Białka pochodzenia zwierzęcego, ich charakterystyka i znaczenie w żywności. W: J. Gawęcki (red.), Białka w żywności i żywieniu. Wyd. AR w Poznaniu, Poznań, 22-41.

PN-65/A-82000, 1965. Mięso i podroby zwierząt rzeźnych - wspólne wymagania i badania. PKN, Warszawa.

PN-86/A-82004, 1986. Podroby zwierząt rzeźnych. PKN, Warszawa. 
Połom A., Baryłko-Pikielna N., 2004. Analiza czynników decydujących o preferencjach polskich konsumentów mięsa wieprzowego. Żywn. Nauk. Technol. Jakość. 3 (40), 7-23.

Rakowska R., 2013. Wpływ obróbki termicznej na zmiany wartości odżywczej mięsa. Postępy Tech. Przetw. Spoż. 2, 113-117.

Szabłowska A., Pyć M., 2018. Zachowania zdrowotne osób z niedokrwistością spowodowaną niedoborem żelaza. Aspekty Zdrowia i Choroby 3(1), 35-53.

Szymański K., Winiarska K., 2008. Tauryna i jej potencjalne wykorzystanie w terapii. Post. Hig. Med. Dośw. 62, 75-86.

Tyra M., 2013. Zależności pomiędzy cechami użytkowości rzeźnej a zawartością tłuszczu śródmięśniowego [IMF] w mięśniu najdłuższym grzbietu krajowej populacji świń. Rocz. Nauk. Zoot. 40(1), 3-14.

Użarowska M., Surman M., Janik M., 2018. Dwie twarze cholesterolu: znaczenie fizjologiczne i udział w patogenezie wybranych schorzeń. Kosmos. 67(2), 375-390. 


\title{
Joanna Jędrusyna ${ }^{1,3}$, Aleksandra Krochmal ${ }^{1}$, Anna Teter ${ }^{2}$, Monika Kędzierska-Matysek ${ }^{2}$
}

\section{Jakość mlecznych produktów fermentowanych wyróżnionych znakiem „Jakość Tradycja”}

\author{
Quality of fermented milk products with the "Quality Tradition" label
}

Z uwagi na korzystny wpływ na zdrowie i walory odżywcze mleczne napoje fermentowane odgrywają istotną rolę w diecie człowieka. Produkty te zaliczane są do żywności funkcjonalnej. Na rynku produkty te są powszechnie dostępne. W sklepach można spotkać napoje fermentowane odmiennych marek oraz o różnej jakości. W celu ułatwienia decyzji konsumentowi, który produkt wybrać spośród wielu, powstały metody wyróżnienia produktów spożywczych, w tym produktów mlecznych za pomocą znaków jakości [Kudełka 2005, Danków i in. 2013, Haska i Martyniuk 2019].

Znaki jakości mają na celu ułatwić konsumentowi rozpoznanie oraz przypisanie cech i właściwości produktom spożywczym. Problemem jest jednak duża różnorodność systemów certyfikacji obecnych na rynku, która może prowadzić do dezorientacji konsumentów. Rozpoznawalność systemów jakości żywności w Polsce jest stosunkowo niewielka. Nawet jeśli konsumenci rozpoznają znak jakości, mają słabą wiedzę na temat jego znaczenia. Być może wynika to z braku lub niewielkiej dostępności informacji dotyczącej systemów. Jeśli konsumenci zidentyfikują znak jakości, ma on możliwość stać się kluczowym kryterium przy wyborze produktu. Jeżeli nie są świadomi znaczenia certyfikatu, to wtedy zwracają uwagę głównie na ceną, pochodzenie produktu lub jego wygląd [Vecchio i Annunziata 2011, Soregaroli i in. 2003].

Poniżej przedstawiono charakterystykę mlecznych napojów fermentowanych, wyróżniki ich jakości oraz zasady wyróżniania produktów znakiem „Jakość Tradycja".

\footnotetext{
${ }^{1}$ SKN Nauk o Zwierzętach i Biogospodarki, Sekcja Towaroznawstwa i Bezpieczeństwa Żywności, Wydział Nauk o Zwierzętach i Biogospodarki, Uniwersytet Przyrodniczy w Lublinie

${ }^{2}$ Instytut Oceny Jakości i Przetwórstwa Produktów Zwierzęcych, Wydział Nauk o Zwierzętach i Biogospodarki, Uniwersytet Przyrodniczy w Lublinie

${ }^{3}$ e-mail: asia.1709@o2.pl
} 


\section{Charakterystyka mlecznych napojów fermentowanych}

Kefir zaliczany jest do najstarszych napojów fermentowanych. Historia kefiru wywodzi się z Kaukazu, gdzie produkowano go ponad 3000 lat temu z mleka krowiego lub koziego w dębowych beczkach lub w skórzanych workach. W Europie kefir jest znany od połowy XIX w. [Nadolna i Kunachowicz 2005].

Według definicji zawartej w PN-A-86061:2002, „kefir jest to mleko fermentowane zawierające użytą do fermentacji charakterystyczną mikroflorę ziaren kefirowych z gatunku Lactobacillus kefir, rodzaju Lactococcus, rodzaju Leuconostoc i Acetobacter oraz drożdże fermentujące laktozę - Kluyveromyces marxianus i niefermentujące laktozy Saccharomyces unisporus, Saccharomyces exiguus, Saccharomyces cerevisiae, żyjące w ścisłej symbiozie".

Nazwa jogurt wywodzi się z języka tureckiego - „ya-urt”, co w thumaczeniu oznacza „kwaśne mleko”. Historia jogurtu sięga ok. 3000 lat wstecz. Spożywano go w Egipcie i Babilonie, później również na terenie Bułgarii i Turcji. Za jego ojczyznę uważa się Indie. Jogurt produkuje się z mleka pasteryzowanego za pomocą fermentacji mlekowej. Podczas fermentacji dodawane są bakterie Lactobacillus delbrueckii ssp. bulgaricus i Streptococcus thermophilus. Do jogurtów nowej generacji dodawane są szczepy Lactobacillus acidophilus i Bifidobacterium [Koluch i Marchewka 2009, Mojka 2013].

Powołując się na Polską Normę [PN-A-86061:2002] Mleko i przetwory mleczne - maślanka to „mleko fermentowane otrzymane w wyniku fermentacji $\mathrm{z}$ użyciem charakterystycznych maślarskich kultur, tj. Lactococcuslactis subspecies cremoris, Lactococcuslactis subspecies lactis oraz Leuconostoc mesenteroides subspecies cremoris".

Zsiadłe mleko nazywane jest także mlekiem ukwaszonym. Otrzymuje się je ze świeżego, niepasteryzowanego i niesterylizowanego mleka odstawionego $\mathrm{w}$ temperaturze otoczenia do skwaśnienia. $\mathrm{W}$ mleku zachodzi proces fermentacji mlekowej [Krzyżewski i in. 1997]. Proces ten sprawia, że mleko rozwarstwia się na dwie części. Pierwsza część jest gęsta, w postaci skrzepu kwasowego, drugą natomiast tworzy płynna serwatka. W przypadku produkcji zsiadłego mleka na skalę przemysłową, mleko zaszczepiane jest czystymi kulturami mlecznych paciorkowców, tj. Lactobacilluslactis ssp. lactis [Litwińczuk 2011, Król i Brodziak 2016].

\section{Wartość odżywcza oraz właściwości prozdrowotne wybranych mlecznych napojów fermentowanych}

Mleczne napoje fermentowane naturalnie wpływają na zdrowie człowieka poprzez swoje prozdrowotne właściwości, wartość odżywczą i obecność żywych kultur bakterii, które działają stymulująco na procesy trawienne. Produkty te zawierają pełnowartościowe białko o zbilansowanym składzie aminokwasowym. Ze względu na zalety płynące ze spożycia mleczne produkty fermentowany po- 
winny stanowić uzupełnienie naszej codziennej diety [Gawęcki i Mossor-Pietraszewska 2006, Krasnowska i Slejda 2008, Żelazowski 2015].

Dla zdrowia człowieka kefir ma wiele dobroczynnych właściwości, które wynikają z obecności naturalnych probiotyków. Jest źródłem mikroorganizmów, które wspierają rozwój właściwej mikroflory organizmu i uniemożliwiają rozwój bakterii chorobotwórczych. Poprzez swoją mikroflorę stymuluje układ odpornościowy oraz ma właściwości antynowotworowe [Turek i in. 2019]. Kefir korzystnie wpływa na układ pokarmowy, gdyż poprawia perystaltykę jelit. Jest dobrym źródłem witamin z grupy B: B1, B12, witaminy K i biotyny. Dostarcza wapnia i magnezu, czyli pierwiastków kluczowych dla mocnych i zdrowych kości. Obecny w kefirze tryptofan wpływa pozytywnie na układ nerwowy oraz działa wyciszająco [Baranowska 2009, Mojka 2013].

Jogurt należy do grupy najbardziej popularnych oraz najczęściej spożywanych mlecznych napojów z powodu tego, że zawiera wiele cennych składników mineralnych jak: potas, fosfor, wapń oraz magnez. Produkt ten, będąc bogatym źródłem wapnia, wzmacnia zęby oraz kości, dlatego zalecane jest jego spożycie w profilaktyce i leczeniu próchnicy oraz osteoporozy. O wysokiej wartości odżywczej jogurtu decyduje obecność znacznych ilości witaminy $\mathrm{B}_{2}$, witaminy PP oraz witaminy $\mathrm{B}_{12}$ produkowanej przez bakterie stosowne do fermentacji mleka. W przypadku kuracji antybiotykowej wspomaga on regenerację mikroflory jelitowej, ze względu na obecność bakterii fermentacji mlekowej [Czerwińska 2012, Mojka 2013].

Maślanka w 91\% składa się z wody, cukier mlekowy (laktoza) stanowi 4\%, a $1,5 \%$ to thuszcz. Zawiera ona szereg witamin z grupy B (B1, B2, B12) oraz składniki mineralne takie jak: wapń, sód, potas, fosfor, magnez i selen. Witaminy z grupy B mają pozytywne znaczenie w prawidłowym funkcjonowaniu mięśni, wpływają korzystnie na stan układu sercowo-naczyniowego i regulują pracę układu nerwowego. Maślanka to źródło lecytyny, która korzystnie wpływa na procesy przemiany materii oraz detoksykację i regenerację wątroby. Niezwykle cennym składnikiem maślanki jest kwas mlekowy, który pobudza wydzielanie soku żołądkowego, co przyczynia się do łatwiejszego trawienia. Obecność bakterii fermentacji mlekowej zasila florę jelitową, tym samym poprawiając pracę jelit. Ponadto jest produktem lekkostrawnym, a regulując i przyspieszając przemianę materii, wspomaga odchudzanie [Nowak i in. 2007].

Spożywanie zsiadłego mleka również wnosi wiele korzyści dla naszego zdrowia. Obecne w nim bakterie wzbogacają florę bakteryjną jelit, co przyczynia się do poprawienia odporności. Regularne picie zsiadłego mleka usprawnia perystaltykę jelit, a także wpływa na lepsze trawienie. Zsiadłe mleko mogą pić osoby z nietolerancją laktozy. Jego spożycie zapobiega chorobie wrzodowej, chroni przed zapaleniem żołądka oraz przyczynia się do obniżenia poziomu cholesterolu. Napój ten jest źródłem witamin, tj. B12, B2, A, K2 oraz łatwo przyswajalnego wapnia, fosforu i potasu [Kukułowicz 2017]. 


\section{Probiotyczne bakterie fermentacji mlekowej - właściwości i wykorzystanie}

Według definicji FAO/WHO z 2002 r., probiotyki to żywe mikroorganizmy, które podawane w odpowiednich ilościach wywierają korzystne skutki zdrowotne.

Probiotyki są to pojedyncze lub mieszane kultury żywych bakterii, które wprowadzone do organizmu w odpowiedniej ilości, dzięki swoistym zdolnościom, przynoszą korzyści zdrowotnie (ryc. 1). Jednak, aby szczep mógł być zatwierdzony w grupie probiotyków, musi wykazać szereg udokumentowanych klinicznie korzyści zdrowotnych, a jego działanie probiotyczne może odnosić się wyłącznie do jednego szczepu testowego, nie do gatunku, rodzaju czy do ogółu bakterii mlekowych. Probiotyki poprzez konkurowanie z patogenami obecnymi w jelitach człowieka o składniki odżywcze, mają na celu aktywnie wpływać na zdrowie człowieka. Zapobiegają chorobom, tj. atopowe zapalenie skóry, marskość wątroby oraz reumatoidalne zapalenie stawów [Żelazowski 2015].

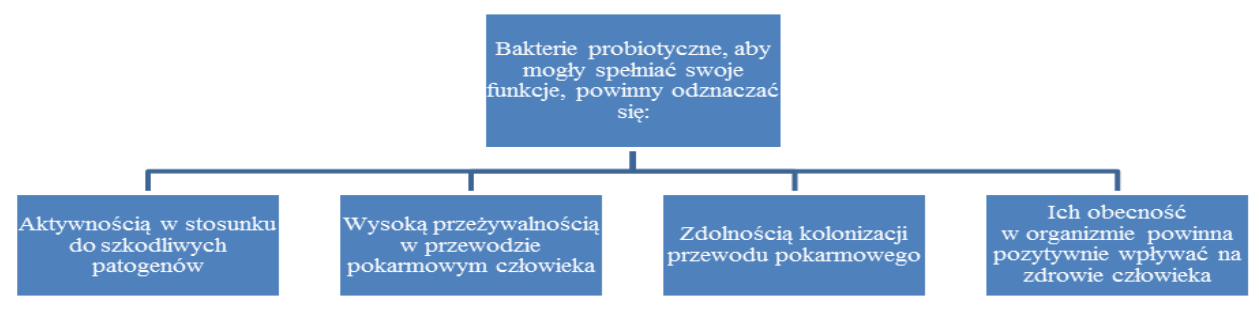

Ryc. 1. Właściwości bakterii probiotycznych.

Źródło: Opracowanie własne na podstawie Nowak i in. [2007], Żelazowski [ 2015]

Codex Alimentarius wskazuje, że aby dany mleczny napój fermentowany mógł zostać uznany jako produkt probiotyczny, liczebność bakterii probiotycznych w 1 g produktu nie może być mniejsza niż $10^{6}$ jtk. Poniżej tej wartości mikroorganizmy nie spełniają swojej funkcji.

Obecnie probiotyczne napoje mleczne i jogurty produkowane są kilkoma sposobami:

- bez fermentacji, poprzez dodanie bakterii do świeżego mleka,

- mleko ulega fermentacji przy obecności bakterii probiotycznych,

- jogurt, w którym dodawane są probiotyczne szczepy Lactobacillus oprócz dodatku bakterii startowej [Ziółkowski 2012].

\section{Charakterystyka systemu „Jakość Tradycja”}

Istnieje wiele dobrowolnych, nieobligatoryjnych systemów, które ułatwiają konsumentowi rozpoznanie produktów spożywczych. Każdy kraj ma prawo do tworzenia własnych, krajowych systemów jakościowych. Obecnie w Polsce 
wyróżniamy pięć systemów jakości, które są uznane przez Ministra Rolnictwa i Rozwoju Wsi. Jednym z takich systemów jest system „Jakość Tradycja”. Produkty oznaczone tym znakiem podlegają kontroli i certyfikacji przez jednostki do tego upoważnione. Postępowanie takie zapewnia gwarancję uzyskania produktu wysokiej jakości, a oznaczenie umożliwiają jego identyfikację [Gąsiorowski 2005, Kieljan 2011].

Znak „Jakość Tradycja” to pierwszy polski znak w krajowych systemach jakości żywności. Został utworzony dla wyróżnienia i promocji produktów żywnościowych o wysokiej jakości z uwzględnieniem produktów tradycyjnych. Opracowany został przez Polską Izbę Produktu Regionalnego i Lokalnego, natomiast 12 czerwca 2007 r. uznany decyzją Ministra Rolnictwa i Rozwoju Wsi. Niespełna dwa lata później, bo 22 czerwca 2009 r. został uznany przez Komisję Europejską [Kokotkiewicz i in. 2018, Modrzyńska 2018].

\section{Wymagania dotyczące systemu}

Do systemu przyjmowane są produkty, które charakteryzują się tradycyjnym składem, tradycyjnym sposobem wytworzenia oraz szczególną jakością, która wynika z ich tradycyjnego charakteru. Za tradycyjne uważa się produkty, które posiadają co najmniej 50-letni rodowód (dwa pokolenia). Za tradycyjne rasy i odmiany uważa się te, które użytkowano przed 1956 r. Surowce wykorzystane przy produkcji muszą pochodzić z gospodarstw ekologicznych lub z gospodarstw o systemie produkcji stosujących Dobrą Praktyką Rolniczą i Dobrą Praktykę Hodowlaną z wyłączeniem GMO [http://www.produktytradycyjne.pl/certyfikat-jakosc-tradycja].

Producent zobowiązany jest do deklarowania zachowania wyższych standardów produkcyjnych lub wyjątkowych cech produktów. W systemie przed dopuszczeniem do uczestnictwa produkt podlega szczegółowej weryfikacji zgodnie z Regulaminem Znaku, który został przyjęty przez Urząd Patentowy Rzeczypospolitej Polskiej, a wcześniej zatwierdzony przez Radę, Zarząd Izby oraz Związek Województw Rzeczypospolitej Polskiej. Znak „Jakość Tradycja” jest znakiem zarejestrowanym w Urzędzie Patentowym. Chroniony jest zgodnie z prawem własności przemysłowej jako wspólny znak gwarancyjny. Producenci są zobowiązani do posiadania certyfikatu zgodności, który potwierdza wytwarzanie produktu zgodnie ze specyfikacją. Są zobowiązani do określenia częstotliwości i zakresu kontroli. W celu zapewnienia pełnej identyfikowalności produktu (traceability) mają za zadanie prowadzenie dokumentacji. Podczas przynależności do systemu producenci mają obowiązek poddawania się okresowej kontroli jakości. Do systemu organizowanego przez Polską Izbę Produktu Regionalnego i Lokalnego we współpracy ze Związkiem Województw Rzeczypospolitej Polskiej mogą przystąpić producenci rolni, wszyscy rolnicy, przetwórcy w kraju i za granicą oraz członkowie Izby i nienależący do niej. 
Tabela 1. Produkty mleczne wyróżnione znakiem „Jakość Tradycja” w województwie lubelskim [na dzień 22.03.2020]

\begin{tabular}{|l|l|}
\hline \multicolumn{1}{|c|}{ Nazwa produktu } & \multicolumn{1}{c|}{ Producent } \\
\hline $\begin{array}{l}\text { Masło z Bychawy } \\
\text { Twaróg chudy z Bychawy } \\
\text { Twaróg półtłusty z Bychawy } \\
\text { Twaróg tłusty z Bychawy }\end{array}$ & $\begin{array}{l}\text { Okręgowa Spółdzielnia Mleczarska } \\
\text { w Bychawie }\end{array}$ \\
\hline $\begin{array}{l}\text { Twarożek babuni półtłusty z Michowa } \\
\text { Twarożek babuni tłusty z Michowa } \\
\text { Masło ekstra z Michowa }\end{array}$ & Spółdzielnia Mleczarska „Michowianka” \\
\hline Ser rycki Edam & Spółdzielnia Mleczarska Ryki \\
\hline Zsiadłe mleko z Krasnegostawu & $\begin{array}{l}\text { Okręgowa Spółdzielnia Mleczarska } \\
\text { w Krasnymstawie }\end{array}$ \\
\hline $\begin{array}{l}\text { Kefir jak dawniej } \\
\text { Zsiadłe mleko piaseckie jak dawniej } \\
\text { Twaróg piasecki śmietankowy }\end{array}$ & $\begin{array}{l}\text { Okręgowa Spółdzielnia Mleczarska } \\
\text { w Piaskach }\end{array}$ \\
\hline $\begin{array}{l}\text { Masło śmietankowe nadbużańskie } \\
\text { Śmietana } 18 \% \\
\text { Twaróg półtłusty }\end{array}$ & $\begin{array}{l}\text { Spółdzielnia Mleczarska „Bieluch” } \\
\text { w Chełmie }\end{array}$ \\
\hline
\end{tabular}

Obecnie w systemie uczestniczy 144 producentów z 15 regionów. Do 25 lutego 2020 r. zarejestrowano 321 produktów posiadających certyfikat „Jakość Tradycja”. Do województw o największej liczbie certyfikowanych produktów zaliczamy: łódzkie (71 produktów od 28 producentów), mazowieckie (43 produkty od 18 producentów), wielkopolskie (40 produktów od 19 producentów), małopolskie (24 produkty od 12 producentów), lubelskie ( 23 produkty od 10 producentów), świętokrzyskie (23 produkty od 12 producentów) oraz podkarpackie (22 produkty od 8 producentów). Certyfikat „Jakość Tradycja” obejmuje różne kategorie produktów spożywczych, m.in. mleczne; przetwory cukiernicze i piekarnicze; wędliny; przetwory warzywne i owocowe; kasze, mąki, makarony; gotowe dania i potrawy; napoje spirytusowe; produkty rybołówstwa, w tym ryby; olej i thuszcze; miody. W tabeli 1 wymienione zostały produkty mleczne wyróżnione znakiem „Jakość Tradycja” w województwie lubelskim [http://www.produkty-regionalne.pl/jakosc].

\section{Jakość zsiadłego mleka z produkcji masowej oraz wyróżnionego znakiem „Jakość Tradycja”}

Oceniono właściwości fizykochemiczne zsiadłego mleka od 4 producentów. Oceniono po 2 produkty z 3 partii produkcyjnych (łącznie 24 produkty). Były to produkty wyróżnione znakiem jakości oraz z produkcji masowej. Charakterystykę wykorzystanych do badań produktów przedstawiono w tabeli 2.

Oznaczono kwasowość czynną (pH, za pomocą pehametru Elmetron,CP-401), miareczkową (wyrażoną w stopniach Soxhleta-Henkla) wg PN-A-86061:2002; Mleko i przetwory mleczne - Mleko fermentowane. W celu przeliczenia kwa- 
sowości na procent kwasu mlekowego otrzymany wynik w ${ }^{\circ} \mathrm{SH}$ przemnożono przez współczynnik 0,0225. Aktywność wody (Aw) oznaczono aparatem HygroLab C1 Rotronic z sondą HCZ-AW. Instrumentalny pomiar barwy wykonano chromametrem MinoltaCR-310 (MinoltaCamera Co. Japonia). Wyniki pomiaru barwy przedstawiono jako wartości trójchromatyczne w systemie $\mathrm{L}^{*} ; \mathrm{a}^{*} ; \mathrm{b}^{*}$, gdzie: L* - jasność metryczna, a* - barwa czerwono-zielona, $b^{*}$ - barwa żółtoniebieska. Wszystkie oznaczenia wykonano w dwóch powtórzeniach. Uzyskane wyniki poddano analizie statystycznej w programie STATISTICA za pomocą jednoczynnikowej analizy wariancji. Istotność różnic między średnimi wyznaczono testem NIR-Fishera. Jako poziom istotności statystycznej przyjęto $\mathrm{p} \leq 0,05$ i $\mathrm{p} \leq 0,01$.

Tabela 2. Charakterystyka badanych produktów

\begin{tabular}{|c|c|c|}
\hline Produkt & Składniki & $\begin{array}{l}\text { Wartość odżywcza produktu } \\
\text { w } 100 \text { g produktu }\end{array}$ \\
\hline $\begin{array}{l}\text { Zsiadłe mleko } \\
\text { OSM Krasnystaw } \\
\text { Produkt wyróżniony zna- } \\
\text { kiem „Jakość Tradycja” }\end{array}$ & $\begin{array}{l}\text { mleko } \\
\text { żywe kultury bakterii mleko- } \\
\text { wych }\end{array}$ & $\begin{array}{l}\text { wartość energetyczna: } 233 \mathrm{~kJ} / \\
56 \text { kcal } \\
\text { - tłuszcz: } 3,0 \mathrm{~g} \text {, w tym kwasy } \\
\text { tłuszczowe: } 1,9 \mathrm{~g} \\
\text { - węglowodany: } 4,3 \mathrm{~g} \text {, w tym } \\
\text { cukry: } 3,6 \mathrm{~g} \\
\text { - białko: } 2,9 \mathrm{~g} \\
\text { - sól: } 0,08 \mathrm{~g}\end{array}$ \\
\hline $\begin{array}{l}\text { Zsiadłe mleko OSM Piaski } \\
\text { Produkt wyróżniony zna- } \\
\text { kiem „Jakość Tradycja” }\end{array}$ & $\begin{array}{l}\text { mleko pasteryzowane } \\
\text { kultury bakterii mlekowych }\end{array}$ & $\begin{array}{l}\text { - wartość energetyczna: } 202 \mathrm{~kJ} / \\
48 \mathrm{kcal} \\
\text { - tłuszcz: } 2,0 \mathrm{~g}, \mathrm{w} \text { tym kwasy } \\
\text { tłuszczowe: } 1,5 \mathrm{~g} \\
\text { - węglowodany: } 4,3 \mathrm{~g}, \mathrm{w} \text { tym } \\
\text { cukry: } 3,6 \mathrm{~g} \\
\text { - białko: } 3,1 \mathrm{~g} \\
\text { - sól: } 0,10 \mathrm{~g}\end{array}$ \\
\hline Zsiadłe mleko SM Mlekovita & $\frac{\text { mleko }}{\text { kultury bakterii mlekowych }}$ & $\begin{array}{l}\text { wartość energetyczna: } 212 \mathrm{~kJ} / \\
50 \text { kcal } \\
\text { - tłuszcz: } 2,0 \mathrm{~g} \text {, w tym kwasy } \\
\text { thuszczowe: } 1,2 \mathrm{~g} \\
\text { - węglowodany: } 4,8 \mathrm{~g} \text {, w tym } \\
\text { cukry: } 4,8 \mathrm{~g} \\
\text { - białko: } 3,3 \mathrm{~g} \\
\text { - sól: } 0,10 \mathrm{~g}\end{array}$ \\
\hline Zsiadłe mleko SM Mlekpol & $\frac{\text { mleko }}{\text { kultury bakterii mlekowych }}$ & $\begin{array}{l}\text { - wartość energetyczna: } 244 \mathrm{~kJ} / \\
58 \mathrm{kcal} \\
\text { - tłuszcz: } 3,0 \mathrm{~g}, \mathrm{w} \text { tym kwasy } \\
\text { tłuszczowe: } 2,0 \mathrm{~g} \\
\text { - węglowodany: } 3,9 \mathrm{~g} \text {, w tym } \\
\text { cukry: } 3,9 \mathrm{~g} \\
\text { - białko: } 3,4 \mathrm{~g} \\
\text { - sól: } 0,10 \mathrm{~g}\end{array}$ \\
\hline
\end{tabular}


Wyniki dotyczące oceny fizykochemicznej zsiadłego mleka przedstawiono w tabeli 3 . Kwasowość czynna badanych produktów pochodzących z produkcji masowej była istotnie wyższa $(\mathrm{p} \leq 0,01)$ niż produktów wyróżnionych znakiem „Jakość Tradycja”. Kwasowość produktów jednostkowych w grupach oznaczonych znakiem i bez znaku jakości przyjmowała zbliżone wartości.

Kwasowość miareczkowa zsiadłego mleka powinna mieścić się w przedziale 25-45 ${ }^{\circ} \mathrm{SH}$. Wśród ocenianych produktów wymagania normy spełniły wszystkie badane produkty. Zaobserwowano jednak, że kwasowość miareczkowa zsiadłego mleka z produkcji masowej była istotnie niższa $(\mathrm{p} \leq 0,05)$ niż produktów ze znakiem jakości.

W przypadku zawartości kwasu mlekowego oraz aktywności wody w badanych produktach nie stwierdzono różnic istotnych statystycznie. Poziom kwasu mlekowego w produktach pochodzących z produkcji masowej przyjmował wartości poniżej $0,7 \%$.

Tabela 3. Wyniki oceny fizykochemicznej zsiadłego mleka $(\bar{x} \pm \mathrm{SD})$

\begin{tabular}{|c|c|c|c|c|}
\hline Produkt & $\mathrm{pH}$ & ${ }^{\circ} \mathrm{SH}$ & $\begin{array}{c}\text { Kwas mlekowy } \\
{[\%]}\end{array}$ & Aw \\
\hline $\begin{array}{l}\text { Zsiadłe mleko } \\
\text { Krasnystaw (zmz) }\end{array}$ & $4,44 \pm 0,11$ & $32,2 \pm 2,11$ & $0,73 \pm 0,09$ & $0,933 \pm 0,011$ \\
\hline $\begin{array}{l}\text { Zsiadłe mleko } \\
\text { Piaski (zmz) }\end{array}$ & $4,40 \pm 0,09$ & $34,4 \pm 2,41$ & $0,78 \pm 0,10$ & $0,915 \pm 0,013$ \\
\hline $\begin{array}{l}\text { Zsiadłe mleko } \\
\text { Mlekovita (zmm) }\end{array}$ & $4,27 \pm 0,12$ & $29,8 \pm 1,17$ & $0,67 \pm 0,09$ & $0,953 \pm 0,09$ \\
\hline $\begin{array}{l}\text { Zsiadłe mleko } \\
\text { Mlekpol (zmm) }\end{array}$ & $4,23 \pm 0,08$ & $30,8 \pm 0,91$ & $0,69 \pm 0,07$ & $0,915 \pm 0,013$ \\
\hline $\bar{x}_{\mathbf{z m z}}$ & $4,42^{B} \pm 0,10$ & $33,0^{b} \pm 2,35$ & $0,74 \pm 0,09$ & $0,925 \pm 0,011$ \\
\hline $\bar{x}_{\mathbf{z m m}}$ & $4,25^{\mathrm{A}} \pm 0,11$ & $29,8^{a} \pm 1.04$ & $\mathbf{0 , 6 7} \pm \mathbf{0 , 0 8}$ & $0,926 \pm 0,013$ \\
\hline
\end{tabular}

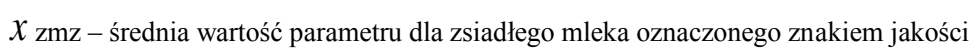

$-$

$x$ zmm - średnia wartość parametru dla zsiadłego mleka z produkcji masowej

$\mathrm{A}, \mathrm{B}$ - różnice między średnimi istotne przy $\mathrm{p} \leq 0,01$

$\mathrm{a}, \mathrm{b}$ - różnice między średnimi istotne przy $\mathrm{p} \leq 0,05$

Analizując wyniki badań dotyczących barwy zsiadłego mleka (tab. 4) wykazano, że ich jasność była na podobnym poziomie $(83,30-84,45)$. Najwyższym udziałem barwy zielonej charakteryzowało się zsiadłe mleko SM Mlekovita $(-1,78)$. Mleko z produkcji masowej wykazywało istotnie $(\mathrm{p} \leq 0,01)$ wyższy udział barwy żółtej $(7,54)$. 
Tabela 4. Parametry barwy zsiadłego mleka $\left(\bar{x}_{ \pm \mathrm{SD}}\right)$

\begin{tabular}{|l|c|c|c|}
\hline \multicolumn{1}{|c|}{ Produkt } & $\mathrm{L}^{*}$ & $\mathrm{a}^{*}$ & $\mathrm{~b}^{*}$ \\
\hline $\begin{array}{l}\text { Zsiadłe mleko } \\
\text { Krasnystaw (zmz) }\end{array}$ & $84,45 \pm 0,31$ & $-1,45 \pm 0,12$ & $6,79 \pm 0,24$ \\
\hline $\begin{array}{l}\text { Zsiadłe mleko } \\
\text { Piaski (zmz) }\end{array}$ & $83,96 \pm 0,23$ & $-1,61 \pm 0,09$ & $7,17 \pm 0,17$ \\
\hline $\begin{array}{l}\text { Zsiadłe mleko } \\
\text { Mlekovita (zmm) }\end{array}$ & $83,30 \pm 0,74$ & $-1,78 \pm 0,26$ & $7,43 \pm 0,11$ \\
\hline $\begin{array}{l}\text { Zsiadłe mleko } \\
\text { Mlekpol (zmm) }\end{array}$ & $84,28 \pm 0,52$ & $-1,38 \pm 0,14$ & $7,63 \pm 0,09$ \\
\hline $\begin{array}{l}\bar{x} \\
\text { zmz }\end{array}$ & $\mathbf{8 4 , 2 2} \pm \mathbf{0 , 3 4}$ & $-\mathbf{1 , 5 4} \pm \mathbf{0 , 1 1}$ & $\mathbf{7 , 0 0} \mathbf{A}^{\mathbf{A}} \pm \mathbf{0 , 2 6}$ \\
\hline- & $\mathbf{8 3 , 8 0} \pm \mathbf{0 , 6 9}$ & $\mathbf{- 1 , 5 9} \pm \mathbf{0 , 2 9}$ & $\mathbf{7 , 5 4} \mathbf{B}^{\mathbf{B}} \pm \mathbf{0 , 1 3}$ \\
\hline
\end{tabular}

$x$ zmz - średnia wartość parametru zsiadłego mleka oznaczonego znakiem jakości

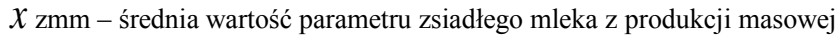

$\mathrm{A}, \mathrm{B}$ - różnice między średnimi istotne przy $\mathrm{p} \leq 0,01$

Produkty fermentowane poddano również ocenie organoleptycznej wg 5-punktowej skali. Oceniono ich smak, zapach, barwę i konsystencję. Produkty testowało 10 wcześniej odpowiednio przeszkolonych osób. Każdy z degustatorów oceniał produkty według skali od 1 do 5 . Skala ta obejmowała 5 poziomów jakości: 5 bardzo dobra; 4 - dobra; 3 - dostateczna; 2 - niedostateczna; 1 - zła. Uzyskane wyniki przedstawiono na rycinie 1 .

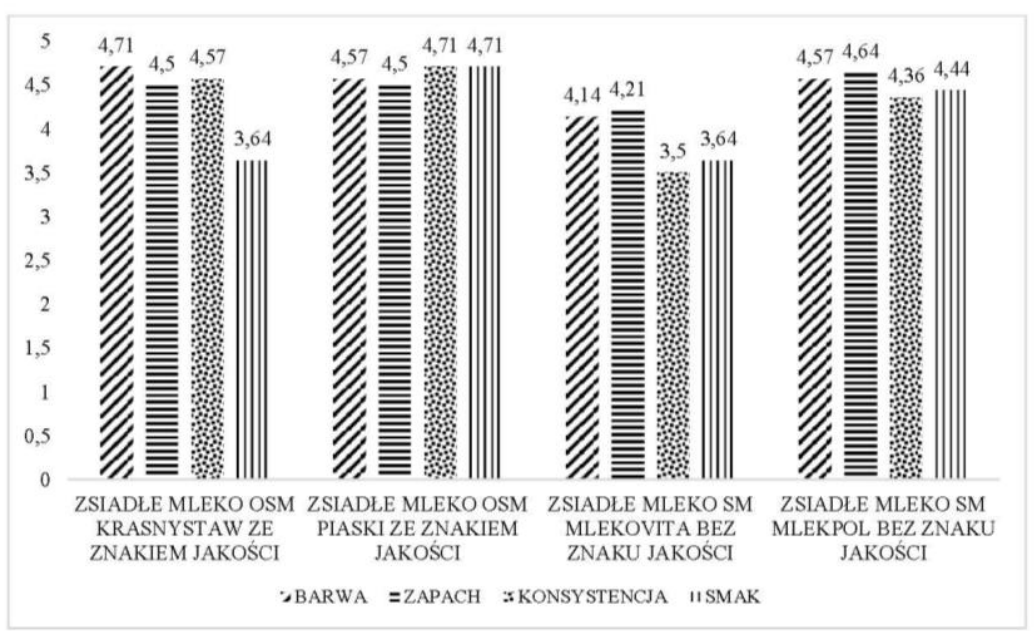

Ryc. 1. Wyniki oceny organoleptycznej zsiadłego mleka 
Produkty były zróżnicowane jakościowo pod względem ocenianych cech. Najkorzystniej oceniono smak i konsystencję produktu wyróżnionego znakiem jakości z OSM Piaski (po 4,71 pkt). Wg degustatorów najbardziej pożądaną barwą charakteryzował się również produkt ze znakiem jakości (OSM Krasnystaw, 4,71 pkt). W ocenie instrumentalnej barwy tego produktu stwierdzono najniższy udział barwy zielonej $\left(\mathrm{a}^{*}-1,45\right)$ i żółtej $\left(\mathrm{b}^{*} 6,79\right)$. Za zapach z kolei najwyższą ilość punktów uzyskał produkt z Mlekpolu (bez znaku jakości). Z najniższym uznaniem degustatorów spotkał się produkt z SM Mlekovita. Niskie noty za barwę produktu można łączyć z najwyższym udziałem barwy zielonej $\left(a^{*}-1,78\right)$ i żółtej $\left(b^{*} 7,43\right)$. Smak tego produktu oceniono na 3,64 pkt, podobnie jak zsiadłego mleka z Krasnegostawu. Można stwierdzić, że w ocenie organoleptycznej badanych produktów mlecznych wyróżnienie znakiem „Jakość Tradycja" miało przełożenie na noty degustatorów.

\section{Bibliografia}

Baranowska M., 2009. Właściwości fizykochemiczne kefiru i biokefiru, Inżynieria i Aparatura Chem., 48, 2, 18-20.

Czerwińska D., 2012. Uczta jogurtowa, Przegl. Gastron., 7-8.

Danków R., Teichert J., Pikul J., Osten-Sacken N., 2013. Właściwości napojów fermentowanych wytworzonych z modyfikowanego mleka krowiego, Nauka Przyroda Technologie. UP w Poznaniu, 4, 1-9.

Gawęcki J., Mossor-Pietraszewska T., red., 2006. Kompendium wiedzy o żywności, żywieniu i zdrowiu, Wyd. Nauk. PWN, Warszawa, 254.

Gąsiorowski M., 2005. O produktach tradycyjnych i regionalnych. Możliwości a polskie realia Fund. Funduszu Współpracy, Warszawa.

Haska A., Martyniuk E., 2019. Wybrane metody wyróżniania produktów spożywczych na rynku, Żywność. Nauka. Technologia. Jakość, 26, 2 (119), 18-31.

Kieljan K., 2011. O systemach jakości żywności. Vademecum funkcjonowanie produktów regionalnych i tradycyjnych. Centrum Doradztwa Rolniczego w Brwinowie, Oddział w Krakowie, Kraków.

Kokotkiewicz J., Radzik-Rant A., Rant W., 2018. Produkty pochodzenia owczego w systemach jakości żywności, Wiad. Zootech., 56, 2:, 85-92.

Koluch P., Marchewka M., 2009. Jogurtu historia naturalna, Kuchnia. Magazyn dla Smakoszy, 5, $62-67$.

Król J., Brodziak A., 2016. Mleczne napoje fermentowane właściwości prozdrowotne, Przemysł Spożywczy, 10, 22-28.

Krzyżewski J., Rynkiewicz Z., Strzałkowska N., 1997. Kwasowość jako kryterium oceny jakości mleka. Przegl. Hodowl., 65, 10, 10-11.

Kudełka W., 2005. Charakterystyka mlecznych napojów fermentowanych w Unii Europejskiej oraz w Polsce, Zesz. Nauk. Akad.Ekon. w Krakowie, 678, 149-160.

Kukułowicz A., 2017. Aspekty zdrowotne i jakość mikrobiologiczna zsiadłego mleka, Bromatologia Chemia Toksykologia, 3, 227-233.

Litwińczuk Z. (red.), 2011. Towaroznawstwo surowców i produktów zwierzęcych z podstawami przetwórstwa, PWRiL, Warszawa.

Modrzyńska J., 2018. System ochrony produktów regionalnych i tradycyjnych w Unii Europejskiej, Zesz. Nauk. Polit. Śląskiej, 129, 281-295. 
Mojka K., 2013. Charakterystyka mlecznych napojów fermentowanych, Probl. Hig. Epidem., 94, $722-729$.

Nadolna I., Kunachowicz K., 2005. Napoje mleczne fermentowane i ich znaczenie prozdrowotne. Przegl. Mleczarski, 7, 289-29.

Nowak M., Trziszka T., Szołtysik M., 2007. Preferencje konsumentów mlecznych napojów fermentowanych. Żywność. Nauka. Technologia. Jakość, 1 (50), 77-83.

PN-A-86061:2002; Mleko i przetwory mleczne - Mleko fermentowane. PKN, Warszawa.

Soregaroli C., Boccaletti S., Moro D., 2003. Consumer's attitude towards labelled and unlabeled GM food products in Italy. Intern. Food Agribus.s Manag.t Rev., 6, 111-127.

Turek K., Wszołek M., Domagała J., 2019. Kefir pod lupą. Przem. Spoż., 73, 48-53.

Vecchio R., Annunziata A., 2011. The role of PDO/PGI labelling in Italian consumers' food choices. Agric. Econ. Rev. 12 (2), 80-98.

Ziółkowski T., 2012. Możliwości zastosowania szczepów o właściwościach probiotycznych w produkcji jogurtów, Przegl. Mleczarski, 3, 12-15.

Żelazowski P., 2015. Życie w mlecznych napojach fermentowanych, Życie interdyscyplinarnie, Wyd. Diecezji Siedleckiej UNITAS, 1, 212-233. 


\section{Joanna Jędrusyna ${ }^{1,3}$, Karolina Król ${ }^{1}$, Magdalena Stobiecka ${ }^{2}$, Aleksandra Krochmal ${ }^{1}$, Barbara Topyła ${ }^{2}$}

\section{Zmiany jakości mleka spożywczego podczas przechowywania}

Changes in the quality of drinking milk during storage

Mleko jest niezwykle ważnym elementem w diecie każdego człowieka. Stanowi bogate źródło białka, tłuszczu, witamin, związków mineralnych i wielu innych elementów niezbędnych do prawidłowego rozwoju. Jest jednym z ważniejszych wyrobów w produkcji polskich zakładów mleczarskich. W zależności od rodzaju zastosowanej obróbki cieplnej oferowane jest konsumentom jako mleko pasteryzowane, pasteryzowane w wysokiej temperaturze lub UHT. Stosunkowo nową formą jest mleko wytwarzane w technologii ESL, polegającej na połączeniu procesu mikrofiltracji i pasteryzacji w niskiej temperaturze [Dec 2011]. Stosowanie obróbki cieplnej ma na celu zapewnienie bezpieczeństwa zdrowotnego produktu i zwiększenie jego trwałości. Trwałość i jakość mleka spożywczego jest warunkowana przede wszystkim jakością surowca, rodzajem zastosowanej obróbki cieplnej, jak również warunkami i czasem przechowywania. Ważne jest, aby zapewnić odpowiednie warunki podczas przechowywania i transportowania mleka spożywczego, gdyż niezachowanie łańcucha chłodniczego może doprowadzić do obniżenia jego jakości [Brodziak i in. 2017a].

\section{Mleko pasteryzowane}

Pasteryzacja mleka ma na celu całkowite zniszczenie mikroflory chorobotwórczej oraz zminimalizowanie liczby mikroorganizmów saprofitycznych mogących powodować jego zepsucie. Mleko surowe poddawane jest ogrzewaniu w temperaturze nieprzekraczającej $100^{\circ} \mathrm{C}$, przez okres gwarantujący całkowite zniszczenie form chorobotwórczych [Ziajka 2008]. Zgodnie z Rozporządzeniem Komisji (WE) nr 1662/2006 z dnia 6 listopada 2006 r. [Dz. U. L 320/1] produkcję mleka pasteryzowanego przeprowadza się za pomocą obróbki cieplnej polegającej na stosowaniu: wysokiej temperatury w krótkim przedziale czasowym

\footnotetext{
${ }^{1}$ SKN Nauk o Zwierzętach i Biogospodarki, Sekcja Towaroznawstwa i Bezpieczeństwa Żywności, Wydział Nauk o Zwierzętach i Biogospodarki, Uniwersytet Przyrodniczy w Lublinie

${ }^{2}$ Instytut Oceny Jakości i Przetwórstwa Produktów Zwierzęcych, Wydział Nauk o Zwierzętach i Biogospodarki, Uniwersytet Przyrodniczy w Lublinie

${ }^{3}$ e-mail: asia.1709@o2.pl
} 
(co najmniej $72^{\circ} \mathrm{C}$ przez 15 sek.); niskiej temperatury w długim przedziale czasowym (co najmniej $63^{\circ} \mathrm{C}$ przez $30 \mathrm{~min}$ ) lub innej kombinacji warunków czasowych i termicznych w celu uzyskania równoważnego rezultatu, tak aby bezpośrednio po obróbce produkty wykazywały ujemną reakcję w badaniu na obecność fosfatazy alkalicznej.

Skuteczny proces pasteryzacji niszczy 99\% mikroorganizmów saprofitycznych oraz $100 \%$ mikroorganizmów chorobotwórczych. Mikroflorę przeżywającą proces pasteryzacji tworzą głównie mikrokoki i mikrobakterie, przetrwalnikujące i nieprzetrwalnikujące bakterie ciepłooporne oraz psychrotrofy. Wywołują one psucie mleka pasteryzowanego poprzez ukwaszenie i nadanie posmaku thuszczowego, nieczystego i lekko gorzkiego [Jakubczyk i Bogdańska-Zaręba 2009]. Podstawowym czynnikiem selekcjonującym bakterie przeżywające proces pasteryzacji jest temperatura. $\mathrm{W}$ wyniku ogrzewania $\mathrm{w} 72^{\circ} \mathrm{C} \mathrm{w}$ mleku pozostają bakterie $\mathrm{z}$ rodziny Enterococcus, Acinetobacter, Streptococcus, większość Lactobacillus oraz ciepłooporne bakterie przetrwalnikujące i nieprzetrwalnikujące. Natomiast ogrzewanie w temperaturze $85^{\circ} \mathrm{C}$ wytrzymują tylko niektóre mikrobakterie i przetrwalniki Bacillus i Clostridium, zaś w mleku ogrzanym do temperatury powyżej $90^{\circ}$ pozostają jedynie przetrwalniki [Ziarno i Czapska 2008].

Efektywność pasteryzacji wzrasta wraz z podwyższeniem temperatury oraz wydłużeniem czasu procesu. Istotnym aspektem $\mathrm{w}$ procesie pasteryzacji jest zatem ustalenie odpowiednich parametrów, zapewniających skuteczność degradacji mikroorganizmów chorobotwórczych, przy minimalnych zmianach jego właściwości biologicznych, fizykochemicznych oraz zmianach jego smaku. Mleko utrwalone tą metodą przy zapewnieniu chłodniczych warunków w czasie transportu i przechowywania zachowuje przydatność do spożycia przez kilka dni [Sałacki 2011]. Czas przydatności spożywczej mleka pasteryzowanego zależy od kilku czynników, m.in. parametrów procesu, składu mikroflory przeżywającej obróbkę cieplną, temperatury przechowywania [Jakubczyk i Bogdańska-Zaręba 2009]. Z punktu widzenia trwałości mleka pasteryzowanego kluczowe jest zapewnienie chłodniczych warunków przechowywania, tj. utrzymywanie temperatury na poziomie nie wyższym niż $7^{\circ} \mathrm{C}$. Zakłada się, że wzrost temperatury o $2^{\circ} \mathrm{C}$ skutkuje skróceniem czasu trwałości o połowę [Pluta 2013].

\section{Mleko UHT}

Mleko UHT (Ultra High Temperature) jest podstawowym produktem spożywczym na krajowym rynku, zajmuje wysoką pozycję i charakteryzuje się wysokim spożyciem wśród społeczeństwa [Wroński i Rzemieniewski 2009]. Zgodnie z Rozporządzeniem Komisji (WE) nr 1662/2006 z dnia 6 listopada 2006 r. [Dz. U. L 320/1], produkcję mleka UHT (ang. Ultra High Temperature) przeprowadza się za pomocą obróbki obejmującej ciągły przepływ ciepła o wysokiej temperaturze w krótkim przedziale czasowym (nie mniej niż $135^{\circ} \mathrm{C}$ w połączeniu z odpowiednim czasem utrzymywania się), tak aby w produkcie, który został poddany obróbce $\mathrm{i}$ jest przechowywany $\mathrm{w}$ zamkniętym aseptycznym pojemniku 
w temperaturze otoczenia, nie występowały zdolne do przeżycia mikroorganizmy lub przetrwalniki zdolne do wzrostu; oraz wystarczającej do zagwarantowania, że produkty zachowują stabilność mikrobiologiczną po inkubacji przez $15 \mathrm{dni}$ w temperaturze $30^{\circ} \mathrm{C}$ w zamkniętych pojemnikach lub przez 7 dni w temperaturze $55^{\circ} \mathrm{C}$ w zamkniętych pojemnikach.

Powszechnie stosuje się sterylizację UHT, która polega na poddaniu mleka działaniu temperatury wynoszącej minimum $135^{\circ} \mathrm{C}$ przez bardzo krótki czas (zwykle kilka sekund) [Walstra i in. 2006]. Poddanie mleka obróbce UHT pozwala na uzyskanie pożądanego stopnia zniszczenia mikroorganizmów i ich enzymów przy minimalnych niekorzystnych zmianach cech fizykochemicznych i sensorycznych oraz, co najważniejsze, bez obniżania wartości odżywczej produktu [Popov-Ralijć i in. 2008, Brodziak i in. 2017a].

Proces sterylizacji UHT powinien zagwarantować uzyskanie ściśle określonego stopnia zanieczyszczenia mikroflory w mleku oraz inaktywacji większości enzymów przy pojawieniu się jak najmniejszych zmian cech organoleptycznych i fizykochemicznych. Mleko UHT jest całkowicie pozbawione wszelkich form drobnoustrojów oraz ich form przetrwalnikujących. Czynnikiem warunkującym jego trwałość jest odpowiednie pakowanie do sterylnych opakowań w równie sterylnych warunkach [Sumińska i Dmytrów 2015]. Wysokie temperatury powodują minimalne zmiany w komponentach mleka. Zmiany te są tym większe, im wyższy jest zakres temperatur i dłuższy czas ich reakcji na mleko. Składniki takie jak kazeina czy thuszcz nie ulegają znaczącym zmianom. Ogrzewanie w wysokich temperaturach prowadzi do osadzania się części zdenaturowanych białek serwatkowych w roztworze, a część zostaje na powierzchniach grzejnych. Denaturacja białek nie obniża jednak poziomu wartości odżywczej mleka. Wysokie temperatury powodują również niewielkie straty fosforanów wapnia, jak również prowadzą do zmian zapachu i smaku mleka. Charakterystyczny zapach gotowania jest skutkiem reakcji między grupami karbonylowymi cukrów, a grupami aminowymi białek tzw., reakcja Maillarda, natomiast zapach karmelu powstaje na skutek zmian laktozy [Ziajka 2008].

Główną zaletą mleka UHT jest najdłuższy spośród wszystkich rodzajów mleka spożywczego termin przydatności do spożycia. Wynosi on nawet do kilku miesięcy (w przypadku zamkniętych opakowań). Kolejnym atutem jest to, że podczas przechowywania nie wymaga warunków chłodniczych [Sałacki 2011].

\section{Mleko ESL}

Alternatywą dla metod sterylizacji i pasteryzacji może być mleko spożywcze produkowane w technologii ESL (Extended Shelf Life), które zachowuje swoją trwałość przez kilka tygodni, przy zachowaniu odpowiednich warunków łańcucha chłodniczego. Ogólnie przyjmuje się, że termin „mleko ESL” oznacza mleko wytworzone z zastosowaniem technik pozwalających na zapewnienie dłuższego okresu przydatności do spożycia niż pasteryzacja oraz niepowodujących negatywnego wpływu na cechy organoleptyczne [Dec 2011]. Obecnie stosowaną 
techniką ESL jest połączenie mikrofiltracji (MF) i pasteryzacji w niskiej temperaturze (nie wyższej niż $75^{\circ} \mathrm{C}$ ). Mikrofiltracja jest procesem membranowej separacji, dzięki czemu drobnoustroje są w znacznym stopniu wyeliminowane z mleka odtłuszczonego. Spadek poziomu białka po procesie mikrofiltracji nie powinien być wyższy niż 0,03 pkt procentowego. Mikrofiltracja oprócz utrwalanie mleka pozwala również osiągnąć 2-tygodniową trwałość w warunkach przechowywania $10^{\circ} \mathrm{C}$, jak też 5 tygodni w temperaturze $6^{\circ} \mathrm{C}$. Zmniejszenie poziomu mikroflory wynosi 3-4 cykle logarytmiczne [Muszalska 2006, Śmietana i in. 2007].

Technologie ESL są to rozwiązania, które wymagają szczególnej uwagi w każdym aspekcie produkcyjnym, począwszy od selekcji mleka surowego o wysokiej jakości, a kończąc na odpowiednio zachowanym łańcuchu chłodniczym wraz z odpowiednimi warunkami transportu i dystrybucji. Aby wyprodukować najwyższej jakości mleko ESL, zalecane jest zastosowanie mleka surowego o niskiej początkowej liczbie bakterii, nieprzekraczającej 100 tys. jtk/l. Technologia ta stanowi odpowiedni przykład, gdzie jakość surowca oraz cała droga jego przetwarzania, tzn. wpływ warunków przechowywania, pakowania i dystrybucji, odgrywają kluczową rolę w otrzymaniu najwyższej jakości produktu [Śmietana i in. 2007].

\section{Cel pracy}

Celem pracy była ocena jakości sensorycznej mleka UHT zakupionego na rynku lubelskim podczas dziesięciodniowego przechowywania w warunkach chłodniczych po otwarciu opakowania.

Zgodnie z informacją podaną przez producenta na opakowaniu mleko UHT po otwarciu można przechowywać w warunkach chłodniczych nie dłużej niż 48 godz. Bardzo często klienci nie przestrzegają tych zaleceń, spożywając mleko po upływie tego czasu.

\section{Material i metody}

Materiał do badań stanowiły próbki mleka UHT od 9 producentów (A, B, C, D, E, F, G, H, I), w tym 4 marki własne sieci handlowych (D, G, H. I), zakupione na rynku lubelskim. Charakterystykę materiału badawczego przedstawiono w tabeli 1 . Wszystkie zakupione próby mleka były w opakowaniach kartonowych Tetra Brik Aseptic.

Mleko zostało otwarte w dniu rozpoczęcia badań (dzień „0”), a następnie przechowywane $\mathrm{w}$ warunkach chłodniczych (w lodówce $\mathrm{w}$ temp. $4-6^{\circ} \mathrm{C}$ ) do momentu zakończenia badań. Każdą próbkę mleka w odstępach dwudniowych poddano ocenie sensorycznej przez 5-osobowy zespół, uprzednio przeszkolony. Przed oceną próbki były kodowane i umieszczane przez $1 \mathrm{~h}$ w temperaturze pokojowej. Badania wykonano w trzech powtórzeniach. 
Tabela 1. Charakterystyka materiału badawczego (wg informacji zawartych na opakowaniu)

\begin{tabular}{|c|c|c|c|}
\hline Oznaczenie & $\begin{array}{c}\text { Zawartość tłuszczu } \\
\mathrm{g} / 100 \mathrm{ml}\end{array}$ & $\begin{array}{c}\text { Zawartość białka } \\
\mathrm{g} / 100 \mathrm{ml}\end{array}$ & $\begin{array}{c}\text { Zawartość węglowodanów } \\
\mathrm{g} / 100 \mathrm{ml}\end{array}$ \\
\hline $\mathrm{A}$ & 2,0 & 3,0 & 4,7 \\
$\mathrm{~B}$ & 2,0 & 3,4 & 4,9 \\
$\mathrm{C}$ & 2,0 & 3,3 & 4,7 \\
$\mathrm{D}$ & 2,0 & 3,0 & 4,8 \\
$\mathrm{E}$ & 2,0 & 3,0 & 4,9 \\
$\mathrm{~F}$ & 2,0 & 3,0 & 4,9 \\
$\mathrm{G}$ & 2,0 & 3,3 & 4,7 \\
$\mathrm{H}$ & 2,0 & 3,3 & 4,8 \\
$\mathrm{I}$ & 2,0 & 3,0 & 4,7 \\
\hline
\end{tabular}

Próbki przedstawiano oceniającym wraz z kwestionariuszem oceny sensorycznej. Do oceny intensywności poszczególnych cech produktów, tj. smaku, zapachu, konsystencji i barwy zastosowano 5-punktową skalę, gdzie 1 oznaczało jakość dyskwalifikującą (nieodpowiednią), 5 - jakość bardzo dobrą (charakterystyczną dla produktu, naturalną). Oceniano również smak i zapach (z podziałem na: słodki, mleczny, gotowany, obcy) wykorzystując w tym przypadku skalę sześciopunktową, w której poszczególnej liczbie punktów przypisano następujące określenia słowne: 0 - niewyczuwalna/brak, 1 - bardzo słaba, 2 - słaba, 3 przeciętna, 4 - silna i 5 - bardzo silna [Baryłko-Piekielna i Matuszewska 2009].

\section{Omówienie wyników i dyskusja}

Mleko spożywcze najbardziej pożądane przez konsumenta powinno charakteryzować się barwą białą, która pozostaje na niezmienionym poziomie podczas dalszego przechowywania. W tabeli 2 przedstawiono wyniki dla barwy i konsystencji mleka podczas jego przechowywania po otwarciu opakowania. Stwierdzono, iż czas przechowywania mleka nie wpłynął istnie na jego barwę. Wszystkie próbki mleka, niezależnie od producenta i dnia przechowywania zostały ocenione bardzo wysoko, uzyskując średnio ocenę 5. Przez cały okres przechowywania barwa była biała, naturalna, charakterystyczna dla mleka spożywczego. Badania przeprowadzone przez Cais-Sokolińską i Pikula [2003] również nie wykazały zmian barwy mleka przechowywanego w temperaturze $4+/-1^{\circ} \mathrm{C}$ przez okres 20 tygodni. Natomiast po upływie 20 tygodni wraz z upływem okresu przechowywania barwa mleka była coraz bardziej żółta. Nasycenie barwy w kierunku żółtej następowało szybciej podczas przechowywania mleka w wyższych temperaturach. 
Tabela 2. Ocena barwy i konsystencji mleka UHT podczas przechowywania $(\bar{x} \pm \mathrm{SD})$

\begin{tabular}{|c|c|c|c|c|c|c|c|c|c|c|c|c|}
\hline \multirow{2}{*}{ Producent } & \multicolumn{6}{|c|}{ Barwa } & \multicolumn{6}{|c|}{ Konsystencja } \\
\hline & 0 & 2 & 4 & 6 & 8 & 10 & 0 & 2 & 4 & 6 & 8 & 10 \\
\hline A & $5 \pm 0,0$ & $5 \pm 0,0$ & $5 \pm 0,0$ & $5 \pm 0,0$ & $5 \pm 0,0$ & $5 \pm 0,0$ & $5 \pm 0,0$ & $5 \pm 0,0$ & $5 \pm 0,0$ & $5 \pm 0,0$ & $5 \pm 0,0$ & $5 \pm 0,0$ \\
\hline B & $5 \pm 0,0$ & $5 \pm 0,0$ & $5 \pm 0,0$ & $5 \pm 0,0$ & $5 \pm 0,0$ & $5 \pm 0,0$ & $5 \pm 0,0$ & $5 \pm 0,0$ & $5 \pm 0,0$ & $5 \pm 0,0$ & $5 \pm 0,0$ & $5 \pm 0,0$ \\
\hline $\mathrm{C}$ & $5 \pm 0,0$ & $5 \pm 0,0$ & $5 \pm 0,0$ & $5 \pm 0,0$ & $5 \pm 0,0$ & $5 \pm 0,0$ & $5 \pm 0,0$ & $5 \pm 0,0$ & $5 \pm 0,0$ & $5 \pm 0,0$ & $5 \pm 0,0$ & $5 \pm 0,0$ \\
\hline $\mathrm{D}$ & $5 \pm 0,0$ & $5 \pm 0,0$ & $5 \pm 0,0$ & $5 \pm 0,0$ & $5 \pm 0,0$ & $5 \pm 0,0$ & $5 \pm 0,0$ & $5 \pm 0,0$ & $5 \pm 0,0$ & $5 \pm 0,0$ & $5 \pm 0,0$ & $5 \pm 0,0$ \\
\hline $\mathrm{E}$ & $5 \pm 0,0$ & $5 \pm 0,0$ & $5 \pm 0,0$ & $5 \pm 0,0$ & $5 \pm 0,0$ & $5 \pm 0,0$ & $5 \pm 0,0$ & $5 \pm 0,0$ & $5 \pm 0,0$ & $5 \pm 0,0$ & $5 \pm 0,0$ & $5 \pm 0,0$ \\
\hline $\mathrm{F}$ & $5 \pm 0,0$ & $5 \pm 0,0$ & $5 \pm 0,0$ & $5 \pm 0,0$ & $5 \pm 0,0$ & $5 \pm 0,0$ & $5 \pm 0,0$ & $5 \pm 0,0$ & $5 \pm 0,0$ & $5 \pm 0,0$ & $5 \pm 0,0$ & $5 \pm 0,0$ \\
\hline G & $5 \pm 0,0$ & $5 \pm 0,0$ & $5 \pm 0,0$ & $5 \pm 0,0$ & $5 \pm 0,0$ & $5 \pm 0,0$ & $5 \pm 0,0$ & $5 \pm 0,0$ & $5 \pm 0,0$ & $5 \pm 0,0$ & $5 \pm 0,0$ & $5 \pm 0,0$ \\
\hline $\mathrm{H}$ & $5 \pm 0,0$ & $5 \pm 0,0$ & $5 \pm 0,0$ & $5 \pm 0,0$ & $5 \pm 0,0$ & $5 \pm 0,0$ & $5 \pm 0,0$ & $5 \pm 0,0$ & $5 \pm 0,0$ & $5 \pm 0,0$ & $5 \pm 0,0$ & $4,5 \pm 0,5$ \\
\hline I & $5 \pm 0,0$ & $5 \pm 0,0$ & $5 \pm 0,0$ & $5 \pm 0,0$ & $5 \pm 0,0$ & $5 \pm 0,0$ & $5 \pm 0,0$ & $5 \pm 0,0$ & $5 \pm 0,0$ & $5 \pm 0,0$ & $5 \pm 0,0$ & $5 \pm 0,0$ \\
\hline
\end{tabular}


Tabela 3. Ocena smaku i zapachu mleka UHT podczas przechowywania $(\bar{x} \pm \mathrm{SD})$

\begin{tabular}{|c|c|c|c|c|c|c|c|c|c|c|c|c|}
\hline \multirow{2}{*}{ Producent } & \multicolumn{6}{|c|}{ Zapach } & \multicolumn{6}{|c|}{ Smak } \\
\hline & 0 & 2 & 4 & 6 & 8 & 10 & 0 & 2 & 4 & 6 & 8 & 10 \\
\hline A & $4 \pm 0,7$ & $4 \pm 0,7$ & $4 \pm 1,0$ & $4 \pm 1,0$ & $4 \pm 0,7$ & $4 \pm 1,0$ & $4,3 \pm 0,56$ & $4,2 \pm 0,45$ & $4,2 \pm 0,45$ & $4,2 \pm 0,45$ & $4,2 \pm 0,45$ & $4,2 \pm 0,45$ \\
\hline B & $4 \pm 0,7$ & $4 \pm 0,0$ & $4 \pm 0,7$ & $4 \pm 1,0$ & $4 \pm 0,7$ & $4 \pm 0,7$ & $5 \pm 0,0$ & $5 \pm 0,0$ & $5 \pm 0,0$ & $5 \pm 0,0$ & $5 \pm 0,0$ & $5 \pm 0,0$ \\
\hline $\mathrm{C}$ & $5 \pm 0,0$ & $5 \pm 0,0$ & $5 \pm 0,0$ & $5 \pm 0,0$ & $5 \pm 0,0$ & $5 \pm 0,0$ & $4,7 \pm 0,44$ & $4,7 \pm 0,44$ & $4,7 \pm 0,44$ & $4,6 \pm 0,54$ & $4,7 \pm 0,44$ & $4,6 \pm 0,68$ \\
\hline $\mathrm{D}$ & $3 \pm 0,7$ & $3 \pm 0,7$ & $3 \pm 0,0$ & $3 \pm 0,0$ & $2,8 \pm 0,45$ & $2,2 \pm 0,84$ & $4 \pm 0,0$ & $4 \pm 0,0$ & $4 \pm 0,0$ & $4 \pm 0,0$ & $4 \pm 0,0$ & $3,6 \pm 0,55$ \\
\hline E & $4 \pm 0,7$ & $4 \pm 0,0$ & $4 \pm 0,0$ & $4 \pm 0,7$ & $4 \pm 1,0$ & $4 \pm 1,0$ & $4,7 \pm 0,44$ & $4,7 \pm 0,44$ & $4,7 \pm 0,44$ & $4,7 \pm 0,54$ & $4,7 \pm 0,44$ & $4,7 \pm 0,58$ \\
\hline $\mathrm{F}$ & $4 \pm 1,0$ & $3,9 \pm 0,22$ & $3,9 \pm 0,22$ & $4 \pm 1,0$ & $3,9 \pm 0,22$ & $3,9 \pm 0,22$ & $4,6 \pm 0,68$ & $4,6 \pm 0,84$ & $4,6 \pm 0,44$ & $4,6 \pm 0,68$ & $4,6 \pm 0,44$ & $4,6 \pm 0,68$ \\
\hline G & $3,8 \pm 0,45$ & $3,8 \pm 0,45$ & $3,8 \pm 0,45$ & $3,8 \pm 0,45$ & $3,8 \pm 0,45$ & $3,8 \pm 0,45$ & $4,4 \pm 0,42$ & $4,4 \pm 0,42$ & $4,4 \pm 0,42$ & $4,3 \pm 0,45$ & $4,3 \pm 0,45$ & $4,3 \pm 0,45$ \\
\hline $\mathrm{H}$ & $3 \pm 0,7$ & $3 \pm 0,7$ & $3 \pm 1,0$ & $2,9 \pm 0,68$ & $2,9 \pm 0,68$ & $2,8 \pm 0,84$ & $4 \pm 0,0$ & $4 \pm 0,7$ & $4 \pm 1,0$ & $4 \pm 1,0$ & $4 \pm 1,0$ & $3,6 \pm 0,55$ \\
\hline I & $4 \pm 0,7$ & $4 \pm 0,7$ & $4 \pm 0,0$ & $4 \pm 0,7$ & $4 \pm 0,7$ & $4 \pm 0,7$ & $4,7 \pm 0,44$ & $4,7 \pm 0,44$ & $4,7 \pm 0,44$ & $4,6 \pm 0,54$ & $4,6 \pm 0,68$ & $4,6 \pm 0,68$ \\
\hline
\end{tabular}


Próbki mleka pod względem konsystencji podczas 10-dniowego przechowywania były-oceniane również bardzo wysoko (ocena 5). Jedynie w przypadku mleka $\mathrm{H}$ w ostatnim dniu przechowywania zanotowano niższe oceny $\mathrm{z}$ uwagi na wzrost lepkości mleka, co może być spowodowane zachodzącymi reakcjami enzymatycznymi lub zmianami fizykochemicznymi. Usarek i Węgrzynowski [1997] wykazali, że mleko UHT może ulec żelifikacji oraz zmianie lepkości w relatywnie krótkim czasie przechowywania. Zmiany te spowodowane są najczęściej proteolizą, podczas której dochodzi do rozkładu kazeiny, a przede wszystkim jej frakcji $\beta$. Niekorzystne zmiany w konsystencji mleka, głównie jego galaretowacenie, zachodzą $\mathrm{w}$ wyższych temperaturach przechowywania. Należy jednak pamiętać, że już temperatura powyżej $6^{\circ} \mathrm{C}$ zdecydowanie przyspiesza tempo niekorzystnych zmian konsystencji. Dlatego też, aby zachować wysoką jakość mleka UHT, należy je po otwarciu przechowywać w odpowiednich warunkach chłodniczych.

Smak i zapach mleka degustatorzy ocenili zdecydowanie gorzej w porównaniu z jego barwą i konsystencją. Najwyższej oceniono smak mleka B, przyznając mu ocenę 5,0. Podczas przechowywania wynik utrzymał się na tym samym poziomie. Najgorzej pod względem smaku oceniono mleko D i H, na ocenę 4. Należy zauważyć, że w ostatnim dniu przechowywania zanotowano nieznaczny spadek tej oceny, tj. do 3,6, co może świadczyć o pojawiających się zmianach fizykochemicznych w ocenianych próbkach mleka. Pozostałe próbki mleka były stabilne pod względem smaku, nie odnotowano bowiem obniżenia ich walorów smakowych podczas przechowywania. Zdaniem Sumińskiej i Dmytrów [2015], zachowanie odpowiednich warunków chłodniczych $\left(4-6^{\circ} \mathrm{C}\right)$ podczas przechowywania daje możliwość zachowania smaku mleka na odpowiednim poziomie. Wyższa temperatura przechowywania może natomiast prowadzić do obniżenia jego walorów smakowych, co zdaniem Autorek jest spowodowane zmianami zachodzącymi w składzie nienasyconych kwasów tłuszczowych. Wykazano, iż mleko podczas przechowywania charakteryzowało się stabilnością pod względem smaku słodkiego i mlecznego. W 10. dniu przechowywania stwierdzono zmiany w ocenie smaku gotowania, oceny obniżyły się nawet do 0 , co oznacza, że smak ten przestał być wyczuwalny przez degustatorów. W przypadku mleka D, H i I w ostatnim dniu przechowywania wyczuwalne były smaki obce, co może świadczyć o pojawieniu się początkowych stadiów niekorzystnych zmian enzymatycznych. Cais-Sokolińska i Danków [2003] również zauważyli, iż w trakcie przechowywania w warunkach chłodniczych mleka UHT dochodzi do zanikania smaku gotowanego, co jest wynikiem utleniania się grup - SH, przez rozpuszczony $\mathrm{w}$ mleku tlen, które są uwalniane podczas denaturacji białek serwatkowych, w szczególności $\beta$-laktoglobuliny

Zapach mleka został oceniony najniżej w porównaniu z pozostałymi wyróżnikami. Najwyższą oceną $(5,0)$ wyróżniało się jedynie mleko oznaczone literą C. Większość prób oceniono na ocenę dobrą $(4,0)$, natomiast najniżej $(3,0)$ próbki mleka D i H. Należy zaznaczyć, że we wszystkich próbach mleka, z wyjątkiem D, 
nie stwierdzono zmian zapachu podczas przechowywania. Zapach mleczny był wyczuwalny na stałym poziomie podczas całego okresu przechowywania. W przypadku mleka D i H degustatorzy w 10. dniu przechowywania wyczuli zapach obcy „lekko kwaśny”. Zauważono również podczas przechowywania zanikanie zapachu gotowania, co również było widoczne w przypadku smaku. Zapach gotowania utrzymywała się na stałym poziomie przez wszystkie dni przechowywania jedynie w mleku F. Wroński i Rzemieniewski [2009] w swoich badaniach potwierdzili również, że podczas dłuższego przechowywania mleka UHT dochodzi do powstawania zapachu nieświeżego, co może być wynikiem zachodzących reakcji lipolitycznych, oksydacyjnych, i proteolitycznych. Stwierdzili, że do bezpośrednich przyczyn powstawania tego zapachu zaliczamy koncentrację aldehydów, 2-pentanonu, acetonu oraz 2-heptagonu. Praktyczny brak wystąpienia wad zapachu mleka podczas przechowywania w warunkach chłodniczych $\left(4-6^{\circ} \mathrm{C}\right)$ może wynikać $\mathrm{z}$ faktu, iż każde mleko zapakowane było w opakowania kartonowe wielowarstwowe, które charakteryzują się dużą barierowością dla tlenu i światła, a tym samym zapobiegają powstawaniu niekorzystnych reakcji, które mogą się przyczynić do powstawania wad smaku czy zapachu.

W badaniach Szpakowskiej i Tymoszuk [2011] walory smakowe, zapachowe i konsystencja mleka UHT utrzymywały się na dobrym i bardzo dobrym poziomie w ciągu 8 dni po codziennym otwieraniu opakowania. Do podobnych wniosków doszli Brodziak i in. [2017b]. Wykazali, iż chłodnicze warunki przechowywania gwarantują utrzymanie w atrakcyjności sensorycznej otwartego mleka UHT przez co najmniej 7 dni.

\section{Podsumowanie}

Wykazano, iż mleko UHT po otwarciu podczas dziesięciodniowego okresu przechowywania w warunkach chłodniczych zachowywało swoje charakterystyczne cechy organoleptyczne, tj. barwę, konsystencję, smak i zapach i co ważne cechy te były akceptowalne przez degustatorów. Należy zaznaczyć, iż niższe oceny uzyskały próbki mleka marek własnych sieci handlowych. Pod koniec okresu przechowywania w mleku dochodziło do zanikania smaku i zapachu gotowania, pojawiały się $\mathrm{w}$ zamian obce smaki i zapachy. Zaobserwowane zmiany w jakości otwartego mleka UHT przechowywanego w warunkach chłodniczych wskazują zatem, iż produkt zachowuje swoje walory sensoryczne dłużej niż jest to deklarowane na opakowaniu, tj. 48 godzin.

\section{Bibliografia}

Baryłko-Pikielna N., Matuszewska I., 2014. Sensoryczne badania żywności. Podstawy - Metody Zastosowania. Wyd. Nauk. PTTŻ Kraków, 267-275. 
Brodziak A., Król J., Litwińczuk Z., Nowakowicz-Dębek B., Czernecki T., 2017a. Wpływ zachowania łańcucha chłodniczego na wartość odżywczą mleka spożywczego, w tym zawartość składników bioaktywnych. Przem. Chemiczny 96, 6, 1378-1380.

Brodziak A., Król J., Litwińczuk Z., Zaborska A., Czernecki T., 2017b. Effect of storage time under home refrigeration conditions on the quality of opened drinking milk. Mljekarstvo 67, 4, 283-296.

Cais-Sokolińska D., Pikul J., 2003. Charakterystyka barwy mleka sterylizowanego UHT przechowywanego w różnych warunkach temperaturowych. Chłodnictwo: organ Naczelnej Organizacji Technicznej 38(10), 32-35.

Cais-Sokolińska D., Danków R., Pikul J., 2002. Wpływ warunków temperaturowych przechowywania na zmiany fizyko-chemiczne i sensoryczne mleka UHT. Chłodnictwo: organ Naczelnej Organizacji Technicznej, 37(10), 40-43.

Dec B., 2011. Mleko o przedłużonej trwałości ESL synonimem wysokiego standardu higieny produkcji. Przegl. Mleczarski 6, 10-14.

IERiGŻ-PIB, 2019. Rynek mleka - stan i perspektywy. Analizy rynkowe - kwiecień 2019. Instytut Ekonomiki Rolnictwa i Gospodarki Żywnościowej - PIB, Warszawa.

Jakubczyk E., Bogdańska-Zaręba H., 2009. Jakość mleka spożywczego. Przegl. Mleczarski 6, 8-12.

Muszalska E., 2006. Rodzaje obróbki mleka w odniesieniu do ustawodawstwa oraz niektóre aspekty znakowania przetworów mlecznych. Przegl. Mleczarski 11, 68-70.

Pluta A., 2013. Czynniki warunkujące jakość i trwałość mleka spożywczego. Przegl. Mleczarski $339-400$.

Popov-Raljić J.V., Lakić N.S., Laličić-Petronijević J.G., Barać, M.B., Sikimić V.M., 2008. Color changes of uht milk during storage. Sensors 8, 5961-5974.

Rozporządzenie Komisji (WE) nr 1662/2006 z dnia 6 listopada 2006 r. zmieniające rozporządzenie (WE) nr 853/2004 Parlamentu Europejskiego i Rady ustanawiające szczególne przepisy dotyczące higieny w odniesieniu do żywności pochodzenia zwierzęcego (Dz. U. L 320/1).

Sałacki K., 2011. Mleko spożywcze. Przegl. Mleczarski 6, 50-52.

Sumińska P, Dmytrów I., 2015. Opakowania do produktów mlecznych. Przem. Spożywczy, 10, $38-42$.

Szpakowska M., Tymoszuk E., 2011. Badanie świeżości mleka UHT przechowywanego w warunkach chłodniczych po codziennym, otwieraniu opakowania. Zesz. Nauk. UE w Poznaniu, 196, $162-169$.

Śmietana Z., Krajewska-Kamińska E., Bohdziewicz K., Nalepa B., 2007. Porównanie jakości mikrobiologicznej mleka pasteryzowanego, mikrofiltrowanego, UHT. Żywność. Nauka. Technologia. Jakość, 2(51), 29-39.

Usarek A., Węgrzynowski T., Switka J., 1997. Zmiany jakości mleka sterylizowanego UHT w czasie przechowywania. Przegl. Mleczarski, 4, 104-108.

Walstra P., Wouters J.T.M., Geurts T.J., 2006. The impact of selected strains of probiotic bacteria on metabolite formation in set yoghurt. Dairy Science and Technology, CRC Press, Boca Raton, FL, USA, 497-512.

Wroński M., Rzemieniewski A., 2009. Wpływ długotrwałego przechowywania oraz sezonu produkcji na profil kwasów tłuszczowych w mleku konsumpcyjnym UHT. Przegl. Mleczarski 5, $12-16$.

Ziajka S. (red), 2008. Mleczarstwo, t. I, wyd. 2 popr. i uzup. Wyd. UWM Olsztyn.

Ziarno M., Czapska M., 2008. Skład jakościowy mikroflory mleka krowiego surowego i pasteryzowanego. Przegl. Mleczarski, 5, 4-8. 
Aleksandra Krochmal ${ }^{1}$, Joanna Jędrusyna ${ }^{1}$, Patrycja Dopieralska ${ }^{2}$, Magdalena Stobiecka², Anna Teter ${ }^{2}$, Monika Kędzierska-Matysek ${ }^{2}$

\section{Jakość serów twarogowych o zróżnicowanej zawartości tłuszczu}

Quality of tvarog cheeses with different fat content

Produkcja i spożycie mleka oraz produktów mlecznych w Polsce stale wzrasta. Według danych opublikowanych przez Główny Urząd Statystyczny w 2018 r. spożycie mleka i jego przetworów wyniosło 225 litrów na osobę. Najczęściej wybieranymi przez konsumentów produktami są mleko oraz sery, natomiast wyraźnie rzadziej spożywanymi przetworami są jogurty i napoje fermentowane, masło oraz śmietana.

Mleko i jego przetwory ze względu na wysoką wartość odżywczą są cennym składnikiem diety człowieka. Obecnie konsumenci w głównej mierze poszukują produktów oddziaływających korzystnie na ich zdrowie, co charakteryzuje produkty mleczne [Borowy i Kubiak 2012, Brodziak i in. 2017].

Jednym z najstarszych wyrobów mleczarskich jest twaróg, który charakteryzuje się dość niską wartością energetyczną, wysokim poziomem pełnowartościowego i dobrze przyswajalnego białka oraz wapnia. Posiada on wyjątkowe walory odżywcze, które sprawiają, że jest cennym składnikiem w codziennej diecie [Siemianowski i Szpendowski 2014].

Sery twarogowe na rynku krajowym obejmują liczną grupę produktów. Tradycyjne sery twarogowe, produkowane od wielu lat niezmiennie tą samą metodą, mogą uzyskać wyróżnienie znakiem „Jakość Tradycja”. System ten został opracowany przez Polską Izbę Produktu Regionalnego i Lokalnego oraz Związek Województw Rzeczpospolitej Polskiej. Powstał on w celu wyróżniania artykułów spożywczych wysokiej jakości, w szczególności produktów tradycyjnych. Do produkcji żywności oznaczanej tym symbolem muszą być używane wyłącznie surowce naturalne, wywodzące się z ekologicznych upraw lub gospodarstw stosujących Dobrą Praktykę Hodowlaną i Dobrą Praktykę Rolniczą, niezawierających części składowych GMO. Produkty muszą cechować się tradycyjną metodą wytwarzania i składem, wyjątkową jakością wynikającą z ich tradycyjnego pochodzenia lub reputacją wyróżniającą je od wyrobów zaliczanych do tej samej kategorii [Haska i Martyniuk 2019].

\footnotetext{
${ }^{1}$ SKN Nauk o Zwierzętach i Biogospodarki, Sekcja Towaroznawstwa i Bezpieczeństwa Żywności, Wydział Nauk o Zwierzętach i Biogospodarki, Uniwersytet Przyrodniczy w Lublinie

${ }^{2}$ Instytut Oceny Jakości i Przetwórstwa Produktów Zwierzęcych, Wydział Nauk o Zwierzętach i Biogospodarki, Uniwersytet Przyrodniczy w Lublinie, e-mail: anna.wolanciuk@up.lublin.pl
} 


\section{Charakterystyka serów twarogowych}

Twaróg jest jednym z podstawowych produktów wytwarzanych z mleka. Jest to też jeden z najprostszych składowo produktów, a zarazem najstarszy i najczęściej spożywany. Twarogi są tanie, ogólnie dostępne na rynku i bardzo popularne. Wysokie spożycie tego wyrobu podyktowane jest przyzwyczajeniami żywieniowymi, głęboko zakorzenioną tradycją naszego kraju, a także względami ekonomicznymi [Tońska i Klepacka 2017].

Według Rozporządzenia Parlamentu Europejskiego i Rady (UE) Nr 1308/2013 ser stanowi zastrzeżony termin przetworu mlecznego, natomiast przetwór mleczny jest to wyrób uzyskany od początku do końca z mleka, z przyzwoleniem dodatku substancji niezbędnych do jego wytworzenia, pod warunkiem, że nie są one stosowane $\mathrm{w}$ celu zastąpienia naturalnych składników mleka [Rozporządzenie Parlamentu Europejskiego i Rady (UE) Nr 1308/2013, Żarnecka 2016].

Zgodnie z definicją FAO/WHO, sery twarogowe są to świeże sery o konsystencji stałej lub półstałej, w których wzajemna zależność białek serwatkowych do kazeiny nie przewyższa ich zawartości w mleku, powstałych w skutek koagulacji: mleka, mleka odtłuszczonego i częściowo odtłuszczonego, maślanki, śmietanki lub śmietanki serwatkowej. Pojęcie „twaróg” określa masę kazeinową, która została skoagulowana metodą kwasową i odizolowana od serwatki do zawartości wody w stopniu 65-75\% [Ziarno i Zaręba 2017].

Twaróg, zwany również potocznie serem białym, jest serem niedojrzewającym uzyskanym w wyniku procesu zakwaszenia mleka. Jest on zaliczany do serów świeżych o białym zabarwieniu, kremowej lub grudkowatej konsystencji zależnej od poziomu zawartości tłuszczu w mleku. Według powszechnej charakterystyki twarogi cechują się łagodnym, lekko kwaśnym, czystym smakiem oraz zapachem. Mają jednolity kolor począwszy od białego (w przypadku twarogów chudych) do lekko kremowego (sery thuste), jednolite w pełnej masie. Cechą charakterystyczną dobrego twarogu jest średni poziom odcisku oraz gładkość w przekroju.

W sprzedaży dostępna jest szeroka gama rodzajów twarogów. Dzieli się je głównie ze względu na zawartość tłuszczu:

- śmietankowe - $14,5 \%$ thuszczu,

- thuste - ok. $6,5 \%$ thuszczu,

- półtluste - ok. 3-4\% thuszczu,

- chude - poniżej 3\% thuszczu.

Ze względu na technologię produkcji występują w formie serów twarogowych kwasowych i kwasowo-podpuszczkowych, przy czym wyraźnie różnią się one składem chemicznym [Bohdziewicz 2009].

Twarogi cechują się krótką trwałością i niezależnie od rodzaju opakowania nie należy przerywać łańcucha chłodniczego i przechowywać je w warunkach chłodniczych podczas transportu. Twarogi posiadają bardzo szerokie zastosowanie gastronomiczne. Najczęściej są spożywane w postaci naturalnej z delikatnymi dodatkami smakowymi, np. śmietaną, ziołami czy rzodkiewką. Twaróg jest 
również bardzo popularnym składnikiem dań obiadowych takich jak pierogi czy naleśniki, ale także jest wykorzystywany jako podstawa ciast, deserów i drożdżówek [Bohdziewicz 2014, Górska 2018].

\section{Wartość odżyweza}

Twaróg charakteryzuje się relatywnie niską wartością energetyczną oraz wysoką zawartością cennych składników odżywczych. Zawartość wody w serach twarogowych stanowi ok. 75\%, natomiast przeważającym składnikiem suchej masy jest białko [Siemianowski i Szpendowski 2015, Górska 2018].

Pod względem odżywczym twaróg jest produktem bogatym w łatwostrawne i pełnowartościowe białko. Dostarcza niezbędnych aminokwasów egzogennych koniecznych do kształtowania tkanek oraz do produkcji enzymów, ciał odpornościowych i hormonów. Zawartość białek w składzie suchej masy sera chudego wynosi ok. $80 \%$, półtłustego ok. $67 \%$, thustego ok. 53\%. Wszystkie białka mleka zostały zaliczone do białek pełnowartościowych. Oznacza to, że zawierają one niezbędne aminokwasy egzogenne oraz cechują się wysokim stopniem przyswajalności [Bohdziewicz 2010, Borowy i Kubiak 2012].

Mleko jest jedynym źródłem laktozy, a twaróg zawiera tylko jej śladowe ilości. Jest to podstawowy węglowodan, którego obecność w przewodzie pokarmowym wspomaga przyswajalność wapnia, magnezu i fosforu. Stanowi źródło energii dla prawidłowej pracy serca, wątroby i nerek oraz wspomaga funkcjonowanie komórek nerwowych [Borowy i Kubiak 2012, Ciołkowska 2015].

Sery twarogowe w zestawieniu z produktami pochodzenia roślinnego i wyrobami mięsnymi są źródłem lepiej przyswajalnego magnezu, wapnia i fosforu [Kunachowicz i in. 2017, Kaczkan i in. 2018].

Magnez bierze udział w wielu przemianach metabolicznych. Większość tego pierwiastka magazynowana jest w kościach, mięśniach, sercu, nerkach i płynach ustrojowych. Magnez normuje rytm serca, wpływa na przebieg metabolizmu potasu, witaminy $\mathrm{C}$ i wapnia, reguluje poziom cholesterolu, ma wpływ na kurczliwość mięśni i poziom pobudliwości układu nerwowego. Jego przyswajalność utrudnia obecność m.in. błonnika, tłuszczów nasyconych czy kwasu fitynowego, natomiast zwiększa dieta urozmaicona o białko zwierzęce, laktozę i tłuszcze nienasycone.

Wapń to niezbędny pierwiastek do wielu procesów życiowych odbywających się w organizmie. Warunkuje właściwe działanie układu kostnego, w którym zmagazynowane jest go ok. 99\%, ma wpływa na prawidłową krzepliwość krwi, właściwe funkcjonowanie mięśnia sercowego, a także na przewodnictwo tkanki nerwowej. Niedobór wapnia powoduje osteoporozę i łamliwość kości, zaburzenia rytmu serca, skurcze mięśni, jak również odpowiada za krzywicę i niedostateczny wzrost u dzieci [Tońska i Klepacka 2017].

Twarogi dostarczają w diecie witamin A, D, E, a także witaminy z grupy B. Witamina A bezpośrednio oddziałuje na rogówkę oka, nabłonek, regenerację 
skóry, błony śluzowe układu pokarmowego i oddechowego. Wspiera pracę układu odpornościowego i zwiększa aktywność białych krwinek.

Witamina D nadzoruje gospodarkę wapniowo-fosforową w organizmie, podtrzymuje homeostazę wapnia oraz wspomaga prawidłową pracę przytarczyc i funkcjonowanie nerek.

Witamina E przeciwdziała dolegliwościom ze strony układu krążenia, bierze udział w procesie krzepnięcia krwi oraz chroni witaminę A i nienasycone kwasy tłuszczowe przed utlenianiem [Ambroziak 2015, Ziajka 2008].

\section{Proces technologiczny wytwarzania serów twarogowych}

Cechą łączącą sery twarogowe jest to, że są otrzymywane poprzez właściwą obróbkę kazeiny, skoagulowanej metodą kwasową bądź kwasowo-podpuszczkową. Do grupy serów twarogowych kwasowych zalicza się klinki i krajankę, z kolei do kwasowo-podpuszczkowych serki niehomogenizowane i homogenizowane, ziarniste, wytwarzane z różnymi dodatkami smakowo-zapachowymi. Produkty te $\mathrm{w}$ większości przeznaczone są do spożycia bezpośredniego. Schemat produkcyjny dla serów twarogowych przedstawia rycinie 1 .

Mleko po normalizacji zawartości tłuszczu, pasteryzacji i schłodzeniu wzbogaca się o zakwas. Ilość zastosowanego zakwasu oraz temperatura koagulacji są zależne od metody stosowanej w procesie produkcji. Przy metodzie długotrwałej mleko zostaje schładzane do $21-23^{\circ} \mathrm{C}$, a koagulacja trwa od 14 do 16 godzin. Dodatek zakwasu wynosi wówczas $1-1,5 \%$. W metodzie krótkotrwałej, gdzie z kolei schładza się mleko do temperatury $35^{\circ} \mathrm{C}$, czas koagulacji to $6-8$ godzin, a dodatek zakwasu wynosi $5 \%$. Jednakże z powodu niewystarczającego rozwoju bakterii aromatyzujących produkt otrzymany tą metodą cechuje się małą aromatycznością.

Czas krojenia skrzepu decyduje o dalszych właściwościach ziarna, dlatego musi być właściwie dobrany. Rozpoczyna się ono, gdy skrzep osiągnie średnią zwięzłość oraz pH w przedziale od 4,7 do 4,8 (22-23을 rozdrobniony równomiernie, dzięki czemu ziarno osusza się jednakowo. Rozmiar ziarna powinien wynosić od 0,8 do $1,5 \mathrm{~cm}$. Następnie gęstwę pozostawia się na ok. 30 minut, w tym czasie przebiega synereza ziarna.

Ziarno twarogowe zostaje ogrzewane do $56-64^{\circ} \mathrm{C}$. Temperatura powinna wtedy wzrastać o $1^{\circ} \mathrm{C}$ w ciągu 5 minut. Ziarno jest mieszane w celu uzyskania równomiernej synerezy i zapobiegnięcia wytworzenia tzw. skórzastości ziarna, która osłabia przebieg wydzielania serwatki. Gęstwa pozostaje utrzymana w temperaturze 20-30 minut i następuje dosuszenie ziarna.

Po osuszeniu ziarna serwatka zostaje oddzielona, a ziarno jest trzykrotnie płukane zimną wodą. Ziarna serowe poddaje się płukaniu w celu schłodzenia skutkującego utrwaleniem otrzymanej tekstury, wypłukaniem laktozy, stłumieniem procesów fermentacyjnych [Gołąbek 2011, Siemianowski i in. 2011]. 


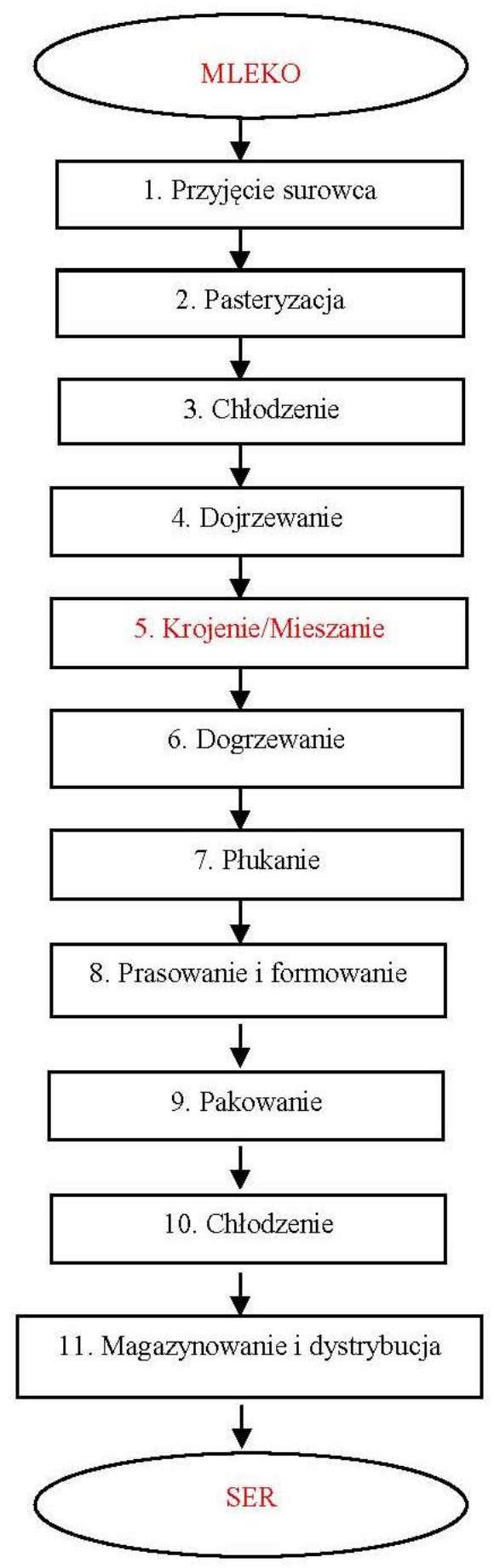

Ryc. 1. Schemat produkcji twarogu [oprac. na podst. Gołąbek 2011, Siemianowski i in. 2011] 


\section{Wady twarogów}

Podczas produkcji serów twarogowych mogą występować różnego rodzaju nieprawidłowości, które w końcowym efekcie przyczyniają się do powstawania wad w gotowym produkcie. Wady twarogów dotyczące smaku, zapachu, konsy-

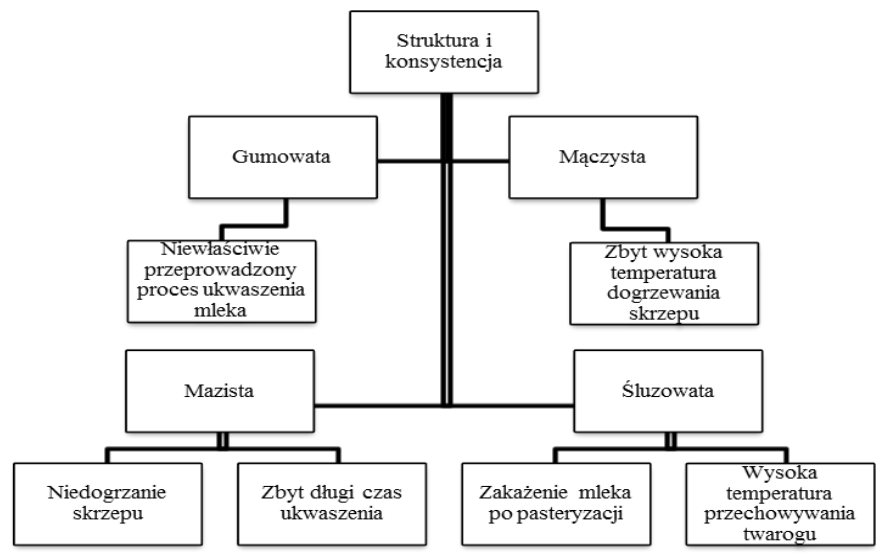

Ryc. 2. Wady struktury i konsystencji serów twarogowych

Źródło: Opracowanie własne na podst. Ziajka [2008], Litwińczuk i in. [2011]

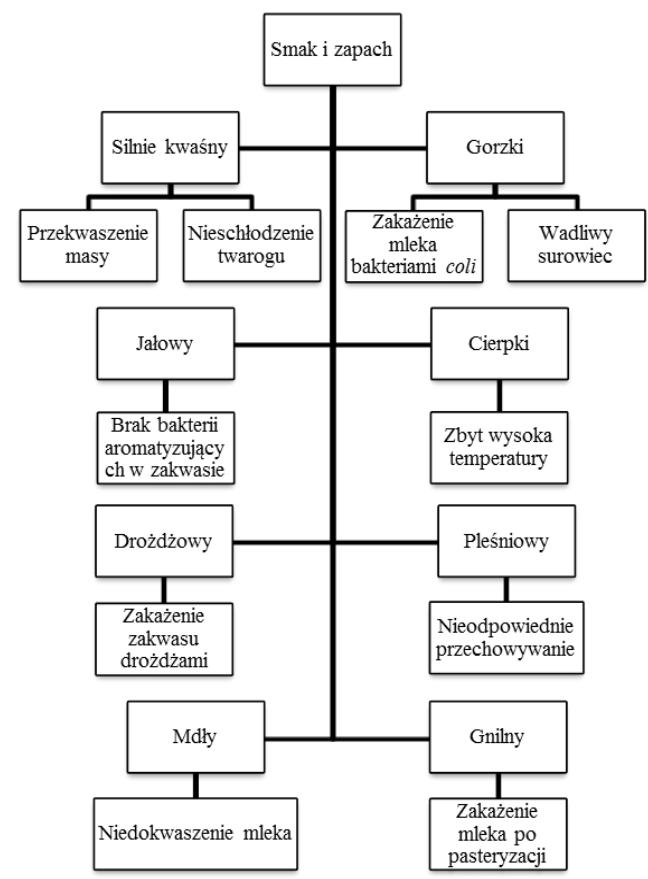

Ryc. 3. Wady smaku i zapachu serów twarogowych Źródło: Opracowanie własne na podst. Ziajka [2008], Litwińczuk i in. [2011] 
stencji oraz barwy mogą wynikać z użycia niskiej jakości surowca do produkcji lub zastosowania nieodpowiednich parametrów w trakcie procesu technologicznego [Marszałkowska-Jakubik 2011].

Zbyt kwaśny smak twarogu jest efektem np. działania zbyt wysokiej temperatury $\mathrm{w}$ trakcie pasteryzacji mleka. Mdły smak jest natomiast konsekwencją niewystarczającego zakwaszenia mleka, w wyniku czego ser ulega zepsuciu. Niekiedy twarogi przybierają grudkowatą formę, co jest skutkiem zbyt silnego ścięcia się białka. Taka struktura twarogu może być rozciągliwa, elastyczna i nie pozwala się rozdrobnić na klarowną masę. Natomiast nadmiernie maziste stężenie sera może wynikać z niewystarczającego ogrzania skrzepu, przekwaszenia mleka lub zarażenia sera drożdżakami [Górska 2018].

$\mathrm{Z}$ błędów podczas procesu produkcji twarogu może wynikać wiele wad związanych z cechami sensorycznymi serów, które w ostateczności obniżają jakość produktu. Potencjalne wady oraz przyczyny ich powstania przedstawione zostały na rycinach 2 i 3 .

\section{Wymagania jakościowe dla twarogów}

Wyróżniki jakościowe w przypadku serów twarogowych są określane w Polskiej Normie PN-A-86300:1991 Mleko i przetwory mleczarskie. Sery niedojrzewające (tab. 1). Monitorowane są parametry fizykochemiczne, a w szczególności zawartość suchej masy oraz tłuszczu. Równie ważna jest kwasowość produktów oraz bezpieczeństwo mikrobiologiczne.

Tabela 1. Wymagania dla serów twarogowych [PN-A-86300:1991]

\begin{tabular}{|l|c|c|c|c|}
\hline \multirow{2}{*}{ Cechy } & \multicolumn{4}{c|}{ Sery twarogowe kwasowe } \\
\cline { 2 - 5 } & \multicolumn{1}{|c|}{ pełnotłuste } & thuste & półtłuste & chude \\
\hline Smak i zapach & czysty, łagodny, lekko kwaśny, posmak pasteryzacji \\
\hline Struktura i konsystencja & \multicolumn{2}{|c|}{$\begin{array}{l}\text { jednolita, zwarta, bez grudek, lekko luźna, dopuszcza się } \\
\text { lekko ziarnistą dla twarogów chudych }\end{array}$} \\
\hline Barwa & biała do lekko kremowej, jednolita w całej masie \\
\hline $\begin{array}{l}\text { Zawartość wody \%, } \\
\text { nie więcej niż }\end{array}$ & 70 & 70 & 73 & klinki 72 \\
\hline $\begin{array}{l}\text { Zawartość tłuszczu w suchej } \\
\text { masie \%, nie więcej niż }\end{array}$ & $42 \pm 3$ & $30 \pm 2$ & $15 \pm 2$ & - \\
\hline Kwasowość ${ }^{\circ}$ SH, nie wyższa niż & 80 & 90 & 100 & 110 \\
\hline Pasteryzacja & \multicolumn{4}{|c|}{ skuteczna } \\
\hline Bakterie z grupy coli & \multicolumn{5}{|c|}{ nieobecne w $0,001 \mathrm{~g}$} \\
\hline
\end{tabular}

Celem badań była ocena barwy i tekstury serów twarogowych o zróżnicowanej zawartości tłuszczu. 


\section{Właściwości fizyczne serów twarogowych}

Oznaczono parametry barwy oraz tekstury serów twarogowych chudych, półtłustych i tłustych wytworzonych pod marką trzech różnych producentów: SM Bieluch, SM Mlekovita (Delikate) oraz OSM Bychawa. Łącznie oceniono 27 serów (po 3 chude, półtłuste i tłuste od każdego z producentów). Charakterystykę materiału badawczego przedstawiono w tabeli 2 . Instrumentalny pomiar barwy wykonano za pomocą chromatometru Minolta CR-310 (Minolta Camera Co. Ltd., Osaka, Japonia). Wyniki pomiaru barwy zostały przedstawione jako jednostki trójchromatyczne w układzie L*, a*, b*. Pomiary zostały przeprowadzone w trzykrotnym powtórzeniu. Za pomocą jednokolumnowej maszyny wytrzymałościowej Zwick/RoellProLine Z0.5. oznaczono następujące parametry tekstury: twardość, siła spójności, sprężystość, gumowatość, żuwalność i przylegalność Oznaczenia zostały wykonane $\mathrm{w}$ trzech powtórzeniach. Uzyskane wyniki poddano analizie statystycznej w programie StatSoft Inc. STATISTICA ver. 6. Istotność różnic między średnimi wartościami określono testem NIR Fishera $(\mathrm{p}<0,05)$.

Tabela 2. Charakterystyka produktów użytych w badaniu

\begin{tabular}{|c|c|c|}
\hline Produkt, masa & Składniki & Wartość odżywcza w 100 g produktu \\
\hline $\begin{array}{l}\text { Ser twarogowy chudy } \\
\text { Bieluch, } 250 \mathrm{~g}\end{array}$ & $\begin{array}{l}\text { mleko pasteryzowane } \\
\text { bakterie fermentacji } \\
\text { mlekowej }\end{array}$ & $\begin{array}{l}\text { - wartość energetyczna } 366 \mathrm{~kJ} / 86 \mathrm{kcal} \\
\text { - tłuszcz } 0,0 \mathrm{~g} ; \mathrm{w} \text { tym } \mathrm{kwasy} \text { tłuszczowe } \\
\text { nasycone } 0,0 \mathrm{~g} \\
\text { - węglowodany } 3,5 \mathrm{~g} \text {; w tym cukry } 3,5 \mathrm{~g} \\
\text { - białko } 18,0 \mathrm{~g} \\
\text { - sól } 0,10 \mathrm{~g}\end{array}$ \\
\hline $\begin{array}{l}\text { Ser twarogowy pół- } \\
\text { tłusty Bieluch, } 250 \mathrm{~g}\end{array}$ & $\begin{array}{l}\text { mleko pasteryzowane } \\
\text { bakterie fermentacji } \\
\text { mlekowej }\end{array}$ & $\begin{array}{l}\text { - wartość energetyczna } 474 \mathrm{~kJ} / 113 \mathrm{kcal} \\
\text { - tłuszcz } 4,0 \mathrm{~g} ; \mathrm{w} \text { tym kwasy thuszczowe } \\
\text { nasycone } 2,6 \mathrm{~g} \\
\text { - węglowodany } 3,8 \mathrm{~g} ; \mathrm{w} \text { tym cukry } 3,8 \mathrm{~g} \\
\text { - białko } 15,5 \mathrm{~g} \\
\text { - sól } 0,10 \mathrm{~g}\end{array}$ \\
\hline $\begin{array}{l}\text { Ser twarogowy tłusty } \\
\text { Bieluch, } 250 \mathrm{~g}\end{array}$ & $\begin{array}{l}\text { mleko pasteryzowane } \\
\text { bakterie fermentacji } \\
\text { mlekowej }\end{array}$ & $\begin{array}{l}\text { - wartość energetyczna } 606 \mathrm{~kJ} / 145 \mathrm{kcal} \\
\text { - thuszcz } 8,0 \mathrm{~g} ; \mathrm{w} \text { tym kwasy tłuszczowe } \\
\text { nasycone } 5,1 \mathrm{~g} \\
\text { - węglowodany } 3,7 \mathrm{~g} ; \mathrm{w} \text { tym cukry } 3,7 \mathrm{~g} \\
\text { - białko } 14,5 \mathrm{~g} \\
\text { - sól } 0,10 \mathrm{~g}\end{array}$ \\
\hline $\begin{array}{l}\text { Ser twarogowy chudy } \\
\text { Delikate, } 250 \mathrm{~g}\end{array}$ & $\begin{array}{l}\text { mleko } \\
\text { kultury bakterii } \\
\text { mlekowych }\end{array}$ & $\begin{array}{l}\text { - wartość energetyczna } 407 \mathrm{~kJ} / 96 \mathrm{kcal} \\
\text { - tłuszcz } 0,2 \mathrm{~g} ; \mathrm{w} \text { tym kwasy thuszczowe } \\
\text { nasycone } 0,1 \mathrm{~g} \\
\text { - węglowodany } 3,5 \mathrm{~g} \text {; w tym cukry } 3,5 \mathrm{~g} \\
\text { - białko } 20 \mathrm{~g} \\
\text { - sól } 0,05 \mathrm{~g}\end{array}$ \\
\hline
\end{tabular}




\begin{tabular}{|c|c|c|}
\hline $\begin{array}{l}\text { Ser twarogowy pół- } \\
\text { tłusty Delikate, } 250 \mathrm{~g}\end{array}$ & $\begin{array}{l}\text { mleko } \\
\text { kultury bakterii } \\
\text { mlekowych }\end{array}$ & $\begin{array}{l}\text { - wartość energetyczna } 505 \mathrm{~kJ} / 120 \mathrm{kcal} \\
\text { - tłuszcz } 4,0 \mathrm{~g} \text {; w tym kwasy thuszczowe } \\
\text { nasycone } 2,6 \mathrm{~g} \\
\text { - węglowodany } 4,0 \mathrm{~g} \text {; w tym cukry } 4,0 \mathrm{~g} \\
\text { - białko } 17 \mathrm{~g} \\
\text { - sól } 0,05 \mathrm{~g}\end{array}$ \\
\hline $\begin{array}{l}\text { Ser twarogowy thusty } \\
\text { Delikate, } 250 \mathrm{~g}\end{array}$ & $\begin{array}{l}\text { mleko, } \\
\text { kultury bakterii } \\
\text { mlekowych }\end{array}$ & $\begin{array}{l}\text { - wartość energetyczna } 628 \mathrm{~kJ} / 150 \mathrm{kcal} \\
\text { - tłuszcz } 8,0 \mathrm{~g} \text {; w tym kwasy thuszczowe } \\
\text { nasycone } 5,0 \mathrm{~g} \\
\text { - węglowodany } 3,5 \mathrm{~g} \text {; w tym cukry } 3,5 \mathrm{~g} \\
\text { - białko } 16,0 \mathrm{~g} \\
\text { - sól } 0,10 \mathrm{~g}\end{array}$ \\
\hline $\begin{array}{l}\text { Ser twarogowy chudy } \\
\text { Bychawa } 250 \mathrm{~g}\end{array}$ & $\begin{array}{l}\text { mleko odtłuszczone } \\
\text { kultury bakterii } \\
\text { fermentacji mlekowej }\end{array}$ & $\begin{array}{l}\text { - wartość energetyczna } 440 \mathrm{~kJ} / 104 \mathrm{kcal} \\
\text { - thuszcz } 0,5 \mathrm{~g} \text {; w tym kwasy thuszczowe } \\
\text { nasycone } 0,2 \mathrm{~g} \\
\text { - węglowodany } 6,1 \mathrm{~g} \text {; w tym cukry } 3,8 \mathrm{~g} \\
\text { - białko } 19,0 \mathrm{~g} \\
\text { - sól } 0,08 \mathrm{~g}\end{array}$ \\
\hline $\begin{array}{l}\text { Ser twarogowy pół- } \\
\text { tłusty Bychawa, } 250 \mathrm{~g}\end{array}$ & $\begin{array}{l}\text { mleko odtłuszczone } \\
\text { kultury bakterii } \\
\text { fermentacji mlekowej }\end{array}$ & $\begin{array}{l}\text { - wartość energetyczna } 514 \mathrm{~kJ} / 122 \mathrm{kcal} \\
\text { - tłuszcz } 4,0 \mathrm{~g} \text {; w tym kwasy thuszczowe } \\
\text { nasycone } 3,3 \mathrm{~g} \\
\text { - węglowodany } 3,9 \mathrm{~g} \text {; w tym cukry } 2,0 \mathrm{~g} \\
\text { - białko } 17,6 \mathrm{~g} \\
\text { - sól } 0,04 \mathrm{~g}\end{array}$ \\
\hline $\begin{array}{l}\text { Ser twarogowy thusty } \\
\text { Bychawa, } 330 \mathrm{~g}\end{array}$ & $\begin{array}{l}\text { mleko odttuszczone, } \\
\text { kultury bakterii } \\
\text { fermentacji mlekowej }\end{array}$ & $\begin{array}{l}\text { - wartość energetyczna } 602 / 144 \text { kcal } \\
\text { - tłuszcz } 9,0 \mathrm{~g} ; \mathrm{w} \text { tym kwasy thuszczowe } \\
\text { nasycone } 5,4 \mathrm{~g} \\
\text { - węglowodany } 3,1 \mathrm{~g} \text {; w tym cukry } 1,4 \\
\text { - białko } 16,0 \mathrm{~g} \\
\text { - sól } 0,04 \mathrm{~g}\end{array}$ \\
\hline
\end{tabular}

Skład produktów zestawiono na podstawie deklaracji producentów na etykietach

\section{Barwa twarogów}

Jasność serów twarogowych była wyrównana, mieściła się w zakresie 91,32-92,01 (tab. 3). Wykazano statystycznie istotne różnice w udziale barwy zielonej i żółtej w serach w zależności od poziomu tłuszczu w produkcie. W przypadku udziału barwy zielonej (-a*) wartości były zróżnicowane i zawierały się między $-0,35$ a $-1,35$. Wykazano, że wraz ze wzrostem zawartości thuszczu w serze

Tabela 3. Wyniki pomiaru barwy $(\bar{x} \pm \mathrm{SD})$

\begin{tabular}{|l|l|c|c|c|}
\hline \multicolumn{2}{|c|}{ Parametr/Producent } & L* & $\mathrm{a}^{*}$ & $\mathrm{~b}^{*}$ \\
\hline \multirow{4}{*}{$\begin{array}{l}\text { Sery twarogowe } \\
\text { chude }\end{array}$} & Bieluch & $91,96 \pm 0,17$ & $-1,19^{\mathrm{B}} \pm 0,10$ & $9,07 \pm 0,39$ \\
& Delikate & $91,79 \pm 0,17$ & $-1,35^{\mathrm{A}} \pm 0,12$ & $9,47 \pm 0,19$ \\
& Bychawa & $91,99 \pm 0,26$ & $-1,09^{\mathrm{B}} \pm 0,13$ & $9,38 \pm 0,27$ \\
& Średnia & $\mathbf{9 1 , 9 1} \pm \mathbf{0 , 2 0}$ & $\mathbf{- 1 , 2 1 ^ { \mathbf { Z } } \pm \mathbf { 0 , 1 6 }}$ & $\mathbf{9 , 3 1} \mathbf{X}^{\mathbf{X}} \pm \mathbf{0 , 3 2}$ \\
\hline
\end{tabular}




\begin{tabular}{|l|l|l|l|l|}
\hline & Bieluch & $91,77 \pm 0,20$ & $-0,99^{\mathrm{A}} \pm 0,11$ & $9,86 \pm 0,21$ \\
Sery twarogowe & Delikate & $91,77 \pm 0,09$ & $-0,85^{\mathrm{B}} \pm 0,09$ & $9,91 \pm 0,28$ \\
półtluste & Bychawa & $91,69 \pm 0,22$ & $-0,94^{\mathrm{A}} \pm 0,10$ & $10,27 \pm 0,48$ \\
& Średnia & $\mathbf{9 1 , 7 4} \pm \mathbf{0 , 1 5}$ & $-\mathbf{0 , 9 3}^{\mathrm{Y}} \pm \mathbf{0 , 1 1}$ & $\mathbf{1 0 , 0 1} \pm \mathbf{Y}, \mathbf{0 , 3 5}$ \\
\hline & Bieluch & $91,62 \pm 0,41$ & $-0,57^{\mathrm{A}} \pm 0,09$ & $10,65^{\mathrm{B}} \pm 0,71$ \\
\multirow{3}{*}{ Sery twarogowe thuste } & Delikate & $91,32 \pm 0,23$ & $-0,35^{\mathrm{B}} \pm 0,07$ & $9,90^{\mathrm{A}} \pm 0,14$ \\
& Bychawa & $92,01 \pm 0,31$ & $-0,49^{\mathrm{A}} \pm 0,10$ & $9,88^{\mathrm{A}} \pm 0,25$ \\
& Średnia & $\mathbf{9 1 , 6 5} \pm \mathbf{0 , 4 1}$ & $\mathbf{- 0 , 4 7}^{\mathbf{X}} \pm \mathbf{0 , 1 1}$ & $\mathbf{1 0 , 1 4} \mathbf{Y}^{\mathrm{Y}} \pm \mathbf{0 , 5 4}$ \\
\hline
\end{tabular}

$\mathrm{A}, \mathrm{B}-$ różnice $\mathrm{w}$ obrębie grupy produktów istotne przy $\mathrm{p}<0,05 ; \mathrm{X}, \mathrm{Y}, \mathrm{Z}$ - różnice między grupami produktów istotne przy $\mathrm{p}<0,05$

istotnie $(\mathrm{p}<0,05)$ zmniejszał się udział barwy zielonej $\left(-\mathrm{a}^{*}\right)$, a wzrastał udział barwy żółtej $\left(b^{*}, p<0,05\right)$. Udziały barwy zielonej i żółtej były zróżnicowane także w obrębie poszczególnych grup serów.

\section{Parametry tekstury ocenianych serów}

Istotnym aspektem w ocenie fizykochemicznej twarogów są parametry tekstury. Wykazano istotne różnice w teksturze ocenianych serów zarówno między grupami, jak i w ich obrębie. Sery twarogowe półtłuste charakteryzowały się istotnie najniższymi $(\mathrm{p}<0,05)$ wartościami wszystkich ocenianych parametrów. Sery o najniższej zawartości tłuszczu wykazywały najwyższą twardość $(2,42 \mathrm{~N}$; $\mathrm{p}<0,05)$, sprężystość $(1,29 ; \mathrm{p}<0,05)$ i żuwalność $(1,03 \mathrm{~N} ; \mathrm{p}<0,05)$. Gumowatość serów chudych i tłustych była zbliżona (odpowiednio $0,88 \mathrm{~N}$ i $0,89 \mathrm{~N}$ ). Produkty o najwyższej zawartości tłuszczu cechowały się największą siłą spójności $(0,53 \mathrm{~mJ})$ i przylegalnością $(1,95 \mathrm{~N})$. Warto zauważyć, że wśród każdej ocenianej grupy serów (niezależnie od poziomu tłuszczu) produkty pochodzące z mleczarni bychawskiej wyróżniały się istotnie wyższą twardością, siłą spójności, gumowatością, żuwalnością i przylegalnością. Należy podkreślić, że jako jedyne w ocenianej stawce były one wytworzone na bazie mleka odtłuszczonego, co mogło wpłynąć na cechy tekstury produktu finalnego.

Sery twarogowe są cennym składnikiem codziennej diety wielu konsumentów. Są źródłem pełnowartościowego białka, lekkostrawnego tłuszczu, witamin z grupy B oraz składników mineralnych. Ocena barwy serów o zróżnicowanej zawartości thuszczu wykazała, że wraz ze wzrostem zawartości thuszczu w serze istotnie $(\mathrm{p}<0,05)$ zmniejszał się udział barwy zielonej $\left(\mathrm{a}^{*}\right)$, a wzrastał udział barwy żółtej $\left(\mathrm{b}^{*}, \mathrm{p}<0,05\right)$.

Wykazano również istotne różnice w teksturze ocenianych serów. Najwyższą twardość, sprężystość i żuwalność wykazywały sery chude, a siłę spójności i przylegalność - twarogi tłuste. Z kolei sery twarogowe półtłuste charakteryzowały się istotnie najniższymi wartościami wszystkich ocenianych parametrów. 
Tabela 4. Parametry tekstury ocenianych serów $(\bar{x} \pm \mathrm{SD})$

\begin{tabular}{|c|c|c|c|c|c|c|c|}
\hline \multicolumn{2}{|c|}{ Parametr/Producent } & \multirow{2}{*}{$\begin{array}{c}\begin{array}{c}\text { Twardość } \\
(\mathrm{N})\end{array} \\
1,92^{\mathrm{B}} \pm 0,11\end{array}$} & \multirow{2}{*}{$\begin{array}{c}\begin{array}{c}\text { Siła spójno- } \\
\text { ści (mJ) }\end{array} \\
0,27^{\mathrm{A}} \pm 0,01\end{array}$} & \multirow{2}{*}{$\begin{array}{l}\text { Sprężystość } \\
2,03 \pm 0,08\end{array}$} & \multirow{2}{*}{$\begin{array}{c}\begin{array}{c}\text { Gumowatość } \\
(\mathrm{N})\end{array} \\
0,57 \pm 0,07\end{array}$} & \multirow{2}{*}{$\begin{array}{c}\begin{array}{c}\text { Żuwalność } \\
(\mathrm{N})\end{array} \\
1,16 \pm 0,16\end{array}$} & \multirow{2}{*}{$\begin{array}{c}\begin{array}{c}\text { Przylegalnoś } \\
(\mathrm{N})\end{array} \\
1,05 \pm 0,09\end{array}$} \\
\hline \multirow{4}{*}{$\begin{array}{l}\text { Sery twarogowe } \\
\text { chude }\end{array}$} & Bieluch & & & & & & \\
\hline & Delikate & $1,39^{\mathrm{A}} \pm 0,18$ & $0,27^{\mathrm{A}} \pm 0,02$ & $0,90 \pm 0,02$ & $0,51 \pm 0,10$ & $0,46 \pm 0,09$ & $0,98 \pm 0,11$ \\
\hline & Bychawa & $3,93^{\mathrm{C}} \pm 0,44$ & $0,94^{\mathrm{B}} \pm 0,15$ & $0,95 \pm 0,06$ & $1,56 \pm 0,17$ & $1,48 \pm 0,24$ & $3,41 \pm 0,82$ \\
\hline & Średnia & $2,42^{\mathrm{Y}} \pm 1,19$ & $0,50^{\mathrm{Y}} \pm \mathbf{0 , 3 4}$ & $1,29^{Z} \pm 0,56$ & $\mathbf{0 , 8 8} 8^{\mathrm{Y}} \pm \mathbf{0 , 5 2}$ & $1, \mathbf{0 3}^{\mathrm{Z}} \pm \mathbf{0 , 4 8}$ & $1,81^{\mathrm{Y}} \pm 1,27$ \\
\hline \multirow{4}{*}{$\begin{array}{l}\text { Sery twarogowe } \\
\text { półtluste }\end{array}$} & Bieluch & $1,86^{\mathrm{A}} \pm 0,21$ & $0,32^{\mathrm{A}} \pm 0,11$ & $0,94 \pm 0,07$ & $0,63 \pm 0,06$ & $0,59^{\mathrm{A}} \pm 0,07$ & $1,11 \pm 0,17$ \\
\hline & Delikate & $1,54^{\mathrm{A}} \pm 0,18$ & $0,36^{\mathrm{A}} \pm 0,10$ & $0,91 \pm 0,09$ & $0,60 \pm 0,02$ & $0,55^{\mathrm{A}} \pm 0,01$ & $1,52 \pm 0,11$ \\
\hline & Bychawa & $2,68^{\mathrm{B}} \pm 0,39$ & $0,60^{\mathrm{B}} \pm 0,13$ & $0,94 \pm 0,09$ & $0,87 \pm 0,12$ & $0,83^{\mathrm{B}} \pm 0,17$ & $1,59 \pm 0,24$ \\
\hline & Średnia & $2,03^{x} \pm 0,55$ & $0,43^{x} \pm 0,14$ & $\mathbf{0 , 9 3}{ }^{\mathrm{X}} \pm \mathbf{0 , 0 8}$ & $0,72^{X} \pm 0,15$ & $0,65^{x} \pm 0,16$ & $1,41^{x} \pm 0,28$ \\
\hline \multirow{4}{*}{$\begin{array}{l}\text { Sery twarogowe } \\
\text { thuste }\end{array}$} & Bieluch & $1,70^{\mathrm{AB}} \pm 0,26$ & $0,39^{\mathrm{A}} \pm 0,15$ & $1,19^{\mathrm{B}} \pm 0,09$ & $0,58^{\mathrm{A}} \pm 0,18$ & $0,70^{\mathrm{B}} \pm 0,20$ & $1,50^{\mathrm{B}} \pm 0,70$ \\
\hline & Delikate & $1,34^{\mathrm{A}} \pm 0,17$ & $0,28^{\mathrm{A}} \pm 0,08$ & $0,91^{\mathrm{A}} \pm 0,14$ & $0,44^{\mathrm{A}} \pm 0,08$ & $0,41^{\mathrm{A}} \pm 0,09$ & $0,91^{\mathrm{A}} \pm 0,16$ \\
\hline & Bychawa & $3,89^{\mathrm{B}} \pm 0,44$ & $0,91^{\mathrm{B}} \pm 0,04$ & $0,95^{\mathrm{A}} \pm 0,10$ & $1,63^{\mathrm{B}} \pm 0,13$ & $1,55^{\mathrm{C}} \pm 0,16$ & $3,44^{\mathrm{B}} \pm 0,28$ \\
\hline & Średnia & $2,31^{\mathrm{Y}} \pm 1,22$ & $\mathbf{0 , 5 3}{ }^{\mathrm{Y}} \pm \mathbf{0 , 3 0}$ & $1,02^{\mathrm{Y}} \pm 0,14$ & $\mathbf{0 , 8 9 ^ { \mathrm { Y } }} \pm \mathbf{0 , 5 7}$ & $\mathbf{0 , 8 8} 8^{\mathrm{Y}} \pm \mathbf{0 , 5 3}$ & $1,95^{\mathrm{Y}} \pm 1,21$ \\
\hline
\end{tabular}

$\mathrm{A}, \mathrm{B}$ - różnice w obrębie grupy produktów istotne przy $\mathrm{p}<0,05 ; \mathrm{X}, \mathrm{Y}, \mathrm{Z}$ - różnice między grupami produktów istotne przy $\mathrm{p}<0,05$ 


\section{Bibliografia}

Ambroziak A., 2015. Tłuszcz mlekowy - źródło witamin A, D 3 , E, K. Przegl. Mleczarski 2, 18-22.

Borowy T., Kubiak S., 2012. Walory odżywcze mleka i przetworów mlecznych. Przegl. Mleczarski 9, 14-16.

Bohdziewicz K., 2009. Twaróg - pierwszy ser świata. Przegl. Mleczarski 2, 4-9.

Bohdziewicz K., 2010. Wpływ transglutaminazy na proces produkcji, wydatek oraz jakość twarogów. Przegl. Mleczarski 2, 4-9.

Bohdziewicz K., 2014. Dopuszczalna tolerancja deklarowanej zawartości tłuszczu i nazewnictwo serów twarogowych. Przegl. Mleczarski 6, 50-52.

Brodziak A., Król J., Barłowska J., 2017. Mleko i produkty mleczne źródłem składników biologicznie czynnych. Przem. Spożywczy 10, 8-13.

Ciołkowska A., 2015. Laktoza i jej pochodzenie. Przegl. Mleczarski 3, 32-36.

Gołąbek J., 2011. Produkcja sera twarogowego klinki metodą tradycyjną z uwzględnieniem nowych udoskonaleń technologii i pakowania. Przegląd Mleczarski 11, 22-23.

Górska J., 2018. Twarogi tradycyjne. Tradycja w twarogach. Forum Mleczarskie Handel 6.

GUS, 2018. Rocznik Statystyczny Rzeczpospolitej Polskiej, Warszawa.

Haska A., Martyniuk E., 2019. Wybrane metody wyróżniania produktów spożywczych na rynku., Żywność. Nauka. Technologia. Jakość 26, 18-31.

Kaczkan M., Bienias A., Małgorzewicz S., 2018. Realizacja założeń diety niskofosforanowej a ukryte źródła fosforu. Forum Nefrol., 11(1), 15-23.

Kunachowicz H., Przygoda B., Nadolna I., Iwanow K., 2017. Tabele składu i wartości odżywczej żywności. PZWL, Warszawa.

Litwińczuk Z., Litwińczuk A., Barłowska J., Florek M., Król J., Grodzicki T., Kędzierska-Matysek M., Skałecki P., 2011. Metody oceny towaroznawczej surowców i produktów zwierzęcych. Wyd. UP w Lublinie, Lublin.

Marszałkowska-Jakubik J., 2011. Twarogi. Przegl. Mleczarski 11, 20-21.

PN-A-86300:1991 Mleko i przetwory mleczarskie. Sery niedojrzewające.

Rozporządzenie Parlamentu Europejskiego i Rady (UE) Nr 1308/2013 z dnia 17 grudnia 2013 r. ustanawiające wspólną organizację rynków produktów rolnych.

Siemianowski K., Szpendowski J., 2015. Metody włączania białek serwatkowych w technologii niedojrzewających kwasowych serów twarogowych., Żywność. Nauka. Technologia. Jakość 5(102), 23-32.

Siemianowski K., Szpendowski J., 2014. Znaczenie twarogu w żywieniu człowieka. Probl. Higieny i Epidem., 95(1), 115-119.

Siemianowski K., Szpendowski J., Bohdziewicz K., 2011. Postęp w produkcji twarogów kwasowych. Przegl. Mleczarski, 11, 4-12.

Tońska E., Klepacka J., 2017. Sery twarogowe jako źródło wybranych makroelementów - Mg, Ca, P. Przegl. Mleczarski 3, 18-21.

Ziajka S., 2008. Mleczarstwo. Zagadnienia wybrane T. 1., WUWM, Olsztyn.

Ziarno M., Zaręba D., 2017. Twarogi. Poznaj dobry twaróg. Forum Mleczarskie Handel 4.

Żarnecka E., 2016. Nazewnictwo serów w praktyce. Przegl.Mleczarski10, 10-15. 
Łukasz Kozian ${ }^{1,4}$, Paulina Kochanek ${ }^{1}$, Jakub Kalinowski ${ }^{1}$, Monika Szymczuk ${ }^{1}$, Damian Zarajczyk $^{1}$, Marian Flis ${ }^{2}$, Kinga Kropiwiec-Domańska ${ }^{3}$, Marek Babicz ${ }^{3}$

\section{Wpływ upraw rolnych na biologię dzików}

The influence of agricultural crops on the biology of wild boars

Dzik (Sus scrofa L.) należy do rzędu parzystokopytnych, rodziny świniowatych. Zwierzęta te najchętniej bytują w kompleksach lasów mieszanych, gdzie występują tereny podmokłe $\mathrm{z}$ udziałem bagien i mokradeł. Zasiedlają również inne typy siedlisk o małej lesistości. Jeszcze w drugiej połowie XX w. duże kompleksy leśne były bardziej preferowanym miejscem bytowania gatunku Sus scrofa w porównaniu $\mathrm{z}$ terenami polnymi, które charakteryzują się małym udziałem drzew i krzewów. Obecnie obserwuje się odwrotne tendencje [Przybylski 2015].

Dzik jest zwierzęciem ciągle poszukującym nowej bazy żerowej. Wielkoobszarowe uprawy zbóż, w tym kukurydzy, spowodowały, że dzik z typowo leśnego zwierzęcia stał się gatunkiem coraz częściej bytującym na polach uprawnych. Czynnikami zachęcającymi dziki do migracji z kompleksów leśnych na pola uprawne jest duża atrakcyjność bazy żerowej oraz możliwość stałego tam przebywania od wiosny do jesieni. Zwierzęta te bytują w lesie podczas największych spadków temperatury, natomiast wraz ze wzrostem temperatury wracają na obszary, w których przebywały $\mathrm{w}$ okresie wiosenno-jesiennym [Pałubicki i in. 2011]. Pola uprawne mogą stanowić miejsce przebywania dzików od momentu, gdy np. zboża, rzepak osiągną odpowiednią wysokość pozwalającą zapewnić im dostateczne schronienie. W praktyce rolniczej okres ten przypada na połowę maja i trwa aż do czasu zbioru płodów rolnych, w przypadku kukurydzy nawet do końca listopada. Zmiany w strukturze upraw przyczyniają się do zmiany składu pożywienia dzików. Do roślin uprawnych, atrakcyjnych dla dzików można zaliczyć: kukurydzę, rzepak, grykę, proso oraz ziemniaki [Przybylski 2015].

Dziki wykazują szereg specyficznych cech związanych z rozrodem [Flis i in. 2018, Flis 2019a]. Dojrzałość rozpłodową samice dzika osiągają w wieku 7-22 miesięcy. Tak duża różnica wynika z konieczności osiągnięcia przez samicę

\footnotetext{
${ }^{1}$ Studenckie Koło Naukowe Nauk o Zwierzętach i Bioekonomii Sekcja Hodowli i Biotechnologii Świń, Uniwersytet Przyrodniczy w Lublinie

2 Katedra Etologii Zwierząt i Łowiectwa, Zakład Gospodarki Łowieckiej, Wydział Nauk o Zwierzętach i Biogospodarki, Uniwersytet Przyrodniczy w Lublinie

${ }^{3}$ Instytut Hodowli Zwierząt i Ochrony Bioróżnorodności, Zakład Hodowli i Biotechnologii Świń, Wydział Nauk o Zwierzętach i Biogospodarki, Uniwersytet Przyrodniczy w Lublinie

4 e-mail: lukaszkozian169@gmail.com
} 
minimalnej masy ciała na poziomie $30 \mathrm{~kg}$. Ciąża według różnych źródeł trwa od 112 do 140 dni [Mauget 1982, Fruziński 1993]. Na czas jej trwania wpływa między innymi wiek samicy. U młodszych samic ciąża trwa krócej, natomiast u starszych dłużej. Średnio samice rodzą od 2 do 8 prosiąt w roku. Jakkolwiek obecnie odnotowuje się mioty liczące nawet kilkanaście osobników, co świadczy o kierunkowych zmianach, jakie zachodzą w rozrodzie dzików. Na wielkość miotu wpływają takie czynniki jak wiek oraz masa ciała samic [Fernández-Llario i Mateos-Quesada 1998]. Samice dzików rozpoczynają sezon rozrodczy od wejścia w okres rui, tzw. huczki, który przypada na czas skracania długości dnia świetlnego [Weiler i in. 1996]. Szczyt sezonu rozrodczego przypada w listopadzie oraz grudniu [Kozdrowski i Dubiel 2004].

Potencjał rozrodczy samic oraz śmiertelność osobników wpływa na strukturę wieku i wielkość populacji dzików. Liczebność tego gatunku w okresie ostatnich kilkunastu lat wykazywała znaczące wahania. W roku 2010 odnotowano 249,9 tys. szt., w 2015 - 264,8 tys. szt., natomiast w latach 2018 i 2019 odpowiednio 87,9 tys. szt. i 71,8 tys. szt. [Rocznik Statystyczny Rolnictwa 2019].

Dziki nie mają na większości terenu naszego kraju naturalnych wrogów, którzy mogliby zredukować ich liczbę oraz rozrost populacji. Obecnie wysokie upadki wśród dzików notuje się między innymi z powodu afrykańskiego pomoru świń (ASF) [Pejsak i in. 2014, Flis 2019b]. ASF to choroba wirusowa dzików i trzody chlewnej. Jest zakaźną, zaraźliwą i stosunkowo szybko szerzącą się chorobą, z towarzyszącym jej dużym wskaźnikiem śmiertelności. Czynnikiem patogennym jest wirus afrykańskiego pomoru świń (ASFV), przedstawiciel rodziny Asfaviridae rodzaju Asfivirus. Zakażenie może nastąpić przez bezpośredni kontakt, drogą pokarmową, przez uszkodzoną skórę lub przez kontakt pośredni z materiałem (np. słomą, zbożem), który miał styczność z chorymi zwierzętami. Zarażenie drogą kropelkową jest możliwe tylko w odległości kilku metrów [Markowska-Daniel i Pejsak 2014]. W Polsce pierwsze przypadki ASF zanotowano w 2014 r. [Pejsak i in. 2014]. Od tego czasu choroba sukcesywnie rozprzestrzenia się na terenie naszego kraju, a najbardziej dotknięte są nią wschodnie obszary Polski. Czynnościami prawnie usankcjonowanymi, chroniącymi krajowe pogłowie świń przeciw ASF, są między innymi: zapobieganie rozprzestrzenianiu się choroby oraz jej szybkie zwalczanie [Dz. U. 2015 poz. 517, Dz. U. 2015 poz. 754, Flis 2019c].

Celem opracowania było omówienie oddziaływania upraw zbożowych w Polsce, ze szczególnym uwzględnieniem kukurydzy, na wybrane elementy biologii dzików.

Przeprowadzono autorską ankietę dotyczącą bytowania dzików w środowisku rolniczym i jego wpływu na elementy związane z procesami życiowymi tego gatunku zwierząt dzikich. W badaniu uczestniczyło 100 producentów i hodowców trzody chlewnej, którzy prowadzą swoją działalność na terenie województwa lubelskiego. 
Problematyka dotycząca dzików nie jest obca mieszkańcom rejonów wiejskich, $\mathrm{z}$ rozwinięta produkcją trzody chlewnej. $\mathrm{W}$ tym aspekcie należy podkreślić, że hodowcy i producenci świń zwracają szczególną uwagę na stan populacji dzików, co jest spowodowane szybko rozprzestrzeniającym się afrykańskim pomorem świń. Jak wynika z przeprowadzonej ankiety, większość respondentów (88\%) uważa dzika za gatunek stanowiący zagrożenie dla hodowli i chowu trzody chlewnej. Należy tu podkreślić, że do przeniesienia wirusa do gospodarstwa bardzo często dochodzi poprzez słomę lub ziarno zboża, w którym bytowały zarażone dziki. Coraz częściej obserwuje się u dzików zmiany w behawiorze w wyniku, których zmniejsza się lęk tych zwierząt przed ludźmi. Powoduje to bytowanie dzików w bliskości siedzib ludzkich, co sprzyja szerzeniu się ASF, a w konsekwencji prowadzi do strat ekonomicznych nie tylko w produkcji żywca wieprzowego, ale również zbóż i pasz [Flis 2020].

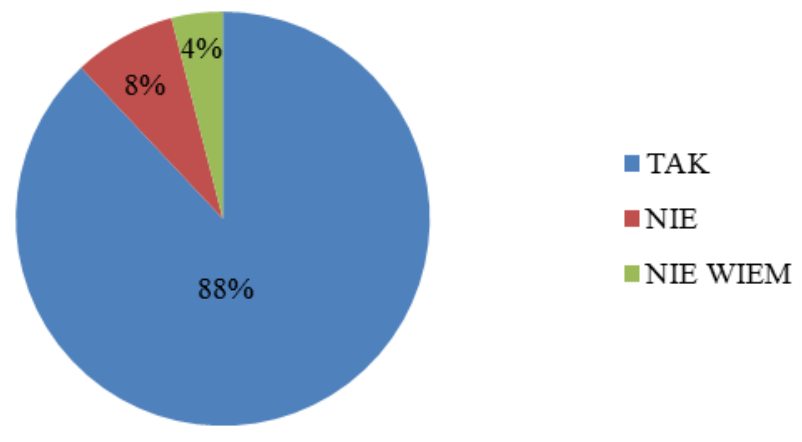

Ryc. 1. Czy według Pana/Pani dziki stanowią zagrożenie dla hodowli i produkcji świń w Polsce? Źródło: Opracowanie własne

W Polsce struktura upraw zbóż zmieniała się w kolejnych latach. Aktualnie w żywieniu świń preferowane są kolejno: jęczmień, pszenica, kukurydza, pszenżyto, żyto, owies, w tym nagoziarnisty. Jęczmień zaliczany jest do zbóż pastewnych. Szacuje się, że jego wykorzystanie w żywieniu zwierząt sięga $67-70 \%$ [Łopaciuk $i$ in. 2011]. Na skład chemiczny ziarna jęczmienia wpływa szereg czynników, do których można zaliczyć: formę jęczmienia (oplewiona lub nieoplewiona), glebę, klimat i nawożenie [Wirkijowska i in. 2016, Gąsiorowski i in. 1997]. Żyto zawiera wartościowe składniki żywieniowe, między innymi błonnik pokarmowy, witaminy czy polifenole. Zagrożeniem w uprawie żyta są przede wszystkim choroby grzybowe, które mogą obniżać wartość pokarmową ziarna [Dzienis 2018]. Duże znaczenie gospodarcze ma również pszenżyto. Charakteryzuje się stosunkowo wysoką zawartością białka w ziarnie i wyższą jego strawnością w porównaniu z żytem, mniejszymi wymaganiami glebowymi w porównaniu z pszenicą, odpornością na zakwaszenie gleby, suszę oraz choroby [Jaśkiewicz 2009]. Na prze- 
łomie ostatnich lat można zaobserwować zwiększoną liczbę upraw pszenżyta w Polsce, które jest dobrym składnikiem dawki pokarmowej dla tuczników. Najbardziej wartościowym zbożem pod względem udziału składników odżywczych jest pszenica. W większości w Polsce wysiewana jest na glebach lekkich, ale przy prawidłowo prowadzonej uprawie nie wpływa to ujemnie na uzyskiwane plony [Weber i Podolska 2008]. Natomiast plenność owsa zależy od tempa wzrostu oraz długości okresu wegetacji. Przyśpieszenie wzrostu prowadzi do wyższej plenności. W żywieniu zwierząt wykorzystuje się dwie odmiany: oplewiony i nagoziarnisty. W przeprowadzonych badaniach wykazano, że owies nagi wpływa korzystnie na rozród świń [Stasiak i in. 2013].

Szczególne znaczenie dla dzików ma kukurydza. Od drugiej połowy lat 70. XX w. można zaobserwować wzrastającą konkurencyjność uprawy kukurydzy (Zea mays L.) w stosunku do innych roślin zbożowych. Dotyczy to nie tylko terenów o najlepszych warunkach klimatycznych, ale również rejonów wyżynnych i województw północnych. Pod względem potencjału plonowania oraz tempa wzrostu plonów w produkcji kukurydza zdecydowanie dominuje wśród roślin zbożowych [Arseniuk i Olesiak 2017]. W bardzo sprzyjającym warunkach można uzyskać plon w granicach 15 t/ha ziarna lub 25 t/ha suchej masy całych roślin [Fugol i Szlachta 2010].

Jest to roślina o wielorakim zastosowaniu [Czarnocka i in. 2018], ze szczególnym uwzględnieniem żywienia trzody chlewnej i bydła [Cromwell i in. 2011, Grela i Skomiał 2015]. Obecnie jest również jednym z podstawowych składników diety dzików [Przybylski 2015]. Według Pałubickiego i Grajewskiego [2010], zwiększanie areału uprawy kukurydzy na ziarno oddziałuje na wzrost populacji dzików, ponieważ następuje wówczas powiększenie bazy żerowej oraz miejsc osłonowych $\mathrm{w}$ rozległych strukturach agrocenoz. Warto również podkreślić, że w wyniku prac hodowlanych w roślinach uprawnych wzrasta ilość białka i energii, a tym samym rzutuje to na kondycję osobniczą dzików [Zawadzki i in. 2011].

Liczba gospodarstw uprawiających kukurydzę w Polsce, jak również jej znaczenie gospodarcze wzrasta. Według danych [Rocznik Statystyczny RP 2006, Rocznik Statystyczny Rolnictwa 2011] całkowita powierzchnia uprawy kukurydzy na ziarno w latach 2005-2010 kształtowała się na poziomie 488-730 tys. ha. Natomiast wysoki wzrost powierzchni uprawy nastąpił w 2012 r. i osiągnął ponad milion hektarów. Tendencja ta utrzymuje się do dzisiaj [Rocznik Statystyczny Rolnictwa 2018]. Zbiór kukurydzy na ziarno odbywa się na przełomie października i listopada, co pozwala na stosunkowo długie korzystanie przez dziki $\mathrm{z}$ łatwo dostępnej bazy pokarmowej. Jednakże pojawiające się $\mathrm{w}$ tym okresie niesprzyjające warunki pogodowe, jak opady deszczu i duża wilgotność powietrza, mogą być przyczyną porażenia ziarna kukurydzy przez mikotoksyny [Nicpoń $\mathrm{i}$ in. 2016].

Mikotoksyny zaliczane są do drugorzędowych metabolitów, produkowanych przez liczne gatunki grzybów [Barabasz i Pikulicka 2017]. Ilość wytwarzanych mikotoksyn zależy od wilgotności, $\mathrm{pH}$, składu podłoża do wzrostu oraz tempera- 
tury inkubacji. Do mikotoksyn zalicza się: aflatoksyny, które produkowane są przez różne szczepy Aspergillus flavus i Aspergillus parasiticus, ochratoksyny produkowane przez niektóre gatunki Penicillium i Aspergillus, trichoteceny wytwarzane przez wiele gatunków grzybów niedoskonałych, takich jak Fusarium sp., Stachybotrys sp. i Myrothecium sp. [Grajewski 2006, Wróbel 2014]. Jedną z najpowszechniej występujących mikotoksyn w środowisku jest zearalenon (ZEA), wytwarzany przez grzyby z rodzaju Fusarium. Występowanie tego związku potwierdzono na całym świecie u takich gatunków zbóż, jak owies, żyto, pszenica, ryż, kukurydza czy sorgo. Obecność tej toksyny można powszechnie wykazać w paszach przeznaczonych do skarmiania zwierząt. Wysokie stężenia odnotowuje się w kiszonkach, co jest spowodowane wykorzystaniem pasz i zielonek zanieczyszczonych pleśniami i wytwarzanymi przez nie metabolitami [Gwiazdowska 2014]. Rozwój grzybów wytwarzających zearalenon ma miejsce w okresie późnej jesieni [Nicpoń $i$ in. 2016]. W tym czasie resztki pożniwne w uprawie kukurydzy stanowią doskonały żer dla dzików. Największe stężenie zearalenonu w żołądku zaobserwowano pomiędzy grudniem a lutym [Flis i Rataj 2017].

Przyjmując, że kukurydza i inne zboża stanowią składnik diety świń i dzików uważa się, iż w określonych warunkach wpływają one na rozród tych gatunków. Wynika to $\mathrm{z}$ faktu, że mogący pojawić się w zbożu zearalenon powoduje zmiany w rozrodzie, które zaburzają zapłodnienie, owulację, implantację zarodków oraz ich prawidłowy rozwój. Mechanizm oddziaływania zearalenonu polega na hamowaniu wytwarzania hormonu przysadkowego FSH, co powoduje opóźnianie rozwoju pęcherzyków jajnikowych. Następstwem tego są zaburzenia cyklu, co w rezultacie prowadzi do zaburzenia płodności [Jakimiuk i in. 2006, Fink-Gremmels 2008]. Jak podają Seelling i in. [2015], zawartość zearalenonu w paszy w ilościach $1-5 \mathrm{mg} \cdot \mathrm{kg}^{-1} / \mathrm{kg}$ jest przyczyną zmian w narządach rodnych macior, natomiast ilość $100 \mathrm{mg} \cdot \mathrm{kg}^{-1} / \mathrm{kg}$ powoduje całkowitą bezpłodność macior. U dzików obecność tej mikotoksyny może prowadzić zarówno do wydłużenia okresu rui, jak i występowania huczki dwa razy w ciągu roku. Zjawisko to nosi nazwę poliestryczności. Do tej pory występowało ono u dzików bardzo rzadko. Początkowe obserwacje pozwoliły stwierdzić, iż zmiany te mogą przyczyniać się zarówno do zmniejszenia, jak i zwiększenia liczby miotów. Ponadto mogą powodować przystępowanie do rozrodu samic, które są jeszcze zbyt młode i niedojrzałe płciowo [Pałubicki i Grajewski 2010]. Wymienione elementy mogą być przyczyną zmiany w liczebności populacji dzików [Flis i Rataj 2017]. Odmienne zdanie zaprezentowali w swojej pracy Nicpoń i in. [2016], którzy na podstawie badań morfologicznych i biochemicznych krwi dzików nie stwierdzili negatywnego wpływu mikotoksyn w kukurydzy na ich rozród.

Jak wynika z przeprowadzonej ankiety, 51\% respondentów uznało, że dostęp dzików do upraw zbożowych, w tym głównie kukurydzy, nie wpływa na zmiany w funkcjonowaniu ich organizmu. Jednocześnie $42 \%$ ankietowanych nie podzielała tego zdania, uważając otwarty dostęp dzików do upraw jako czynnik wpływający na ich biologię, a zwłaszcza rozród (ryc. 2). 


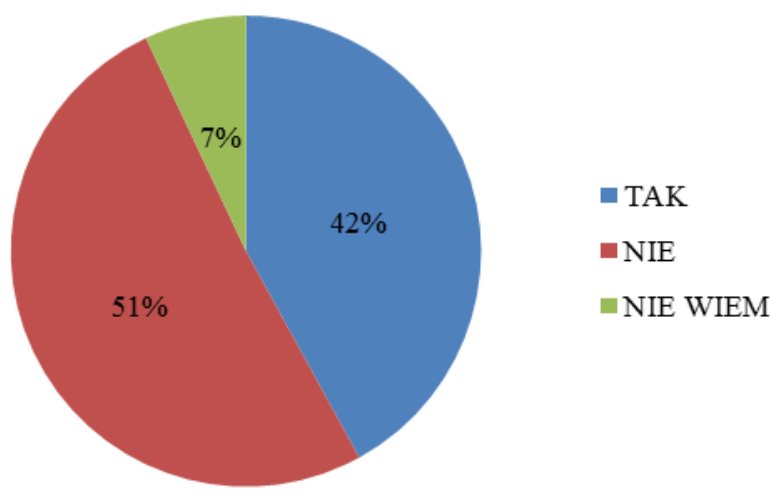

Ryc. 2. Czy według Pana/Pani zmiana bazy żerowej dzików z dostępem do upraw zbożowych może wpływać na ich biologię, w tym rozród?

Źródło: Opracowanie własne

Respondenci przedstawili również swoje zdanie w zakresie oddziaływania bazy żerowej dzików na ich biologię w odniesieniu do potencjalnych konsekwencji przejawiających się zmianami w budowie anatomicznej dzików (ryc. 3).

Spośród respondentów, którzy odpowiedzieli twierdząco na to pytanie (38\%) najwięcej osób (54\%) wskazało na możliwości pojawienia się zmian w budowie i funkcjonowaniu narządów wewnętrznych.

Jak wynika z badań własnych, wielkość narządów dzików jest porównywalna do świni domowej, nawet przy zróżnicowanej masie ciała obydwu gatunków. Przy czym zaobserwowano, że w obrębie gatunku świni domowej wyższa produkcyjność określonych ras wpływa na spadek masy narządów wewnętrznych. Przykładem tego jest rodzima rasa puławska i wysoko produkcyjna rasa polska biała zwisłoucha (pbz).

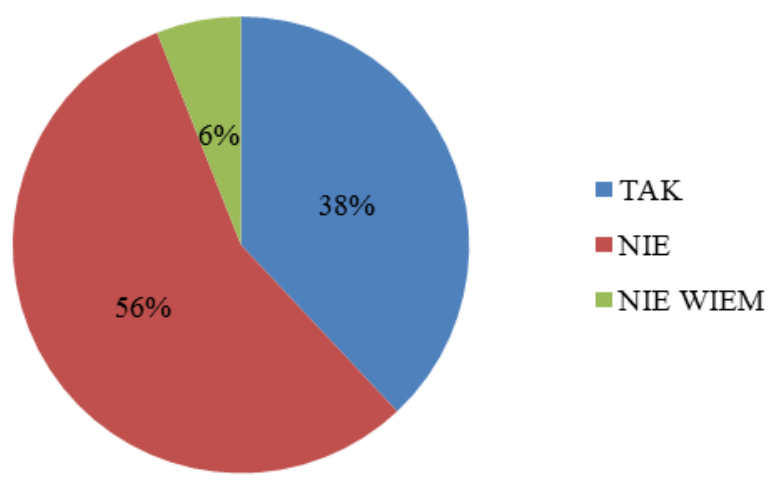

Ryc. 3. Czy według Pana/Pani zmiana bazy żerowej dzików może wpływać na ich biologię np. zmiany w budowie anatomicznej?

Źródło: Opracowanie własne 


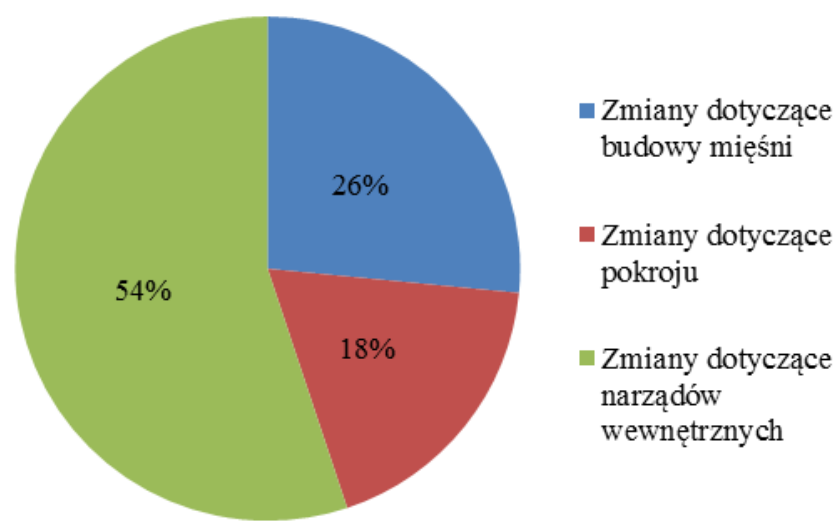

Ryc. 4. Jakie zmiany anatomiczne może powodować obecna dieta dzików? Źródło: Opracowanie własne

Tabela 1. Masa (g) wybranych narządów wewnętrznych dzika (średnia masa ciała $55 \mathrm{~kg}$ ) i ras świni domowej (średnia masa ciała $105 \mathrm{~kg}$ )

\begin{tabular}{|l|c|c|c|c|c|c|}
\hline \multirow{2}{*}{ Narządy } & \multicolumn{6}{|c|}{ Grupa } \\
\cline { 2 - 7 } & \multicolumn{2}{|c|}{ rasa pbz } & \multicolumn{2}{c|}{ rasa puławska } & \multicolumn{2}{c|}{ dzik } \\
\cline { 2 - 7 } & $\bar{x}$ & SD & $\bar{x}$ & SD & $\bar{x}$ & SD \\
\hline Język & 267 & 14,2 & 291 & 30,2 & 228 & 29,8 \\
Serce & 411 & 13,5 & 431 & 41,1 & 420 & 48,1 \\
Płuca & 790 & 22,0 & 892 & 28,9 & 871 & 31,5 \\
Wątroba & 1469 & 31,5 & 1684 & 31,8 & 1399 & 254,8 \\
Nerka & 169 & 19,8 & 187 & 20,1 & 250 & 47,2 \\
\hline
\end{tabular}

Źródło: badania własne

Podsumowując, można stwierdzić, że nastąpiły pewne zmiany w biologii dzika, mogące być skutkiem migracji z lasu na tereny uprawne oraz rozszerzenia bazy żerowej. Wzrost areału uprawy zbóż, szczególnie kukurydzy, wpłynął na zwiększenie bazy pokarmowej dzików i zmianę środowiska życia. Przyczynił się również do powstania zaburzeń fizjologicznych będących między innymi skutkiem pobierania pokarmu porażonego przez mikotoksyny, w wyniku czego obserwuje się zaburzenia $\mathrm{w}$ rozrodzie tego gatunku zwierząt. Jakkolwiek prowadzone badania $\mathrm{z}$ tego zakresu nie przynoszą jednoznacznej odpowiedzi [Nicpoń i in. 2016]. 


\section{Bibliografia}

Arseniuk E., Oleksiak T., 2017. Historia rozwoju i naukowego wsparcia hodowli, uprawy i produkcji kukurydzy w Polsce. Agro Serwis. 9, 12-13.

Barabasz W., Pikulicka A., 2017. Mykotoksyny - zagrożenie dla zdrowia ludzi i zwierząt. Część 1. Mykotoksyny - charakterystyka, występowanie, toksyczność dla organizmów. J. Health Stud. Med. 3, 65-108.

Cromwell G.L., Azain M.J., Adeola O., Baidoo S.K., Carter S.D., Crenshaw T.D., Kim W.S., Mahan D.C., Miller P.S., Shannon M.C., 2011. Corn distillers dried grains with solubles in diets for growing finishing pigs: A cooperative study. J. Anim. Sci. 89, 2801-2811, https://doi.org/10.2527/jas.2010-3704.

Czarnocka A., 2018. ABC uprawy kukurydzy na ziarno, Wyd. Hortpress, Warszawa.

Dz. U. 2015 poz. 517. Rozporządzenie Ministra Rolnictwa i Rozwoju Wsi z dnia 3 kwietnia 2015 r. w sprawie wprowadzenia „Programu bioasekuracji mającego na celu zapobieganie szerzeniu się afrykańskiego pomoru świń" na lata 2015-2018.

Dz. U. 2015 poz. 754. Rozporządzenie Ministra Rolnictwa i Rozwoju Wsi z dnia 6 maja 2015 r. w sprawie zwalczania afrykańskiego pomoru świń.

Dzienis G., 2018. Żyto ozime - gatunek niedoceniany w Polsce. Praca przeglądowa. Agronomy Sci. 73 (1), 19-28, https://doi.org/10.24326/asx.2018.1.2.

Fernández-Llario P., Mateos-Quesada P., 1998. Body size and reproductive parameters the wildboar Sus scrofa. Acta Theriol. 43, 139-444, https://doi.org/10.4098/AT.arch.98-54.

Fink-Gremmels J., 2008. The role of mycotoxins in the Heath and performance of dairy of dairycows. Vet. J. 176, 84-92, https://doi.org/0.1016/j.tvj1.2007.12.034.

Flis M., 2019a. Biologia, reprodukcja i demografia dzików w realiach wzmożonego odstrzału ze względu na występowanie wirusa afrykańskiego pomoru świń. Życie Weter. 94(2), 149-153.

Flis M., 2019b. Afrykański pomór świń - fakty, mity, rzeczywistość. Życie Weter. 94(3), 199-202.

Flis M., 2019c. Zwalczanie afrykańskiego pomoru świń na drodze administracyjnej. Życie Weter. 94(6), 419-422.

Flis M., 2020. Możliwości rozprzestrzeniania się afrykańskiego pomoru świń oraz jego występowanie w Polsce w 2019 r. Życie Weter. 95(2), 86-88.

Flis M., Grela E.R., Gugała D., Rataj B., 2018. Sezonowość rozrodu i charakterystyka masy tuszy dzików pozyskanych na Wyżynie Lubelskiej. Med. Weter. 74, 477-480, https://doi.org/10.21521/mw.6018.

Flis M., Rataj B., 2017. Zmiany w krajobrazie rolniczym a wskaźniki rozrodu dzików. Wiadomości Zoot., 55(4), 124-131.

Fruziński B., 1993. Dzik. Wyd. Anton, Warszawa.

Fugol M., Szlachta J., 2010. Przydatność substratów pochodzenia rolniczego i odpadów przemysłu rolno-spożywczego w świetle danych literaturowych. Inż. Roln. 6(124), 77-83.

Gąsiorowski H., 1997. Wartość technologiczna jęczmienia i niektóre metody jej oceny. W: H. Gąsiorowski (red.), Jęczmień - chemia i technologia; PWRiL, Poznań, 250-262.

Grajewski J., 2006. Mikotoksyny i grzyby pleśniowe zagrożeniem dla człowieka i zwierząt. Wyd. UKW Bydgoszcz, Bydgoszcz.

Grela E.R., Skomiał J., 2015. Zalecenia żywieniowe i wartość pokarmowa pasz dla świń. Normy żywienia świń. Wyd. Instytut Fizjologii i Żywienia Zwierząt PAN, Jabłonna.

Gwiazdowska D., 2014. Poprawa jakości i bezpieczeństwa zdrowotnego żywności i pasz poprzez mikrobiologiczną eliminację mikotoksyn fuzaryjnych. Wyd. UE w Poznaniu, Poznań.

Jakimiuk E., Kuciel-Lisiecka G., Zwierzchowski W., Gajęcka M., Obremski K., Zielonka Ł., Sikorska-Wyszyńska E., Gajęcki M., 2006. Zmiany morfometryczne układu rozrodczego loszek podczas mikotoksykozy zearalenonowej. Med. Weter. 62(1), 99-102.

Jaśkiewicz B., 2009. Czynniki decydujące o regionalnym zróżnicowaniu produkcji pszenżyta w Polsce. Fragm. Agron. 26 (2), 72-80.

Kozdrowski R., Dubiel A., 2004. Biologia rozrodu dzika. Med. Weter. 60, 1251-1253. 
Łopaciuk W., Drożdż J., Krzemiński M., Włodarczyk M., 2011. Rynek zbóż stan i perspektywy. Wyd. IERiGŻ-PIB, Warszawa.

Markowska-Daniel I., Pejsak Z., 2014, Afrykański pomór świń, Życie Weter. 3, 191-196,

Mauget R., 1982. Seasonality of reproduction in the wildboar. W: D.J.A. Cole, G.R. Foxcroft (red.), Control of Pig Reproduction. Butterworlhs, London, 509-526.

Nicpoń J., Sławuta P., Nicpoń J., 2016. Wpływ toksykozy zearalenonowej na wyniki badania morfologicznego i biochemicznego krwi dzików. Med. Weter. 72, 250-254.

Pałubicki J., Grajewski J., 2010. Wpływ zasiewów kukurydzy na wzmożoną rozrodczość dziczych populacji, a problem odszkodowań łowieckich, Zarządzanie ochroną przyrody $\mathrm{w}$ lasach 4 , 111-119.

Pałubicki J., Grajewski J., Łabudzki L., 2011. Wpływ struktury pozyskania dzików na wzrost populacji i wielkość szkód łowieckich model polski i niemiecki. Zarządzanie ochroną przyrody w lasach 5, 110-121.

Pejsak Z., Truszczyński M., Niemczuk K., Kozak E., Markowska-Daniel I., 2014. Epidemiology of African Swine Fever in Poland since the detection of the first case, Pol. J. Vet. Sci. 17(4), $665-672$.

Przybylski A., 2015. Dzik. Praktyczne zasady gospodarowania populacją. Wyd. Zachodni Poradnik Łowiecki, Piła.

Rocznik Statystyczny Leśnictwa, 2019. GUS, Warszawa.

Rocznik Statystyczny Rolnictwa, 2011. GUS, Warszawa.

Rocznik Statystyczny Rolnictwa, 2018. GUS, Warszawa.

Rocznik Statystyczny Rzeczypospolitej Polskiej, 2006. GUS, Warszawa.

Seeling K., Dänicke S., Ueberschär K.H., Lebzien P., Flachowsky G., 2015. On the effects of Fusariumtoxin-contaminated wheat and the feed intake level on the metabolism and carryover of zearalenone in dairy cows. Food Addit. Contamin. 22(9), 847-855.

Stasiak A., Kamyk-Kamieński P., Babicz M., Kasprzyk A., Lechowski J., 2013. Płodność i behawior płciowy loszek mieszańców rasy puławskiej i wielkiej białej polskiej żywionych mieszankami z udziałem owsa nagoziarnistego. Przegl. Hodowlany 3, 19-21.

Weber R.; Podolska G., 2008. Wpływ sposobu uprawy roli, terminu i gęstości siewu na plonowanie odmian pszenicy ozimej. Inż. Roln. 1(99), 395-400.

Weiler U., Claus R , Dehnhard M., Hofäcker S., 1996. Influence of the photoperiod and a light reverse program on metabolically active hormones and food intake in domestic pigs compared with a wild boar. Can. J. Anim. Sci. 76(53), 1-539, https://doi.org/10.4141/cjas96-080.

Wirkijowska A., Rzedzicki Z., Sobota A., Sykut-Domańska E., Zarzycki P., Bartoszek K., Kuzawińska E., 2016. Jęczmień w żywieniu człowieka. Pol. J. Agron. 25, 41-51.

Wróbel B., 2014, Zagrożenia zwierząt i ludzi toksynami grzybów pleśniowych zawartych w paszach i żywności. Woda - Środowisko - Obszary Wiejskie 14, 3(47), 160-168.

Zawadzki A., Szuba-Trznadel A., Fusch B., 2011. Baza pokarmowa, charakterystyka populacji i sezonowość rozrodu dzików na terenie Gór Kaczawskich. Zesz. Nauk. UP we Wrocławiu. Biologia i Hodowla Zwierząt 63, 363-376. 


\author{
Jan Zdulski ${ }^{1,4}$, Witold Chabuz ${ }^{1}$, Wioletta Sawicka-Zugaj ${ }^{1}$, Aneta Krawiec ${ }^{2}$, \\ Karol Szulc ${ }^{2}$, Magdalena Stobiecka
}

\title{
Wypas pastwiskowy jako czynna forma ochrony przyrody
}

Pasture grazing as an active form of nature protection

Działalność człowieka nieodwracalnie zmienia otaczający go świat. Nauczyliśmy się dostosowywać swoje środowisko do naszych potrzeb, w przeciwieństwie do innych gatunków. Pierwszym z takich działań w rozwoju cywilizacji było rolnictwo. Antropopresja to określenie na niekorzystny proces prowadzący do zniszczenia wielu nisz ekologicznych, z czym wiąże się zanikanie gatunków roślin i zwierząt. Przykładem może być ciągłe wycinanie i wypalanie lasów w celu przygotowania ziemi pod uprawę i hodowlę. Doprowadziło to do zaburzenia stosunków wodnych, erozji terenu, zanieczyszczenia środowiska i zagłady wielu gatunków. Ma to zasięg globalny, gdyż zanieczyszczenia wędrują szlakami troficznymi i wpływają na ekosystemy w odległych miejscach na Ziemi, co skutkuje wykrywaniem środków chemicznych, używanych w rolnictwie, w tkankach oceanicznych organizmów okołobiegunowych, niemających bezpośredniego kontaktu z tymi substancjami. Człowiek, przez swoją krótkowzroczność oraz zaniedbania, wprowadza do środowiska gatunki inwazyjne lub niebezpieczne, jak: stonka ziemniaczana, mrówka faraona lub afrykańska pszczoła zabójca, które ciężko jest kontrolować i które, stanowią poważne zagrożenie dla życia, także ludzi [Jankowska-Huflejt 2007, Boroń i Simon 2010]. Działalność człowieka przynosi jednak nie tylko szkody, ale również stwarza wiele możliwości dla przyrody. Skutkiem gospodarki ludzkiej, oprócz upraw roślin, był wypas zwierząt. Wycinka lasów oraz adaptacja naturalnych łąk wyżynnych, górskich oraz polan przyczyniła się do powstania zbiorowisk roślinnych, wykazujących wyjątkowe bogactwo gatunków flory i fauny. Pastwiska takie stwarzały dogodne warunki do wzrostu wielu światłolubnych roślin czy lęgów niektórych ptaków. Wieloletnie tradycyjne wykorzystanie tych siedlisk sprawiło, że są one wyjątkowo cenne przyrodniczo, gdyż odbiegają wyglądem od podobnych siedlisk nizinnych, co skutko-

\footnotetext{
1 Zakład Hodowli i Ochrony Zasobów Genetycznych Bydła, Instytut Hodowli Zwierząt i Ochrony Bioróżnorodności, Uniwersytet Przyrodniczy w Lublinie

${ }^{2}$ Studenckie Koło Naukowe Nauk o Zwierzętach i Biogospodarki, Sekcja Hodowli Bydła, Uniwersytet Przyrodniczy w Lublinie

${ }^{3}$ Instytut Oceny Jakości i Przetwórstwa Produktów Zwierzęcych, Uniwersytet Przyrodniczy w Lublinie

${ }^{4}$ e-mail: janzdu@wp.pl
} 
wało dostosowaniem się roślin i zwierząt do panujących warunków i wytworzeniem lokalnych odmian czy ras [Wasiak 2011, Szary 2014, Chabuz i in. 2019].

\section{Bioróżnorodność}

Zachowanie różnorodności biologicznej jest kluczowym aspektem dla utrzymania podstawowych systemów i procesów ekologicznych oraz zachowania różnorodności genetycznej. Termin biological diversity (różnorodność biologiczna) został stworzony w 1980 r. przez Thomasa Lovejoya. Został doprecyzowany i ujednolicony podczas Szczytu Ziemi w Rio de Janeiro w 1992 r. [Urbisz 2010]. Polska jako jeden z pierwszych krajów rozpoczęła ochronę gatunkową oraz zachowanie zasobów genetycznych zwierząt (ochrona wewnątrzgatunkowa). W latach 20. XX w. rozpoczęto program restytucji żubrów, hodowlę zachowawczą konika polskiego w rezerwacie leśnym, jednak dopiero w $1996 \mathrm{r}$. Krajowy Ośrodek Koordynacyjny sformalizował i przyczynił się do rozwinięcia tych działań. Położenie naszego kraju, poprzez jego topografię, warunki klimatyczne oraz krajobrazowe, sprzyja zachowaniu mnogości gatunków. Na obszarze Polski zarejestrowano ok. 60 tys. gatunków, z czego 35 tys. to gatunki zwierząt [Urbisz 2010, Szulc 2011]. W krajobrazie wiejskim główną bazę gatunkową stanowią organizmy zasiedlające łąki oraz pastwiska. Istotne dla zachowania wielu gatunków są również zadrzewienia śródpolne, czy też coraz rzadziej spotykane oczka wodne i zmniejszające się miedze. Ich istnienie zapewnia wysokie rozdrobnienie gospodarstw oraz zróżnicowanie upraw, a w mniej zmechanizowanych gospodarstwach również wypas. Zagrożenie dla różnorodności stanowi więc zaprzestanie gospodarowania na terenach rolniczych oraz kolektywizacja i mechanizacja rolnictwa. Uproszczenie uprawy poprzez łączenie wielu małych gospodarstw w wielkie areały obsiane monokulturą znacząco wpływa na obniżenie ilości zwierząt i roślin w środowisku. Nie bez znaczenia jest również mechanizacja produkcji zwierzęcej. Zanik gospodarowania na użytkach zielonych i przekształcanie ich w pola uprawne pod kukurydzę powoduje zniszczenie wielu siedlisk cennych przyrodniczo [Szewczyk 2006, Dembek 2012, Chabuz i in. 2019].

\section{Ochrona cennych siedlisk}

Jedną z form ochrony przyrody jest park narodowy. Pierwszym na świecie był Yellowstone utworzony w $1872 \mathrm{r}$. w celu ochrony całej flory i fauny, znajdującej się na jego terenie, dla przyszłych pokoleń. Do powstania tego typu parku przyczynia się inwentaryzacja flory i fauny oraz określenie cennych siedlisk. Pod uwagę brane są gatunki rzadkie oraz zagrożone, endemity, relikty czy gatunki znajdujące się na listach i zaleceniach do ochrony. Gdy miejsce występowania nie podlega zmiennym warunkom, można zastosować ochronę bierną oraz monitoring. Niestety wiele gatunków występuje w siedliskach niestabilnych, 
o zmiennych warunkach, podlegających zmianom sukcesyjnym. W tym przypadku stosuje się czynne formy ochrony przyrody, jak koszenie czy wypas. W zależności od występowania chronionego gatunku można prowadzić go na małą skalę, np. poprzez usuwanie konkurencji lub pobieranie ze środowiska np. nasion i ponowną introdukcję. Dotyczy to jednak skrajnie zagrożonych populacji. Na większą skalę wskazane są również inne rozwiązania [Zemanek 2007]. Tomasiewicz [2005] opisuje powstawanie polan w Górach Gorczańskich oraz ich wagę dla środowiska. Większość tych systemów powstała na skutek rabunkowej gospodarki leśnej (zapotrzebowania na drewno) przy przemyśle hutniczym oraz papierniczym rozwijającym się na tym terenie. Pozostałe są głównie wynikiem wypasu i wycinki drzewostanu pod pola uprawne. Mimo że polany są tworem pracy rąk ludzkich i nie zajmują dużej powierzchni Parku, są cenną oazą bioróżnorodności. Występuje tam ok. 35\% z 850 gatunków roślin naczyniowych odnotowanych na terenie Gorczańskiego Parku Narodowego. Bogactwo fauny to ponad 1000 gatunków bezkręgowców, nietoperze (mroczek posrebrzany i pozłocisty) czy rzadkie ptaki, jak świergotek drzewny. Ekosystemy takie stwarzają dogodne warunki do toków głuszca i cietrzewia oraz miejsce polowania pustułek i puszczyka. Zaprzestanie użytkowania polan przez człowieka doprowadziło do zmian w strukturze florystycznej poprzez sukcesję bardziej ekspansyjnych roślin. Odnotowano zmniejszenie się ilości storczykowatych, żurawiny i rosiczki, które przegrywają konkurencję z malinami czy borówką. W celu ograniczenia ekspansji wprowadzono koszenie, które niestety przyczynia się do protekcji gatunków

Tabela 1. Udział gatunków roślin z poszczególnych klas fitosocjologicznych na stanowiskach wypasanych i niewypasanych [Chabuz i in. 2012]

\begin{tabular}{|l|c|c|}
\hline \multirow{2}{*}{ Klasa fitosocjologiczna } & \multicolumn{2}{|c|}{ Liczba gatunków } \\
\cline { 2 - 3 } & brak wypasu & wypas \\
\hline Alnetea glutinosae & 1 & - \\
Artemisietea & 2 & 2 \\
Epilobietea angustifolii & 1 & - \\
Festuco-Brometea & 8 & 4 \\
Koelerio glaucae-Corynephoretea canescentis & 1 & 1 \\
Molinio-Arrhenatheretea & 31 & 35 \\
Nardo-Callunetea & 2 & 1 \\
Querco-Fagetea & 2 & 1 \\
Quercetea robori petraeae & 1 & 1 \\
Scheucerio-Caricetea & 1 & 1 \\
Stellarietea mediae & 13 & - \\
Trifolio-Geranietea sanguinei & 4 & 57 \\
\hline Razem & 67 & \\
\hline
\end{tabular}

odpornych na koszenie w ekosystemach traworoślowych, ziołoroślowych i łąkowych [Tomasiewicz 2005]. Chabuz i in. [2012], w swoich badaniach nad wpływem wypasu lokalnych ras bydła na bioróżnorodność Polesia Lubelskiego, 
zauważyli nieznaczne zmniejszenie ilości taksonów roślin naczyniowych na wypasanych stanowiskach (tab. 1). Mimo to, zapobieganie sukcesji wtórnej oraz tworzeniu dogodnych warunków do rozwoju awifauny można uznać za ochronę bioróżnorodności. Potwierdzeniem tego jest występowanie kilku skupisk chronionego goździka Dianthus superbus jedynie na terenie wypasu, pomimo bezpośredniego sąsiedztwa łąki niewypasanej, gdzie go nie odnotowano.

\section{Zbiorowiska trawiaste}

Ekosystemy łąkowo-pastwiskowe wykazuja mozaikowate rozmieszczenie gatunków. Roślinność je porastająca to najczęściej rośliny wieloletnie, mniej wrażliwe na zmiany warunków klimatycznych, tworzące specyficzne zbiorowiska roślinne. Przeważają na nich trawy, a rośliny motylkowe i zioła stanowią mniejszość. Rzadkością są krzewy i drzewa, co skutkuje lepszą ekspozycją roślin na promieniowanie słoneczne. Pasza pozyskana z pastwisk w naszej szerokości geograficznej jest lepsza niż z północnych rejonów, ponieważ rośliny, mając dostęp do większej ilości promieni słonecznych, wytwarzają więcej cukrów [Burczyk i in. 2018]. Ruń łąkowa jest jedną z najtańszych pasz, otrzymywaną najniższym kosztem podczas wypasu. Pastwiska są integralną częścią gospodarstwa, gdyż współdziałają ze zwierzętami i polem uprawnym w obiegu materii. Bez zrównoważonego gospodarowania na użytkach zielonych nie otrzymamy odpowiednio wysokich plonów siana oraz zielonki. Ważne jest, by odpowiednio pielęgnować takie zbiorowiska, gdyż pełnią one wiele funkcji pozaprodukcyjnych. Łąki dzięki trwałemu pokryciu powierzchni gleby biorą udział w retencji wody i jej obiegu w przyrodzie. Zapobiegają zbyt szybkiemu uwolnieniu wody do atmosfery, ale również powstrzymują wymywanie składników mineralnych w głąb gleby. Według Jankowskiej-Huflejt [2007] odpływ azotu z gruntów rolnych jest 5-7-krotnie wyższy w porównaniu z użytkami zielonymi przy zastosowaniu $120 \mathrm{~kg} \mathrm{~N} / \mathrm{ha}$. Roślinność pastwiskowa jest jedną z barier, która utrudnia migrację związków chemicznych (nawozów i środków ochrony roślin) z sąsiadujących pól uprawnych, podobnie jak zadrzewienia śródpolne. Wypas oraz koszenie jest jednym $\mathrm{z}$ narzędzi pozwalających utrzymać ten ekosystem w dobrej kondycji z zachowaniem użyteczności dla produkcji w gospodarstwie, w przeciwieństwie do terenów porośniętych drzewami i krzewami. W przypadku braku wypasu dochodzi to sukcesji wtórnej i zaniku tego specyficznego siedliska. Rośliny łąkowe są w stanie zatrzymać spływającą wodę oraz oczyścić ją przez obecność mikroorganizmów glebowych w górnej warstwie ziemi. Gęsta i wyższa roślinność może nawet zatrzymać część parującej wody, która wraca w postaci skroplonej mgły lub rosy. Wiąże się to również z oczyszczaniem atmosfery z CO 2 . Roślinność może pobierać do $150 \mathrm{~kg} \mathrm{CO}_{2} /$ ha, przy jednoczesnej produkcji $100 \mathrm{~kg} \mathrm{O}_{2} /$ ha. Najważniejszym jednak powodem utrzymania trwałych użytków zielonych (TUZ), oprócz dostarczania paszy, jest zapobieganie erozji gleby. 
Wietrzenie spowodowane uprawą przyczynia się do rozpadu warstwy próchnicznej, odpływu soli mineralnych $\mathrm{w}$ głąb ziemi oraz niszczeniu struktury gleby zapewniającej odpowiednie stosunki wodno-tlenowe potrzebne roślinom [Szewczyk 2006, Jankowska-Huflejt 2007, Wasilewski 2009, Chabuz i in. 2012]. TUZ na całym globie zajmują ponad $3 \mathrm{mld}$ ha powierzchni, czyli ok. 23\% obszarów lądowych. W naszym kraju nie przekraczają $10 \%$ powierzchni i stanowi nieco ponad $20 \%$ użytków rolnych. Dla porównania w Niemczech łąki i pastwiska stanowią ponad $40 \%$ wszystkich użytków rolnych. Trwałe użytki zielone dostarczają naturalnej i wartościowej paszy. W gospodarstwach wysokoprodukcyjnych stanowi ona ok. $50 \%$ dawki pokarmowej, a w ekstensywnych nawet do $100 \%$. Latem pozyskuje się i skarmia zielonkę, a siano i kiszonkę zostawia na zimę. Areał TUZ stanowi $77,4 \%$ powierzchni paszowej kraju, która jest miernikiem powiązania produkcji zwierzęcej z obszarem gruntów rolnych w gospodarstwie [Wasilewski 2009, Burczyk i in. 2018]. Górskie użytki zielone w naszym kraju ograniczają się głównie do Sudetów i Karpat. Można wśród nich wyróżnić 3 strefy wysokościowe: 300-500 m n.p.m. (łąki i pastwiska podgórskie), 500-1000 m n.p.m. (górskie) i pow. $1000 \mathrm{~m}$ n.p.m. (wysokogórskie). W latach 70. ub. wieku pastwiska w strefie wysokościowej 300-700 m n.p.m. stanowiły ok. 30\%, a 700-100 m n.p.m. 60\%. Obecnie proporcje te wynoszą 50 i 95\% [Szewczyk 2006].

Jak podają Twardy $i$ in. [2017], plon nienawożonej runi w znacznym stopniu uzależniony jest od czynników pogodowych. Według ich badań średni plon z bardzo mokrego roku wyniósł $4,1-4,8 \mathrm{t} \cdot \mathrm{ha}^{-1}$, a w roku o średnim poziomie opadów 2,8-3,4 t $\cdot \mathrm{ha}^{-1}$. Na wielkość plonu miało wpływ również wzniesienie terenu. Rejestrowano wyższe plony $\mathrm{w}$ partiach dolinowych i dolinowo-stokowych, najmniej zaś w położeniu stokowo-szczytowym. Plon ze stoku o ekspozycji północnej zawsze był wyższy o ok. 15\% niż plon ze stoku o ekspozycji południowej.

\section{Wypas jako metoda ochrony}

Celem obecnej polityki rolnej jest zahamowanie zmniejszania się bioróżnorodności na terenach rolniczych. Istotnym elementem tego procesu jest przywrócenie ekstensywnego wypasu zwierząt wraz z dostosowaniem obsady do powierzchni, siedliska i gatunków występujących na wypasanym terenie. Aby dodatkowo zapobiegać sukcesji wtórnej, należy nie dopuszczać do rozwoju roślinności drzewiastej oraz inwazyjnej, np. poprzez koszenie [Wasilewski 2009, Szary 2014, Chabuz i in. 2019].

Działalność człowieka, a przede wszystkim rolnictwo, ukształtowały krajobraz wielu miejsc na świecie przez kilkusetletnią obecność i zmiany, jakie były wprowadzane w środowisku. Przykładem może być Wyżyna Krakowsko-Częstochowska, będąca miejscem niesprzyjającym rolnictwu. Ze względu na wyżynny charakter, niedostatek wody i wapienną glebę ludzie skupiali osady wokół źródeł i rzek. $\mathrm{Z}$ czasem zaczęto uniezależniać się poprzez zbieranie deszczówki czy kopanie studni. 
Przyczyniło się to do rozwoju wypasu zwierząt, zwłaszcza owiec i kóz, na dość ubogich terenach piaszczystych i w lasach. Wraz ze wzrostem ludności wzrastało zapotrzebowanie na opał i wycinano coraz więcej lasów. Wszystkie ziemie nadające się do uprawy były przeznaczane na produkcję żywności, natomiast kozy i owce wypasano w wyższych partiach wzgórz oraz suchych dolinach. W XX w. po odgórnym zakazie wypasu zwierząt w lasach zaobserwowano zanikanie wrzosowisk. W ostatnich latach przez nieopłacalność produkcji zaprzestano wypasu na jurajskich wzgórzach. Przyczyniło się to do ekspansji krzewów oraz drzew na skalne pastwiska, co było bezpośrednią przyczyną zanikania muraw kserotermicznych z powodu zacienienia. Przywrócenie wypasu wspomaga rozwój roślin pomijanych przez zwierzęta, najczęściej niesmacznych lub trujących, kosztem pozostałych zmniejszając konkurencję. Gatunki te zawierają w swoich komórkach najczęściej niekorzystne dla przeżuwaczy składniki, jak alkaloidy, saponiny czy glikozydy. Tworzy się dzięki temu charakterystyczny zestaw roślin. Zwierzęta swoimi racicami w tym przypadku ułatwiają spływ warstwy próchniczej nagromadzonej podczas braku wypasu, co sprzyja tworzeniu się nisz i powrotowi gatunków roślinności murawowej (zwiększenie zróżnicowania mikrosiedliskowego) [Czylok i in. 2010, Chabuz i in. 2019].

$\mathrm{Z}$ powodu niskich przychodów podczas utrzymania zwierząt ras rodzimych wprowadzono dopłaty mające rekompensować poniesione straty. Pomimo lepszego wykorzystania dostępnej paszy i wyższej zdrowotności wykazują one niższą produkcyjność. Zwierzęta, zgryzając biomasę, dostarczają naturalny nawóz z powrotem na pole. Zapewnia to obieg materii i zapobiega przeżyźnieniu. Obłamywanie i udeptywanie suchych liści, traw i gałązek przyczynia się do zabezpieczenia pastwisk przez samoistnym zapłonem, ograniczając dostęp powietrza i zwiększając wilgotność ściółki. Działanie to przyśpiesza również gnicie masy roślinnej, a racice zwierząt napowietrzają lub ubijają glebę, regulując stosunki powietrzne. Dlatego ważna jest znajomość gleby i stosunków powietrznowodnych, aby poprawiać strukturę ziemi i dobrać odpowiednią obsadę. Zgryzanie siewek drzew i krzewów zapobiega sukcesji wtórnej oraz pozwala na kiełkowanie niektórych gatunków. Selektywność w wyborze pokarmu owocuje mozaikowatą strukturą roślinności. Takie zróżnicowanie jest sprzyjające gniazdowaniu różnych rodzajów ptaków. W zależności od gatunku, niektóre wolą gniazdować w zaroślach, inne zakładają gniazda w niskiej trawie. Zapewnia to również różnorakie schronienia dla bezkręgowców, będących pokarmem awifauny [Kucharska 2005, Chabuz i in. 2012, 2019]. Chabuz i in. [2012] w swoich badaniach obserwowali wpływ wypasu m.in. na różnice w ilości zasiedlających teren ptaków. Po obserwacji stwierdzono, że wypas lokalnych ras bydła sprzyja gniazdowaniu ptaków łąkowo-pastwiskowych i zwiększa bioróżnorodność (tab. 2).

Różne gatunki zwierząt gospodarskich z uwagi na inne preferencje pokarmowe, a przede wszystkim wagę, mogą być wykorzystywane na różnorakich siedliskach użytków zielonych. W Biebrzańskim Parku Narodowym (BPN) do tego celu wykorzystano koniki polskie. Na podmokłych pastwiskach koniki spisują się znacznie 
Tabela 2. Liczebność obserwowanych ptaków lęgowych i nielęgowych na badanym obszarze [Chabuz i in. 2012]

\begin{tabular}{|c|c|c|c|c|}
\hline \multirow[b]{2}{*}{ Gatunek } & \multicolumn{2}{|c|}{ Wypas } & \multicolumn{2}{|c|}{ Brak wypasu } \\
\hline & $\begin{array}{l}\text { pary } \\
\text { lęgowe }\end{array}$ & $\begin{array}{c}\text { gatunki } \\
\text { nielęgowe- } \\
\text { liczebność } \\
\text { ptaków } \\
\text { żerujących }\end{array}$ & $\begin{array}{c}\text { pary } \\
\text { lęgowe }\end{array}$ & $\begin{array}{c}\text { gatunki } \\
\text { nielęgowe- } \\
\text { liczebność } \\
\text { ptaków } \\
\text { żerujących }\end{array}$ \\
\hline Skowronek Alauda arvensis & $7-8$ & - & 3 & - \\
\hline Cierniówka Sylvia communis & $2-3$ & - & - & - \\
\hline Pokląskwa Saxicola rubetra & $1-2$ & - & 1 & - \\
\hline Bażant Phasianus colchicus & 1 & - & - & - \\
\hline Bogatka Parus major & 1 & - & - & - \\
\hline Czajka Vanellus vanellus & 1 & - & - & - \\
\hline Derkacz Crex crex & 1 & - & 1 & - \\
\hline Kos Turdus merula & 1 & - & - & - \\
\hline Pliszka siwa Motacilla alba & 1 & - & - & - \\
\hline pliszka żółta Motacilla flava & 1 & - & - & - \\
\hline Potrzeszcz Emberiza calandra & 1 & - & - & - \\
\hline Przepiórka Coturnix coturnix & 1 & - & - & - \\
\hline Trznadel Emberiza citrinella & 1 & - & 1 & - \\
\hline Wrona siwa Corvus cornix & $0-1$ & - & - & - \\
\hline Dymówka Hirundo rustica & - & 19 & - & - \\
\hline Szpak Sturnus vulgaris & - & 14 & - & 2 \\
\hline Śmieszka Chroicocephalus ridibundus & - & 14 & - & - \\
\hline Mazurek Passer montanus & - & 8 & - & - \\
\hline Sroka Pica pica & - & 5 & - & - \\
\hline Szczygieł Carduelis carduelis & - & 5 & - & - \\
\hline Makolągwa Carduelis cannabina & - & 4 & - & - \\
\hline Grzywacz Columba palumbus & - & 3 & - & - \\
\hline Kapturka Sylvia atricapilla & - & 2 & - & - \\
\hline Kruk Corvus corax & - & 2 & - & - \\
\hline Błotniak stawowy Circus aeruginosus & - & 1 & - & 1 \\
\hline Błotniak łąkowy Circus pygargus & - & - & - & 1 \\
\hline Bocian biały Ciconia ciconia & - & 1 & - & 1 \\
\hline Gąsiorek Lanius collurio & - & 1 & - & 1 \\
\hline Kopciuszek Phoenicurus ochruros & - & 1 & - & - \\
\hline Oknówka Delichon urbicum & - & 1 & - & - \\
\hline Orlik krzykliwy Aquila pomarina & - & 1 & - & - \\
\hline Piecuszek Phylloscopus trochilus & - & 1 & 1 & - \\
\hline Pierwiosnek Phylloscopus collybita & - & - & - & 1 \\
\hline Sójka Garrulus glandarius & - & 1 & - & 3 \\
\hline Srokosz Lanius excubitor & - & 1 & - & - \\
\hline Dzięciołek Dendrocopos minor & - & - & - & 1 \\
\hline Śmieszka Chroicocephalus ridibundus & - & - & - & 2 \\
\hline Liczba gatunków & 14 & 19 & 5 & 9 \\
\hline
\end{tabular}


lepiej niż człowiek i koszenie. Zwierzęta kopytami zagęszczają i udeptują podłoże oraz zgryzają najczęściej występujące rośliny. Przyczynia się to do zwiększenia ilości gatunków występujących na terenie parku. Do wypasu wybrano rasę prymitywną, ze względu na doskonałe wykorzystanie paszy przy wysokiej odporności i niskich wymaganiach. Koniki są lżejsze od bydła i koni, więc lepiej sprawdzają się na terenach podmokłych. Badania w BPN wskazały, że zwierzęta te częściej wybierają rośliny omijane przez inne gatunki. $\mathrm{W}$ ich diecie dominowały rośliny jednoliścienne. Koniki najchętniej wybierały turzycę prosowatą (Carex paniea L.), turzycę żóltą (Carex flava L.), trzęślicę modrą (Molinia caerulea L.) oraz mietlicę psią (Agrostis canina L.). Pozostałe zgryzane gatunki stanowiły poniżej $2 \%$ diety [Chodkiewicz i Stypiński 2011].

Badania Nadolnej [2013] nad zróżnicowaniem flory pastwiskowej w Sudetach wskazują, iż na $14(82 \%)$ przebadanych stanowiskach odnotowano więcej niż 40 gatunków ogółem, a zatem można zaliczyć je do użytków zielonych o dużej bioróżnorodności. Średnio na pastwiskach występowało 17-28 gatunków. Liczba ziół i chwastów w składzie tych użytków przekroczyła 65\%. Pastwiska przydomowe charakteryzowały się znacznie niższym bogactwem gatunkowym. Średnio zaobserwowano 7-11 gatunków roślin. Wynikać to może z bardziej intensywnego użytkowania pastwisk przydomowych, co wpływa niekorzystnie na skład i strukturę runi. Szary [2004] w swojej pracy na temat dynamiki roślinności łąkowej pod wpływem koszenia i wypasu w Bieszczadzkim Parku Narodowym zaobserwował, iż nieregularne koszenie powierzchni powoduje brak stabilności, jaką wykazują fitocenozy od lat poddawane tym zabiegom. Po 12-letniej obserwacji odnotowano spadek liczby gatunków roślin naczyniowych na areale niekoszonym $\mathrm{w}$ porównaniu $\mathrm{z}$ koszonym, $\mathrm{z}$ uzupełnieniem wypasu ekstensywnego. Podobne wnioski sformułowały Pławska-Olejniczak i Żywiczka [2009]. Obserwując wpływ koszenia i wypasu na florę naczyniową łąk, zauważyły wzrost liczby taksonów w kolejnych latach użytkowania pastwiskowego, co świadczy o pozytywnym wpływie tej metody. Co ciekawe wpływ ten był wyraźniejszy na terenach wypasu szkockiego bydła górskiego. Koniki polskie podczas wypasu zmniejszały wskaźnik bioróżnorodności pastwiska, jednak poprawiły jego wartość użytkową (obserwowano wzrost udziału gatunków o wyższej wartości pokarmowej). W obu przypadkach zaobserwowano wzrost liczby taksonów światłolubnych, co świadczy o ustępowaniu roślin wysokich.

\section{Murawy kserotermiczne jako wyjątkowe użytki zielone}

Murawy kserotermiczne to wyjątkowe siedliska roślinne, o specyficznej budowie szaty roślinnej. Należą do jednych z najbardziej zróżnicowanych i bogatych w gatunki biocenoz. Ich występowanie uzależnione jest od kilku czynników. Warunki klimatyczne muszą wykazywać wysokie temperatury latem, z przewagą parowania nad opadami. W słoneczne dni niekiedy temperatura przy gruncie może 
osiągać do $50^{\circ} \mathrm{C}$. Murawy takie najczęściej znajdują się na stokach i zboczach o ekspozycji południowej lub południowo-wschodniej lub południowo-zachodniej, a podłoże powinno być zasadowe lub obojętne, bogate w węglan wapnia. Ze względu na klimat w Polsce i ukształtowanie terenu ten typ zbiorowisk roślinnych jest u nas dość rzadki, w porównaniu z południem Europy. Dodatkowo przez swoją małą powierzchnię i dużą wrażliwość te wyjątkowo cenne siedliska są zagrożone zniszczeniem. Podobnie jak inne TUZ cierpią one przez brak ekstensywnego wypasu i wtórną sukcesję lasu. Również nawożenie dostarczające zbyt wielu składników mineralnych powoduje wzrost gatunków, które są konkurencją dla flory muraw kserotermicznych [Banach 2010]. Roślinność ta nie jest natywna dla obszaru Polski, przywędrowała w okresie postglacjalnym i zaadaptowała się do naszych warunków. Wskazówką co do antropogenicznego pochodzenia muraw kserotermicznych jest fakt, że wymagają one do swojego istnienia interwencji człowieka, w postaci prowadzonego wypasu [Kostuch i Misztal 2007, Twerd i Banaszak 2013].

Człowiek od zawsze zmieniał środowisko dla własnych potrzeb. Zazwyczaj te zmiany służyły jedynie rozwojowi ludzi, szkodząc środowisku. Dzięki działalności człowieka powstały lub zostały zachowane trawiaste zbiorowiska roślinne będące łąkami oraz pastwiskami. Gospodarka trwałymi użytkami zielonymi zapewnia im istnienie przez ograniczenie wtórnej sukcesji roślin wyższych i stwarza dogodne warunki rozwoju dla wielu gatunków roślin i zwierząt. Ekstensywny wypas zwierząt zapewnia istnienie jednej z najbogatszych biocenoz naszego kraju - muraw kserotermicznych. Wypas zwierząt gospodarskich wprowadzono jako formę czynnej ochrony zbiorowisk trawiastych w wielu parkach narodowych w Polsce. Zwierzęta wykazują selektywne pobieranie pokar$\mathrm{mu}$ oraz swoją obecnością wpływają na warunki glebowe. Zastosowanie tego rozwiązania skutkuje zwiększeniem bioróżnorodności roślin i zwierząt (głównie ptaków) na danym obszarze oraz lepszymi efektami od koszenia. Wypas odpowiednio dobranego gatunku i rasy przy właściwej obsadzie do stanowiska, zapewnia pozytywny wpływ na cały lokalny ekosystem.

\section{Bibliografia}

Boroń M., Simon R., 2016. Wpływ czynników antropogenicznych na bioróżnorodność owadów. Med. Środow. 19(3), 65-69.

Banach M., 2010. Utrzymanie bioróżnorodności siedlisk kserotermicznych w Małopolsce. Stud. I Mat. CEPL w Rogowie. R 12, 2(25), 248-255.

Burczyk P., Gamrat R., Gałczyńska M., Saran E., 2018. Rola trwałych użytków zielonych w zapewnieniu stanu równowagi ekologicznej środowiska przyrodniczego. Woda - Środowisko Obszary Wiejskie 18(3), 21-37.

Chabuz W., Grzywaczewski G., Rysiak A., Cios Sz., Podolak G., Litwińczuk Z., 2012. Wpływ wypasu lokalnych ras bydła na różnorodność biologiczną łąk i pastwisk Polesia Lubelskiego. Rocz. Nauk. Pol. Tow. Zootech. 8(4), 81-90. 
Chabuz W., Kulik M., Sawicka-Zugaj W., Żółkiewski P., Warda M., Pluta M., Lipiec A., Bochniak A., Zdulski J., 2019. Impact of the type of permanent grasslands areas in mountainous regions on the floristic diversity of habitats and animal welfare. Glob. Eco. Cons. 19, e00629, 1-8, https://doi.org/10.1016/j.gecco.2019.e00629.

Chodkiewicz A., Stypiński P., 2011. Preferencje pokarmowe koników polskich wypasanych w Biebrzańskim Parku Narodowym. Woda - Srodowisko - Obszary Wiejskie 11(2), 33-42.

Czylok A., Korczyński T., Murawski M., Sikora J., Smętek J., Stefaniak K., Ślusarczyk M., Tyc A., Waga J.M., 2010. Wypas zwierząt gospodarskich jako element ochrony różnorodności krajobrazowej i biologicznej Wyżyny Krakowsko-Częstochowskiej. W: Czylok A., Ślusarczyk M., Waga J.M. (red.) Owce w krajobrazie Wyżyny Krakowsko-Częstochowskiej. Towarzystwo Miłośników Ziemi Zawierciańskiej, Zawiercie, 58-80.

Dembek W., 2012. Problemy ochrony polskiej przyrody w kontekście wspólnej polityki rolnej. Woda - Srodowisko - Obszary Wiejskie 12(4), 109-121.

Jankowska-Huflejt H., 2007. Rolnośrodowiskowe znaczenie trwałych użytków zielonych. Probl. Inż. Rol. 1, 23-34.

Kostuch R., Misztal A., 2007. Roślinność kserotermiczna istotnym elementem bioróżnorodności wyżyny małopolskiej. Woda - Środowisko - Obszary Wiejskie 7(2b), 99-110.

Kucharska A., 2005. Programy rolnośrodowiskowe z udziałem zwierząt trawożernych szansą na utrzymanie naturalnych i półnaturalnych łąk i pastwisk oraz ich bioróżnorodności. Chem. Dyd. Ekol. Metr. 10(1-2), 29-32.

Nadolna L., 2013. Znaczenie sudeckich pastwisk w ochronie różnorodności florystycznej i wartości użytkowej. Inż. Ekol. 33, 77-84.

Pławska-Olejniczak J., Żywiczka A., 2009. Wpływ wypasu Koników Polskich i Szkockiego Bydła Górskiego na florę naczyniową ekstensywnie użytkowanych Łąk Skoszewskich. Łąkarstwo w Polsc. 12, 131-141.

Szary A., 2014. Dynamika roślinności łąkowej pod wpływem koszenia i wypasu w Biszczadzkim Parku Narodowym. Rocz. Bieszcz. 22, 203-212.

Szewczyk W., 2006. Racjonalne nawożenie łąk i pastwisk. Program Aktywizacji Gospodarczej i Ochrony Dziedzictwa Małopolskich Karpat. Owca Plus 2006. Mat. Szkoleniowe. Wyd. AR w Krakowie, Instytut Botaniki PAN w Krakowie, 70-80.

Szulc K., 2011. Ochrona zasobów zwierząt gospodarskich w kontekście zrównoważonego rozwoju. Probl. Ekorozw. 6(8), 141-146.

Tomasiewicz J., 2005. Wpływ działalności człowieka na kształtowanie i utrzymanie bioróżnorodności gorczańskich polan. W: A. Hibszer, J. Partyka (red.), Między ochroną przyrody a gospodarką - bliżej ochrony. Polskie Tow. Geograficzne Oddział Katowicki, Ojcowski Park Narodowy, 43-52.

Twardy S., Domagała B., Matoga W., 2017. Wartość gospodarcza runi pastwiska górskiego ekstensywnie użytkowanego, położonego na przeciwległych stokach (N-S). Woda - Środowisko Obszary Wiejskie 17(4), 129-146.

Twerd L., Banaszak J., 2013. Problemy ochrony fauny termokserofilnej pszczół (Hymenoptera: Apoidea, Apiformes) na przykładzie rezerwatu „Góra Gipsowa”. Inż. Ekonom. 33, 147-155.

Urbisz A., 2010. Ocena bioróżnorodności jako jeden $\mathrm{z}$ ważnych warunków ekorozwoju. Probl. Ekorozw. 5(1), 91-94.

Wasiak P., 2011. Zespoły ptaków lęgowych łąk i pastwisk w Górach Kamiennych (Sudety Środkowe). Ptaki Śląska, 18, 61-88.

Wasilewski Z., 2009. Stan obecny i kierunki gospodarowania na użytkach zielonych zgodnie z wymogami wspólnej polityki rolnej. Woda - Środowisko - Obszary Wiejskie 9(2), 169-184.

Zemanek B., 2007. Rola parków narodowych w ochronie rzadkich i ginących gatunków roślin naczyniowych. Rocz. Bieszcz. 15, 35-40. 
Wojciech Ospałek ${ }^{1,3}$, Wiktoria Polit ${ }^{1}$, Nina Mickiewicz ${ }^{1}$, Agata Satowska ${ }^{1}$, Agata Domagała ${ }^{1}$, Łukasz Wlazło $^{2}$, Bożena Nowakowicz-Dębek ${ }^{2}$

\section{Wpływ długości fal świetlnych na rozwój mikroorganizmów}

The impact of wavelengths of light on the growth of microorganisms

Światło, nazywane inaczej promieniowaniem optycznym, to pojęcie wywodzące się z fizyki. Jest to promieniowanie elektromagnetyczne o fali długości w zakresach od $380 \mathrm{~nm}$ (barwa fioletowa) do $760 \mathrm{~nm}$ (barwa czerwona). Tym mianem określa się też promieniowanie podczerwone i promieniowanie nadfioletowe - oba te rodzaje mają podobne właściwości. Może być pochodzenia naturalnego, ale może być też generowane sztucznie. Najsilniejszym źródłem światła docierającym do Ziemi są gwiazdy, a największe natężenie promieniowania pochodzi z powierzchni Słońca. Różnego rodzaju błyski powstają między innymi w wyniku absorpcji promieniowania, reakcji chemicznych, czy poprzez wzbudzenie termiczne albo elektryczne. Światło podobne w budowie do promieniowania słonecznego daje wrażenie barwy białej. Można je podzielić na poszczególne części czy fragmenty, które mają określoną długość fali - dzięki takiemu działaniu otrzymuje się widmo ciągłe o różnym natężeniu (a więc również o różnych barwach), [PWN 2020].

Promieniowanie optyczne jest więc czynnikiem fizycznym, który jest niezbędny do prawidłowego funkcjonowania wielu gatunków organizmów żywych. Odgrywa ogromną rolę w odżywianiu autotrofów, a także reguluje rytm dobowy zwierząt. Wpływa na metabolizm, krążenie krwi i na gospodarkę hormonalną. Jest ważne również dlatego, że umożliwia odbieranie bodźców wzrokowych bez niego oczy nie są w stanie zobaczyć kształtów ani barw. Nie da się podważyć znaczącej roli, jaką odgrywa światło w życiu wielu gatunków zwierząt czy roślin [Łuczycka i Zygmunt 2012, EMIS Professional 2018, Fiutak i in. 2018].

Okazuje się jednak, że określone długości fali elektromagnetycznej mocno oddziałują na różnorodne gatunki mikroorganizmów, które potrzebują ich, aby przetrwać lub wręcz przeciwnie - po zetknięciu z promieniami słońca giną [Matthew $\mathrm{i}$ in. 1878].

\footnotetext{
${ }^{1}$ Studenckie Koło Naukowe Nauk o Zwierzętach i Biogospodarki, Wydział Nauk o Zwierzętach i Biogospodarki, Uniwersytet Przyrodniczy w Lublinie

${ }^{2}$ Katedra Higieny Zwierząt i Zagrożeń Środowiska, Wydział Nauk o Zwierzętach i Biogospodarki, Uniwersytet Przyrodniczy w Lublinie

3 e-mail: wojciecho.poczta@gmail.com
} 


\section{Wpływ fal świetlnych na wybrane mikroorganizmy odgrywające ważną rolę w przemyśle}

Mikroalgi są jednokomórkowymi organizmami, które mogą się rozwijać w rozmaitych siedliskach. Możemy je spotkać w oceanach, ściekach, rzekach, czy na pustyniach. Niektóre z nich są autotrofami - do wzrostu potrzebują światła i dwutlenku węgla. Inne to heterotrofy żyjące w ciemnościach, wytwarzają biomasę dzięki organicznym źródłom węgla. Mikroalgi są z powodzeniem wykorzystywane $\mathrm{w}$ przemyśle spożywczym i kosmetycznym [Metsoviti i in. 2020]. W badaniach Metsoviti i in. [2020] określono jak rodzaj Chlorella vulgaris preferujący wody słodkie reaguje na zmiany natężenia promieniowania słonecznego. W tym celu poddano hodowle działaniu światła w zakresie $420-520 \mathrm{~nm}$ oraz w zakresie $580-680 \mathrm{~nm}$, a także wykorzystano sztuczne oświetlenie LED w kolorze czerwonym i białym. Jedną hodowlę utrzymywano w otwartym, a drugą w zamkniętym bioreaktorze. Okazało się, że intensywniejsze promieniowanie słoneczne, tj. o większej mocy promieniowania na jednostkę powierzchni przy zachowaniu takiej samej długości fali, powoduje szybszy wzrost Chlorella vulgaris w obu hodowlach, a także zwiększa zawartość lipidów w poszczególnych mikroalgach. Wzrost przyspieszył, a zawartość lipidów zwiększyła się również w przypadku zastosowania czerwonych i białych lamp LED [Metsoviti i in. 2020]. Chae-Hun i in. [2016] przeprowadzili badania na gatunkach takich jak Nannochloropsis salina, Nannochloropsis oceanica i Nannochloropsis oculata. Poddano je działaniu sztucznych świateł LED w kolorach czerwonym, zielonym i niebieskim. Hodowle prowadzono w formie dwóch faz: w fazie pierwszej mikroalgi zostały poddane działaniu niebieskich lub czerwonych świateł, w drugiej fazie zastosowano światła zielone. Badanie to miało na celu sprawdzenie, jak długość fali oraz natężenie światła wpływają na wzrost oraz zawartość lipidów w zielonych mikroalgach. Wszystkie trzy gatunki wytwarzały najwyższą biomasę $\mathrm{w}$ niebieskim świetle, a najniższą $\mathrm{w}$ zielonym - zielone światło nie było wchłaniane przez organizmy, tylko odbijane. Z kolei wzrost ilości lipidów był proporcjonalnie odwrotny. Najwyższą zawartością lipidów charakteryzowały się mikroalgi naświetlane zielonym światłem, gdzie lipidy zajmowały od 52 do 56\% masy. Wynika to z faktu, że większe stężenie lipidów pojawia się wtedy, kiedy organizm wolniej rośnie (lipidy są w takiej sytuacji najbardziej produktywne). To badanie wskazuje również, że niezależnie od koloru sztuczne LEDY przyspieszają wzrost mikroalg z gatunków Nannochloropsis salina, Nannochloropsis oceanica i Nannochloropsis oculata, a więc wpływ światła na ich rozwój wydaje się być niepodważalny [Chae-Hun i in. 2016].

W różnych branżach ważną rolę odgrywa Pseudomonas taetrolens - to Gram-ujemna pałeczkowata bakteria, którą wykorzystuje się między innymi do produkcji kwasu laktobionowego z odpadów mlecznych [Jung-Hun 2020].

Już dawno odkryto, że jest to bakteria, która posiada fotoreceptory. Dopiero jednak Chin-Hang i in. [2017] zastanowili się nad problemem, czy ten fakt moż- 
na w jakiś sposób wykorzystać, aby przyspieszyć produkcję kwasu laktobionowego. Do swoich eksperymentów wykorzystali światło o różnych falach i o różnych poziomach natężenia. Czerwone światło wzmocniło wytwarzanie kwasu laktobionowego przez Pseudomonas taetrolens w porównaniu z wynikami z hodowli znajdującej się w ciemności. Niebieskie światło zwiększyło wzrost komórek bakterii, ale obniżyło poziom produkcji kwasu $\mathrm{w}$ porównaniu $\mathrm{z}$ wynikami $\mathrm{z}$ hodowli znajdującej się w ciemności. Najbardziej optymalne warunki dla produkcji kwasu laktobionowego udało się stworzyć przy użyciu dwustopniowego fotobioreaktora LED. W ciągu pierwszych dwunastu godzin wystawiono kolonię na działanie niebieskiego światła, dzięki czemu przyspieszono wzrost bakterii. Następnie uruchomiono czerwone światło. Dzięki takim działaniom czas fermentacji został skrócony o jeden dzień w stosunku do wyników z kolonii, która była naświetlana wyłącznie czerwonym światłem [Chin-Hang i in. 2017]. Te badania mają ogromną wagę, ponieważ kwas laktobionowy ma różnorodne zastosowania w rozmaitych branżach. Wykorzystuje się go w przemyśle chemicznym do produkcji detergentów. Jest też składnikiem roztworów pozwalających na stabilizację narządów przed przeszczepem [Chin-Hang i in. 2017, Jung-Hun 2020]. W przemyśle kosmetycznym wchodzi w skład maseczek czy kremów, które stosuje się w celu „uspokojenia” skóry po różnego rodzaju zabiegach. Warstwa mazidła zawierającego w sobie kwas laktobionowy łagodzi stany zapalne i zwiększa właściwości ochronne skóry [Ruey i in. 2009, Jung-Hun 2020]. Odgrywa on również bardzo ważną rolę w przemyśle spożywczym, w produkcji jogurtów i serów. Kwas ten skraca czas dojrzewania produktów, poprawia ich smak oraz aromat [Saarela i in. 2003, Jung-Hun 2020].

\section{Znaczenie światla w medycynie - drożdżaki}

Badania na temat etiologii chorób dermatologicznych były prowadzone od dawna przez wiele ośrodków naukowych. Niezależnie jednak od czasu, jaki upłynął, wyniki powtarzają się. Doświadczenie przeprowadzone przez McGinleya i in. [1975] miało na celu porównanie składu mikroflory skóry głowy u osób zdrowych i takich, które walczą z łupieżem lub cierpią na łojotokowe zapalenie skóry. U osób chorych występowała zwiększona ilość grzybów Pityrosporum (rząd Malassezia) [McGinley i in. 1975].

W późniejszych latach również badano związek mikroorganizmów z chorobami skóry. Potwierdzono wyniki McGinleya - drożdże z gatunku Malassezia mają związek z łojotokowym zapaleniem skóry, łupieżem, atopowym zapaleniem skóry czy trądzikiem noworodkowym. Czasami są też odpowiedzialne za brak poprawy pomimo stosowanego leczenia, mogą powodować stany zapalne lub uniemożliwiać gojenie się ran. W związku z tym terapia mająca na celu eliminację drobnoustrojów z powierzchni skóry wydaje się być jednym z kluczowych etapów leczenia [Warner i in. 2001]. 
Jednym ze sposobów na walkę z tymi mikroorganizmami może być promieniowanie. Fototerapia to dziedzina, która przez wiele lat nie była uznawana w świecie nauki. Chociaż światło przez wiele lat pomagało w leczeniu różnorodnych chorób, między innymi tych o podłożu dermatologicznym, dopiero niedawno badacze zainteresowali się mechanizmami jego działania. Dzięki temu fotomedycyna zaczęła się prężnie rozwijać. Aktualnie różne eksperymenty potwierdzają, że promieniowanie ultrafioletowe wpływa pozytywnie na leczenie chorób skóry poprzez działanie immunosupresyjne, ale również antybakteryjne czy antygrzybicze [Weichenthal i Schwarz 2005].

Zespół koreańskich naukowców postanowił zbadać przeciwgrzybicze działanie świateł LED przeciwko drożdżakom z rodzaju Malassezia. Mimo że wywołują rozmaite choroby, drożdże należą do naturalnej flory pokrywającej ludzką skórę. Stają się patogenami w szczególnych przypadkach, takich jak osłabienie ogólnej odporności organizmu czy nieodpowiednie zdezynfekowanie rany, którą mogą nadkażać. W celu zbadania wpływu światła na ten rodzaj drożdżaków wykorzystano diody LED o różnych długościach fali w zakresie od $370 \mathrm{~nm}$ do $640 \mathrm{~nm}$. Malassezia furfur, Malassezia sympodialis i Malassezia globosa były naświetlane przez taki sam okres, później określano przeciwgrzybicze działanie poszczególnych fal. Wzrost wszystkich gatunków Malassezia został zatrzymany po zastosowaniu świateł LED o długości fali $380 \pm 2$ i $392,5 \pm 1 \mathrm{~nm}$. Z kolei napromieniowanie drożdży dawką światła poniżej $5 \mathrm{~J} / \mathrm{cm}^{2}$ nie miało żadnego znaczenia. Te wyniki dają nadzieję osobom, które są dotknięte chorobami wywołanymi przez drożdże z gatunku Malassezia [Seung Wi i in. 2012]. Promienie ultrafioletowe równie skutecznie działają na drożdżaki Candida albicans, które są częstą przyczyną zakażeń szpitalnych, prowadzących w niektórych przypadkach nawet do śmierci pacjentów [Farrell i in. 2011].

Medycyna od dawna szuka sposobów na odkażanie powierzchni, które będą skuteczne, a także jak najbardziej bezpieczne dla pacjentów oraz personelu. Okazuje się, że jedną z metod ograniczenia ryzyka infekcji szpitalnych może być pulsacyjne naświetlanie diodami LED, przy użyciu którego oczyszcza się nie tylko powierzchnię, ale również żywność, wodę czy powietrze. Polega to na naświetlaniu obiektów badań za pomocą ultrakrótkich, ale intensywnych i szerokopasmowych impulsów bakteriobójczych (pasmo 200-280 nm) [Farrell i in. 2011].

Badania Farrella i in. [2011] dowodzą związku pomiędzy apoptozą komórek Candida albicans, a stosowaniem zabiegów pulsacyjnych świattem UV. To doświadczenie wskazuje na promienie ultrafioletowe, które inaktywują C. albicans, ponieważ wielokrotne uderzenia światła w komórkę powodują nieodwracalne uszkodzenie DNA i destabilizację plazmatycznej błony komórkowej [Farrell i in. 2011]. 


\section{Wpływ światla na mikroorganizmy zanieczyszczające wodę}

Dezynfekcja wody to duży problem współczesnego świata. Konieczność wykonywania badań dotyczących jej uzdatniania zrodziła się z zapotrzebowania na wodę pitną w regionach oddalonych od dużych społeczności, gdzie nie ma dostępu do kanalizacji [Yumu Lui i in. 2016].

Jedną z najświeższych technologii, która może pomóc w przekroczeniu tej bariery jest wykorzystanie diod emitujących światło ultrafioletowe. Metoda ta od wielu lat wykorzystywana jest w przemyśle. Diody UV posiadają wszystkie pozytywne cechy tradycyjnych żarówek rtęciowych. Dodatkowo są mniejsze, bardziej wytrzymałe i dużo szybciej osiągają pełną moc. Dzięki tym cechom lepiej sprawdzą się jako elementy składowe systemów dezynfekujących wodę w odległych i trudnych terenach, gdzie są narażone między innymi na liczne uszkodzenia mechaniczne [Jarvis i in. 2019].

Badania przeprowadzone przez zespół kanadyjskiego i australijskiego uniwersytetu wydają się potwierdzać możliwość wykorzystania promieniowania świetlnego do dekontaminacji wody. W tym doświadczeniu wykorzystano reaktor modelowy o pojemności 1,3 litra. Porównano 12 różnych układów LED o długości fal od $270 \mathrm{~nm}$ do $740 \mathrm{~nm}$ pod względem ich zdolności do inaktywacji Escherichia coli K12 ATCC W3110 i Enterococcus faecalis ATCC 19433 w ciągu 6 godzin. Wyniki były następujące: dezynfekcję obu gatunków bakterii osiągnięto za pomocą świateł LED o długości fali $270 \mathrm{~nm}$ i $365-455 \mathrm{~nm}$. Naświetlanie falą o długości $310 \mathrm{~nm}$ nie dało żadnych rezultatów. Stwierdzono również, że diody UV-C działają szybciej, ale ze słabszą mocą, natomiast diody UV-A działają wolniej, ale ich wykorzystanie daje dużo lepsze rezultaty. Okazuje się, że dezynfekcja za pomocą diod ledowych jest możliwa i bezpieczna. Można ją stosować w praktyce, z powodzeniem uzdatniając w ten sposób wodę [Yumu Lui i in. 2016].

Zależność tę potwierdzają badania wykonane przez Nelsona i in. [2013]. W tym eksperymencie wykorzystano próbki wody zawierające czystą hodowlę Escherichia coli $\mathrm{i}$ takie, które pochodziły z oczyszczalni ścieków miasta Regina - były to ścieki trzeciorzędowe. W miejscu ich użycia poddano je działaniu diod emitujących ultrafioletowe światło o długości fali $265 \mathrm{~nm}$. Okazało się, że bakterie inaktywują się pod wpływem światła, ale w zależności od czasu ekspozycji (redukcja nastąpiła odpowiednio po 20 i po 50 minutach). Promienie UV były mniej skuteczne w przypadku wody pochodzącej ze ścieków, ze względu na wyższy poziom zmętnienia [Nelson i in. 2013].

Badania nad optymalizacją technologiczną diod emitujących światło ultrafioletowe, wykorzystywanych do uzdatniania wody pitnej, trwają. Obecnie nie jest to jeszcze metoda, która mogłaby zastąpić inne z powodu małej wydajności, jednak wyniki eksperymentów jasno pokazują, że dezynfekowanie wody przy użyciu promieniowania jest możliwe. Inwestycja w ulepszanie diod LED wydaje się być zatem opłacalna - taka technologia byłaby tańsza i łatwiejsza w użyciu [Yumu Lui i in. 2016]. 


\section{Podsumowanie}

Zarówno naturalne promieniowanie słoneczne, jak i sztuczne źródła światła, o różnym natężeniu i różnej długości fal, mają znaczący wpływ na mikroorganizmy różnych gatunków. Obecnie stosowane technologie pozwalają na wykorzystanie zróżnicowanych źródeł światła sztucznego, takich jak lampy fluorescencyjne, plazmowe czy neonowe, a także diod elektroluminescencyjnych (LED), które wyróżniają się łatwością kontrolowania długości fali, poprzez zmianę barwy światła. Poprzez odpowiedni dobór długości fal świetlnych ludzie mogą zwiększyć lub przyspieszyć produkcję związków niezbędnych w przemyśle spożywczym, kosmetycznym, chemicznym czy medycznym. Tego typu działanie występuje zwykle w przypadku organizmów autotroficznych, które do odżywiania potrzebują właśnie światła oraz dwutlenku węgla.

Światło może też wpływać na mikroorganizmy negatywnie, hamując ich rozwój i zabijając je. Dlatego można je wykorzystywać w leczeniu chorób dermatologicznych lub jako czynnik dezynfekujący skórę, powierzchnie, a nawet wodę.

Dzięki światłu możliwe jest oczyszczanie produktów spożywczych bez użycia odkażających czy konserwujących substancji chemicznych, które mogą wpływać negatywnie na zdrowie konsumentów. Fototerapia może też zapobiegać zakażeniom - działanie bakteriobójcze światła w wielu przypadkach może sprawić, że rany będą się szybciej i lepiej goić. Analizując wyniki powyższych badań, można liczyć, że wykorzystanie diod ledowych będzie się dynamicznie rozwijać i przyniesie ludzkości wiele korzyści. Dlatego istnieje potrzeba prowadzenia badań naukowych, aby wykorzystać te możliwości w pełni.

\section{Bibliografia}

Chae-Hun R., Chang-Han K., Jang-Hyun J., Gwi-Taek J., Sung-Koo K., 2016. Effects of light-emitting diodes (LEDs) on the accumulation of lipid content using a two-phase culture process with three microalgae. Bio. Tech. 212, 254-261; https://doi.org/10.1016/j.biortech.2016.04.059.

Chin-Hang S., Tseng K., Jaiswal R., 2017. Effects of light intensity and wavelength on the production of lactobionic acid from whey by Pseudomonas taetrolens in batch cultures, 2017. Chem. Tech. Biotech. 93(6), 1595-1600; https://doi.org/10.1002/jctb.5528.

EMIS Proffesional, 2018. https://www-1 emis-1com-1qzu6li0s0a23.han.bg.up.lublin.pl $/ \mathrm{php} / \mathrm{search} /$ doc?dcid=636114341\&ebsco=1? [dostęp 23.03.2020]

Farrell H., Hayes J., Laffey J., Rowan N., 2010. Studies on the relationship between pulsed UV light irradiation and the simultaneous occurrence of molecular and cellular damage in clinically-relevant Candida albicans. J. Microbiol. Methods 84(2), 317-326; https://doi.org/10.1016/j.mimet.2010.12.021.

Fiutak G., Filipczak-Fiutak M., Surówka K., 2018. Wpływ światła LED o różnej charakterystyce spektralnej na cechy jakościowe liofilizowanego jarmużu. Inż. Przetw. Spoż. 2(26), 10-14.

Jarvis P., Autin O., Goslan E., Hassard F., 2019. Application of Ultraviolet Light-Emitting Diodes (UV-LED) to Full-Scale Drinking-Water Disinfection. Water 11, 1894; doi:10.3390/w11091894.

Jung-Hun K., Young-Ah J., Si-Bum S., Sun Ah J., Soon Ho H., Jae Kwang S., Gyeong Tae E., 2020. Wysokopoziomowa produkcja i wysokowydajny odzysk kwasu laktobionowego poprzez kontrole $\mathrm{pH}$ i temperatury w fermentacji Pseudomonas taetrolens. Bioproc. Biosyst. Eng.; https://doi.org/10.1007/s00449-020-02290-z. 
Łuczycka D., Zygmunt G., 2012. Wpływ światła LED na wzrost pieprzycy siewnej (Lepidium sativum). Inż. Rol., 5(2) (137), 177-183.

McGinley K.J., Leyden J.J., Marples R.R., Path M.R.C., Kligman A.M., 1975. Quantitative microbiology of the scalp in non-dandruff, dandruff, and seborrheic dermatitis. J. Invest. Dermatol., 64(6), 401-405.

Matthew A., Downing W., Blunt T., 1878. Researches on the effect of light upon Bacteria and other organisms. Royal Soc. Publ. 26, 179-184; https://doi.org/10.1098/rspl.1877.0068. J. Invest. Dermatol. 64(6), 401-405; https://doi.org/10.1111/1523-1747.ep12512335.

Metsoviti M., Papapolymerou G., Karapanagiotidis I., Katsoulas N., 2020. Effect of Light Intensity and Quality on Growth Rate and Composition of Chlorella vulgaris. Plants 9(1): 31; https://doi.org/10.3390/plants9010031.

Nelson K., McMartin D., Yost C., Runtz K., Ono T., 2013. Point-of-use water disinfection using UV light-emitting diodes to reduce bacterial contamination. Environ. Sci. Pollut. Res. 20, 8, 5441-5448, DOI 10.1007/s11356-013-1564-6.

PWN, 1997-2020. Światło. Encyklopedia Państwowego Wydawnictwa Naukowego, https://encyklopedia.pwn.pl/haslo/swiatlo; 3984392.html [dostęp: 23.03.2020].

Ruey B., Yu R., Van Scott E., 2009. Clinical and cosmeceutical uses of hydroxyacids. Clinics Dermatol. 27(5), 495-501; https://doi.org/10.1016/j.clindermatol.2009.06.023

Saarela M., Hallamaa K., Mattila-Sandholm T., Mättö J., 2003. The effect of lactose derivatives lactulose, lactitol and lactobionic acid on the functional and technological properties of potentially probiotic Lactobacillus strains. Inter. Dairy J. 13, 4, 2003, 291-302; https://doi.org/10.1016/S0958-6946(02)00158-9.

Seung Wi H., Young Na E., JungYun S., Lee J., 2012. The antifungal effect of light emitting diode on Malassezia yeasts. J. Dermatol. Sci. 67, 1, 3-8, https://doi.org/10.1016/j.jdermsci.2012.04.001.

Warner R., Schwartz J., Boissy Y., Dawson T., 2001. Dandruff has an altered stratum corneum ultrastructure that is improved with zinc pyrithione shampoo. J. Amer. Acad. Dermatol. 45(6), 897-903, https://doi.org/10.1067/mjd.2001.117849.

Weichenthal M., Schwarz T., 2005. Phototherapy: How does UV work? Photoderm., Photoimmunol. Photomed. 21(5), 260-266; DOI: 10.1111/j.1600-0781.2005.00173.x.

Yumu Lui G., Roser D., Corkish R., Ashbolt N., Stuetz R., 2016. Point-of-use water disinfection using ultraviolet and visible light-emitting diodes. Sci. Total. Environment. 553, 626-635, https://doi.org/10.1016/j.scitotenv.2016.02.039. 


\section{Martyna Kasela ${ }^{1,3}$, Agnieszka Grzegorczyk ${ }^{1}$, Mateusz Ossowski ${ }^{2}$, Bożena Nowakowicz-Dębek ${ }^{2}$, Anna Malm ${ }^{1}$}

\section{Personel domu pomocy spolecznej jako rezerwuar metycylinoopornych szczepów Staphylococcus sureus}

Nursing home personnel as a reservoir of methicillin-resistant strains of Staphylococcus aureus

Staphylococcus aureus może kolonizować skórę i błony śluzowe człowieka, lecz w sprzyjających dla niego warunkach, tj. stany obniżonej odporności czy naruszenie powłok skórnych, wywołuje zakażenia. Pomimo że kolonizacja przebiega zazwyczaj bezobjawowo, ludzie będący nosicielami S. aureus przyczyniają się do rozpowszechnienia tego patogenu w środowisku, co może zagrażać osobom z czynnikami predysponującymi do zakażeń $S$. aureus [Carter i in. 2002]. Ze względu na ograniczone możliwości terapeutyczne, szczepy MRSA (metycylinooporne szczepy Staphylococcus aureus) wymieniane są przez wielu autorów jako jedne z ważnych współczesnych patogenów bakteryjnych [CDC 2019, Yu i in. 2020]. Według Europejskiego Centrum ds. Zapobiegania i Kontroli Chorób, w 2018 r. w Polsce $15,9 \%$ zakażeń inwazyjnych o etiologii $S$. aureus było spowodowanych przez szczepy MRSA, a 17,4\% z nich dotyczyło osób powyżej 65 roku życia [ECDC 2019]. Oprócz osób skolonizowanych, rezerwuarem szczepów MRSA w środowisku pozaszpitalnym mogą być także zwierzęta oraz skażone przedmioty i powierzchnie [Nowakowicz-Dębek i in. 2016]. Pracownicy służby zdrowia narażeni są na ciągły kontakt $\mathrm{z}$ materiałem biologicznym potencjalnie zakaźnym zarówno przez kontakt z osobami zakażonymi, jak i zanieczyszczonymi powierzchniami. Domy Pomocy Społecznej (DPS) dla osób w podeszłym wieku stanowią środowisko, w którym personel ma bliski kontakt z rezydentami - osobami chorymi, z osłabionym układem immunologicznym, często hospitalizowanymi, co może sprzyjać transmisji $S$. aureus i stwarzać ryzyko infekcji endogennej. Co więcej, specyfika środowiska pracy pracowników służby zdrowia wiąże się ze zwiększoną ekspozycją osób na szczepy MRSA [Cimolai 2008, Haamann i in. 2011].

\footnotetext{
${ }^{1}$ Uniwersytet Medyczny w Lublinie, Wydział Farmaceutyczny, Katedra i Zakład Mikrobiologii Farmaceutycznej

${ }^{2}$ Uniwersytet Przyrodniczy w Lublinie, Wydział Nauk o Zwierzętach i Biogospodarki, Katedra Higieny Zwierząt i Zagrożeń Środowiska

3 e-mail: kasela.martyna@gmail.com
} 
Celem badań była ocena częstości kolonizacji S. aureus (w tym szczepów MRSA) w górnych drogach oddechowych personelu DPS w Lublinie w okresie roku, przy jednoczesnym uwzględnieniu charakteru pracy badanych osób.

\section{Badania wlasne}

Badaniem objęto 37 pracowników DPS w Lublinie: 30 kobiet $(81,1 \%)$ oraz 7 mężczyzn $(18,9 \%)$ w wieku od 26 do 67 lat (śr. $42,7 \pm 9,1)$. Pracowników podzielono na trzy grupy wyróżnione ze względu na rodzaj kontaktu z rezydentami (tab. 1). Od uczestników badania pobierano wymazy z przedsionków nosa oraz gardła za pomocą jałowych, bawełnianych wymazówek czterokrotnie: w styczniu, kwietniu, lipcu oraz październiku 2018 r. Bezpośrednio przed pobraniem wymazów, wymazówki (Medlab, Polska) zwilżano jałowym roztworem $(0,9 \%)$ soli fizjologicznej (POCH, Polska). Wymazówkę wkładano na głębokość ok. $2 \mathrm{~cm}$ do lewego otworu nosowego i obracano przez co najmniej 3 sekundy. Tą samą wymazówką pobierano wymaz z prawego otworu nosowego. Wymazy z gardła pobierano, wymazując tylną ścianę gardła, unikając dotykania wymazówką jamy

Tabela 1. Charakterystyka badanych grup pracowników Domu Pomocy Społecznej

\begin{tabular}{|c|c|c|c|c|}
\hline $\begin{array}{l}\mathrm{Nr} \\
\text { grupy }\end{array}$ & $\begin{array}{l}\text { Kontakt } \\
\text { z rezydentami }\end{array}$ & Zawód & $\begin{array}{l}\text { Liczba } \\
\text { osób }\end{array}$ & Charakterystyka pracy \\
\hline \multirow{3}{*}{$\begin{array}{l}\mathrm{I} \\
(n=13)\end{array}$} & \multirow{3}{*}{$\begin{array}{l}\text { bliski } \\
\text { i bezpośredni }\end{array}$} & pielęgniarki & 5 & $\begin{array}{l}\text { podawanie leków, wykonywanie } \\
\text { procedur medycznych, pomoc } \\
\text { w żywieniu i utrzymywaniu higieny } \\
\text { osób niesamodzielnych }\end{array}$ \\
\hline & & opiekunowie & 5 & $\begin{array}{l}\text { dbanie o zdrowie i higienę osobistą } \\
\text { osób chorych i niesamodzielnych, } \\
\text { aktywizacja i rehabilitacja rezydentów }\end{array}$ \\
\hline & & fizjoterapeuci & 3 & $\begin{array}{l}\text { planowanie oraz prowadzenie fizjo- } \\
\text { terapii i masażu }\end{array}$ \\
\hline \multirow{3}{*}{$\begin{array}{l}\text { II } \\
(n=5)\end{array}$} & \multirow{3}{*}{$\begin{array}{l}\text { umiarkowany } \\
\text { bezpośredni } \\
\text { kontakt } \\
\text { lub częsty } \\
\text { kontakt pośredni }\end{array}$} & $\begin{array}{l}\text { terapeuci } \\
\text { zajęciowi }\end{array}$ & 5 & $\begin{array}{l}\text { usprawnianie fizyczne oraz psy- } \\
\text { chiczne poprzez zastosowanie zajęć } \\
\text { typu manualnego, intelektualnego } \\
\text { i rozrywkowego }\end{array}$ \\
\hline & & $\begin{array}{l}\text { personel } \\
\text { sprzątający }\end{array}$ & 7 & $\begin{array}{l}\text { utrzymanie czystości w budynku, } \\
\text { w tym pokojów i toalet rezydentów } \\
\text { oraz przestrzeni wspólnej }\end{array}$ \\
\hline & & $\begin{array}{l}\text { pracownicy } \\
\text { pralni }\end{array}$ & 2 & $\begin{array}{l}\text { sortowanie i pranie odzieży, pościeli } \\
\text { oraz ręczników }\end{array}$ \\
\hline \multirow{3}{*}{$\begin{array}{l}\text { III } \\
(n=9)\end{array}$} & \multirow{3}{*}{$\begin{array}{l}\text { brak kontaktu } \\
\text { lub bardzo } \\
\text { rzadki kontakt } \\
\text { bezpośredni } \\
\text { i pośredni }\end{array}$} & $\begin{array}{l}\text { pracownicy } \\
\text { administracyjni }\end{array}$ & 7 & $\begin{array}{l}\text { czynności zapewniające koordynację } \\
\text { działań dps }\end{array}$ \\
\hline & & $\begin{array}{l}\text { pracownicy } \\
\text { kuchni }\end{array}$ & 1 & przygotowywanie posiłków \\
\hline & & $\begin{array}{l}\text { administrator } \\
\text { budynku }\end{array}$ & 1 & $\begin{array}{l}\text { utrzymanie dobrego stanu technicz- } \\
\text { nego budynku }\end{array}$ \\
\hline
\end{tabular}


ustnej. W razie konieczności stosowano jałowe, drewniane szpatułki laryngologiczne (Polmil, Polska). Następnie, materiał transportowano do Katedry i Zakładu Mikrobiologii Farmaceutycznej Uniwersytetu Medycznego w Lublinie i posiewano na agar tryptozowo-sojowy $\mathrm{z}$ dodatkiem 5\% krwi baraniej (BioRad, USA) oraz na podłoże Chapmana (Biomaxima, Polska). Podłoża inkubowano w warunkach tlenowych w temperaturze $35^{\circ} \mathrm{C}$ przez $24-48 \mathrm{~h}$. Identyfikację gatunkową prowadzono z użyciem analizatora bakteriologicznego Vitek 2 Compact oraz kart GP (BioMerieux, Francja). Komisja Bioetyczna przy Uniwersytecie Medycznym w Lublinie wyraziła zgodę na przeprowadzenie badań (KE 0254/59/2016). Przed przystąpieniem do badania, uczestnicy podpisywali świadomą zgodę na udział $\mathrm{w}$ badaniu.

Szczepy MRSA wykrywano metodą dyfuzyjno-krążkową z wykorzystaniem cefoksytyny (30 $\mu \mathrm{g}$; Beckton Dickinson, USA) zgodnie z rekomendacjami Europejskiego Komitetu ds. Oznaczania Lekowrażliwości EUCAST. Metycylionooporność potwierdzano genetycznie wykrywając gen mecA. Wykorzystane sekwencje starterów przedstawia tabela 2.

Tabela 2. Charakterystyka starterów zastosowanych przy detekcji genu mecA [Ryffel i in. 1990]

\begin{tabular}{|l|c|c|c|}
\hline $\begin{array}{c}\text { Nazwa } \\
\text { starterów }\end{array}$ & Sekwencja nukleotydowa (5'-3') & $\begin{array}{c}\text { Długość starterów } \\
(\mathrm{pz})\end{array}$ & $\begin{array}{c}\text { Długość produktu } \\
(\mathrm{pz})\end{array}$ \\
\hline$m e c A-F$ & ACTGCTATCCACCCTCAAAC & 20 & 163 \\
\hline$m e c A-R$ & CTGGTGAAGTTGTAATCTGG & 20 & \\
\hline
\end{tabular}

Objaśnienia: pz - par zasad

Materiał genetyczny izolowano za pomocą zestawu do izolacji bakteryjnego, genomowego DNA Genomic Mini AX Bacteria Spin (A\&A Biotechnology, Polska). Pojedynczą kolonią testowanego izolatu $\mathrm{S}$. aureus zaszczepiano $3 \mathrm{ml}$ bulionu tryptozowo-sojowego (BTL, Polska) i inkubowano przez 18-24 h w temperaturze $35^{\circ} \mathrm{C}$. Następnie $1 \mathrm{ml}$ płynnej hodowli przenoszono do jałowej probówki o pojemności 1,5 ml (Eppendorf, Niemcy) i wirowano przez 10 minut przy $7500 \mathrm{rpm}$ (Eppendorf Mini Spin, Niemcy). Supernatant usuwano, a osad bakteryjny zawieszano w $100 \mu \mathrm{l}$ buforu do zawieszania. Po dodaniu $10 \mu 1$ lizostafiny (A\&A Biotechnology, Polska), próbki inkubowano $\mathrm{w} 37^{\circ} \mathrm{C}$ przez 10 minut (Biometra TS1 ThermoShaker, Niemcy). W celu oczyszczenia z białek, próbki inkubowano z dodatkiem $400 \mu \mathrm{l}$ buforu lizującego i $20 \mu \mathrm{l}$ proteinazy $\mathrm{K}$ w temperaturze $50^{\circ} \mathrm{C}$ przez 15 minut $\mathrm{z}$ wytrząsaniem przy $1400 \mathrm{rpm}$. Próbki nanoszono na kolumienki i wirowano $(15 \mathrm{~s}$, $8000 \mathrm{rpm}$ ); płyn odrzucano, a kolumienkę umieszczano w nowej probówce. Kolumienki dwukrotnie wirowano z roztworami płuczącymi w objętości $600 \mu 1$ i $500 \mu \mathrm{l}(45 \mathrm{~s}, 8000 \mathrm{rpm})$. Następnie kolumienki umieszczano w nowej probówce typu Eppendorf i przeprowadzano elucję DNA ze złoża przez dwukrotne na- 
niesienie $75 \mu 1$ buforu elucyjnego i wirowanie $(60 \mathrm{~s}, 8000 \mathrm{rpm})$. Wyizolowany materiał genetyczny przechowywano $\mathrm{w}$ temperaturze $4^{\circ} \mathrm{C}$ do dalszych analiz.

Reakcje PCR prowadzono w objętości $15 \mu \mathrm{l}$. W skład mieszaniny reakcyjnej wchodziło: 7,5 $\mu 1$ RedTaq Readymix PCR Reaction Mix (Sigma-Aldrich, USA), po $1 \mu \mathrm{l}$ ze starterów, $4,5 \mu \mathrm{l}$ wody do PCR oraz $1 \mu \mathrm{l}$ badanej matrycy DNA. Zastosowano następujące warunki amplifikacji dla genu mecA: denaturacja wstępna $\mathrm{w} 94^{\circ} \mathrm{C}$ przez 5 minut, 25 cykli denaturacji właściwej w $94^{\circ} \mathrm{C}$ przez 2 minuty, przyłączania starterów w $52^{\circ} \mathrm{C}$ przez 2 minuty i elongacji w $72^{\circ} \mathrm{C}$ przez 2 minuty, a następnie elongacji końcowej w $72^{\circ} \mathrm{C}$ przez 7 minut (Biometra, Niemcy). Produkty rozdzielano w 1,5\% żelu agarozowym z dodatkiem $4 \mu \mathrm{l}$ barwnika SimplySafe (EurX, Polska) razem z markerem wielkości 100-1000 par zasad (Thermo Fisher Scientific, USA) przez 30 minut pod napięciem $120 \mathrm{~V}$ (Biometra, Niemcy). Żel umieszczano w transiluminatorze, fotografowano, analizowano (Vilber-Lourmat, Francja) i archiwizowano.

W badaniu wyróżniono nosicielstwo stałe i przejściowe. Za osoby będące stałymi nosicielami $S$. aureus w górnych drogach oddechowych uznano pracowników, u których $S$. aureus został wyizolowany z przedsionków nosa i/lub gardła co najmniej trzykrotnie w ciągu okresu trwania badania. Zarówno odsetek nosicieli stałych, jak i przejściowych we wszystkich badanych grupach był zbliżony (tab. 3); wśród wszystkich pracowników wynosił odpowiednio 40,5\% i 43,2\%. Brak kolonizacji w całym czasie trwania badania stwierdzono najczęściej u pracowników z grupy I $(23,1 \%)$. Kolonizacji nie stwierdzono tylko u $16,2 \%$ pracowników DPS.

Tabela 3. Częstość występowania nosicielstwa Staphylococcus aureus u pracowników Domu Pomocy Społecznej

\begin{tabular}{|l|c|c|c|}
\hline \multirow{2}{*}{$\begin{array}{c}\text { Grupa } \\
\text { pracowników }\end{array}$} & \multicolumn{3}{|c|}{ Liczba (odsetek) osób } \\
\cline { 2 - 4 } & nosicielstwo stałe & $\begin{array}{c}\text { nosicielstwo } \\
\text { przejściowe }\end{array}$ & brak kolonizacji \\
\hline I & $5(38,5)$ & $5(38,5)$ & $3(23,1)$ \\
II & $6(40)$ & $7(46,7)$ & $2(13,3)$ \\
III & $4(44,4)$ & $4(44,4)$ & $1(11,1)$ \\
Razem & $15(40,5)$ & $16(43,2)$ & $6(16,2)$ \\
\hline
\end{tabular}

Udział procentowy nosicieli $S$. aureus w różnych porach roku przedstawiono w tabeli 4. Najwyższą częstość kolonizacji $S$. aureus dla grupy I i II zanotowano w lipcu $(61,5 \%$ i $60 \%)$, natomiast dla grupy III w październiku (55,6\%). Dla wszystkich grup najniższy odsetek nosicielstwa zaobserwowano w styczniu i mieścił się w zakresie od 38,5\% dla grupy I do 46,7\% dla grupy II. 
Tabela 4. Częstość kolonizacji górnych dróg oddechowych przez Staphylococcus aureus u pracowników domu pomocy społecznej w zależności od pory roku

\begin{tabular}{|l|c|c|c|c|}
\hline \multirow{2}{*}{$\begin{array}{c}\text { Grupa } \\
\text { pracowników }\end{array}$} & \multicolumn{4}{|c|}{ Liczba (odsetek) osób } \\
\cline { 2 - 5 } & $\begin{array}{c}\text { zima } \\
\text { (styczeń) }\end{array}$ & $\begin{array}{c}\text { wiosna } \\
\text { (kwiecień) }\end{array}$ & $\begin{array}{c}\text { lato } \\
\text { (lipiec) }\end{array}$ & $\begin{array}{c}\text { jesień } \\
\text { (październik) }\end{array}$ \\
\hline I & $5(38,5)$ & $6(46,2)$ & $8(61,5)$ & $6(46,2)$ \\
II & $7(46,7)$ & $7(46,7)$ & $9(60)$ & $8(53,3)$ \\
III & $4(44,4)$ & $4(44,4)$ & $4(44,4)$ & $5(55,6)$ \\
Razem & $16(43,2)$ & $17(45,9)$ & $21(56,8)$ & $19(51,4)$ \\
\hline
\end{tabular}

Niemal co piąty pracownik DPS był co najmniej jednokrotnie skolonizowany przez MRSA w ciągu czasu trwania badania (ryc. 1). Obecność nosicieli MRSA zanotowano zarówno w grupie I, jak i II, i stanowili oni kolejno 23,1\% i 26,7\% pracowników. Szczepów MRSA nie wyizolowano tylko w grupie III, wśród pracowników niemających kontaktów z rezydentami DPS. Analiza genetyczna potwierdziła obecność genu mecA wszystkich 15 izolatów MRSA wyizolowanych od 7 pracowników. Ponad połowę $(53,4 \%)$ szczepów MRSA wyizolowano w okresie letnim. Obecności MRSA w górnych drogach oddechowych personelu DPS nie zanotowano tylko w okresie zimowym (ryc. 2).

Istnieje wiele badań uwzględniających częstość kolonizacji MRSA u rezydentów DPS, jednak niewiele $\mathrm{z}$ nich obejmuje długoterminowe dochodzenia epidemiologiczne dotyczące personelu, a co za tym idzie, umożliwiające rozpoznanie stałego bądź przejściowego typu nosicielstwa. Odsetek pracowników DPS skolonizowanych przez MRSA różni się znacząco w zależności od wielkości ośrodka i kraju badania. W krajach europejskich waha się od kilku do kilkunastu procent [March i in. 2010, Gruber i in. 2013, Peters i in. 2017, Sassmannshaussen $i$ in. 2016]. Równie często pomijana jest rola pracowników DPS reprezentujących zawody niemedyczne w transmisji $S$. aureus, np. personelu sprzątającego czy terapeutów zajęciowych, mających w codziennej pracy bliski kontakt

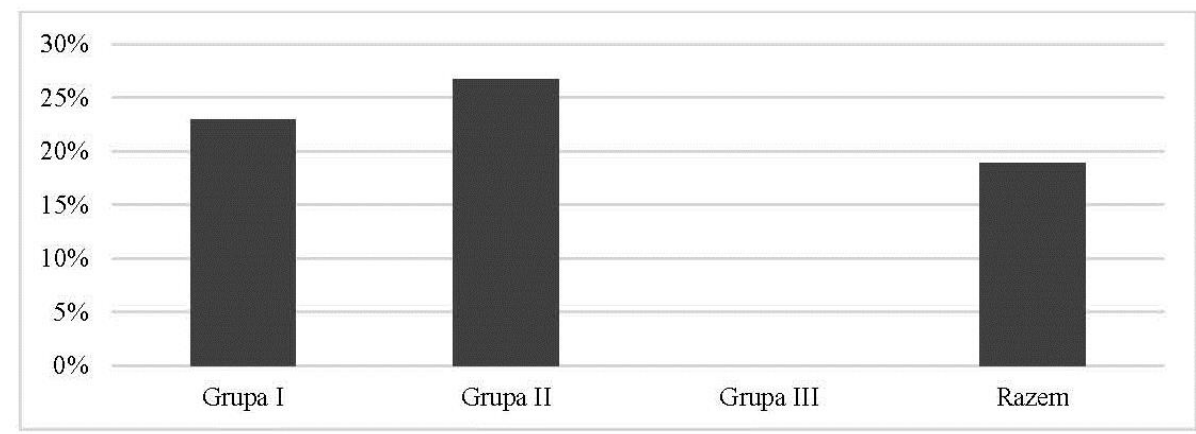

Ryc. 1. Częstość izolacji MRSA w zależności od grupy pracowników Domu Pomocy Społecznej $(n=37)$ 


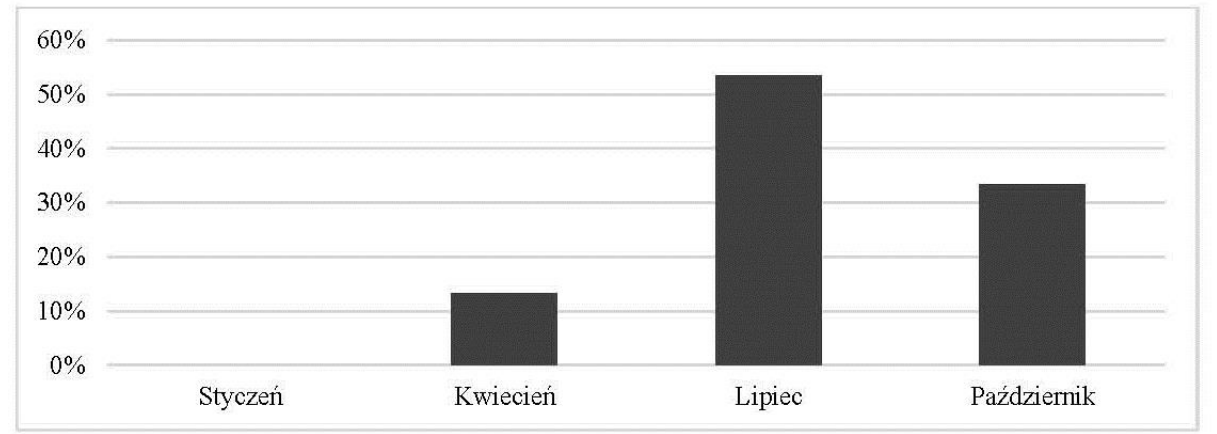

Ryc. 2. Częstość izolacji MRSA w zależności od pory roku (n=15)

z rezydentami lub powierzchniami potencjalnie zanieczyszczonymi przez MRSA. Badania skupiające się na roli środowiska w cyrkulacji szczepów MRSA podkreślają znaczenie kontaminacji przedmiotów codziennego użytku w transmisji tych patogenów. Badanie przeprowadzone przez Murphy i in. [2012] ujawniło, że aż $16 \%$ analizowanych obiektów, tj. sprzęt rehabilitacyjny, stoły, krzesła, poręcze czy klamki, było zanieczyszczonych przez MRSA. Wektorem MRSA mogą być także telefony komórkowe personelu medycznego [Pal i in. 2015]. Chociaż do podstawowych środków ochronny indywidualnej personelu medycznego limitujących transmisję MRSA na terenie DPS należą jednorazowe rękawiczki oraz fartuchy ochronne, trzeba pamiętać, że niewłaściwe ich stosowanie, np. brak zmiany rękawiczek między pacjentami może intensyfikować cyrkulację MRSA. Oprócz transmisji MRSA drogą bezpośredniego kontaktu z nosicielem, bardzo istotną rolę ogrywa kontaminacja środowiska, dlatego personel sprzątający wydaje się być szczególnie narażony na MRSA w środowisku pracy ze względu na codzienne wykonywanie takich czynności jak zmiana pościeli czy mycie podłóg i toalet w pokojach rezydentów [Albrecht $i$ in. 2017]. Dodatkowo, analiza czynników ryzyka u pracowników DPS przeprowadzona przez Sassmannshausen i in. [2016] ujawniła, że osoby o znanej historii kolonizacji przez MRSA oraz cierpiące na trądzik były znacznie częściej nosicielami szczepów MRSA.

W badaniach własnych, miesiącem o najwyższej częstości kolonizacji pracowników DPS przez S. aureus był lipiec. Również Jiménez-Truque i in. [2014] zaobserwował najwyższą częstość kolonizacji u sportowców w lecie. Podobne tendencje obserwowane są także w badaniach analizujących częstość występowania zakażeń o etiologii $S$. aureus. Jest ona największa w porach roku o najwyższych temperaturach i wilgotności - $w$ sezonie letnim $i$ jesiennym [Mermel i in. 2011]. Na częstość kolonizacji mogą wpływać warunki atmosferyczne. W badaniach Blanco i in. [2017] zaobserwowano dodatnią korelację między poziomem wilgotności względnej powietrza, średnią miesięczną temperaturą i sumą opadów atmosferycznych a częstością kolonizacji przez MRSA u pacjentów przyjmowanych do szpitali na terenie USA. 
Oprócz potencjalnego zagrożenia dla osób starszych płynącego z obecności nosicieli MRSA wśród personelu DPS, należy także pamiętać o konsekwencjach dotyczących zdrowia pracowników wynikających ze zwiększonego narażenia na czynniki zakaźne w środowisku pracy. Chociaż wśród 389 roszczeń prawnych o orzeczenie infekcji o etiologii MRSA jako choroby zawodowej u pracowników służby zdrowia w Niemczech, tylko 17 uznano za uzasadnione, to aż $60 \% \mathrm{z}$ nich zadeklarowało obecność bliskiego kontaktu z pacjentami, w tym z pacjentami zainfekowanymi MRSA. Osoby te pracowały jako pielęgniarki w szpitalach lub jako pielęgniarki geriatryczne [Haamann i in. 2011].

\section{Podsumowanie i wnioski}

Obecność szczepów MRSA wśród pracowników świadczy o ich udziale w krążeniu tych patogenów w środowisku DPS i zwiększa prawdopodobieństwo wystąpienia zakażeń o etiologii MRSA. Szczepy MRSA zostały wyizolowane także u osób mających w pracy bezpośredni kontakt z osobami starszymi, niebędącymi personelem medycznym, co świadczy o konieczności uwzględnienia, np. personelu sprzątającego $\mathrm{w}$ trakcie badań mających na celu okresową kontrolę nosicielstwa MRSA. Zmienna częstość izolacji $S$. aureus z górnych dróg oddechowych pracowników w różnych porach roku podkreśla potrzebę regularnego (co najmniej dwukrotnie w ciągu roku) monitoringu częstości kolonizacji w badaniach epidemiologicznych.

Wśród najważniejszych wniosków wynikających z badań własnych należy wymienić następujące:

1. Odsetek nosicieli stałych i przejściowych $S$. aureus wśród pracowników DPS wynosił odpowiednio 40,5\% i 43,2\%.

2. Najwyższą częstość kolonizacji górnych dróg oddechowych pracowników DPS zanotowano w okresie letnim, zarówno przez S. aureus, jak i szczepy MRSA.

3. Szczepy MRSA wyizolowano tylko w grupach pracowników mających bliski bezpośredni lub pośredni kontakt z rezydentami DPS (gr. I i II).

4. Niemal co piąty pracownik DPS $(18,9 \%)$ był co najmniej jednokrotnie skolonizowany przez MRSA w trakcie trwania badania.

\section{Bibliografia}

Albrecht J.S., Croft L., Morgan D.J., Roghmann M.C., 2016. Perceptions of gown and glove use to prevent methicillin-resistant Staphylococcus aureus transmission in nursing homes. J. Am. Med. Dir. Assoc. 18(2), 158-161, https://doi.org/10.1016/j.jamda.2016.08.016.

Blanco N., Perencevich E., Li S.S., Morgan D.J., Pineles L., Johnson J.K., Robinson G, Anderson D.J., Jacob J.T., Maragakis L.L., Harris, A.D., 2017. Effect of meteorological factors and geographic location on methicillin-resistant Staphylococcus aureus and vancomycin-resistant enterococci colonization in the US. PloS one 12(5), e0178254, https://doi.org/10.1371/journal.pone.0178254. 
Carter A., Heffernan H., Holland D., Ikram R., Morris A., Roberts S., Roberts A., Boyd J., 2002. Guidelines for the control of methicillin-resistant Staphylococcus aureus in New Zealand. Wellington, New Zealand, http://www.moh.govt.nz/cd/mrsa [dostęp: 27.02.2020].

CDC, 2018. Antibiotic resistance threats in the United States. Antimicrobial Resistance. Centers for Disease Control and Prevention, https://www.cdc.gov/drugresistance/pdf/threatsreport/2019-ar-threats-report-508.pdf [dostęp: 27.02.2020].

Cimolai N., 2008. The role of healthcare personnel in the maintenance and spread of methicillinresistant Staphylococcus aureus. J. Infect. Public Heal. 1(2), 78-100, https://doi.org/10.1016/j.jiph.2008.10.001.

ECDC, 2019. Surveillance atlas of infectious diseases. European Centre for Disease Prevention and Control, https://atlas.ecdc.europa.eu/public/index.aspx [dostęp: 27.02.2020].

Gruber I., Heudorf U., Werner G., Pfeifer Y., Imirzalioglu C., Ackermann H., Brandt C., Besier S., Wichelhaus T.A., 2013. Multidrug-resistant bacteria in geriatric clinics, nursing homes, and ambulant care-prevalence and risk factors. Int. J. Med. Microbiol. 303(8), 405-409, http://doi.org/10.1016/j.ijmm.2013.05.002.

Haamann F., Dulon M., Nienhaus A., 2011. MRSA as an occupational disease: a case series. Int Arch. Occup. Environ. Health 84(3), 259-266, https://doi.org/10.1007/s00420-010-0610-7.

Jiménez-Truque N., Saye E.J., Soper N., Saville B.R., Thomsen I., Edwards K.M., Creech C.B., 2016. Longitudinal assessment of colonization with Staphylococcus aureus in healthy collegiate athletes. J. Pediat. Inf. Dis. Soc. 5(2), 105-113, https://doi.org/10.1093/jpids/piu108.

March A., Aschbacher R., Dhanji H., Livermore D.M., Böttcher A., Sleghel F., Maggi S., Noale M., Larcher C., Woodford N., 2010. Colonization of residents and staff of a long-term-care facility and adjacent acute-care hospital geriatric unit by multiresistant bacteria. Clin. Microbiol. Infec. 16(7), 934-944, https://doi.org/10.1111/j.1469-0691.2009.03024.x.

Mermel L.A., Machan J.T., Parenteau S., 2011. Seasonality of MRSA infections. PloS one 6(3), e17925, https://doi.org/10.1371/journal.pone.0017925.

Murphy C.R., Eells S.J., Quan V., Kim D., Peterson E., Miller L.G., Huang S.S., 2012. Methicillin resistant Staphylococcus aureus burden in nursing homes associated with environmental contamination of common areas. J. Am. Geriatr. Soc. 60(6), 1012-1018, https://doi.org/10.1111/j.1532-5415.2012.03978.x.

Nowakowicz-Dębek B., Wlazło Ł., Kasela M., Ossowski M., 2016. Epidemiologia wielolekoopornych szczepów Staphylococcus aureus. Probl. Hig. Epidemiol. 97(2), 106-112.

Pal S., Juyal D., Adekhandi S., Sharma M., Prakash R., Sharma N., Parihar A., 2015. Mobile phones: reservoirs for the transmission of nosocomial pathogens. Adv. Biomed. Res. 4, 144-149, https://doi.org/10.4103/2277-9175.161553.

Peters C., Dulon M., Kleinmüller O., Nienhaus A., Schablon A., 2017. MRSA prevalence and risk factors among health personnel and residents in nursing homes in Hamburg, Germany - a crosssectional study. PLoS one 12(1), e0169425, https://doi.org/ 10.1371/journal.pone.0169425.

Ryffel C., Tesch W., Birch-Machin I., Reynolds P.E., Barberis-Maino L., 1990. Sequence comparison of mecA genes isolated from methicillin-resistant Staphylococcus aureus and Staphylococcus epidermidis. Gene 94(1), 137-138, https://doi.org/10.1016/0378-1119(90)90481-6.

Sassmannshausen R., Deurenberg R.H., Köck R., Hendrix R., Jurke A., Rossen J.W., Friedrich A.W., 2016. MRSA prevalence and associated risk factors among health-care workers in non-outbreak situations in the Dutch-German EUREGIO. Front. Microbiol. 7, 1273, https://doi.org/10.3389/fmicb.2016.01273.

Yu Z., Tang J., Khare T., Kumar V., 2019. The alarming antimicrobial resistance in ESKAPEE pathogens: Can essential oils come to the rescue? Fitoterapia 140, 104433, https://doi.org/10.1016/j.fitote.2019.104433. 
Katarzyna Karpińska ${ }^{1,4}$, Damian Jaguszewski ${ }^{1}$, Mateusz Ossowski ${ }^{2}$, Martyna Kasela ${ }^{3}$, Bożena Nowakowicz-Dębek ${ }^{2}$

\section{Skuteczność dezynfekcji telefonów komórkowych z wykorzystaniem komercyjnych chusteczek antybakteryjnych}

The effectiveness of disinfecting mobile phones with the use of commercial antibacterial wipes

Smartfon stał się przedmiotem prawie niezbędnym w codziennym życiu i jednocześnie nieodłącznym atrybutem człowieka XXI w. Smartfony są obecne w życiu każdego człowieka. Używamy ich praktycznie wszędzie, a także w różnych warunkach atmosferycznych - w domu, w pracy, na dworze, latem, podczas mrozów, w łazience czy też w kuchni. To sprzyja rozwojowi bakterii i wirusów, które w większości przypadków nie są korzystne dla naszego zdrowia. Telefon może być wektorem rozprzestrzeniania się drobnoustrojów, w tym także chorobotwórczych [Krajewska-Kułak i in. 2010]. Poprzez bezpośredni kontakt ze skórą i wilgotną dłonią, telefony mogą odgrywać znaczącą rolę w procesie transmisji drobnoustrojów w społeczeństwie, a co za tym idzie powodować różnorakie choroby, których przyczyny nie będziemy się w stanie domyślić. Dlatego powinniśmy powierzchnię naszych telefonów poddawać dezynfekcji. Do tego celu mogą posłużyć powszechnie dostępne na rynku chusteczki nasączone środkiem antybakteryjnym.

\section{Dezynfekcja}

Dezynfekcja, według encyklopedii PWN, to niszczenie w określonym środowisku zewnętrznym drobnoustrojów chorobotwórczych i ich form przetrwalnikowych, mające na celu zapobieganie zakażeniom. Do dezynfekcji stosuje się środki fizyczne, takie jak wysoka temperatura, promieniowanie słoneczne, nadfioletowe lub chemiczne, czyli odpowiednie preparaty z substancją aktywną. Rozróżnia się dezynfekcję zapobiegawczą i ogniskową, którą przeprowadza się w bezpośrednim otoczeniu chorego. Szczególnym rodzajem dezynfekcji jest wyjaławianie [http://encyklopedia.pwn.pl].

\footnotetext{
${ }^{1}$ SKN Nauk o Zwierzętach i Biogospodarki - Sekcja Higieny Pracy

${ }^{2}$ Katedra Higieny Zwierząt i Zagrożeń Środowiska, Wydział Nauk o Zwierzętach i Biogospodarki, Uniwersytet Przyrodniczy w Lublinie

${ }^{3}$ Katedra i Zakład Mikrobiologii Farmaceutycznej, Wydział Farmaceutyczny, Uniwersytet Medyczny w Lublinie

${ }^{4}$ e-mail: katarzyna1297@gmail.com
} 
Przeprowadzanie dezynfekcji ma na celu redukcję liczebności mikroorganizmów obecnych w środowisku, w którym jest zastosowana. Dezynfekcja jest odpowiedzialna za niszczenie form wegetatywnych mikroorganizmów, lecz nie zawsze usuwa ich formy przetrwalnikowe. Dezynfekcja w odróżnieniu od antyseptyki, dotyczy przedmiotów i powierzchni użytkowych, które po przeprowadzeniu tej operacji nie muszą być jałowe.

Dezynfekcję można przeprowadzić, korzystając z dostępnych preparatów chemicznych lub metod fizycznych, a połączenie tych metod nazywamy procesem chemiczno-termicznym (podwyższona temperatura przyspiesza proces zachodzących reakcji), [Buchrieser i Miorini 2009].

Stosowane do dezynfekcji preparaty podzielić można na wyroby lub produkty biobójcze. Większą część rynku zdominowały preparaty biobójcze. Przynależność do konkretnej grupy specyfików określają ustawy o produktach biobójczych [Dz.U. 2015, poz. 1926], oraz o wyrobach medycznych [Dz.U. $2010 \mathrm{nr} 107$ poz. 679] wraz z Obwieszczeniem Marszałka Sejmu RP w sprawie ogłoszenia jednolitego tekstu ustawy o wyrobach medycznych [Dz.U. 2015 poz. 876]. Aby produkt mógł trafić do nabywcy, musi spełnić pewne wytyczne zawarte w aktach prawnych.

Skuteczność działania preparatu oraz jego przeznaczenie musi być potwierdzone badaniami, zgodnymi z metodami Państwowego Zakładu Higieny (PZH). Rejestrację produktów biobójczych można przeprowadzić na dwa sposoby: w procedurze narodowej lub w procedurze europejskiej. Wybór właściwej metody zależy od statusu substancji czynnej. Przedsiębiorstwo jest zobowiązane do rejestracji produktu w procedurze europejskiej, jeśli substancja jest zatwierdzona. Natomiast jeśli jeszcze podlega ocenie, wówczas należy zastosować rejestrację w procedurze narodowej. Status substancji czynnych, jest na bieżąco aktualizowany na stronie Europejskiej Agencji Chemikaliów[Dz.U. 2015, poz. 1926, Röhm-Rodowald i in. 2008].

Substancje pochodzenia chemicznego służące do dezynfekcji w różny sposób działają na drobnoustroje. Powinno się dostrzegać różnicę pomiędzy działaniem bójczym, które wywołuje nieodwracalne zmiany w komórkach, a działem bakteriostatycznym, ograniczającym namnażanie drobnoustrojów mogących doprowadzić do zakażenia. Złe określenie działania preparatu może stworzyć sytuację, w której zastosowany zostanie środek o niewłaściwych parametrach, tj. stężenie, czas działania. Taka sytuacja może w konsekwencji doprowadzić do wyodrębnienia szczepów odpornych na środki dezynfekcyjne [Röhm-Rodowald i in. 2008].

Technika zastosowana $\mathrm{w}$ procesie dezynfekcji wynika $\mathrm{z}$ rodzaju materiału, jaki ma zostać zdezynfekowany. Stosowane techniki dezynfekcji:

-zanurzanie w środku dezynfekcyjnym (technika stosowana np. przy dezynfekcji narzędzi medycznych).

- przecieranie (technika polegająca na zwilżaniu powierzchni, np. blatów kuchennych),

- wcieranie (technika stosowana np. przy dezynfekcji rąk),

- dezynfekcja aerozolowa (stosowana np. w chłodniach) [Buchrieser i Miorini 2009]. 


\section{Substancje wykorzystywane w procesie dezynfekcji}

Przy dezynfekcji wykorzystuje się wiele związków, które w istotny sposób zwalczają zagrażające człowiekowi bakterie, wirusy i grzyby. Do grona związków wykorzystywanych w tym procesie należą: związki fenolowe, związki chloru, aldehydy, związki nadtlenowe, alkohole, czwartorzędowe związki amoniowe (powierzchniowo czynne).

Związki fenolowe charakteryzują się aktywnością bakteriobójczą, przeciwprątkową, grzybobójczą oraz wirusobójczą (do pewnego zakresu). Nie posiadają jednak aktywności sporobójczej. Preparatów opierających się na tych związkach nie powinno stosować się do odkażania skóry, sprzętu mającego kontakt ze skórą oraz do powierzchni, które mają kontakt $\mathrm{z}$ artykułami spożywczymi, ponieważ związki te są toksyczne, a ich biodegradowalność jest niska. [Fleischar 2009, Röhm-Rodowald i in. 2009, Głuszek 2010].

Związki chloru nawet w niewielkim stężeniu wykazują działanie bójcze wobec wegetatywnych form bakterii, mykoplazm, wirusów i grzybów. Przy stężeniu wyższym pozbawiają aktywności Mycobacterium tuberculosis (1000 ppm) i przetrwalniki Clostridium difficile (5000 ppm). Związków chloru nie powinno stosować się na materiały z tworzyw sztucznych, gumowe oraz metalowe. Kontakt chloru z tymi materiałami powoduje ich degradację lub korozję [Fleischar 2009, Röhm-Rodowald i in. 2009, Głuszek 2010].

Aldehydy w niższych stężeniach używane są do dezynfekcji natomiast $\mathrm{w}$ większych procesie sterylizacji. Aldehydy charakteryzują się pełnym spektrum biobójczym. Są toksyczne, oddziaływają drażniąco, a także mutagennie. Aldehydami wykorzystywanymi w dezynfekcji są: aldehyd mrówkowy, który posiada właściwości bakteriobójcze, wirusobójcze, grzybobójcze i sporobójcze, oraz aldehyd glutarowy, który wykorzystywany jest dezynfekcji sprzętów medycznych ze względu na pełne spektrum działania [Fleischar 2009, Röhm-Rodowald i in. 2009, Głuszek 2010].

Związki nadtlenowe wykazują wysoką zdolność dezaktywacji zarówno form wegetatywnych, jak i przetrwalników. Jedną z ich najważniejszych cech jest niska toksyczność oraz wysoki stopień biodegradacji. Po zastosowaniu drobnoustroje nie nabierają na te związki odporności. Niestety przyśpieszają korozję powierzchni metalowych [Fleischar 2009, Röhm-Rodowald i in. 2009, Głuszek 2010].

Alkohole używane są do antyseptyki skóry oraz dezynfekcji powierzchni. Najczęściej wykorzystywanymi alkoholami są alkohol etylowy i izopropylowy. Charakteryzują się one szybką aktywnością bakteriobójczą oraz posiadają szeroki zakres działania. Wartym odnotowania jest fakt, że alkohol etylowy traci swoją bakteriobójczość po rozcieńczeniu wodą. Roztwór $60 \%$ tego alkoholu nie wykazuje właściwości biobójczych [Fleischar 2009, Röhm-Rodowald i in. 2009, Głuszek 2010].

Czwartorzędowe związki amoniowe (powierzchniowo czynne) wykazują aktywność biobójczą wobec bakterii, grzybów oraz wirusów lipofilnych. Charakte- 
ryzują się również brakiem aktywności dla spor bakteryjnych i prątków. Do grupy tych związków należą: chlorek alkilobenzylowy, chlorek alkilodimetylobenzyloaminowy oraz bromek didecyldimetylamoniowy [Fleischar 2009, Röhm-Rodowald i in. 2009, Głuszek 2010].

Działanie substancji antybakteryjnych zależy od wielu czynników. Należą do nich: temperatura, wilgotność, $\mathrm{pH}$ oraz czas działania i stężenie preparatu. Aktywność niektórych związków chemicznych na poszczególne grupy organizmów przedstawia tabela 1. Najwyższą aktywność zarówno na bakterie, jak i grzyby wykazują aldehydy oraz związki utleniające. Przy wyborze preparatu należy więc zwrócić uwagę nie tylko na warunki wykorzystania, ale i substancje czynną.

Tabela 1. Aktywność wybranych związków chemicznych na poszczególne grupy mikroorganizmów [oprac. na podstawie http://biotechnologia.pl]

\begin{tabular}{|l|c|c|c|c|}
\hline \multirow{2}{*}{ Związki chemiczne } & \multicolumn{2}{|c|}{ Aktywność } & \multicolumn{2}{c|}{} \\
\cline { 2 - 5 } & $\begin{array}{c}\text { bakterie } \\
\text { Gram-dodatnie }\end{array}$ & $\begin{array}{c}\text { bakterie } \\
\text { Gram-ujemne }\end{array}$ & grzyby & $\begin{array}{c}\text { ogólna } \\
\text { aktywność }\end{array}$ \\
\hline Alkohole & + & + & $+/-$ & średnia \\
Aldehydy & + & + & + & wysoka \\
Związki chloru & + & + & $+/-$ & wysoka \\
Związki utleniające & + & + & + & wysoka \\
Powierzchniowo czynne & + & + & + & średnia \\
\hline
\end{tabular}

Objaśnienia:+ działanie bójcze, - brak działania bójczego, +/- bardzo słabe działanie lub jego brak

\section{Higiena rąk}

Higiena rąk to główny czynnik wpływający na ograniczanie rozprzestrzeniania się zakażeń. Ręce przez wzgląd na liczbę przedmiotów, które dotykamy w ciągu dnia, są w dużym stopniu narażone na gromadzenie się na nich drobnoustrojów. Na skórze każdego człowieka znajduje się wiele różnorodnych gatunków drobnoustrojów. Na skład jakościowy i ilościowy mikroflory wpływają takie czynniki jak: temperatura, $\mathrm{pH}$, wilgotność, potencjał oksydoredukcyjny, wiek, stan odporności organizmu, nawyki żywieniowe i higieniczne oraz terapia lekami przeciwdrobnoustrojowymi [Kampf i Kramer 2004].

Większość z nich wchodzi w skład mikroflory fizjologicznej, do której należeć mogą zarówno drobnoustroje komensalne, jak i drobnoustroje potencjalnie chorobotwórcze.

Obok mikroflory fizjologicznej można wyróżnić mikroflorę przejściową. Wśród niej można wymienić: bakterie, wirusy i grzyby, które przez krótki czas mogą znajdować się na rękach, ale nie wchodzą w skład naturalnej mikroflory. Mogą się rozmnażać, ale są szybko usuwane przez mikroflorę fizjologiczną [Samaranayake i Jones 2004, Dzierżanowska-Fangrat i in. 2010]. 


\section{Cel pracy}

Celem naszej pracy było sprawdzenie chusteczek antybakteryjnych pod kątem skuteczności dezynfekcji powierzchni telefonów komórkowych. Wiele badań naukowych dowodzi, że ekrany dotykowe telefonów komórkowych są doskonałymi przykładami miejsc, z którymi mamy ciągły kontakt, a o których czyszczeniu zapominamy. W konsekwencji stają się źródłem wielu drobnoustrojów.

\section{Badania własne}

Do realizacji nakreślonego celu pracy, zakupiono dostępne na rynku chusteczki antybakteryjne. Poniżej zamieszczono krótki opis wybranych produktów:

- Ch1 chusteczki antybakteryjne - $0 \%$ alkoholu. W ich składzie m.in. Aqua, MethylPropanediol, Coco-Glucoside, Allantoin, Phenoxyethanol, Ethylhexylglycerin, Sodium Benzoate, Cetylpiridinium Chloride, Cetrimonium Chloride, Sodium Lactate, LacticAcid, Parfum, Butylphenyl, Methylpropional, Benzyl Salicylate, HexylCinnamal;

- Ch2 chusteczki antybakteryjne. Główny skład: Aqua, Etyl alcohol, Glycerin, Disodium Cocoamphodiacetate, Phenoxyethanol, Chamomilla Recutita Extract, Banzalkonium;

- Ch3 chusteczki antybakteryjne, zawierające m.in.: Aqua, Alcohol Denat., Propylene Glycol, Cetylpyridinium Chloride, Tetrasodium Glutamate Diacetate, CitricAcid, Parfum, Phenoxyethanol, Ethylhexylglycerin, Sodium Benzoate;

- Ch4 chusteczki antybakteryjne do urządzeń, zawierające m.in.: Aqua, Ethanol, Methylisothiazolinone, Butylcarbamate, Parfum, Cocamidopropylamineoxide;

- Ch5 chusteczki antybakteryjne, zawierające m.in.: Cotton, Alcohol Denat., Aqua, Propylene Glycol, DMDM Hydantoin, PEG-40 Hydrogenated, Triethanolamine, Benzyl Alcohol, Benzyl Salicylate, Hydroxycitronellal;

- Ch6 chusteczki z płynem antybakteryjnym, zawierające w składzie głównie: Alcohol Denat., Diglycerin, Tetrasodium Glutamate Diacetate, Potassium Sorbate, Sodium Benzoate, Phenoxyethanol, Citric Acid, Cetylpyridinum Chloride, Linalool, Hexyl Cinnamal, Benzyl Salicytate, Buthylphenyl Methylpropional.

Badania przeprowadzono na 12 telefonach. Telefony komórkowe podzielono na dwie grupy liczące po 6 telefonów komórkowych: grupa doświadczalna telefony były czyszczone (dezynfekowane z wykorzystaniem chusteczek); grupa kontrolna - telefony nieczyszczone (niedezynfekowane chusteczkami).

Badania mikrobiologiczne zarówno przed, jak i po zastosowaniu chusteczek przeprowadzono metodą odciskową na następujących podłożach:

- agar wzbogacony (BioMaxima SA) - podłoże uniwersalne do hodowli, namnażania, oznaczania ogólnej liczby mikroorganizmów; 
- Sabourauda (BioMaxima SA) - podłoże stosowane do hodowli jakościowej dermatofitów i innych grzybów patogennych oraz niepatogennych z próbek klinicznych oraz nieklinicznych.

Po inkubacji wyrosłe kolonie zliczono, a wyniki przedstawiono w postaci koncentracji bakterii tlenowych mezofilnych, ogólnej liczby bakterii oraz grzybów przypadających na jeden telefon. Otrzymane wyniki zostały przedstawione jako jednostki tworzące kolonie, wyliczono wskaźnik redukcji zamieszczono w tabeli i na wykresie.

\section{Wyniki i ich analiza}

Uzyskane wyniki zamieszczono w tabelach 2,3 i 4, a także na rycinie 1 . Koncentrację bakterii tlenowych mezofilnych, wyrażoną w jednostkach tworzących kolonie (jtk) oraz procent redukcji przedstawiono w tabeli 2.

Tabela 2. Koncentracja bakterii tlenowych mezofilnych na powierzchni telefonów (jtk/telefon)

\begin{tabular}{|l|c|c|c|}
\hline \multicolumn{1}{|c|}{ Nr próby } & Kontrolna & Doświadczalna & \% redukcji \\
\hline Ch1 & $1,2 \times 10^{2}$ & $5,3 \times 10^{1}$ & 56,56 \\
Ch2 & $2,1 \times 10^{2}$ & $7,6 \times 10^{1}$ & 63,81 \\
Ch3 & $1,5 \times 10^{2}$ & $7,3 \times 10^{1}$ & 77,0 \\
Ch4 & $4,9 \times 10^{1}$ & $0,4 \times 10^{1}$ & 91,84 \\
Ch5 & niepoliczalne & $6,7 \times 10^{1}$ & - \\
Ch6 & $1,8 \times 10^{2}$ & $2,7 \times 10^{1}$ & 84,57 \\
Średnio & $1,4 \times 10^{2}$ & $5,0 \times 10^{1}$ & 74,195 \\
\hline
\end{tabular}

Zarówno w grupie kontrolnej, jak i doświadczalnej otrzymano najniższą liczebność bakterii tlenowych mezofilnych przy zastosowaniu chusteczek - Ch4, odpowiednio $4,9 \times 10^{1}$ jtk i $0,4 \times 10^{1}$ jtk. Przy zastosowanie tych chusteczek odsetek redukcji okazał się największy, bo niemal 92\%. Natomiast najniższą redukcję otrzymano dla chusteczek Ch1 - niecałe 57\%. Uśredniona wartość skuteczności dezynfekcji dla wszystkich wykorzystanych doświadczeniu chusteczek wynosiła około $74 \%$.

Na rycinie 1 przedstawiono uzyskane wyniki ogólnej liczbę bakterii. Literą $\mathrm{K}$ i kolorem niebieskim oznaczono grupę kontrolną, a literą $\mathrm{D}$ i kolorem czerwonym grupę doświadczalną.

W grupie doświadczalnej $\mathrm{w}$ stosunku do grupy kontrolnej, zanotowano zmniejszenie ogólnej liczby bakterii na telefonie (ryc. 1). Wyjątek stanowi pozycja oznaczona jako Ch5. W tym przypadku zanotowano wzrost liczebności bakterii po zastosowaniu chusteczek antybakteryjnych. Tłumaczyć to można tym, że drobnoustroje nie zostały wyeliminowane, a tylko rozprzestrzenione z zakamarków na całą powierzchnię ekranu telefonów komórkowych. Ogólną liczbę bakterii oraz odsetek redukcji przedstawia tabela 3 . 


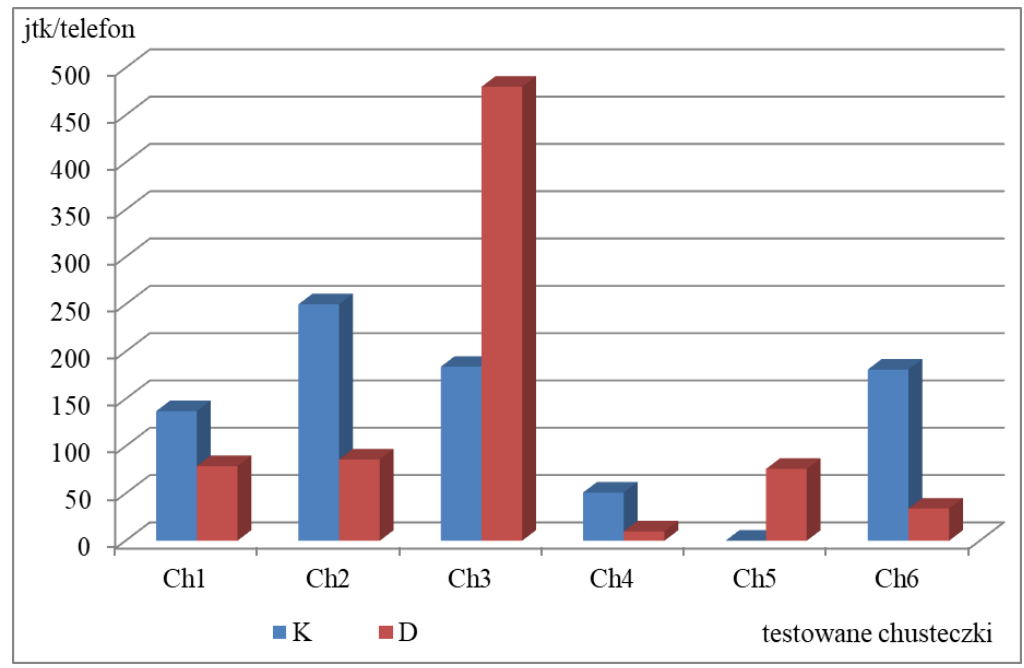

Ryc. 1. Liczebność bakterii na powierzchni telefonów (jtk/telefon)

Tabela 3. Ogólna liczba bakterii na powierzchni telefonów (jtk/telefon)

\begin{tabular}{|l|c|c|c|}
\hline \multicolumn{1}{|c|}{ Nr próby } & Kontrolna & Doświadczalna & \% redukcji \\
\hline Ch1 & $1,4 \times 10^{2}$ & $7,9 \times 10^{1}$ & 42,34 \\
Ch2 & $2,5 \times 10^{2}$ & $8,6 \times 10^{1}$ & 65,60 \\
Ch3 & $1,8 \times 10^{2}$ & $4,8 \times 10^{1}$ & + \\
Ch4 & $5,1 \times 10^{1}$ & $1,0 \times 10^{1}$ & 80,39 \\
Ch5 & niepoliczalne & $7,6 \times 10^{1}$ & - \\
Ch6 & $1,8 \times 10^{2}$ & $3,4 \times 10^{1}$ & 81,22 \\
Średnio & $1,6 \times 10^{2}$ & $1,3 \times 10^{1}$ & 67,39 \\
\hline
\end{tabular}

Najwyższą skuteczność redukcji dla ogólnej liczby bakterii uzyskano dla chusteczek Ch6. Zastosowanie chusteczek $\mathrm{Ch} 5$ dało również wysoki procent redukcji $(80,39)$. W próbie Ch5 w grupie kontrolnej liczebność bakterii była niepoliczalna, dlatego też procent redukcji był niemożliwy do obliczenia.

Zaobserwowano, że zastosowanie chusteczek Ch3 spowodowało wzrost ogólnej liczby bakterii. Średni wskaźnik redukcji dla tego parametru wynosi $67,39 \%$.

W tabeli 4 zamieszczono wyniki badań ogólnej liczba grzybów występujących na badanych telefonach oraz procent ich redukcji.

Koncentracja grzybów na powierzchni telefonów w grupie kontrolnej wahała się. Otrzymane wyniki dla telefonów grupy kontrolnej mieszczą się w przedziale od $0,2 \times 10^{1}$ do $1,0 \times 10^{1} \mathrm{jtk}$. W grupie doświadczalnej (po dezynfekcji) wyniki mieszczą się w zakresie od 0 do $0,4 \times 10^{1} \mathrm{jtk}$, co jak widać w tabeli pozwoliło na $100 \%$ redukcji przy zastosowaniu chusteczek Ch3. Natomiast najmniejszą redukcję w zakresie liczebności grzybów otrzymano dla chusteczek $\mathrm{Ch} 2$ i Ch4 i wynosił on 50\%. Średni procent redukcji dla wszystkich chusteczek wynosi $66,95 \%$. 
Tabela 4. Ogólna liczba grzybów na powierzchni badanych telefonów (jtk/telefon)

\begin{tabular}{|l|c|c|c|}
\hline \multicolumn{1}{|c|}{ Nr próby } & Kontrolna & Doświadczalna & \% redukcji \\
\hline Ch1 & $1,0 \times 10^{1}$ & $0,4 \times 10^{1}$ & 60 \\
Ch2 & $0,4 \times 10^{1}$ & $0,2 \times 10^{1}$ & 50 \\
Ch3 & $0,2 \times 10^{1}$ & 0 & 100 \\
Ch4 & $0,2 \times 10^{1}$ & $0,1 \times 10^{1}$ & 50 \\
Ch5 & $0,4 \times 10^{1}$ & $0,1 \times 10^{1}$ & 75 \\
Ch6 & $0,3 \times 10^{1}$ & $0,1 \times 10^{1}$ & 66,67 \\
Średnio & $0,4 \times 10^{1}$ & $0,2 \times 10^{1}$ & 66,95 \\
\hline
\end{tabular}

Przeprowadzone badania przez innych Autorów wskazują również, że telefony komórkowe są rezerwuarem drobnoustrojów [Nowakowicz-Dębek i in. 2013, Sriram i in. 2018]. Nowakowicz-Dębek i in. [2013] na telefonach identyfikowali najczęściej grzyby z rodzaju Penicillium sp., Aspergillus sp., Ulocladium sp., Trichoderma spp., zaś dominujące bakterie to głównie: Corynebacterium, Micrococcus, Kocuria, Staphylococcus, Streptococcus i Staphylococcus aureus. Autorzy do dezynfekcji telefonów wykorzystali ozon i promieniowanie UV. Badania potwierdziły działanie bakteriobójcze i grzybobójcze obu metod dezynfekcji. Współczynnik redukcji (LRF) dla ogólnej liczby bakterii i grzybów wykazał wyższą skuteczność ozonu 4,2 $\mathrm{mg} \mathrm{O}_{3} / \mathrm{h}$. Natomiast Sriram i in. [2018] przeprowadzili badania telefonów komórkowych pozyskanych od stomatologów, którzy z racji wykonywanego zawodu są narażeni na liczne patogeny. Do odkażania telefonów wykorzystano alkohol izopropylowy i promieniowanie ultrafioletowe(UV). Po oczyszczeniu telefonów obydwoma metodami zaobserwowano statystycznie istotne spadek średniej liczby kolonii, co wskazuje, że oba środki były skuteczne w dezynfekcji. Szczegółowa analiza, wykazała wyższą skuteczność dezynfekcji przy zastosowaniu alkoholu izopropylowego w porównaniu z UV.

Podsumowując, można stwierdzić, że telefony komórkowe są rezerwuarem mikroorganizmów i należy je regularnie poddawać dezynfekcji.

\section{Podsumowanie i wnioski}

Telefon komórkowy (smartfon) może być wektorem mikroorganizmów na swojej powierzchni. Używanie chusteczek antybakteryjnych może poprawiać ich stan sanitarny.

1. W trakcie przeprowadzonych badań najwyższą redukcję bakterii tlenowych mezofilnych uzyskano przy zastosowaniu chusteczek Ch4 $(91,84 \%)$.

2. Najwyższą redukcję ogólnej liczby bakterii uzyskano przy zastosowaniu chusteczek Ch6 $(81,22 \%)$.

3. Najwyższą redukcję ogólnej liczby grzybów uzyskano dla chusteczek Ch3. 


\section{Bibliografia}

Bio-Tech Media, 2010. Związki chemiczne stosowane w dezynfekcji, http://www.biotechnologia.pl/kosmetologia/artykuly/zwiazki-chemiczne-stosowane-w-dezynfekcji,10523 [dostęp: 17.01.2020 r.].

Buchrieser V., Miorini T., 2009. Grundlagen der Reinigung, Desinfektion und Sterilisation. WFHSS.

Dzierżanowska-Fagrant K., Pawińska A., Semczuk K., 2010. Higiena rąk i otoczenia Polaków. Centrum Zdrowia Dziecka. Warszawa

Fleischar M., 2009. Dezynfekcja, sterylizacja, antyseptyka., Uniw. Medyczny im. Piastów Śląskich we Wrocławiu.

Głuszek K., 2010. Ocena wrażliwości szczepów Staphylococcus aureus na środki dezynfekcyjne. Studia Med., 19, 13-23.

http://www.encyklopedia.pwn.pl/haslo/dezynfekcja;3892269.html [dostęp: 20.01.2020r.]

Kampf G., Kramer A., 2004. Podstawy epidemiologiczne higieny rąk wraz z oceną najważniejszych środków myjących i dezynfekcyjnych. Prace Przegl. z Zakresu Mikrobiologii Klinicznej $17,4,863-893$.

Krajewska-Kułak E., Kułak W., Łukaszuk C., van Damme-Ostapowicz K., Lewko J., Rozwadowska E., Guzowski A., 2010. Rola telefonu komórkowego w transmisji drobnoustrojów. Medical Mycol. 17, 3, 182-185. 4p.

Nowakowicz-Dębek B., Wlazło Ł., Krukowski H., Pawlak H., Trawińska B., 2013. Reduction of microbial contamination of mobile phones using ultraviolet UV radiation and ozone. African J. Microbiol. Res. 7(49), 5541-5545.

Obwieszczenie Marszałka Sejmu Rzeczypospolitej Polskiej z dnia 26 maja 2015 r. w sprawie ogłoszenia jednolitego tekstu ustawy o wyrobach medycznych (Dz.U. 2015 poz. 876).

Röhm-Rodowald E., Jakimiak B., Chojecka A., Podgórska M., 2009. Biobójcze substancje czynne w preparatach dezynfekcyjnych. Zakażenia $5,10-16$.

Röhm-Rodowald E., Jakimiak B., Podgórska M., 2008. Zasady rejestrowania, opiniowania i badania preparatów dezynfekcyjnych. Przegl. Epidemiol. 62, 661-688.

Samaranayake L.P., Jones B.M., 2004. Podstawy mikrobiologii dla stomatologów, PZWL.

Sriram S., Madan Kumar P.D., Swaminathan R., Venkatesh R., Menaka V., 2018. Effectiveness of isopropyl alcohol and ultraviolet-based sanitiser on decontamination of mobile phones used by dental personnel. J. Patient Safety Infect. Control 6(1), 19-22.

Ustawa z dnia 20 maja 2010 r. o wyrobach medycznych (Dz.U. $2010 \mathrm{nr} 107$ poz. 679)

Ustawa z dnia 9 października 2015 r. o produktach biobójczych (Dz.U. 2015 poz. 1926). 
Anita Gorczyca $^{1}$, Antonina Krawczyk ${ }^{1,2}$

\section{Charakterystyka SARS-COV-2 na tle pozostałych koronawirusów}

Characteristics of SARS-CoV-2 compared to other coronaviruses

Na przełomie 2019/2020 r. wybuchła trzecia pandemia wywołana przez koronawirusy. Rozpoczęła się ona $\mathrm{w}$ chińskim mieście Wuhan i rozprzestrzeniała się na całym świecie. W obecnej chwili (09.09.2020 r.) jest to 189 krajów (ryc. 1), które toczą walkę z SARS-CoV-2 wywołującym chorobę COVID-19. Przebieg choroby COVID-19 zależy od stanu zdrowia i wieku chorego. Najbardziej narażonymi na zakażenie są osoby w podeszłym wieku oraz mające współistniejące schorzenia przewlekłe [Pradhan i in. 2020]. Dotychczas nie uważano tych wirusów za groźne, ponieważ powodowały lekkie zapalenia górnych dróg oddechowych, dopiero po pierwszej epidemii SARS, która wybuchła w 2002 r., również w Chinach, zaczęto bliżej przyglądać się rodzinie koronawirusów [Wu i in. 2020].

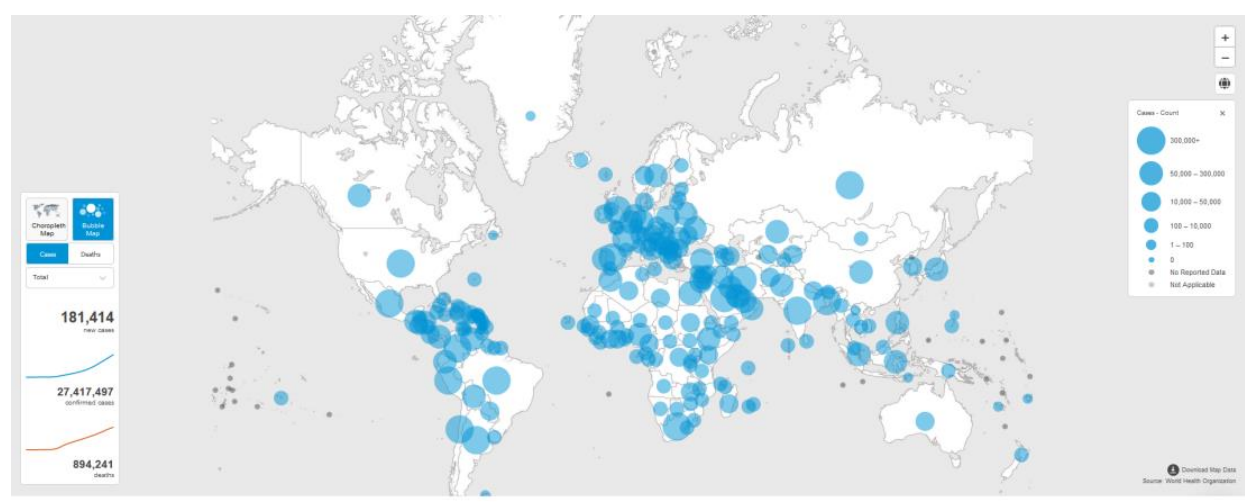

Ryc. 1. Lokalizacja ognisk COVID-19, Światowej Organizacji Zdrowia (https://covid19.who.int/)

\footnotetext{
${ }^{1}$ Koło Naukowe Studentów Bioinżynierii i Biotechnologii BioGen, Wydział Agrobioinżynierii, Instytut Genetyki, Hodowli i Biotechnologii Roślin, Uniwersytet Przyrodniczy w Lublinie

2 e-mail: tosiakr@gmail.com
} 


\section{Epidemie koronawirusów}

Epidemia SARS. W 2002 r. wybuchła pierwsza epidemia SARS-CoV. SARS to skrót pochodzący od Severe Acute Respiratory Syndrome, tzn. zespół ciężkiej ostrej niewydolności oddechowej [Meo i in. 2020]. Dopiero w marcu 2003 r. WHO poinformowało służby medyczne na całym świecie o ryzyku epidemii. Wprowadzono obowiązkowe badania ochronne i profilaktyczne u podróżujących do krajów azjatyckich oraz objęto kwarantanną potencjalnie chorych. Szybko zauważono, że choroba przenosi się drogą kropelkową, a ludzie, podróżując i przemieszczając się, zarażają się wzajemnie [Severe Acute Respiratory Syndrome, dostęp: 26.04.2012]. Ważną rolę $\mathrm{w}$ przenoszeniu się SARS-CoV odegrały dwie mutacje wirusowe: K479N, S487T. Zwiększyły one powinowactwo domeny S1-CTD w glikoproteinie S do ludzkiego enzymu konwertującego angiotensynę 2 (ACE2) [Fang 2016]. Na SARS zachorowało około 8000 osób na całym świecie [WHO 2012]

Epidemia MERS. W 2012 r. wybuchła kolejna pandemia spowodowana przez koronawirusy, czyli MERS, który swoje pierwsze ognisko miał w Arabii Saudyjskiej, a następnie przeniósł się do innych krajów Bliskiego Wschodu, m.in. do Kataru. Bliskowschodni zespół niewydolności oddechowej, czyli Middle East Respiratory Syndrome, jest chorobą zakaźną o wysokiej śmiertelności sięgającej ok. 36\%, wywoływaną przez koronawirusa MERS-CoV. Jest to wirus zoontyczny. Źródłem zakażenia są wielbłądy jednogarbne. Zakażenie obejmowało bezpośredni kontakt ze zwierzęciem bądź ich wydalinami i wydzielinami, jak również spożywanie zarażonego mięsa poddanego niewłaściwej obróbce termicznej [Korzeniowski 2009].

\section{Charakterystyka koronawirusów}

Koronawirusy dzielą się na cztery typy: Alphacoronavirus, Betacoronavirus, Gammacoronavirus, Deltacoronavirus (ryc. 2), [Fang 2016].

Koronawirusy to jednoniciowe wirusy o dodatniej polaryzacji kwasu nukleinowego RNA(+). Są dużymi, osłoniętymi wirusami [Fang 2016]. Ich rozmiar zawiera się w przedziale od ok. 26000 do 32000 par zasad. W obrębie genomu występuje zmienna liczba (6-11) otwartych ramek odczytu (ORF). Pierwszy ORF stanowiący około $67 \%$ całego genomu koduje 16 białek niestrukturalnych (nsps), podczas gdy pozostałe ORF kodują białka dodatkowe i białka strukturalne [Wu i in. 2020]. Białka znajdujące się na powierzchni wirusa (glikoproteina S) formują wystające kolce powierzchniowe, nadające koronawirusom charakterystyczny wygląd koron [Fang 2016].

Specyficzna struktura kapsydowa koronawirusów ułatwia im zakażanie komórek gospodarza. Zbudowane są one z 4 białek strukturalnych - S, M, E i N. Główne białka strukturalne to glikoproteina powierzchniowa (S), białko płaszcza (E), białko błonowe $(\mathrm{M})$, białko nukleokapsydu $(\mathrm{N})$. Glikoproteina S koronawi- 
rusa jest zbudowana z dwóch podjednostek - S1 i S2. Podjednostka S1 odpowiada za wiązanie receptora, natomiast S2 ułatwia fuzję błon wirusa i komórki [Fang 2016, Wu i in. 2020].

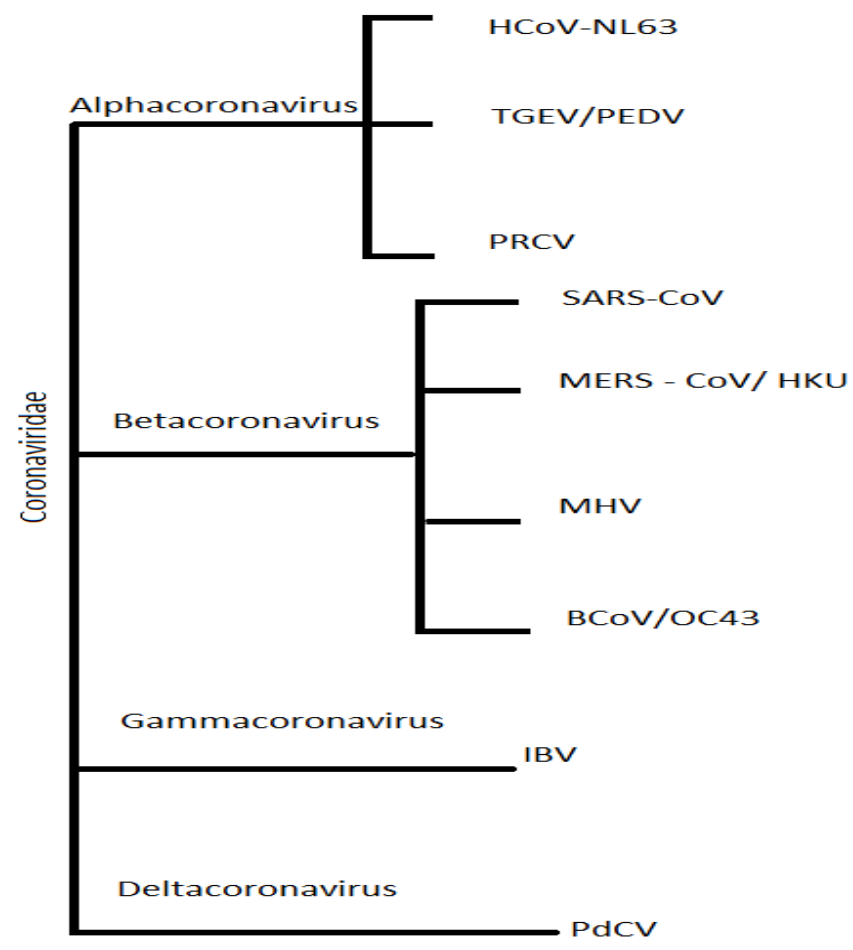

Ryc. 2. Klasyfikacja koronawirusów. Opracowanie własne

W przypadku koronawirusów, glikoproteina $\mathrm{S}$ jest przecinana na granicy między podjednostkami S1 i S2, które pozostają związane niekowalencyjnie. W dalszej części podjednostka $\mathrm{S} 1$ składa się z receptora domeny wiążącej i przyczynia się do stabilizacji białka zakotwiczonego w błonie S2 podjednostki. Glikoproteina S jest następnie rozszczepiana przez proteazy gospodarza w miejscu zlokalizowanym bezpośrednio przed peptydem fuzyjnym. W rezultacie wejście koronawirusa do podatnych komórek jest złożonym procesem, który wymaga skoordynowania wiązania receptora i proteolitycznego przetwarzania białka S w celu promowania fuzji wirus-komórka [Walls $\mathrm{i}$ in. 2020, Wu i in. 2020]. Glikoproteina $\mathrm{S}$ warunkuje tropizm do konkretnych tkanek, a także decyduje o tym, jaki organizm wirus może zainfekować [Fang 2016, Wu i in. 2020].

Białko nukleokapsydu (N) pełni dwie funkcje - chroni materiał genetyczny, aktywnie uczestniczy w modyfikacji procesów komórkowych i replikacji wirusa. Białko otoczki (E) jest odpowiedzialne za formowanie wirionów, natomiast białko błonowe $(\mathrm{M})$ jest głównym białkiem macierzy wirusa. Betakoronawirusy 
w swojej budowie mają specyficzne białko HE podobne do hemaglutyniny grypy. Białka S i HE ułatwiają adsorpcję i pomagają w przeniknięciu wirusa do komórki gospodarza. Wirusy te posiadają również białka niestrukturalne, takie jak polimeraza RNA zależna od RNA (RdRp). Miejsce aktywne enzymu RdRp jest wysoce konserwatywne i występują w nim dwie kolejne reszty asparaginianowe, dzięki czemu są one dostępnym powierzchniowym kanałem nukleotydowym, przez który przechodzić mogą nukleotydy [Fang 2016, Elfiky 2020].

Receptory gospodarza rozpoznawane przez jedną z domen glikoproteiny $\mathrm{S}-$ dokładniej S1 to: enzym konwertujący angiotensynę 2 (ACE2), aminopeptydaza $\mathrm{N}$ (APN), peptydaza dipeptydynowa 4 (DPP4), cząsteczka adhezyjna antygenu (CEACAM1) oraz cukier [Fang 2016, Wu i in. 2020]. Zidentyfikowano dwie główne domeny w koronawirusie S1: S1-NTD, S1-CTD. Domena S1-NTD jest odpowiedzialna za wiązanie cukrów, natomiast S1-CTD jest odpowiedzialna za rozpoznawanie receptorów białkowych ACE2, APN i DPP4. Domeny S1 potencjalnie wiążą receptory i funkcjonują jako domena wiążąca receptory (RBD) [Fang 2016].

Nowy koronawirus SARS-CoV-2 jest stabilny w aerozolach i na różnych powierzchniach od kilku godzin do nawet kilku dni. W przypadku otaczającego nas powietrza jest w nim wykrywalny do 3 godzin, na powierzchniach miedzianych do 4 godzin, na kartonie do 24 godzin oraz do 2 dni na powierzchniach stalowych i plastikowych [van Doremalen i in. 2020].

\section{Pochodzenie}

Analiza filogenetyczna wirusa wykazała, że SARS-CoV-2 jest w $88-89 \%$ podobny do koronawirusów bat-SL-CoVZC45 i bat-SL-CoVZXC21. Jest to większe pokrewieństwo niż z wirusem SARS-CoV, z którym ma około 79\% podobieństwa i MERS-CoV, gdzie podobieństwo wynosi ok. 50\%. Analiza RNA wirusa wyizolowanego od dwóch pacjentów z Wuhan w 2019 r. wykazała, że wirus SARS-CoV-2 jest podobny do koronawirusa występującego u nietoperza $\mathrm{z}$ gatunku podkowiec duży (Rhinolophus ferrumequinum), wykazując zgodność 98,7\% nukleotydów i 87,9\% nukleotydów w przypadku wirusów bat-SL-CoVZC45 i bat-SL-CoVZXC21. Analiza ewolucji opierająca się na ORF1a/1b genów S i N sugeruje, że SARS-CoV-2 jest najprawdopodobniej nowym koronawirusem, niezależnie przeniesionym ze zwierząt na ludzi [Chih-Cheng $\mathrm{i}$ in. 2020].

\section{Podobieństwa glikoproteiny S konoronawirusa SARS-CoV-2 i białek kodowanych przez gen gp120 wirusa HIV}

W najnowszych badaniach naukowcy z New Delhi odkryli, że w niektórych fragmentach glikoproteiny $S$ reszty aminokwasów są identyczne lub podobne do tych, które znajdują się w białkach HIV-1 gp120 i HIV-1 Gag, mimo że fragmenty te nie mają identycznej struktury pierwszorzędowej aminokwasów. Modelowanie białka w 3D pozwala zobaczyć, że fałdowanie co najmniej 3 z 4 fragmentów pro- 
wadzi do utworzenia miejsca receptorowego [Pradhan i in. 2020]. Podobne wnioski wyciągnięto podczas poprzedniej epidemii SARS-CoV. Analiza sekwencji wirusów ujawniła, że istnieją podobne motywy w białkach gp41 wirusa HIV-1 i S2 SARS-CoV odpowiedzialnych za wnikanie do komórek ludzkich. W modelowaniu 3D tych białek także wykazano podobieństwa - oba białka mają taką samą strukturę $\alpha$-helisy. Bardzo duże zbieżności w budowie białek odpowiedzialnych za fuzję z komórkami ludzkimi pozwoliły na efektowne zastosowanie preparatów stosowanych przeciwko wirusowi HIV w leczeniu zakażenia wirusem SARS-CoV. Wnioski wyciągnięte podczas poprzedniej epidemii dają nadzieję na wykorzystanie podobnej terapii w tej trwającej obecnie [Kliger i in. 2003, Shuwen i in. 2004, Zhang i in. 2014].

\section{Objawy zakażenia koronawirusem Sars-CoV-2}

Pierwsze objawy zarażenia koronawirusem SARS-CoV-2 są niemal identyczne jak w przypadku grypy. Występuje ogólne osłabienie organizmu, gorączka, kaszel, dreszcze czy ból mięśni. W obrazie $\mathrm{z}$ tomografii komputerowej widoczne są objawy zapalenia płuc z rozlanymi obustronnymi naciekami [Chih-Cheng $\mathrm{i}$ in. 2020, Elfiky 2020]. COVID-19 ma dużo cięższy przebieg niż grypa i atakuje głównie osoby starsze oraz przewlekle chore. Wirus przenosi się drogą kropelkową lub poprzez kontakt z osobą zarażoną [Paterlini 2020]. Przypuszcza się, że w przypadku wirusa SARS-CoV-2 jedna osoba może zarazić statystycznie 2,24-3,58 osoby, natomiast w przypadku grypy sezonowej jest to średnio 1,28 osoby [Biggerstaff i in. 2014, Prompetchara i in. 2020]. Dodatkowo czas inkubacji grypy wynosi 1-4 dni (średnio 1-2 dni), natomiast w przypadku COVID-19 jest to 2-14 dni [CDC 2018a, CDC 2020b]. W przypadku zakażenia SARS-CoV-2 osoby chore mogą zarażać na 24-48 godzin przed wystąpieniem objawów choroby. Ponadto u ok. $20 \%$ chorych występuje ciężki przebieg, w tym ok. 5\% potrzebuje wspomagania układu oddechowego przez respirator. Ciężki przebieg i powikłania są spowodowane wykazywaniem przez wirusa SARS-CoV-2 tropizmu nie tylko do tkanek płuc, ale także do tkanek nerek, mięśnia sercowego, gardła i przewodu pokarmowego oraz tkanki nerwowej. Uszkodzenia śródbłonka wywołane infekcją wirusową i prowadzące do powstawania stanów zapalnych mogą wywoływać nadmierną produkcję trombiny, hamować fibrynolizę i aktywować szlaki dopełniacza, inicjując zapalenie zakrzepowe i ostatecznie prowadząc do odkładania się mikrozakrzepów. Zaburze-nia mikrokrążenia połączone z zaburzeniami układu odpornościowego oraz ogólno-ustrojowym uwalnianiem cytokin mogą prowadzić do sepsy [Gupta i in. 2020].

\section{Diagnostyka koronawirusa}

Obecne wykorzystywane są dwie metody diagnostyczne COVID-19, serologiczna oraz molekularna. 
Metoda serologiczna. Metoda serologiczna oparta jest na wykrywaniu przeciwciał z klasy IgG i IgM. Metodyka opiera się na wykonywaniu testu ELISA oraz wykorzystaniu immunochromatografii (testy paskowe, kasetkowe). Testy różnią się między sobą, jednak wszystkie opierają się na tej samej zasadzie. Jest to unikatowe wiązanie się przeciwciał do konkretnych cząsteczek lub antygenów [Gołąb i in. 2006]. Testy są szybkie i tanie, niestety można ich używać tylko pomocniczo, ponieważ ich detekcja następuje dopiero po wytworzeniu przeciwciał (ok. 12 dni dla IgM oraz 14 dni dla IgG od zakażenia). Wadą tej metody są fałszywie ujemne wyniki u osób z immunosupresją, ponieważ mają one uszkodzony system wytwarzania przeciwciał odpornościowych [Zhao i in. 2020].

Pierwsze testy serologiczne, które były opracowywane na początku trwania pandemii, wykorzystujące metody immunoenzymatyczne (ELISA), neutralizacji efektu cytopatycznego w hodowli komórkowej (PRNT) oraz chemiluminescencję nie były odpowiednie do wykonywania testów przesiewowych na dużą skalę. Były bardzo czasochłonne i wymagały zaangażowania wielu pracowników laboratorium. Najczęściej wykorzystywanymi antygenami była glikoproteina $\mathrm{S} 1 \mathrm{z}$ domeną wiążącą receptor, białko nukleokapsydu $\mathrm{N}$ osobno lub razem. W rozwiązaniu tego problemu pomogły testy mikrokulkowe (microspheres bead-based tests), które wykorzystują dwa wirusowe antygeny do wykrywania przeciwciał klasy IgG. Testy wykazywały dokładność rzędu 100 i 99,9\% dokładności dla białek nukleokapsydu i glikoproteiny S [Ayouba i in. 2020].

Mimo że testy serologiczne nie mogą być wykorzystywane do diagnostyki zakażenia koronawirusem trwającego w danym momencie, to są bardzo istotne w badaniu przebiegu oraz epidemiologii choroby. Można dzięki nim badać odpowiedź immunologiczną ilościowo i jakościowo, sprawdzać częstość infekcji na danym obszarze, określając między innymi śmiertelność infekcji. Identyfikacja pacjentów, u których wystąpiła silna odpowiedź układu immunologicznego, może zakwalifikować ich jako potencjalnych dawców do wytwarzania preparatów leczniczych z surowicy i osocza. Ważne jest też badanie korelacji pomiędzy występowaniem przeciwciał a ich ochroną przed powtórnym zarażeniem wirusem [Amanat i in. 2020, WHO 2020]

Metoda molekularna. Drugą metodą stosowaną do identyfikacji COVID-19 jest metoda molekularna oparta na metodzie RealTime PCR (RT-PCR). Testy te wykrywają przynajmniej dwa amplikony specyficzne dla SARS-CoV-2. Bardziej dokładne testy mogą wykrywać dodatkowy trzeci amplikon wirusowy. Wykorzystanie sond i starterów specyficznych dla kilku regionów genomu wirusa, czyli dla różnych genów wirusa, pozwala na zabezpieczenie przed ewentualnymi mutacjami w jego genomie. Metodą molekularną można wykryć zakażenie już przed siódmym dniem po zakażeniu, jednak największe prawdopodobieństwo prawidłowego wyniku występuje pomiędzy 7-14 dniem od zakażenia. Po 14 dniach od zakażenia zanika replikacja wirusa, dlatego konieczne są testy serologiczne [Wojtaszewska 2020]. Wadą tej metody jest jej pracochłonność oraz wysokie koszty. 


\section{Pobieranie próbek}

Najpewniejsze diagnostycznie próbki pochodzą bezpośrednio z drzewa oskrzelowego (BAL - wydzieliny pęcherzykowo-oskrzelowe). Niestety materiał jest trudny do pobrania, dlatego korzysta się z wymazu z noso-gardła, który pobiera się jednorazowymi wymazówkami z materiałów syntetycznych, w celu uniknięcia zafałszowania wyników [Wojtaszewska 2020, WHO 2020].

\section{Szczepionki}

Poszukiwanie skutecznej szczepionki przeciwko wirusowi SARS-CoV-2 jest naglącym wyzwaniem, które jednak jest utrudnione przez słabą znajomość jego właściwości biologicznych i epidemiologii. Niewiele wiadomo o specyficznej odpowiedzi immunologicznej przeciwko SARS-CoV-2. Wiedza zdobyta podczas prób stworzenia szczepionek przeciwko wirusom SARS-CoV i MERS-CoV pozwoliły na szybkie rozpoczęcie pracy, zaledwie kilka tygodni po wybuchu pandemii. Obecnie 7 zespołów na świecie prowadzi badania nad szczepionkami z wirusem inaktywowanym, 28 zespołów zajmuje się szczepionkami podjednostkowymi, około 25 zespołów tworzy szczepionki na bazie wektorów wirusowych oraz 20 zespołów prowadzi badania nad najnowszym typem szczepionek DNA i RNA. Każda z tych szczepionek ma swoje potencjalne wady i zalety [Uddin i in. 2020].

Szczepionki inaktywowane były tworzone po założeniu hodowli wirusów na dużą skalę. Czynniki użyte do inaktywacji to między innymi promieniowanie UV, formaldehyd, $\beta$-propiolakton. Badania nad szczepionkami $\mathrm{z}$ wirusem atenuowanym są także możliwe dzięki namnażaniu wirusa w hodowlach komórkowych i wielokrotnym pasażowaniu w niekorzystnych warunkach, dzięki czemu zmniejsza się ich zjadliwość w porównaniu z wirusem typu dzikiego. W przypadku szczepionek podjednostkowych glikoproteiny S, N, E oraz M mogą stanowić antygeny do stymulowania neutralizujących przeciwciał oraz odpowiedzi limfocytów $\mathrm{T} \mathrm{CD}^{+} / \mathrm{CD} 8^{+}$. Szczepionki podjednostkowe mają jednak bardzo dużą wadę - wymagają wielu szczepień przypominających [Shang i in. 2020].

Jednym z kierunków badań jest przeszukiwanie opisanych epitopów SARS-CoV, łączących się z limfocytami B i T. Epitopy te pochodzą z białek $\mathrm{S}$ oraz N i są identyczne $\mathrm{z}$ białkami SARS-CoV-2. W badanych białkach nie zaobserwowano mutacji od 21.02.2020, co daje potencjał w tworzeniu szczepionki, która będzie warunkowała długotrwałą odporność. W tworzeniu szczepionki istotną rolę w tym przypadku odgrywają też allele MHC występujące w różnych populacjach [Syed i in. 2020].

W przypadku badań nad wirusami SARS-CoV i MERS-CoV najbardziej obiecującymi wydawały się szczepionki DNA, które indukowały odpowiedź ze strony limfocytów B i T oraz były łatwe i szybkie w produkcji. Niestety wywoływały słabszą odpowiedź immunologiczną niż klasyczne szczepionki z wirusem żywym atenuowanym. Zgodnie $\mathrm{z}$ obecnym stanem wiedzy duże nadzieje pokłada się w nowej technologii produkcji szczepionek mRNA. W ich przypadku poprawiono stabilność i efektywność translacji białek, które mogą indukować silną odpowiedź immunolo- 
giczną. Dobrze poznano też metodę dostarczania szczepionki mRNA w nanocząsteczce lipidowej LNP. Tę metodę wykorzystuje się obecnie w Stanach Zjednoczonych, gdzie podano już pierwsze dawki szczepionki mRNA ludziom. Testuje się jej bezpieczeństwo dla organizmów ludzkich [Prompetchara i in. 2020].

\section{Podsumowanie}

Świat po raz kolejny stanął przed problemem, jakim jest pandemia koronawirusa. Najpierw pojawily się wirusy wywołujące SARS, później MERS, a obecnie COVID-19. Objawy zarażenia są bardzo podobne do objawów grypy. Diagnostyka opiera się na testach serologicznych i molekularnych. Metoda serologiczna wykorzystywana jest po wytworzeniu przeciwciał, natomiast metoda molekularna pozwala na wykrycie wirusa przed pojawieniem się przeciwciał. Chorych leczy się lekami przeciwwirusowymi. Naukowcy pracują nad opracowaniem szczepionki zapobiegającej chorobie COVID-19.

\section{Bibliografia}

Amanat F., Stadlbauer D., Strohmeier S., Nguyen T.H., Chromikova V., McMahon M., BermudezGonzalez M., 2020. A serological assay to detect SARS-CoV-2 seroconversion in humans. Nature Med. 26, 1033-1036, https://doi.org/10.1038/s41591-020-0913-5.

Ayouba A., Thaurignac G., Morquin D., Tuaillon E., Raulino R., Nkuba A., Reynes J., 2020. Multiplex detection and dynamics of IgG antibodies to SARS-CoV2 and the highly pathogenic human coronaviruses SARS-CoV and MERS-CoV. J. Clin. Virol. 129, 104521, https://doi.org/10.1016/j.jcv.2020.10452.

Biggerstaff M., Cauchemez S., Reed C., Gambhir M., Finelli L., 2014. Estimates of the reproduction number for seasonal, pandemic, and zoonotic influenza: a systematic review of the literature. BCM Microbiology 14, https://doi.org/10.1186/1471-2334-14-480.

CDC, 2018a. How Flu Spreads, https://www.cdc.gov/flu/about/disease/spread.htm, [dostęp: 27.08.2018]

CDC, 2020b. Symptoms of Coronavirus, https://www.cdc.gov/coronavirus/2019-ncov/symptomstesting/symptoms.html [dostęp: 20.03.2020]

Chih-Cheng L., Tzu-Ping S., Wen-Chien K., Hung-Jen T., Po-Ren H., 2020. Severe Acute Respiratory Syndrome Coronavirus 2 (SARS-CoV-2) and Coronavirus disease-2019 (COVID-19): The Epidemic and the Challenges, Intern. J. Antimicrobial Agents 55, https://doi.org/10.1016/j.ijantimicag.2020.105924.

Elfiky A.A., 2020. Anti-HCV, nucleotide inhibitors, repurposing against COVID-19, Life Sci. 248, https://doi.org/10.1016/j.lfs.2020.117477.

Fang L., 2016. Structure, Function and Evolution of Coronavirus Spike Proteins. Annual Review of Virology, 237-261, https://doi.org/10.1146/annurev-virology-110615-042301.

Gołąb J., Jakóbisiak M., Lasek W., 2006. Immunologia, Wyd. Nauk. PWN, 45-47.

Gupta A., Madhavan M.V., Sehgal K., Nair N., Mahajan S., Sehrawat T.S., Freedberg D.E., 2020. Extrapulmonary manifestations of COVID-19. Nature Med.26(7), 1017-1032, https://doi.org/10.1038/s41591-020-0968-3.

Kliger Y., Levanon E.Y., 2003. Cloaked similarity between HIV-1 and SARS-CoV suggests an anti-SARS strategy. BCM Microbiology 3, https://doi.org/10.1186/1471-2180-3-20. 
Korzeniowski K., 2009. Bliskowschodni zespół niewydolności oddechowej MERS https://medycynatropikalna.pl/choroba/bliskowschodni-zespol-niewydolnosci-oddechowej-mers

Meo S.A., Alhowikan A.M., Al-Khlaiwi T., Meo I.M., Halepoto M.D., Iqbal M., Usmani A.M., Hajjar W., Ahmed N., 2020. Novel Coronavirus 2019-nCoV: Prevalence, Biological and Clinical Characteristics Comparison With SARS-CoV and MERS-CoV, Eur. Rev. Med. Pharmacol. Sci. 24, 2012-2019, https://doi.org/10.26355/eurrev_202002_20379.

Paterlini M., 2020. On the front lines of coronavirus: The Italian response to covid-19, BMJ 368, https://doi.org/10.1136/bmj.m1065.

Pradhan P., Pandey A.K., Mishra A., Gupta P., Tripathi P.K., Meno M.B., Gomes J., Vivekanandan P., Kundu B., 2020. Uncanny similarity of unique inserts in the 2019-nCoV spike protein to HIV-1 gp120 and Gag, Biorxiv, https://doi.org/10.1101/2020.01.30.927871.

Prompetchara E., Ketloy C., Palaga T., 2020. Immune responses in COVID-19 and potential vaccines: lessons learned from SARS and MERS epidemic, Asian Pacific J. Allergy Immunol. 38, 1-9, https://doi.org/10.12932/AP-200220-0772.

Shang W., Yang Y., Rao Y., Rao X., 2020. The outbreak of SARS-CoV-2 pneumonia calls for viral vaccines, npj Vaccines 5, 1-3, doi: 10.1038/s41541-020-0170-0

Shuwen L., Xiao G., Chen Y., He Y., Niu J., Escalante C.R., Xiong H., Farmar J., Debnath A. K., Tien P., Jiang S., 2004. Interaction between heptad repeat 1 and 2 regions in spike protein of SARS-associated coronavirus: implications for virus fusogenic mechanism and identification of fusion inhibitors, The Lancet 363, 938-947, https://doi.org/10.1016/S0140-6736(04)15788-7

Syed F.A., Quadeer A.A., McKay M.R., 2020. Identification of Potential Vaccine Targets for the COVID-19 Coronavirus (SARS-CoV-2) Based on SARS-CoV immunological Studies, Viruses 12, https://doi.org/10.3390/v12030254

Uddin M., Mustafa F., Rizvi T.A., Loney T., Suwaidi H.A., Al-Marzouqi A.H.H., Nowotny N., 2020. SARS-CoV-2/COVID-19: Viral genomics, epidemiology, vaccines, and therapeutic interventions. Viruses, 12, DOI: 10.3390/v12050526

van Doremalen N., Bushmaker T., Morris D., Holbrook M.G., Gamble A., Williamson B.N., Tamin A., Harcourt J., Thornburg N.J., Gerber S., Lloyd-Smith J.O., de Wit E., Munster V.I., 2020. Aerosol and surface stability of HCoV-19 (SARS-CoV-2) compared to SARS-CoV-1, The New England J. Med., https://doi.org/10.1056/NEJMc2004973

Walls A.C., Young-Jun P., Tortorici M.A., Wall A., McGuire A.T., Veesler D., 2020. Structure, Function, and Antigenicity of the SARS-CoV-2 Spike Glycoprotein, Cell https://doi.org/10.1016/j.cell.2020.02.058

WHO, 2012. SARS (Severe Acute Respirator Syndrome) https:/www.who.int/ith/diseases/sars/en/ [dostęp: 26.04.2012]

WHO, 2020. Coronavirus disease (COVID-19) technical guidance: Laboratory testing for 2019-nCoV in humans https://www.who.int/emergencies/diseases/novel-coronavirus-2019/technicalguidance/ laboratory-guidance [dostęp: 24.03.2020]

Wojtaszewska M., 2020. Kompendium wiedzy: diagnostyka molekularna SARS-COV-2 Blog: https: //molekularnie.wordpress.com/about/

Wu A., Peng Y., Huang B., Ding X., Wang X., Niu P., Meng J., Zhu Z., Zhang Z., Wang J., Sheng J., Quan L., Xia Z., Tan W., Cheng G., Jiang T., 2020. Genome Composition and Divergence of the Novel Coronavirus (2019-nCoV) Originating in China, Cell Host and Microbe 27, 325-238, https: //doi.org/10.1016/j.chom.2020.02.001

Zhang W.X., Yap Y.L., 2014. Structural similarity between HIV-1 gp41 and SARS-CoV S2 proteins suggests an analogous membrane fusion mechanism, J. Molecular Structure: TEOCHEM 677, 73-76, https://doi.org/10.1016/j.theochem.2004.02.018

Zhao J., Yuan Q., Wang H., Liu W., Liao X., Su Y., Wang X., Yuan J., Li Z., Li J., Qian S., Hong C., Wang F., Liu Y., Wang Y., He Q., Li Z., He B., Zhang T., Ge S., † Liu L., †, Zhang J., Xia N., Zhang Z., 2020. Antibody responses to SARS-CoV-2 in patients of novel coronavirus disease 2019, Medrxiv, https: //doi.org/10.1101/2020.03.02.20030189 


\author{
Damian Jaguszewski ${ }^{1,4}$, Katarzyna Karpińska ${ }^{1}$, Mateusz Ossowski ${ }^{2}$, \\ Martyna Kasela ${ }^{3}$, Łukasz Wlazło ${ }^{2}$
}

\title{
Natężenie owietlenia w środowisku pracy nauczyciela zatrudnionego w szkole podstawowej
}

Illumination intensity in the work environment of a teacher employed in a primary school

Osoby pracujące na stanowisku nauczyciela, wykonujące swoją prace w salach dydaktycznych są narażone wiele szkodliwych i uciążliwych czynników w tym fizycznych [Dudek i in. 2004,Terelak 2007]. Przebywając w dużych pomieszczeniach, jakimi są sale lekcyjne, nauczyciele często narażeni są na hałas, a także niespełniające odpowiednich parametrów oświetlenie. Złe oświetlenie w czasie przeprowadzania zajęć dydaktycznych traktuje się jako czynnik stresowy [Jóźwiak 2010]. Praca przy za słabym oświetleniu sprzyja powstawaniu błędów oraz wydłuża czas potrzebny do wykonania określonego zadania. Zbyt mocne oświetlanie również wpływa niekorzystnie na pracujące w jego obrębie osoby. Sprawia, że człowiek staje się bardziej nerwowy. Trudniej też mu się skupić na wykonywanym zadaniu. Zastosowanie dobrego oświetlenia sprawia, że osoby będące w pomieszczeniu mogą szybko i bez problemów dostrzegać przedmioty i ich szczegóły, starannie pisać, płynnie czytać czy wykonywać zadania manualne. Podstawą dobrego oświetlania jest zastosowanie odpowiedniej ilości i jakości źródeł światła [Wolska 2010, Grzonkowski i Pracki 2013]. Niestety dostarczenie dużej liczby lamp nie gwarantuje, że oświetlenie w miejscu pracy będzie odpowiednie. Aby praca była komfortowa, źródła światła należy odpowiednio zamontować, a także regularnie wykonywać czynności konserwacyjne, aby nie występowały braki w oświetleniu. Ważne jest, aby nauczyciel w trakcie swojej pracy miał właściwe oświetlenie sprzyjające pracy dydaktycznej oraz zapewniające komfort wzrokowy.

\footnotetext{
${ }^{1}$ SKN Nauk o Zwierzętach i Biogospodarki - Sekcja Higieny Pracy

${ }^{2}$ Katedra Higieny Zwierząt i Zagrożeń Środowiska, Wydział Nauk o Zwierzętach i Biogospodarki, Uniwersytet Przyrodniczy w Lublinie

${ }^{3}$ Katedra i Zakład Mikrobiologii Farmaceutycznej, Wydział Farmaceutyczny, Uniwersytet Medyczny w Lublinie

${ }^{4}$ e-mail: damian0202vp@gmail.com
} 


\section{Światlo i oświetlenie}

Światło (promieniowanie widzialne) jest widzialną częścią promieniowania elektromagnetycznego o długości fali zawierającej się w przedziale od 380 do $780 \mathrm{~nm}$. [http://wikipedia.pl]. Jest to fala elektromagnetyczna zdolna pobudzić siatkówkę i wywołać wrażenie wzrokowe. Oświetlenie sklasyfikowane jest do fizycznych czynników środowiska pracy. Pozwala zapewnić wygodę widzenia stwarzając dobre warunki do wykonywania pracy oraz poprawiając samopoczucie pracowników. Właściwe oświetlenie miejsca pracy uzależnione jest od kilku warunków wynikających z przepisów bhp, psychofizjologii, estetyki i ekonomii. $\mathrm{Na}$ jakość widzenia bezpośrednio wpływają warunki panujące w środkowym polu widzenia, natomiast pośrednio warunki w pozostałych częściach pola widzenia i w tych częściach otoczenia, które przy poruszaniu mogą znaleźć się w obrębie obwodu. Dla ludzkiego oka najlepsze jest światło naturalne.

Właściwe zaprojektowanie oświetlenie miejsca pracy powinno spełniać wymogi w zakresie określonym w normie PN-EN 12464-1. Zapewnienie nieodpowiedniego oświetlenia prowadzić może do powstania niekorzystnych zmian i reakcji organizmu, nadmiernego zmęczenia narządu wzroku, ale też pogłębiać wady wzroku [Górny 2009b]. Symptomem niewłaściwych warunków oświetlenia są m.in. zmęczenie, zaczerwienienie oczu, powiek i spojówek, zmniejszenie ostrości wzroku, nudności. Ważna dla prawidłowego widzenia jest także redukcja efektu olśnienia świetlnego, czyli krótkotrwałego błysku o dużym natężeniu. Należy traktować je jako istotne źródło braku komfortu w pracy, decydujące o sprawności i dokładności wykonywanych czynności roboczych [Górny 2009a]. Rozporządzenie Ministra Pracy i Polityki Społecznej w sprawie ogólnych przepisów bhp [Dz. U. 2003 r. $\mathrm{Nr} 169$, poz. 1650] reguluje przepisy dotyczące tego, że pracodawca zobowiązany jest zapewnić oświetlenie elektryczne o parametrach zgodnych z Polskimi Normami. Wymagania, które są w nim zawarte dotyczą zarówno oświetlenia pomieszczenia i stanowiska pracy, jak i innych części budynku, po którym porusza się pracownik, tj. korytarze czy klatki schodowe.

\section{Parametry oświetlenia}

Jakość oświetlenia opisuje się za pomocą parametrów oświetleniowych definiujących otoczenie świetlne, takich jak: natężenie i równomierność oświetlenia, oddawanie barw (wskaźnik oddania barw), barwa światła (temperatura barwowa), olśnienie, migotanie, tętnienie światła oraz efekt stroboskopowy.

Odpowiednio dobrane parametry do rodzaju stanowiska, pomieszczenia, wykonywanych czynności zgodnie z wymaganiami zawartymi w normie oświetleniowej [PN-EN 12464-1 2004] gwarantuje, że jakość stosowanego oświetlenia będzie odpowiednia [Pawlak 2004, Pawlak 2015].

Natężenie oświetlenia to gęstość powierzchniowa strumienia świetlnego padającego na daną płaszczyznę, czyli jest to ilość światła padająca na powierzchnię, liczona w konkretnym punkcie. Poziom natężenia oświetlenia i jego rozkład w polu 
zadania wzrokowego i jego otoczeniu mają duży wpływ na to, jak szybko, bezpiecznie i wygodnie człowiek dostrzeże i wykona zadanie wzrokowe.

Równomierność oświetlenia wyznacza się jako iloraz najmniejszej zmierzonej wartości natężenia oświetlenia występującej na danej płaszczyźnie do średniego natężenia oświetlenia na tej płaszczyźnie.

Wskaźnik oddania barw jest miarą stopnia zgodności wrażenia barwy przedmiotu oświetlonego danym źródłem światła $\mathrm{z}$ wrażeniem barwy tego samego przedmiotu oświetlonego odniesieniowym źródłem światła w określonych warunkach. Maksymalna możliwa wartość tego wskaźnika wynosi 100. Przyjmuje się ją dla światła dziennego i większości źródeł żarowych. Wartości zbliżone do 100 charakteryzują najlepsze właściwości oddawania barw. Im wyższe jest wymaganie dotyczące właściwego postrzegania barw, tym wskaźnik ten powinien być większy.

Olśnienie jest to pewien stan w procesie widzenia, przy którym występuje odczucie niewygody lub zmniejszenie zdolności rozpoznawania przedmiotów w polu widzenia $\mathrm{w}$ wyniku nadmiernego poziomu luminancji $\mathrm{w}$ polu widzenia bądź niewłaściwego rozkładu luminancji w czasie lub w przestrzeni. Olśnienie powinno być ograniczone, aby unikać błędów, zmęczenia i wypadków.

Temperatura barwowa to wielkość charakteryzująca promieniowanie, określana jako temperatura ciała doskonale czarnego, w której jego promieniowanie ma taką samą chromatyczność (barwa), jak rozpatrywane promieniowanie (widmowy rozkład rozpatrywanego promieniowania nie musi być zgodny z widmowym rozkładem promieniowania ciała czarnego).

Migotanie jest zmianą strumienia świetlnego w rytm zmian prądu przemiennego, od wartości minimalnej do maksymalnej. Migotanie światła występuje w żarówkach w różnym stopniu, zależnie od grubości włókna wolframowego. Jednak problem ten jest bardziej uciążliwy wówczas, gdy stosujemy lampy wyładowcze, przede wszystkim świetlówki.

Tętnienie światła jest jednym z czynników, który wpływa na komfort widzenia przy oświetleniu stanowiska pracy. Tętnienie oświetlenia objawia się szybkimi, periodycznymi zmianami natężenia światła. Zmienny w czasie strumień świetlny wysyłany przez elektryczne źródło światła wynika praktycznie z częstotliwości prądu zasilającego źródło światła.

Efekt stroboskopowy występuje, gdy poruszające się ciało oświetlane jest migającym światłem. Efekt stroboskopowy wywołany tętnieniem światła może powodować niebezpieczne sytuacje $\mathrm{w}$ wyniku zmian w postrzeganiu maszynowych ruchów obrotowych i postępowo-zwrotnych [PN-EN 12464-1 2004, Pawlak 2004, Pawlak 2015].

\section{Dopuszczalne poziomy}

Według rozporządzenia [Dz.U. z 2015 r. poz. 1422] pomieszczenia przeznaczone na pobyt ludzi powinno mieć zapewnione oświetlenie dzienne, a stosunek powierzchni okien, liczonej w świetle ościeżnic, do powierzchni podłogi powinien wynosić w pomieszczeniu przeznaczonym na pobyt ludzi co najmniej $1: 8$, 
natomiast $\mathrm{w}$ innym pomieszczeniu, w którym oświetlenie dzienne jest wymagane ze względu na przeznaczenie - co najmniej $1: 12$. Z kolei oświetlenie sztuczne, które jest niezbędne w szkołach, powinno odpowiadać potrzebom użytkowym i spełniać wymagania odpowiedniej polskiej normy oraz nie powinno wykazywać różnic natężenia, wywołujących olśnienie przy przejściu między tymi pomieszczeniami (stosunek wartości średnich natężenia oświetlenia w pomieszczeniach sąsiadujących ze sobą, przez które odbywa się komunikacja wewnętrzna, nie powinien być większy niż 5 do 1 ).

Zgodnie z normą PN-EN-12464-1 i jej zaleceniami natężenie oświetlenia na płaszczyźnie roboczej $(0,85 \mathrm{~m})$ powinno wynosić min. 300 1x. Wymagana jest też dobra równomierność oświetlenia w polu zadania, czyli w miejscu wykonywania pracy wzrokowej (Emin/Eśr > 0,70). W przypadku, gdy mamy do czynienia z pomieszczeniami o wyższych wymaganiach wzrokowych, np. laboratoria, pracownie artystyczne, tablice itp., należy przyjąć wyższy poziom natężenia oświetlenia - 500 lx. Podstawowe warunki, jakie powinno spełniać oświetlenie w pomieszczeniach szkolnych, zamieszczono w tabeli 1 .

Tabela 1. Wymagania oświetleniowe dla pomieszczeń szkolnych według normy PN EN 12464-1

\begin{tabular}{|c|c|c|c|c|c|}
\hline $\begin{array}{l}\text { Typ obszaru, zadanie } \\
\text { lub działalność }\end{array}$ & $\begin{array}{l}E_{m} \\
l x\end{array}$ & $\begin{array}{l}\mathrm{UGR}_{\mathrm{L}} \\
-\end{array}$ & $\mathrm{U}_{\mathrm{o}}$ & $\begin{array}{l}\mathrm{R}_{\mathrm{a}} \\
-\end{array}$ & Wymagania specyficzne \\
\hline $\begin{array}{l}\text { Klasy, pokoje do } \\
\text { samodzielnej nauki }\end{array}$ & 300 & 19 & 0,60 & 80 & $\begin{array}{l}\text { zaleca się, aby oświetle- } \\
\text { nie było sterowane }\end{array}$ \\
\hline $\begin{array}{l}\text { Klasy do zajęć wie- } \\
\text { czorowych i edukacji } \\
\text { dorosłych }\end{array}$ & 500 & 19 & 0,60 & 80 & $\begin{array}{l}\text { zaleca się, aby oświetle- } \\
\text { nie było sterowane }\end{array}$ \\
\hline $\begin{array}{l}\text { Audytorium, } \\
\text { sale wykładowe }\end{array}$ & 500 & 19 & 0,60 & 80 & $\begin{array}{l}\text { zaleca się, aby oświetle- } \\
\text { nie było sterowane tak, } \\
\text { aby można było zasto- } \\
\text { sować różne wymagania } \\
\text { zasilania }(\mathrm{A} / \mathrm{V})\end{array}$ \\
\hline $\begin{array}{l}\text { Tablice czarne, } \\
\text { zielone i białe }\end{array}$ & 500 & 19 & 0,70 & 80 & $\begin{array}{l}\text { powinna istnieć ochrona } \\
\text { przed lustrzanymi re- } \\
\text { fleksami; } \\
\text { nauczyciel powinien być } \\
\text { oświetlony właściwym } \\
\text { pionowym natężeniem } \\
\text { oświetlenia }\end{array}$ \\
\hline Stół demonstracyjny & 500 & 19 & 0,70 & 80 & $\begin{array}{l}\text { w salach wykładowych } \\
750 \mathrm{~lx}\end{array}$ \\
\hline \multicolumn{6}{|c|}{$\begin{array}{l}\mathrm{E}_{\mathrm{m}}-\text { eksploatacyjne natężenie oświetlenia } \\
\mathrm{UGR}_{\mathrm{L}}-\text { olśnienie przykre } \\
\mathrm{U}_{\mathrm{o}}-\text { równomierność natężenia oświetlenia }-\mathrm{w} \text { obszarze bezpośredniego otoczenia } \geq 0,4 \text {, } \\
\quad \text { w obszarze tła } U_{\mathrm{o}} \geq 0,1 \\
\mathrm{R}_{\mathrm{a}}-\text { wskaźnik oddania barw }\end{array}$} \\
\hline
\end{tabular}




\section{Cel pracy}

Prawidłowe oświetlenie w środowisku pracy nauczyciela jest bardzo ważne, ponieważ zapewnia komfort wzrokowy i nie wywołuje dodatkowego stresu związanego z wykonywaniem powierzonych obowiązków. Dlatego wykonane zostały pomiary natężenia oświetlenia w sali dydaktycznej mające na celu sprawdzenie, czy jest ono odpowiednio dostosowane do pracy nauczyciela i uczniów.

\section{Material i metody}

\section{Pomieszczenie}

Pomiary natężenia oświetlenia przeprowadzono $\mathrm{w}$ godzinach zaplanowanych zajęć, w szkole podstawowej na terenie województwa świętokrzyskiego. Pomieszczeniem, w którym dokonano pomiarów była sala dydaktyczna o wymiarach 7,5 × 7,5 $\times 2,5 \mathrm{~m}$. Światło naturalne zapewniały 3 duże okna. Pomieszczenie było również wyposażone w 6 źródeł światła sztucznego - oprawy typu OKN 236/O HF, a w każdej z opraw zamontowane były po 2 świetlówki marki Philips TL-D 36W. Ich temperatura barwowa wynosiła $4000 \mathrm{~K}$, a współczynnik oddawania barw (Ra) deklarowany przez producenta wynosił 80-89.

Badania polegały na podzieleniu sali na dwa obszary:

- pole zadania - obszar ,w którym nauczyciel wykonuje aktywnie swoją pracę. W tym przypadku, pole to obejmowało swym zasięgiem wszystkie ławki uczniów, biurko nauczyciela oraz przestrzeń wokół nich. Wymiary pole zadania to $6,5 \times 6,5 \mathrm{~m}$. Znajdowało się ono na wysokości blatów ławek/biurka $(70-80 \mathrm{~cm})$. Pole to zostało oznaczone na rycinie (ryc. 1), kwadratem koloru czerwonego;

- pole bezpośredniego otoczenia - powstało przez wydzielenie obszaru po $0,5 \mathrm{~m}$ od każdej ściany.

Postępując zgodnie z normą, kolejnym krokiem było naniesienie siatki na pole zadania i wyznaczenie punktów pomiarowych. Ustalona liczba punktów pomiarowych na podstawie PN-EN 12464-1:2004 wynosiła 16. Odnosząc się jednak do nowych wytycznych zwiększono liczbę punktów pomiarowych do 49, co pozwoli uzyskać większą dokładność prowadzonych badań. Miejsca pomiaru zostały oznaczone na rycinie 1 jako zielone punkty.

W wyznaczonych punktach zostały wykonane pomiary natężenia oświetlenia za pomocą luksomierza Sonopan L-100. Przed wykonaniem badań aparatura została poddana kalibracji. Pomiar wykonano zgodnie z obowiązującą normą. 


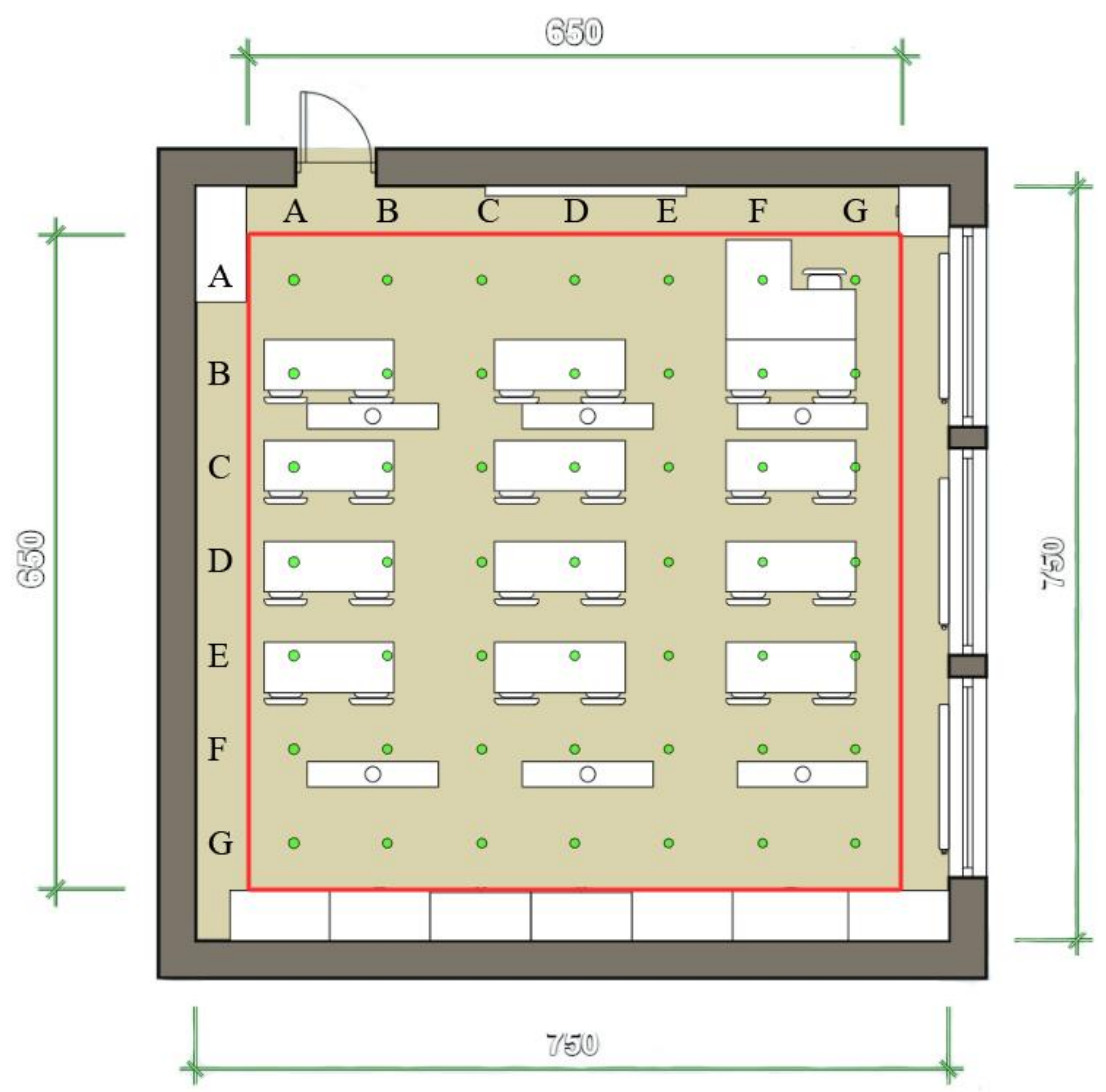

Ryc. 1. Schemat sali dydaktycznej, z wydzielonym polem zadania. A-G - punkty pomiarowe. Opracowanie własne

Przeprowadzone pomiary pozwolił na obliczenie równomierności oświetlenia w badanym obiekcie. Do obliczeń wykorzystano wzór zapisany w PN 12464-1.

a) równomierność oświetlenia

$$
U_{\circ}=\frac{E_{\min }}{E_{s r}}
$$

gdzie:

$\mathrm{U}_{\mathrm{o}}$ - równomierność oświetlenia;

$\mathrm{E}_{\min }$ - najmniejszej zmierzonej wartości natężenia oświetlenia występującej na danej płaszczyźnie;

$\mathrm{E}_{\mathrm{sr}}-$ średniego natężenia oświetlenia na tej płaszczyźnie. 


$$
E_{\xi r}=\frac{\left(E_{1}+E_{2}+\ldots+E_{n}\right)}{n}
$$

gdzie:

$n$ - liczba punktów pomiarowych,

$E_{l}, E_{n}$ - wyniki pomiarów w kolejnych punktach pomiarowych,

Po przeprowadzeniu badań uzyskane wartości odniesione zostały do PN 12464-1.

\section{Analiza wyników badań}

Wyniki przeprowadzonych pomiarów zostały przedstawione w tabeli 2.

Tabela 2. Wyniki przeprowadzonych pomiarów natężenia oświetlenia w sali [lx]

\begin{tabular}{|l|c|c|c|c|c|c|c|}
\hline $\begin{array}{c}\text { Punkty } \\
\text { pomiarów }\end{array}$ & A & B & C & D & E & F & G \\
\hline A & 216 & 225 & 257 & 278 & 291 & 299 & 320 \\
B & 230 & 244 & 272 & 295 & 328 & 294 & 324 \\
C & 255 & 274 & 303 & 331 & 352 & 339 & 328 \\
D & 274 & 308 & 331 & 329 & 332 & 336 & 340 \\
E & 278 & 301 & 328 & 335 & 348 & 339 & 337 \\
F & 253 & 269 & 296 & 312 & 324 & 333 & 339 \\
G & 250 & 262 & 302 & 307 & 314 & 329 & 344 \\
\hline
\end{tabular}

Zakres wskazanych przez luksomierz wartości w trakcie pomiarów wynosiło od 216 lx do 352 lx (tab. 2). Natomiast średnie natężenie oświetlenia wyniosło 302 lx. Wyliczona równomierność oświetlenia zgodnie z PN wynosi 0,72 . Graficzny rozkład natężenia oświetlenia w sali dydaktycznej przedstawiono na rycinie 3 .

Analizując wyniki pomiarów, należy stwierdzić, że w sali dydaktycznej występuje odpowiednie oświetlenie. Wykorzystane w sali źródła światła sztucznego zapewniają odpowiedni poziom natężenia oświetlenia - zgodny z normą, mimo że część pomieszczenia, w którym znajdują się drzwi, jest słabiej oświetlona. $\mathrm{Na}$ podstawie wielkości natężenia oświetlenia obliczono równomierność oświetlenia, współczynnik oddawania barw. Uzyskane wartości spełniały wymagania aktualnej 


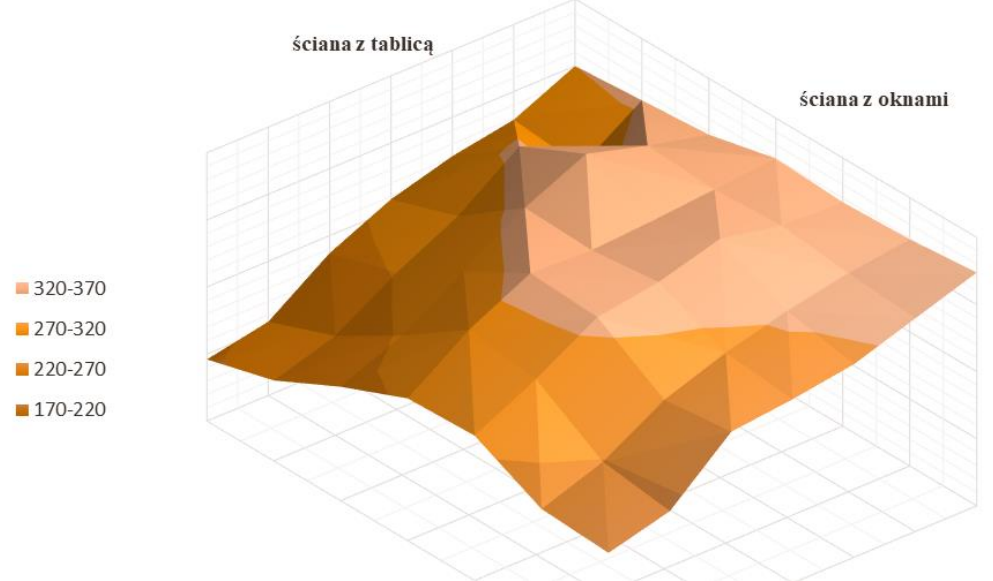

Ryc. 3. Rozkład natężenia oświetlenia w sali dydaktycznej. Opracowanie własne

normy [PN-EN 12464-1]. Zastosowana w sali dydaktycznej temperatura barwowa (4000 K), była odpowiednia przy pracy wymagającej skupienia. Stosunek powierzchni okien do powierzchni podłogi $\mathrm{w}$ badanym pomieszczeniu jest zgodny $\mathrm{z}$ regulującym to rozporządzeniem [Dz.U. z 2015 r. poz. 1422].

\section{Podsumowanie i wnioski}

Na podstawie wyników z przeprowadzonych badań stwierdzono, że eksploatacyjne natężenie oświetlenia $\mathrm{w}$ badanym pomieszczeniu jest właściwe, a samo pomieszczenie nie wymaga zmiany oświetlenia.

Stanowisko pracy nauczyciela jest odpowiednio dostosowane do pracy, co potwierdzają analizowane parametry oświetleniowe, które wpływają na bezpieczeństwo pracy i wygodę widzenia.

\section{Bibliografia}

CIE 17.4:1987. Międzynarodowy słownik oświetleniowy. Część 845: Oświetlenie, Międzynarodowa Komisja Oświetleniowa (CIE).

CIE 97.2:2005. Guide on the Maintenance of Indoor Electric Lighting Systems, Międzynarodowa Komisja Oświetleniowa (CIE).

Dudek B., Waszkowska M., Merecz D., Hanke W., 2004. Ochrona zdrowia pracowników przed skutkami stresu zawodowego, Inst. Med. Pracy, Łódź.

Górny A., 2009a. Kształtowanie warunków oświetleniowych jako czynnika minimalizacji uciążliwości pracy. W: J. Charytonowicz (red.), Wybrane kierunki badań ergonomicznych w 2009 roku, Wyd. Pol. Tow. Ergon. PTErg, Oddział we Wrocławiu, Wrocław, 59-70. 
Górny A., 2009b. Wymagania oświetleniowe w ocenie ryzyka zawodowego na stanowisku pracy. W: J. Charytonowicz (red.), Wybrane kierunki badań ergonomicznych w 2009 roku. Wyd. Pol. Tow. Ergon. PTErg, Oddział we Wrocławiu, Wrocław, 111-124.

Grzonkowski J., Pracki P. (red.), 2013. Technika świetlna, t. 3. Praca zb. członków Pol.. Kom. Oświetleniowego Stow. Elektryków, Warszawa.

http://www.wikipedia.pl/światło.

Jóźwiak Z., 2010. Fizyczne warunki pracy nauczycieli. W: J. Pyżalski, D. Merecz (red.), Psychospołeczne warunki pracy polskich nauczycieli, Kraków.

Marzec S., 2008. Badanie oświetlenia elektrycznego we wnętrzach. DASL Systems, Kraków.

Norma PN EN 12464-1:2004 Światło i oświetlenie. Oświetlenie miejsc pracy, Część 1: Miejsca pracy we wnętrzach.

Pawlak A., 2015, Przystosowanie oświetlenia elektrycznego środowiska pracy dla osób słabowidzących. Bezpieczeństwo pracy: nauka i praktyka nr 2 23-27.

Pawlak W., 2004, Oświetlenie miejsc pracy we wnętrzach - nowa norma oświetleniowa. W: Bezpieczeństwo Pracy, 10, 6-10.

Rozporzązenie Ministra Edukacji Narodowej i Sportu z dnia 31 grudnia 2002 r. w sprawie bezpieczeństwa i higieny w publicznych i niepublicznych szkołach i placówkach. Dz. U. z 2003 r. Nr 6, poz. 69,

Rozporządzenie Ministra Infrastruktury z dnia 12 kwietnia 2002 r. w sprawie warunków technicznych, jakim powinny odpowiadać budynki i ich usytuowanie, tekst jednolity Dz.U. z 2015 r. poz. 1422.

Rozporządzenie Ministra Pracy i Polityki Socjalnej z dnia 1 grudnia 1998 r. w sprawie bezpieczeństwa $\mathrm{i}$ higieny pracy na stanowiskach wyposażonych $\mathrm{w}$ monitory ekranowe.

Rozporządzenie Ministra Pracy i Polityki Socjalnej z dnia 26 września 1997 r. w sprawie ogólnych przepisów bezpieczeństwa i higieny pracy. Dz. U. z 2003 r. Nr 169, poz. 1650.

Terelak J.F., 2007. Stres zawodowy. Charakterystyka psychologiczna wybranych zawodów stresowych, Wyd. UKSW, Warszawa.

Wolska A., 2010. Oświetlenie miejsc pracy we wnętrzach - stan prawny, Bezpieczeństwo Pracy, $10,10-11$. 


$$
\begin{gathered}
\text { Damian Zarębski }{ }^{1,2}, \text { Szymon Chmielewski }^{1}, \text { Adam Gawryluk }^{1} \text {, } \\
\text { Ilona Woźniak-Kostecka }
\end{gathered}
$$

\section{Projekt lokalizacji ogniw fotowoltaicznych na wybranych budynkach miasta Lubartów}

Project of the location photovoltaic cells on selected buildings in the Lubartów city

Rozwój cywilizacji od początku oparty był na wykorzystaniu minerałów oraz zasobów energetycznych Ziemi, których wyczerpanie jest nieuniknione i wyraźnie widoczne we wciąż rosnących cenach ropy i gazu. Pogarszający się stan środowiska zauważalny jest m.in. nie tylko w zwiększonym stężeniu dwutlenku węgla w atmosferze, powodującym ekstrema pogodowe, ale również we wzroście zainteresowania odnawialnymi źródłami energii (OZE). Spośród wszystkich naturalnie dostępnych źródeł Słońce może dostarczyć największą ilość energii, ze względu na to, że jego promieniowanie dociera do Ziemi nieustannie. Energia słoneczna jest ogólnodostępnym dobrem, a jej przetworzenie na energię elektryczną za pomocą ogniw fotowoltaicznych z roku na rok staje się coraz bardziej popularna z powodu coraz niższych kosztów produkcji i możliwości technicznych ogniw [Nowicki 2012, Mertens 2014].

Zrównoważony rozwój jest jednym $\mathrm{z}$ aspektów planowania przestrzennego, rozumianego jako optymalne wykorzystanie dostępnych zasobów naturalnych w taki sposób, aby nie ograniczać ich przyszłym pokoleniom [Kronenberg i Bergier 2010]. Poszukiwanie alternatywnych źródeł energii oraz możliwości ich adaptacji do lokalnych warunków jest zatem bardzo ważne. W kontekście planowania przestrzennego optymalne wykorzystanie OZE może zostać osiągnięte m.in. poprzez odpowiednie planowanie niskoemisyjnej zabudowy oraz zapisy w dokumentach planistycznych, tworzących korzystne warunki do montażu instalacji fotowoltaicznych. Systemy GIS (ang. Geographic Information Systems) oferują bogate narzędzia analityczne do przetwarzania i analizy danych przestrzennych i stanowią obecnie jedno z najpopularniejszych narzędzi wykorzystywanych do wspomagania decyzji projektowych i planistycznych [Hejmanowska 2006].

\footnotetext{
${ }^{1}$ Katedra Łąkarstwa i Kształtowania Krajobrazu, Zakład Studiów Krajobrazowych i Gospodarki Przestrzennej, Wydział Agrobioinżynierii, Uniwersytet Przyrodniczy w Lublinie

2 e-mail: zarebskidamian@wp.pl
} 


\section{Cel prowadzonych badań}

Głównym celem pracy było opracowanie uniwersalnej metody wyznaczania potencjału terenu do montażu ogniw fotowoltaicznych $\mathrm{z}$ określeniem wartości nasłonecznienia połaci dachowych oraz ich potencjału do montażu ogniw, a także korzyści finansowych wynikających z możliwości pozyskania energii elektrycznej $\mathrm{z}$ instalacji fotowoltaicznej na przykładzie osiedla Kopernika w Lubartowie.

\section{Metody badań}

Pierwszym etapem badań było pozyskanie danych przestrzennych z Głównego Urzędu Geodezji i Kartografii oraz Geoportalu Krajowego dla osiedla Kopernika w Lubartowie. Teren opracowania został wybrany ze względu na występowanie zwartej zabudowy mieszkaniowej, gdzie stan techniczny budynków pozwala na montaż ogniw fotowoltaicznych [Plan Gospodarki Niskoemisyjnej dla miasta Lubartów 2015]. Następnie za pomocą funkcji programu ArcGIS pozyskane dane przestrzenne umieszczono $\mathrm{w}$ geobazie i wykorzystano do opracowania analiz przestrzennych. Modele 3D budynków przekonwertowano z wykorzystaniem oprogramowania FME Data Inspector. Pliki w formacie .gml zapisano jako ESRI Geodatabase, z której zaimportowano warstwę „RoofSurface_surface.shp”, zawierającą obrysy połaci dachowych, dla których obliczono powierzchnię. Zbiór danych pomiarowych, czyli chmurę punktów 3D pochodzącą z lotniczego skaningu laserowego (LIDAR) poddano filtracji, pozostawiając aktywne punkty należące do klas: Ground (Grunt), High Vegetation (Roślinność wysoka) oraz Building (Budynki). Na podstawie tak przygotowanej chmury punktów 3D wygenerowano Numeryczny Model Pokrycia Terenu (NMPT), który poddano geoprzetwarzaniu, czyli modyfikacji i przeobrażeniu za pomocą narzędzia Area Solar Radiation w programie ArcGIS Pro, co pozwoliło na obliczenie nasłonecznienia dla obszaru całego miasta. Następnie posłużono się narzędziem ZonalStatistics, które umożliwiło obliczenie wartości nasłonecznienia $\mathrm{w}$ granicach danej strefy. Warstwą definiującą strefy były obrysy połaci dachowych (z wygenerowanego wcześniej potencjału solarnego), dla których określono średnią wartość nasłonecznienia z dokładnością do $1 \mathrm{~m}$. W celu określenia nachylenia połaci dachowych raster NMPT przycięto do obrysów połaci dachowych. Wykorzystano narzędzie Slope z oprogramowania ArcGIS Pro, za pomocą którego obliczono nachylenie dachu, wykorzystując różnice wysokości na połaciach dachowych. Następnym etap obejmował pozyskanie informacji o wymogach technicznych instalacji fotowoltaicznych, z których wynika, że połać dachowa powinna mieć odpowiednio dużą powierzchnię, aby pomieścić ogniwa fotowoltaiczne. Na budynkach mieszkalnych $\mathrm{z}$ reguły montuje się instalacje o minimalnej mocy $3 \mathrm{~kW}$. W pracy przyjęto, że instalacja o mocy $3 \mathrm{~kW}$ zajmie powierzchnię około $21 \mathrm{~m}^{2}$ dachu, instalacja o mocy $4 \mathrm{~kW}$ zajmie $28 \mathrm{~m}^{2}$, zaś dla $5 \mathrm{~kW}$ będzie to $35 \mathrm{~m}^{2}$ powierzchni dachu [StiloEnergy]. 
W części projektowej uwzględniono jedynie połacie dachowe, których nasłonecznienie jest korzystne pod względem montażu ogniw (nasłonecznienie $>8000 \mathrm{Wh} / \mathrm{m}^{2}$ ), optymalna ekspozycja to kierunek południowy, zaś nachylenie połaci mieści się w przedziale 30-45 [Klugmann-Radziemska 2010, Oszczak 2012]. Do części projektowej wybrano połacie spełniające 3 powyższe kryteria. Dodatkowo przyjęto, że połacie dachowe nie mogą posiadać pokrycia $\mathrm{z}$ azbestu i elementów rzucających cień, które mogą utrudniać pracę ogniw (np. maszty antenowe, lukarny).

W analizie opłacalności inwestycji przyjęto, że instalacja o mocy $3 \mathrm{~kW}$ kosztuje średnio ok. $15000 \mathrm{zl}$, natomiast zakup instalacji o mocy $4 \mathrm{~kW}$ to koszt w przybliżeniu $20000 \mathrm{zl}$, a ok. $25000 \mathrm{zł}$ kosztuje instalacja fotowoltaiczna o mocy $5 \mathrm{~kW}$. Z kolei na podstawie danych Głównego Urzędu Statystycznego (GUS) założono, że zużycie energii elektrycznej w Lubartowie w 2018 r. na 1 os. wynosiło ok. 766,63 kWh [Bank Danych Lokalnych 2018]. Na podstawie tych danych, wykorzystując kalkulator opłacalności opracowany przez Sławomira Zająca [blog.poradnik-budowlany.com], obliczono po ilu latach możliwy jest zwrot kosztów zakupu i montażu instalacji o danej mocy. W analizach przyjęto możliwość wykorzystania środków własnych na sfinansowanie inwestycji, jak również możliwość skorzystania z programu „Mój prąd”, w którym uzyskać można dofinansowanie dla instalacji o mocy $2-10 \mathrm{~kW}$ w formie dotacji, maksymalnie 50\% kosztów, ale nie więcej niż 5000 zł [Portal gov.pl - Serwis Rzeczypospolitej Polskiej].W analizach przyjęto, że cena za $1 \mathrm{kWh}$ energii elektrycznej to koszt ok. $0,58 \mathrm{zl}$, jak również, że stałe koszty energii to koszt ok. $100 \mathrm{zz} /$ rok, a wzrost cen energii to $1 \%$ rocznie. Założono także, że na bieżąco zużywane będzie ok. $30 \%$ produkowanej energii, zaś nadwyżka przesyłana będzie do sieci z możliwością jej późniejszego odbioru [GLOBEnergia].

\section{Wyniki badań}

Przeprowadzone analizy wykazały, że na analizowanym obszarze (osiedle Kopernika w Lubartowie) stwierdzono 617 połaci o powierzchni mniejszej lub równej $20 \mathrm{~m}^{2}, 245$ połaci o powierzchni w przedziale 21-27 $\mathrm{m}^{2}$ (umożliwiającej montaż instalacji o mocy $3 \mathrm{~kW}), 193$ połacie o powierzchni w przedziale $28-34 \mathrm{~m}^{2}$ (umożliwiające montaż instalacji o mocy $4 \mathrm{~kW}$ ) oraz 672 połacie o powierzchni większej lub równej $35 \mathrm{~m}^{2}$ (umożliwiającej montaż instalacji o mocy $5 \mathrm{~kW}$ ). Analiza nachylenia połaci dachowych wykazała, że na analizowanym obszarze występuje 455 połaci, których nachylenie mieści się w przedziale $30-45^{\circ}$. Z kolei analiza nasłonecznienia wykazała 656 połaci, których wartość nasłonecznienia wynosi powyżej $8000 \mathrm{Wh} / \mathrm{m}^{2}$.

Wykorzystując wyniki przeprowadzonych analiz, opracowano trójstopniową klasyfikację połaci dachowych pod względem ich przydatności do montażu ogniw fotowoltaicznych. Połacie dachowe, które mają niedostateczne nasłonecznienie (wartość poniżej $6000 \mathrm{Wh} / \mathrm{m}^{2}$ ) oraz zbyt małą powierzchnię sklasyfikowano 
jako słabe pod względem potencjału do montażu ogniw. Połacie, których powierzchnia jest większa niż $21 \mathrm{~m}^{2}$, a wartość nasłonecznienia wynosi mniej niż $6000 \mathrm{Wh} / \mathrm{m}^{2}$ to połacie ze średnim potencjałem. Natomiast połacie potencjalnie dobre charakteryzują się nasłonecznieniem o wartości powyżej $8000 \mathrm{Wh} / \mathrm{m}^{2}$, ich powierzchnia jest większa niż $21 \mathrm{~m}^{2}$, a kąt nachylenia mieści się $\mathrm{w}$ przedziale $30-45^{\circ}$. Na podstawie wykonanych analiz do projektu zakwalifikowano jedynie 17 połaci dachowych, dla których przygotowano projekt montażu ogniw fotowoltaicznych (ryc. 1). W projekcie założono, że instalacja fotowoltaiczna będzie systemem on-grid, czyli zostanie połączona z siecią energetyczną. Jest to rozwiązanie pozwalające $\mathrm{w}$ ciągu dnia na korzystanie $\mathrm{z}$ energii elektrycznej wyprodukowanej przez instalację, a po zachodzie Słońca z energii elektrycznej z sieci energetycznej.
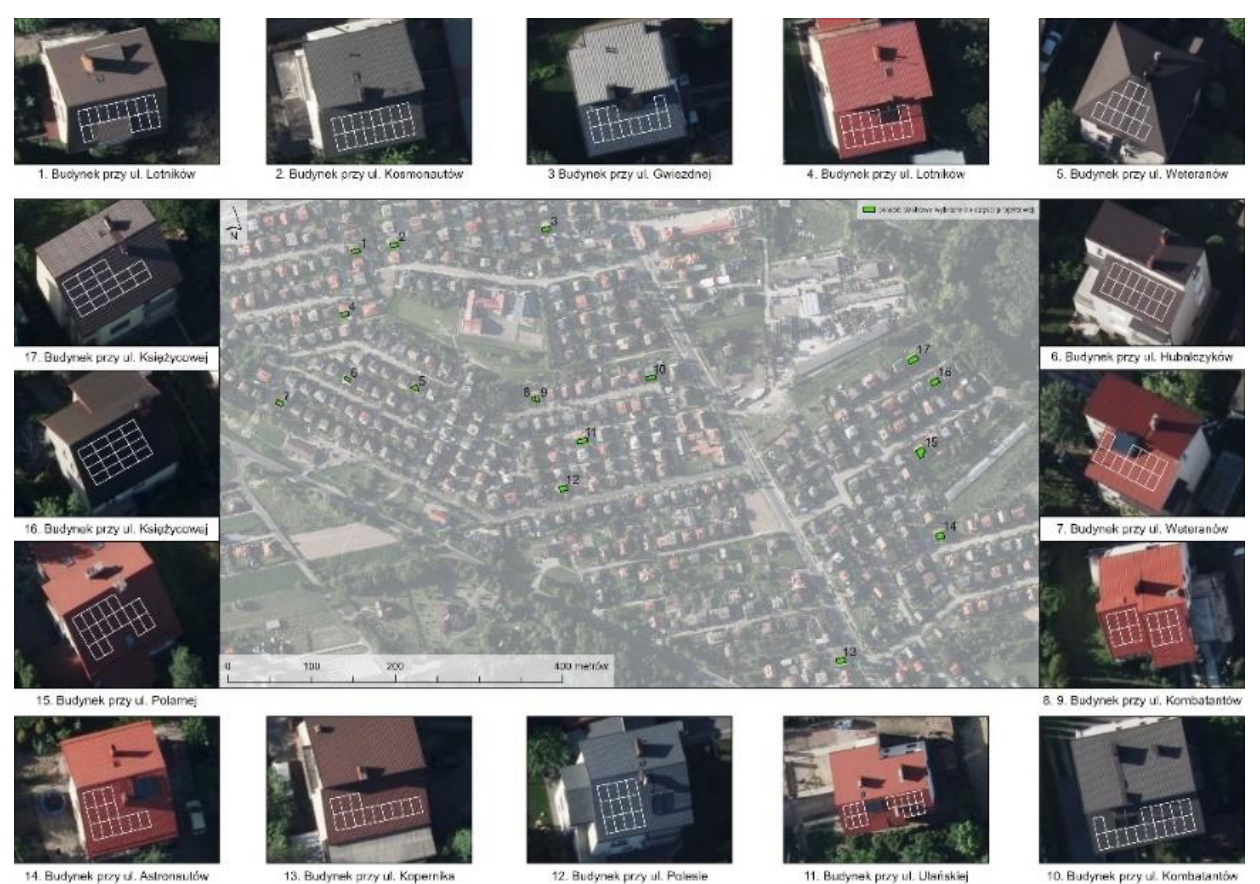

Ryc. 1. Projekt lokalizacji ogniw fotowoltaicznych na połaciach dachowych. Opracowanie własne na podstawie danych udostępnionych przez GUGiK

Kolejnym etapem była analiza opłacalności, która wykazała, że w perspektywie długoterminowej najbardziej opłacalny dla rodziny 3-osobowej jest zakup i montaż instalacji fotowoltaicznej o mocy $3 \mathrm{~kW}$. Instalacja o mocy $4 \mathrm{~kW}$ opłaca się rodzinie 4-osobowej, a rodzina 5-osobowa najbardziej skorzysta na inwestycji w instalację o mocy $5 \mathrm{~kW}$. Wszystkie te inwestycje przy wykorzystaniu środków własnych zwrócą się w okresie ok. 10 lat (koszt zakupu prądu równy zakupowi i montażowi instalacji fotowoltaicznej). W ciągu 25 lat koszty zakupu energii 
Tabela 1. Czas zwrotu inwestycji i wartość oszczędności w wyniku zakupu i montażu instalacji fotowoltaicznej wyłącznie ze środków własnych w gospodarstwach 3-, 4-, 5-osodowych w zależności od mocy instalacji fotowoltaicznej i zużycia energii elektrycznej. Opracowanie własne na podst. [blog.poradnik-budowlany.com]

\begin{tabular}{|c|c|c|c|}
\hline \multirow{2}{*}{ Parametr } & \multicolumn{3}{|c|}{ Gospodarstwa } \\
\hline & 3-osobowe & 4-osobowe & 5-osobowe \\
\hline $\begin{array}{l}\text { Moc instalacji fotowoltaicznej } \\
\text { i cena zakupu }\end{array}$ & $\begin{array}{c}3 \mathrm{~kW} \\
15000 \mathrm{zl}\end{array}$ & $\begin{array}{c}4 \mathrm{~kW} \\
20000 \mathrm{zl}\end{array}$ & $\begin{array}{c}5 \mathrm{~kW} \\
25000 \mathrm{zl}\end{array}$ \\
\hline $\begin{array}{l}\text { Cena instalacji } \\
(\text { za } 1 \mathrm{~kW})\end{array}$ & $5000 \mathrm{zl}$ & $5000 \mathrm{zl}$ & $5000 \mathrm{zl}$ \\
\hline Aktualne roczne zużycie prądu & $2299,89 \mathrm{kWh}$ & $3066,52 \mathrm{kWh}$ & $3833,15 \mathrm{kWh}$ \\
\hline $\begin{array}{l}\text { Czas zwrotu kosztów na zakup } \\
\text { i montaż instalacji fotowoltaicznej }\end{array}$ & 10 lat & 10 lat & 10 lat \\
\hline $\begin{array}{l}\text { Całkowity koszt energii elektrycz- } \\
\text { nej bez fotowoltaiki przez } 25 \text { lat }\end{array}$ & $40498,95 \mathrm{zl}$ & 53 057,15zł & $65615,36 \mathrm{zl}$ \\
\hline $\begin{array}{l}\text { Całkowita oszczędność dzięki } \\
\text { instalacji fotowoltaicznej w ciągu } \\
25 \text { lat }\end{array}$ & $21883,68 \mathrm{zł}$ & $29178,24 \mathrm{zl}$ & $36472,80 \mathrm{zl}$ \\
\hline
\end{tabular}

Tabela 2. Czas zwrotu inwestycji i wartość oszczędności w wyniku zakupu i montażu instalacji fotowoltaicznej w gospodarstwach 3-, 4-, 5-osodowych ze środków własnych wraz z dofinansowaniem w zależności od mocy instalacji i zużycia energii elektrycznej. Opracowanie własne na podst. [blog.poradnik-budowlany.com]

\begin{tabular}{|l|c|c|c|}
\hline \multicolumn{1}{|c|}{ Parametr } & \multicolumn{3}{|c|}{ Gospodarstwa } \\
\cline { 2 - 4 } & 3-osobowe & 4 -osobowe & 5 -osobowe \\
\hline $\begin{array}{l}\text { Moc instalacji fotowol- } \\
\text { taicznej i cena zakupu }\end{array}$ & $\begin{array}{c}3 \mathrm{~kW} \\
15000 \mathrm{zł}\end{array}$ & $\begin{array}{c}4 \mathrm{~kW} \\
20000 \mathrm{zł}\end{array}$ & $\begin{array}{c}5 \mathrm{~kW} \\
25000 \mathrm{zł}\end{array}$ \\
\hline $\begin{array}{l}\text { Cena instalacji } \\
\text { (za 1 kW) }\end{array}$ & $\begin{array}{c}3333,34 \mathrm{zł} \\
\text { (ulga } 5000 \mathrm{zł}, \mathrm{czyli} \\
1666,66 \mathrm{zł} / 1 \mathrm{~kW})\end{array}$ & $\begin{array}{c}3750 \mathrm{zł} \\
\text { (ulga } 5000 \mathrm{zł}, \mathrm{czyli} \\
1250,00 \mathrm{zł} / 1 \mathrm{~kW})\end{array}$ & $\begin{array}{c}4000 \mathrm{zł} \\
\text { (ulga 5000 zł, czyli } \\
1000,00 \mathrm{zł} / 1 \mathrm{~kW})\end{array}$ \\
\hline $\begin{array}{l}\text { Aktualne roczne } \\
\text { zużycie prądu }\end{array}$ & $2299,89 \mathrm{kWh}$ & $3066,52 \mathrm{kWh}$ & $3833,15 \mathrm{kWh}$ \\
\hline $\begin{array}{l}\text { Czas zwrotu kosztów } \\
\text { na zakup i montaż insta- } \\
\text { lacji fotowoltaicznej }\end{array}$ & 7 lat & 8 lat & 8 lat \\
\hline $\begin{array}{l}\text { Całkowity koszt energii } \\
\text { elektrycznej bez foto- } \\
\text { woltaiki przez 25 lat }\end{array}$ & $40498,95 \mathrm{zł}$ & $53057,15 \mathrm{zł}$ & $65615,36 \mathrm{zł}$ \\
\hline $\begin{array}{l}\text { Całkowita oszczędność } \\
\text { dzięki instalacji fotowol- } \\
\text { taicznej w ciągu 25 lat }\end{array}$ & $26883,66 \mathrm{zł}$ & $34178,24 \mathrm{zł}$ & $41472,80 \mathrm{zł}$ \\
\hline
\end{tabular}


elektrycznej bez posiadania instalacji wzrosłyby dla rodziny 3-, 4- i 5-osobowej (odpowiednio do 40 498,95 zł; 53 057,15zł i 65 615,36 zł). Analiza czasu zwrotu inwestycji wykazała, że montaż instalacji fotowoltaicznej daje prawie $50 \%$ oszczędności na zakupie energii elektrycznej w ciągu 25 lat, z uwzględnieniem znacznego zmniejszenia sprawności instalacji (tab. 1).

Przeprowadzone analizy wykazały, że w przypadku skorzystania $\mathrm{z}$ dofinansowania moc najbardziej opłacalnej instalacji dla poszczególnych rodzin nie zmieni się. Różnice wystąpią w czasie zwrotu inwestycji, ze względu na powiązanie pomiędzy ceną instalacji a zużyciem i kosztem energii. Wysokość ulgi w przeliczeniu na $1 \mathrm{~kW}$ maleje wraz ze wzrostem mocy instalacji. Jednocześnie im większe zużycie energii i moc instalacji, tym długoterminowa oszczędność jest większa i w przypadku skorzystania $\mathrm{z}$ dofinansowania stanowi ponad $60 \%$ kosztów, które potencjalnie poniosłyby rodziny w przypadku braku instalacji fotowoltaicznej (tab. 2).

\section{Dyskusja}

GIS jest jednym z narzędzi stosowanych w planowaniu przestrzennym, jednak ze względu na swoją uniwersalność może być również wykorzystywany do badania potencjału terenu w kierunku montażu ogniw fotowoltaicznych. Posiadając dane dotyczące geometrii dachu, można wykonać szereg analiz, określających poziom potencjału solarnego danego budynku lub zespołu budynków. Podobne wyniki otrzymali Krawczyk i in. [2018], którzy podkreślają, że w zależności od wykorzystanego w programie typu geometrii (wektor lub chmura punktów) można uzyskać różne wartości wyników nasłonecznienia. Zatem, aby uzyskać rzeczywiste wartości, należy wziąć pod uwagę zjawiska przenikania, rozpraszania i pochłaniania promieni słonecznych, a także efekt zacienienia wywoływany m.in. obecnością obiektów pochodzenia antropogenicznego (elementy konstrukcji dachu lub budynku czy naziemna infrastruktura techniczna), a także roślinności [Kolendo i Krawczyk 2016].

Przeprowadzone badania wykazały, że bardzo ważnym czynnikiem podczas analiz lokalizacji ogniw fotowoltaicznych jest czynnik ludzki (podejście eksperckie), który w znacznym stopniu może wpływać na końcowy wynik analiz. Do podobnych wniosków doszedł Piskorski [2017].

Bardzo ważnym elementem planowania lokalizacji ogniw fotowoltaicznych jest określenie opłacalności tego typu inwestycji, uzależnionej od możliwości zwrotu poniesionych nakładów finansowych. Według przeprowadzonych badań instalacja fotowoltaiczna sfinansowana ze środków własnych zwróci się po ok. 10 latach. Proces ten jest bardzo złożony, co potwierdzają inne opracowania na ten temat. Według Jurasz i in. [2013] taka instalacja może się zwrócić finansowo dopiero po 14-15 latach. Wynika to głównie z ciągle zmieniającej się technologii i materiałów, z których budowane są ogniwa. Pietras-Szewczyk [2014] na- 
tomiast zwraca uwagę, że poza czynnikiem ekonomicznym warto również uwzględnić możliwe zyski ekologiczne, które związane są ze zmianą dotychczas wykorzystywanych źródeł energii na alternatywne. Jednym z przykładów określenia takiego zysku jest obliczenie efektu ekologicznego, polegającego na zmniejszeniu ilości emisji $\mathrm{CO}_{2}$ do atmosfery [Gużda i Szmolke 2017].

Według Nawrota [2017] istnieje konieczność regulacji związanych z OZE w miejscowych planach zagospodarowania przestrzennego. Dla terenu, na którym uchwalony został plan miejscowy, istnieje wiele nowych możliwości związanych z lokalizacją OZE. Przede wszystkim zapisy planu mogą pozwolić na lokalizację kilku rodzajów instalacji OZE. Z drugiej strony plan miejscowy może dopuszczać powstanie tylko jednego rodzaju instalacji, wprowadzając ograniczenia dla przyszłych inwestorów, a także wpływając pozytywnie na jakość krajobrazu. Miejscowy plan zagospodarowania może również uniemożliwiać montaż instalacji OZE na terenach, gdzie jest to nierentowne. Takie zapisy są niezwykle ważne i mogą pomóc w budowaniu energooszczędnej polityki gminy. Korzystanie $\mathrm{z}$ fotowoltaiki idealnie wpisuje się $\mathrm{w}$ koncepcję zrównoważonego rozwoju, ponieważ ograniczając emisję zanieczyszczeń, pochodzących ze spalania paliw kopalnych na rzecz wykorzystania odnawialnych źródeł energii, zapewniamy przyszłym pokoleniom równy dostęp do dóbr środowiskowych.

Wykorzystaną metodykę badań można $\mathrm{z}$ powodzeniem zaadaptować $\mathrm{w}$ innych gminach. Jest to szczególnie ważne $\mathrm{w}$ związku $\mathrm{z}$ obowiązkiem opracowania przez gminy założeń do planów zaopatrzenia gmin w energię elektryczną, ciepło i paliwa gazowe uregulowane w nowelizacji ustawy Prawo energetyczne z dnia 10 kwietnia $1997 \mathrm{r}$. Niniejsze opracowanie może być przydatne zarówno organom administracji samorządowej (w celu podejmowania decyzji i określenia potencjału solarnego na danym terenie), jak i obywatelom, którzy za pomocą interaktywnych map i kalkulacji kosztów, mogą przekonać się, że przejście na OZE może być opłacalne.

Rosnąca liczba instalacji fotowoltaicznych prowadzić będzie do powstania inteligentnych sieci energetycznych ( $\mathrm{z}$ ang. smart grid), które umożliwią komunikację między wszystkimi użytkownikami sieci, np. w obrębie miejscowości, dzielnicy, obniżenie kosztów, zwiększenie efektywności oraz połączenie rozproszonych źródeł energii, jakimi są instalacje fotowoltaiczne. W przyszłości takie sieci mogą wspierać Krajowy System Elektroenergetyczny. Działania administracji samorządowej dotyczące odpowiedniego kształtowania przestrzeni, promowania korzystania z fotowoltaiki z możliwością powszechnego dostępu do informacji, map potencjału solarnego, racjonalnego wykorzystania zasobów oraz tym samym dbałość o stan środowiska spowodować mogą, że miasto zwiększy swoje szanse na miano inteligentnego (z ang. Smart City), [Gotlib i Olszewski 2016]. 


\section{Bibliografia}

Bank Danych Lokalnych: Energia elektryczna w gospodarstwach domowych w miastach w 2018 roku, dane na dzień 04.11.2019 dla miasta Lubartów https://bdl.stat.gov.p1/BDL/dane/teryt/tablica [dostęp: 24.03.2020].

blog.poradnik-budowlany.com; https://blog.poradnik-budowlany.com/panele-fotowoltaiczne-czywarto-kupic-panele-fotowoltaiczne/ [dostęp: 24.03.2020].

GLOBEnergia, Ile kosztuje nas energia elektryczna? Ceny $1 \mathrm{kWh}$ na 20.09.2019; https://globenergia.pl/ile-kosztuje-nas-energia-elektryczna-aktualizujemy-ceny/ [dostęp: 26.03.2020].

Gotlib D., Olszewski R., 2016. Smart city, informacja przestrzenna w zarządzaniu inteligentnym miastem. PWN, Warszawa, 1-200.

Gużda A., Szmolke N., 2017. Analiza opłacalności zastosowania ogniw fotowoltaicznych w warsztacie naprawy autobusów. Autobusy: technika, eksploatacja, systemy transportowe 6 , $188-192$.

Hejmanowska B., 2006. Wspomaganie decyzji z wykorzystaniem narzędzi GIS - ryzyko związane z dokładnością danych źródłowych. Arch. Fotogram. Kartogr.Teledetekcji 16, 197-206.

Jurasz J., Krzywda M., Mikulik J., 2013. Wykorzystanie fotowoltaiki w warunkach solarnych miasta Krakowa - wstępne studium wykonalności dla budynku użyteczności publicznej - budynek wydziału uczelni wyższej. Napędy i Sterowanie 15, 12, 73-77.

Klugmann-Radziemska E., 2010. Fotowoltaika w teorii i praktyce. Legionowo (Poland). BTC, 1-200.

Kolendo Ł., Krawczyk D.A., 2016. Wykorzystanie GIS i danych klimatycznych do obliczeń potencjału solarnego możliwego do wykorzystania w systemach C.W.U. I C.O., Rynek Energii.

https://www.cire.pl/pliki/2/2016/10_krawczyk_wykorzystanie_gis_i_danych_klimatycznych_rec.pdf [dostęp: 24.03.2020]

Krawczyk A., Zawisza M., Zygmunt M., Żądło A., Zając M., 2018. Analiza potencjału ekspozycji słonecznej dachów o zróżnicowanej konstrukcji z uwzględnieniem zacienienia na przykładzie wybranych obiektów budowlanych z terenu miasta Nowy Sącz. Roczniki Geomatyki / Pol. Tow. Inform. Przestrz. 16, 2, 113-130.

Kronenberg J., Bergier T., 2010. Wyzwania zrównoważonego rozwoju w Polsce. Kraków, Fundacja Sendzimira, 1-351.

Mertens K.,2014. Photovlotaics: Fundamentals, Technology and Practice. Steinfurt (Germany), John Wiley\& Sons Ltd., 1-294.

Nawrot F., 2017. Budowa instalacji odnawialnych źródeł energii a planowanie przestrzenne Prawne Probl. Górn. Ochr. Środ. 1, 71-89.

Nowicki M., 2012. Nadchodzi era Słońca. PWN, Warszawa, 1-128.

Oszczak W., 2012. Kolektory słoneczne i fotoogniwa w Twoim domu. WKt, Warszawa, 1-144.

Pietras-Szewczyk M., 2014. Energetyka solarna oparta na źródłach rozproszonych w miastach. Zastosowanie narzędzi GIS w ocenie lokalnych warunków solarnych. Rynek Instalacyjny 9, 36-43.

Piskorski R., 2017. Analiza widoczności z wykorzystaniem lotniczego skaningu laserowego jako wskaźnik walorów krajobrazowych na przykładzie Kopca Kościuszki w Krakowie. Mazowsze Studia Regionalne, 55-66

Portal gov.pl - Serwis Rzeczypospolitej Polskiej: Skorzystaj z programu „Mój prąd” https://www.gov.pl/web/gov/skorzystaj-z-programu-moj-prad [dostęp: 24.03.2020].

Stilo Energy: Wymiary paneli fotowoltaicznych - jak je odpowiednio dobrać? Powierzchnia dachu, a instalacja fotowoltaiczna https://stiloenergy.pl/2019/05/08/wymiary-paneli-fotowoltaicznych-jakje-odpowiednio-dobrac/\#3 [dostęp: 26.03.2020].

Ustawa Prawo energetyczne z dnia 10 kwietnia 1997 r. Tekst ujednolicony w Departamencie Prawnym i Rozstrzygania Sporów URE, stan na dzień 29 lutego 2020 r. Dz.U. z 2019 r. poz. $755,730,1435,1495,1517,1520,1524,1556$ i 2166 oraz z 2020 r. poz. 284.

Załącznik do Uchwały Nr XV/82/2016 Rady Miasta Lubartów z dnia 22 marca 2016 roku, Plan Gospodarki Niskoemisyjnej dla miasta Lubartów. 